\title{
Apmaldījušies brīvībā: anomija mūsdienu Latvijā
}
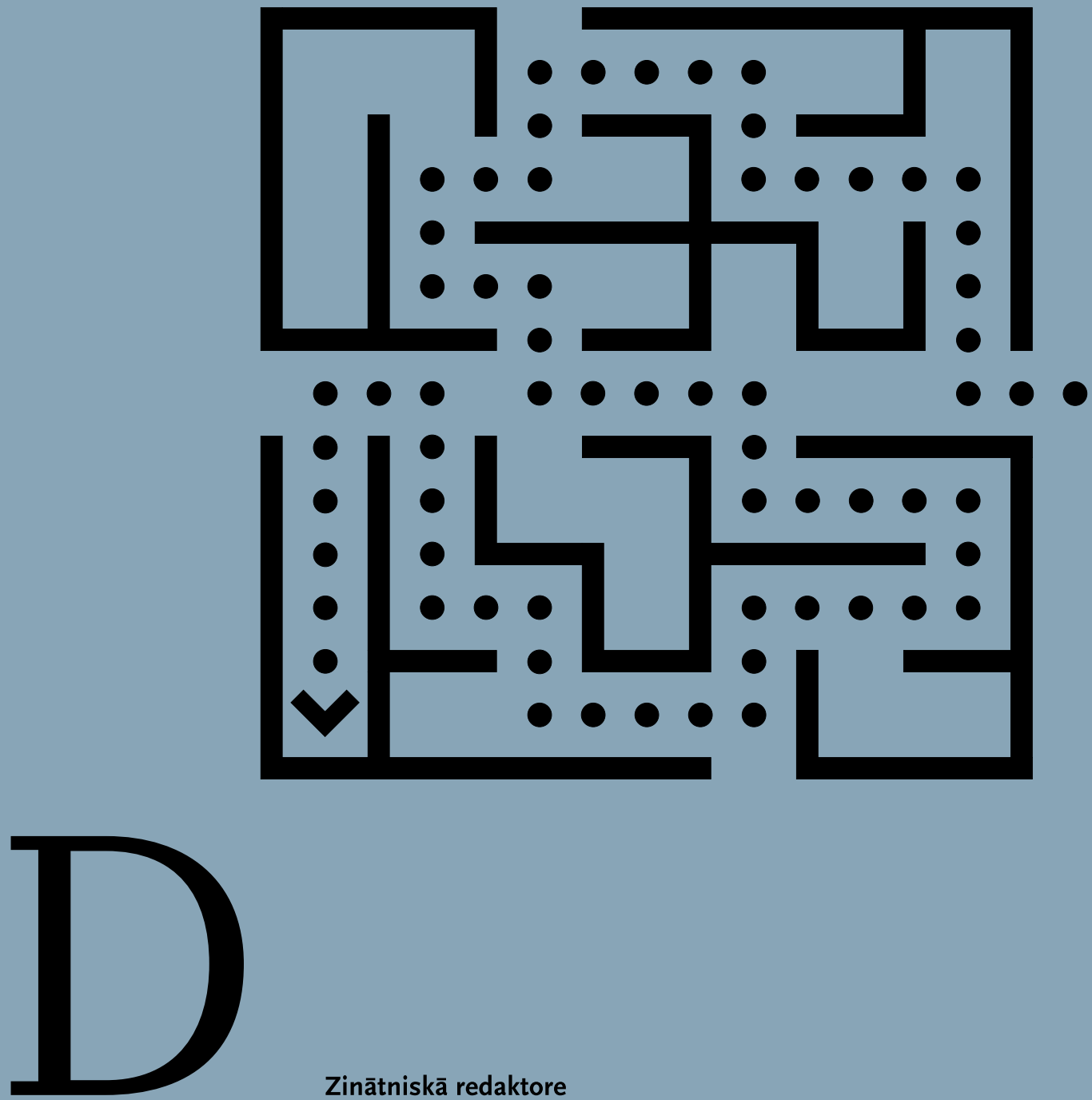

Zinātniskā redaktore

Dr. sc. soc. Aija Zobena 


\section{Apmaldījušies brīvībā:} anomija mūsdienu Latvijā

Zinātniskā redaktore Dr.sc. soc. Aija Zobena 
Aija Zobena (zin. red.). Apmaldỉjušies brīvỉbā: anomija mūsdienu Latvijā = Lost in Freedom: Anomy in Contemporary Latvia. Rīga: LU Akadēmiskais apgāds, 2018. 184 lpp.

RECENZENTI:

Dr. phil. soc. darbā Signe Dobelniece, Latvijas Lauksaimniecības universitāte Dr. sc. soc. Lïga Paula, Latvijas Lauksaimniecỉbas universitāte

Kolektīvā monogrāfija ir apstiprināta publicēšanai ar Latvijas Universitātes Sociālo zinātnuu fakultātes Sociālo un politisko pētijumu institūta zinātnes padomes sēdes lēmumu 09.04.2018. (protokola Nr. SZF-V15.5/4).

LITERĀRĀ REDAKTORE Ilze Jansone

KOREKTORE Gita Bērzina

Kolektīvā monogrāfija izstrādāta LU Sociālo zinātnu fakultātes Sociālo un politisko pētijumu institūtā ar valsts pētijumu programmas «Inovācij un ilgtspējīga attīstỉba: Latvijas pēckrīzes procesi globālā kontekstā»

(SUSTINNO) finansiālu atbalstu.

\section{SUSTINNO LaTVIJAS}

SATURS

\section{PRIEKŠVĀRDS}

AGITA MISĀNE Anomijas tēma un teorijas sociālajās zinātnēs

VISVALDIS VALtenBergs Globālo vērtību orientācija Latvijas iedzivotāju vidū

3 INTA MIERIN Politiskāa atsvešinātība un anomija mūsdienu Latvijā

$4 \quad$ J̄̄NIS IKSTENS Ar balsi vien? Mediju patērina, vērtīborientāciju un valdības darbības vērtējuma ietekme uz Latvijas iedzivotāju attieksmēm pret valsts drošỉbu

5 ZANE VĀRPINA Anomija demogrāfijas kontekstā. Anomijas un sociālo faktoru ietekme uz reproduktivijiem nodomiem un to realizāciju

6 VITA ZELČE Anomija Latvijas svētku un piemiṇas dienu kalendārā un praksē

\section{IZMANTOTIE AVOT|}

AUTOR I

ENGLISH SUMMARY

AUTHORS

ISBN 978-9934-18-308-9 
Kolektīvā monogrāfija «APMALDİJUŠIES BRĪVīBĀ: ANOMIJA MŪSDIENU LATVIJĀ» (zinātniskā redaktore Aija Zobena), kas iznāk sērijā «Inovācijas un ilgtspējīga attīstība Latvijā» apkopo valsts pētijumu programmas «Inovācija un ilgtspējiga attīstība: Latvijas pēckrīzes procesi globālā kontekstā» (SUSTINNO) ietvaros îstenotā pētijumu projekta «Sabiedrības vērtīborientācijas un sabiedrības atjaunošanās» galvenās atziņas. Šis projekts tika istenots Latvijas Universitātes Sociālo zinātnu fakultātes Sociālo un politisko pētỉjumu institūtā laikā no 2014. līdz 2018. gadam. Šì projekta mērkiis bija pētīt Latvijas sabiedrības vērtīborientācijas un normas, lai izprastu plašsaziņas lỉdzekḷu un padomju režima ietekmi uz to genenēzi un noteiktu anomijas izplatību sabiedrībā, kas tālāk lautu analizēt šo vērtīborientāciju ietekmi uz sociālo izturēšanos, t. sk. uz lïdzdalības formām sabiedrỉbas dzivēe (ipaši jauniešu vidū), ğimenes modeḷu evolūciju un reproduktīvo uzvedību.

Jebkurā gadijjumā anomija ir ārkārtējs, nenormāls stāvoklis, kas rodas, vājinoties indivìda un plašākas kopienas sociālajām saitēm un tādējādi arī viṇa identifikācijai ar kopienas vērtībām. Anomijas risks pārejas sabiedrībās, arī Latvijā, vienmēr ir objektīvi augstāks. Daḷa veco sociālo institūciju ir likvidētas, to vietā radušās jaunas, kas vēl nav paspējušas iegūt pietiekami spēcīgu autoritāti. Sabiedrības locekḷiem nākas konstruēt jaunas identitātes. Daḷa sociālo normu vairs nedarbojas. Pie klasiskiem izaicinājumiem var minēt arī pilsonības statusa mainu, piemērošanos citai valsts valodai un ekonomiskajai sistēmai, naudas, īpašumu struktūras, izglìīibas vai pensiju sistēmas reformas. Pat daudzus gadus pēc neatkarības atgūšanas un zināmā mērā saistībā ar pārmainu procesiem sabiedrībā Latvijā vērojams aug̣st sabiedrības atsvešinātības līmenis, kā arī ārkārtīgi izteikta politiskā atsvešinātība. Anomiju Latvijā veido vairākas dimensijas, kas nedaudz atšḳiras un tomēr ir cieši saistìtas ar literatūrā (Markss, Dirkems u.c.) minētajām: bezspēcība, atsvešinātība no sevis, normu trūkums, kultūras atsvešinātība un izolētỉba, skaidras pārliecības trūkums, ilgtermina mērḳu un vĩzijas trūkums, atsvešinātība no ǵimenes, atbildības. Bezspēcība un atsvešinātība no sevis ir izteiktākās anomijas dimensijas, kam seko normu un skaidras pārliecības trūkums. Tieši normu, skaidras pārliecības, kā arī ilgtermina mērku un vīzijas trūkumu var uzskatìt par visproblemātiskākajiem Latvijas sabiedrību raksturojošiem aspektiem. Tie ỉpaši raksturīgi trūcīgākajiem sabiedriba slāniem. Lìdztekus nelatviešiem trūcịgākie iedzivotāji biežāk izjūt arī bezspēcību un atsvešinātību no sevis. Politiskā un sociālā atsvešinātība, lai ga tās ir saistìtas ar anomiju, īpaši ar skaidras pārliecības trūkumu, veido atškịirïgus kognitivos konceptus (tâtad politisko neiesaistišanos un sociālo saišu vājumu, sabiedrības sociālo fragmentētỉbu nevar uzskatìt par tiešu anomijas pazimi). Interesanti, ka jaunieši jūtas sociāli un kulturāli atsvešinātāki, turpretī vecāki cilvēki-politiski atsvešinātāki. 
Monogrāfijas pirmajā nodaḷā «ANOMIJAS TĒMA UN TEORIJAS SOCIĀLAJĀS ZINĀTNĒS» AGITA MISĀNE iepazistina ar anomijas jēdzienu un tā attīstību sociālajās zinātnēs kopš 19. gadsimta pēdējiem gadiem līdz pat 21. gadsimta sākumam. Anomiju pienemts uzskatit par klasisku socioloğijas tēmu. Tās izvērstas interpretācijas atrodamas jau socioloğijas pamatlicēja Emīla Dirkema (Émile Durkheim) darbos, īpaši viṇa doktora disertācijā «Darba dalī̌̌ana sabiedrībā» (De la division du travail social, 1893) un «Pašnāvība» (Le Suicide, 1897). Pats anomijas jēdziens un tā interpretācija, ka anomie ir situācija, kuras raksturs meklējams indivìda un sociālo institūciju attiecībās, kḷuva par vienu no nozīmīgākajām tēmām Dirkema sociolog̣ijā. Pēdējās desmitgadēs ir radies lielāks skaits pētijumu par anomiju teritoriāli, konkrētās sabiedrībās, intensīvi tiek pētìta anomija konkrētu organizāciju vai sociālo grupu kontekstos, kā arī méğinot sintezēt iepriekšminētos specifiskos pētījumus ar jaunu teorētisku piedāvājumu, kas meklē anomijas indikatorus ārpus individuālās anomijas pazīmēm.

Nākamajā nodaḷā «GLOBĀLO VĒRTİBU ORIENTĀCIJA LATVIJAS IEDZīVOTĀJU VIDŪ» VISVALDIS VALTENBERGS norāda, ka ilgtspējības sociālā un psiholoğiskā dimensija ir nozimmīgs globalizācijas procesu izpratnes komponents. Visās valstīs sabiedrības grupas atšķiras pēc globalizācijas procesu sniegto iespēju izmantošanas. Dažas grupas labprāt noslēgtos no globalizācijas ietekmes, citas vēlētos pilnīgāk izmantot globalizācijas sniegtās iespējas darba tirgū, tirdzniecībā, zināšanu apmaināa un daudzās citās jomās. Sabiedrỉbas vērtỉbu fonam ir liela nozìme ar starptautisko dimensiju saistìtu rīcỉbpolitiku ieviešanā. Pētijjuma secinājumi, kas tapuši, balstoties uz Starptautiskās sociālās aptaujas programmas (ISSP) un valsts pētijumu programmas SUSTINNO projekta «Sabiedrības vērtīborientācijas un sabiedrības atjaunošanās» ietvaros veikto aptauju rezultātiem, liecina, ka vērtības un attieksme ir diezgan vāji subjektīvās globālās orientācijas skaidrotājfaktori (ISSP Research Group, 1998, 2012, 2015; SUSTINNO, 2015). Demogrāfiskie faktori, jo ipaši ienākumi un izglìtība, vairāk ietekmē respondentu intereses izjūtu un identifikāciju ar pasaules dalāam ārpus nacionālās valsts robežām. Iedzīvotāju vērtībām un attieksmei ir lielāka nozīme, skaidrojot iedzīvotāju interesi par notikumiem konkrētos reǵionos. Pētijums apliecina, ka respondenti ar izteiktākām tradicionālām vērtībām izrāda lielāku interesi par notikumiem tieši savā reğionā. Taču respondenti ar izteiktām universālisma vērtībām izrāda lielāku interesi par notikumiem ne tikai savā pilsētā, pilsētas rajonā, Krievijā, bet arì citos pasaules reǵionos.

Trešajā monogrāfijas nodalā «PoLITISKĀ ATSVEŠINĀTİBA UN ANOMIJA MŪSDIENU LATVIJĀ» INTA MIERIṆA pievēršas politiskās anomijas Latvijas sabiedrībā izpētei. Gadsimta ceturksni pēc neatkarības atgūšanas Latviju joprojām raksturo Eiropas mērogam augsts korupcijas un nepotisma līmenis, savukārt pilsoniskās sabiedrības attīstību kavē iedzīvotāju politiskais cinisms, apātija un neuzticēšanās valdỉbai. Lìdzšinējie pētijumi liecina, ka vienlaikus vērojami augsti sociālās atstumtỉbas riski, sociālā fragmentētība, sociālās uzticēšanās un savstarpējas empātijas trūkums. Daži zinātnieki uzskata šo situāciju par komunistiskā režima mantojumu, bet citi norāda uz pārejas procesa negatīvo ietekmi. Autore piedāvā «postmodernā stāvokḷa» Latvijā sociālo diagnozi, izmantojot klasiskos atsvešinātības un anomijas jēdzienus. Socioloğiskais ietvars ḷaj aplūkot pagātnes mantojuma pārvarēšanas grūtības plašākā vērtību un iekšējo normu kontekstā.

Politiskās anomijas izpēti ceturtajā monogrāfijas nodạ̣ā «AR BALSI VIEN? MEdIJU PATĒRIN,A, VĒRTİBORIENTĀCIJU UN VALDİBAS DARBī BAS VĒRTẼJUMA IETEKME UZ LATVIJAS IEDZİVOTĀJU ATTIEKSMĒM PRET VALSTS DROŠīBU» turpina JĀNIS IKSTENS, pievēršoties izpētes jautājumam, cik plašu rezonansi Latvijas sabiedrībā guvuši vēstijumi, kurus Krievija aktī vi komunicē savā propagandā pret Latviju. Kādi faktori sekmē (vai kavē) uznēmību pret Krievijas propagandas vēstījumiem? Šajā analīzē ieklauti arī tādi neatkarīgie mainīgie kā indivìda vērtīborientācijas, sociāli demogrāfiskie parametri un uzskati par valdỉbas darbu. Iepriekš veiktie pētijumi vedina uzskatīt, ka ikkatrai no šo neatkarīgo mainīgo grupām ir noteikta ietekme uz indivīdu politiskajiem uzskatiem. Autors izvirza pieñēmumu, ka plašsaziṇas līdzekḷu patēriṇa ieradumi visvairāk ietekmē uzṇēmību pret Krievijas propagandas vēstìjumos iekodētajām attieksmēm.

ZANE VĀRPINA piektajā monogrāfijas nodalā «ANOMIJAS UN SOCIĀLO FAKTORU IETEKME UZ REPRODUKTİVAJIEM NODOMIEM UN TO REALIZĀCıJU» pievēršas izpētei, kā sociālās un ekonomiskās pārmainas ir mainījušas reproduktīvo lēmumu pienemšanu Latvijā, kur summārais dzimstības koeficients joprojām nesasniedz nosacìto tautas atražošanās koeficientu $(2,1)$ Demogrāfiskajā literatūrā starp trīs svarīgākajiem teorētiskajiem skaidrojumiem, kāpēc Centrāleiropas un Austrumeiropas valstīs, tai skaitā Latvijā pēc neatkarïbas atjaunošanas, ir samazinājusies dzimstỉba, ir minēta ekonomiskā nedrošība, demogrāfiskā pāreja un sabiedrības anomija. Tomēr visiem šiem skaidrojumiem joprojām nav mikrolìmeṇa empīisku pierādījumu. Pētijumos, piemēram, nav konstatēta tieša saistība starp bērnu skaitu g̛̣imenē, ekonomisko stāvokli, nodarbinātỉbu vai ienākumu līmeni. Nepietiekam izpētìta ir sakarība starp izmainām sabiedrības vērtību sistēmā un dzimstību. Vēl mazāk demogrāiskie pētijumi lĩdz šim pievērsušies anomijas ietekmei uz demogrāfisko uzvedību.

Monogrāfiju noslēdz nodą̧a «ANOMIJA LATVIJAS SVĒTKU UN PIEMINAS DIENU KALENDĀRĀ UN PRAKSĒ», kurā VITA ZELČE, izmantojot Emīla Dirkema anomijas koncepciju, sniedz Latvijas svētku, atceres un atzīmējamo dienu valsts kalendāra, svētku svinēšanas un komemoratīvo prakšu iztirzājumu. Tas ir balstìts uz LU Sociālo zinātṇu fakultātes pasūtito socioloğisko aptauju rezultātu un svētku un pieminas dienu rituālu analīzi. 
Aplūkojot četras svētku, atceres un atzīmējamo dienu grupas -1) valsts un patriotiskie svētki, 2) komunistiskā un nacistiskā totalitārā režìma upuru piemiñas dienas, 3) no padomju režìma mantotie svētki un 4) spriedzes menedžmenta svētki-, autore secina, ka Latvijas svētku, atceres un atzìmejjamo dienu kultūras atseviškās jomās ir vērojama anomija, kas vēsta par pretrunām starp pastāvošo dzīveskārtību un sociālo grupu un indivīdu identitātēm un vērtībām.

\section{Pateicības}

Kolektīvās monogrāfijas autori izsaka pateicību visiem, kuri veicināja šì darba tapšanu. İpaši pateicamies profesoram Jānim Ikstenam, valsts pētijumu programmas «Inovācija un ilgtspējiga attistỉba: Latvijas pēckrīzes procesi globālā kontekstā» (SUSTINNO) un projekta «Sabiedrïbas vērtïborientācijas un sabiedrības atjaunošanās» vadītājam laika posmā no 2014. līdz 2017. gadam, par radošo ieguldỉjumu programmas veidošanā, realizēšanā un šì darba ieceres tapšanā. Par palīdzību tulkošanas darbā pateicamies Zanei Vārpiṇai.

Dr. sc. soc. Aija Zobena

zinātniskā redaktore 


\section{Anomijas tēma un teorijas sociālajās zinātnēs}

Anomijas jēdziens un tā agrīnās izpratnes

pretācijas atrodamas jau sociolợijas pamatlicēja Emìla Dirkema (Émile Durkheim, 1858-1917) darbos, îpaši vina doktora disertācijā «Darba dalīšana sabiedrībā» (De la division du travail social, 1893) un «Pašnāvība» (Le Suicide, 1897). Tomēr pats jēdziens ir krietni senāks. Mūsdienu sociālo zinātnu pētijumos pārsvarā tiek lietotas franču (anomie) vai anglu (anomy) transkripcijas, kas abos gadijjumos atsaucas uz griek̦u jēdzienu «ávouia

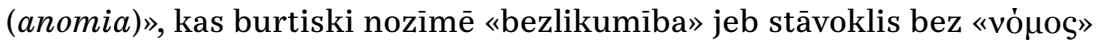
(nomos) - likuma regulētas kārtības. Agrākie nomos lietojumi mūsdienu izpratnē datējami ar 2o. gadsimta 3o. gadiem un atrodami vācu politikas un tiesību filozofa (un vienlaikus - Trešā Reiha ietekmīgākā jurista) Karla Šmita (Carl Schmitt, 1888-1985) darbos. Izvērstāk šo konceptu Šmits attīstija vēlāk (Schmit, 1950), ar «Zemes Nomoss» apzīmējot ideoloğiski pamatotu politisku sistēmu, kuru raksturo transcendentas pasaules kārtības (Ordnunğ) un tās lokalizācijas (Ortnung) vienỉba.

Rūpīgs ieskats ideju vēsturē (plašāk skat. Orrù, 1987) atklāj gan dzīigigās sengrieḳu domātāju debates par anomijas kā sabiedrības stāvokḷa raksturu, gan arī Vecajā un Jaunajā Derībā atrodamos priekšstatus. Jebkurā gadījumā anomija nav stāvoklis, ko sociālo procesu novērotāji būtu atklājuši nesen.

Anomijas kā nopietna sociāla bojājuma novērtējums atrodams jau Bībeles pirmajās grāmatās. Kristiešu tekstos un līdz ar to Eiropas vēsturē tās nonāca, pateicoties grieķu tulkojumam jeb Septuagintai, kur anomijas jēdziens tiek lietots ap trīssimt reižu, visvairāk Psalmu grāmatā (Orrù, 1987, p. 43). Faktiski visur anomijas jēdziens izmantots, lai raksturotu traǵisku, bīstamu vai mokošu sabiedrības vai personas stāvokli. Tā, piemēram, pirms neglābjami samaitātās un tāpēc bojāejai nolemtās Sodomas iznīcināšanas engóelis aicina taisnprātīgo Latu glābties, lai tas neaizietu bojā Sodomas anomiais dēḷ. Jaunais latviešu Bībeles tulkojums šajā vietā lieto vārdu «vaina», kas škiet neadekvāti, ievērojot notikušā dramatismu: “[..] ka netiec aizrauts šìs pilsētas vainas dẹ!!’ (Genesis 19:15). Bieži Vecajā Derībā anomia tiek lietots kombinācijā ar «ávouia (hamartia)», ko latviešu valodā pieṇemts tulkot kā «grēks», turklāt abi stāvokḷi var piemist gan personai, gan sabiedrībai kopumā, t.i., jau Vecās Derības interpretācijā anomijai ir gan individuāls, gan kolektīvs raksturs. Latīnu Bībeles tulkojumā jeb Vulgātā anomia konsekventi tulkots kā iniquitas, kamēr hamartia kā peccatum, tie acìm redzami ir atškiriigi stāvokli. Attīstoties gan jūdaismam, gan kristietībai, to intelektuālajās tradīcijās nostiprinājās grēka un anomijas jēdziena aizvien konsekventāks nošķīrums - tas būtu jāpatur prātā, domājot par anomiju socioloǵiski šodien. «Anomija» kluva par saturiski plašāku un sociāli piesātinātāku jēdzienu nekā «grēks». Latīnu baznīcas tēvs Hieronīms rakstijja, ka iniquitas 
nozīmē atrasties ārpus likuma/likumïbas, kamēr peccatum notiek «pēc likuma»-t.i., tas ir jau pazīstama baušla pārkāpums (Orrù, 1987, p. 44). Citiem vārdiem, anomija ir gan sarežg̀itāāks, gan grūtāk aprakstāms stāvoklis nekā vienkārši kāda likumu pārkāpšana vai ignorēšana.

Sengrieķu pasaulē anomia sākotnēji nozīmēja individuālu stāvokliindivìda asociālu uzvedību (Ostwald, 1969, p. 85), turklāt jēdziens tika lietots gandrīz tikai kā īpašìbas vārds - anomos. Par anomisku tika uzskatìta necilvēcīga, netaisna un bezdieviga (dievu gribai nepakḷāviga) rīcība. Kā anomiski varēja tikt raksturoti arī likumi, apstākḷi, atsevišḳas emocijas, piemēram, dusmas, cilvēku iegribas, ja tiem piemita trīs iepriekš minētās pazìmes. Priekšstats par kolektīvu anomiju kā sociālpolitisku stāvokli attīstijās aptuveni 5. gadsimtā p.m.è. Par to, ka anomiju sāka interpretēt kā bezlikumību, škiiet, jāpateicas par vēstures tēvu dēvētajam sengrieḳu vēsturniekam Hērodotam. Rakstot par Mēdijas valsti savā darbā «Vēsture», Hērodots norādijja, ka Mēdijā gan eksistēja paražas un likumi, taču tie netika ievēroti praksēe, un tāpēc mēdieši sāka dzīvot, it kā to nemaz nebūtu. Vēlāk šādu interpretāciju pārṇēma citi vēsturnieki un arī dramaturgi (plašāk skat.: Orrù 1987, pp.19-21). Grieķu sabiedriskajā domā iezīmējās divas izplatītākās pieejas izpratnē par anomiju un problēmas risinājumā. Vieni uzskatijja anomiju par visa ḷaunuma un nemiera cēloni transcendentā līmenī, citi-par cilvēka un/vai visas sabiedrības raksturlielumu noteiktos vēstures laikmetu griežos (mūsdienās tās sauktu par pārejas vai pārmaiṇu sabiedrībām), kad anomiskas tendences sabiedrībā ir neizbēgamas, taču šai situācijai var atrast saprātīgus risinājumus. Uz šīm grieḳu diskusijām vēlāk atsaucās Karls Popers «Atvērtas sabiedrības un tās ienaidnieku» I dalā (Popper, 1998, skat. arī Orrù, 1987; Ostwald, 1969) Pārskatot visai plašo anomijai veltīto socioloğisko literatūru, jākonstatē, ka jaunais patiesi ir labi aizmirsts vecais - arī pēdējos simt gados var izškirirt šis pašas divas pieejas.

\section{Sociologijas klasiḳis un vina mazāk zināmie priekšteč} Gijo un Dirkems par anomie

No visiem autoriem, ko šodien dēvējam ar sociologíijas klasikiem, anomija visvairāk saistita ar Emila Dirkema vārdu. Ietekmes, kas vinam lika izmantot šo jēdzienu sava laika sociālās realitātes analīzei, jau sākot ar savu doktora disertāciju, varēja nākt no vairākiem avotiem. Pirmkārt, Emīls Dirkems uzauga vairāku paaudžu rabīnu ğimenē un, lai arī neturpināja ğimenē ierasto karjeru, labi pārzināja Vecās Derības un rabīniskās teoloğijas tradīciju. Kā rakstijja viens no vina biogrāfiem, Dirkems mēdzis atkārtot kolēǵiem: «Es galu galā esmu rabīna dēls!» (Alpert, 1939, p. 15) Priekšstats par cilvēka duālo dabu, kurā cīnās tieksmes uz labo un launo, novērojumi, ka cilvēks bieži alkatīgi iekāro to, kas viṇam pēc taisnības nemaz nepienākas, ir tipiski abrahāmisko reliǵiju eshatoloǵijai un arī būtiski Dirkema anomijas interpretācijas izpratnei (skat. Dirkema darbu «Par cilvēka dabas duālismu un tã sociālo stāvokli» (Volf, 1960, pp. 325-340)). Kā Dirkema anomijas izpratnes kontekstā rakstija Džons Hortons: «Dirkema cilvēks ir homo duplex, pa dalai egoistisks, anarhisks un pašvērsts, pa daḷai morāls, ciktāl vinu spēj regulēt un ierobežot sabiedrỉba, kura ir visas loğikas un morāles avots.» (Horton, 1964, p. 290) Arī Dirkema biogrāfs Stīvens Lūks atzīmē, ka Dirkema socioloğijā individuālais un sociālais ir dihotomiski (Lukes, 1971). Sabiedrības kopīgajās interesēs ir uzturēt kārtìbu, morāli, sakralitāti un normativitāti, kamēr individuālais cilvēks ir profāns un ḷaunprātīgs, un tikai sociālie ierobežojumi nẹ̦auj šīm negatĩvajām iezīmēm pilnībā izpausties.

Otrkārt, pēc pārcelšanās uz Parīzi, atšḳirībā no dzimtās provinciālās Epinālas un arī Bordo, kur sākās Dirkema zinātnieka karjera, vinǔ daudz skaidrāk varēja novērot visas kapitālisma straujās attīstības negatīvās blakusparādības, kas pavadijja mehāniskās solidaritātes transformāciju organiskajā solidaritātē, - tā bija viena no Dirkema disertācijas pamattēmām. Lielpilsētas bija industrializācijas avangards, bet arī vietas, kur varēja sastapt bezpajumtniekus, sairušas ğimenes, alkoholiķus, prostitūtas - jebko, kas personificēja «sabiedrības vātis». Tas lika vinam jautāt: kur meklējami šo sociālo patoloǵiju cēloṇi? Laika gaitā viṇš nonāca pie atbildes, ka tie meklējami gan sociālo normu trūkumā vai to nepietiekamā piemērošanā, gan arī pārmērīgā regulējumā, kas ceḷas piespiestas darba dalī̌̌nas rezultātā.

Treškārt, ir vēl kāds avots, ar ko var saistìt Dirkema pievēršanos anomijas tēmai. Lielākā dạ̦a Dirkema komentētāju apgalvo, ka pirmo reizi jēdzienu «anomija» Dirkems izmanto savā disertācijā «Darba dalīšana sabiedrībā» (De la division du travail social) 1893. gadā. Tomēr vinš ar to saskārās jau sešus gadus agrāk, kad žurnālā Revue philosophique publicēja recenziju par morālfilozofa Žana Marī Gijo (Jean-Marie Guyau, 1854-1888) grāmatu «Nākotnes nereliğija» (Irréligion de l'avenir). Uz Dirkema saikni ar Gijo norāda Antonijs Gidenss (Giddens, 1971, p. 80) un daži citi autori (piemēram, Levine, 1985, p. 61). Gijo izceḷas anomijas interpretu vidū ar to, ka vērtēja anomiju pozitīvi. Anomijai Gijo bija pievērsies jau savos agrākajos darbos, bet jo îpaši darbā «Nākotnes nereliğija» iezīmējās viṇa uzskats, ka anomija nākotnē būs neatkarīgas morālas personības pazìme. Pēc revolūcijas Francijā, sabiedrības sekularizācijas un laicite klātbūtnē, reliğijas nākotnes tēma nodarbināja ne vienu vien domātāju. Aizrautīgi tika piedāvātas dažādas «nākotnes reliğijas» versijas. Pazisstamākā no tām ir Ogista Konta «humanitātes religóija». Konts ne tikai iztēlojas nākotnes garīgās attīstības virzienu, bet arī piedāvā detalizētu prakšu sistēmu un kalendāra reformu, kam būtu jāaizstāj pazistamās reliǵiju formas. Gijo pārspriedumi bija tikai teorētiski. Viña grāmata sniedza sociālu skatijumu uz reliǵiju vēstures gaitu un reliğisko parādỉbu izcelsmi. Reliğiju izcelsmes pamatā, pēc Gijo domām, bija cilvēku sociālās vajadzības pēc biedrošanās un pozitīvām emocijām, ko cilvēkam var sniegt tikai attiecības 
ar citiem cilvēkiem. Tã izveidojas trīs religóijas pamata pazīmes - mìtu sistēma, ticības apliecinošā forma jeb dogmatika (t.i., ko šīs relióijijas māca) un kults jeb rituālu sistēma. Tālāk, kā Gijo uzskatijja, minētās pazimes 19. gadsimta laikā izzūd un cilvēce tuvojas reliǵiju norietam. Reliǵijas tiks nomainìtas ar jaunu pasaules uzskatu, kura pamatiezīme būs «reliǵiskā anomija». Mìtus un kultu aizstās empīiski novērojumi un zinātnisks pasaules izskaidrojums, bet dogmas - brivva, religiijas uzspiestu normu un likumu un apstākḷu nesaistìta, skeptiska, vērtējoša attieksme pret visu, kas būs jaunās morāles pamatā. To tad Gijo sauc par reliǵisko anomiju (Guyau, 1887/1912).

Dirkems pozitīivi novērtēja Gijo pieeju - meklēt reliǵiju saknes cilvēces sociālajā attīstībā, taču bija visnotal kritisks attiecībā uz anomijas novērtējumu. Savā recenzijā viṇš rakstīja, ka brīvā, emancipētā cilvēka intelektuālās aktivitātes aug̣̣i nevar aizstāt reliǵijas. Katrs cilvēks gan var nonākt pie savām individuālām atzinām, bet tas cilvēkus tikai attālinās citu no cita, apgrūtinās to apvienošanās iespējas, savukārt tieši biedrošanās vajadzībā pats Gijo bija saskatijis reliǵiju izcelsmes un izdzìvošanas pamatu (Durkheim, 1887; Pickering, 1994).

Pats anomijas jēdziens un tā interpretācija, ka anomie ir situācija, kuras raksturs meklējams indivīda un sociālo institūciju attiecībās, kḷuva par vienu no nozīmīgākajām tēmām Dirkema socioloǵijā. Dirkema uzskati par anomiju tika vairākkārt precizēti un papildināti (par Dirkema uzskatu evolūciju skat.: Olsen, 1965; Marks, 1974; Besnard, 1982; Orrù, 1987, pp.104-114). Plaši raksturojot, Dirkems lieto terminu anomie, lai aprakstītu tādu sabiedrības stāvokli, kad sociālās institūcijas dažādu iemeslu dēl nespēj nodrošināt visas sabiedrības morālu vadību, un tāpēc sabiedrības normas un sociālā kontrole nesakṇojas vai ir vāji iesakṇotas sociālajā sistēmā. Izsakoties vienkāršiem vārdiem - tas ir tad, kad cilvēks nezina, kas ir labs un launs, savukārt sabiedrības institūcijas nespēj vinam to paskaidrot. Tādos apstākḷos ir pamats apšaubìt arī sociālo institūciju leğitimitāti kopumā.

Darba dalǐšanā anomija parādīta kā sabiedrības funkcionāla problēma, kamēr darbā «Pašnāvība» Dirkems anomiju raksturo kā cilvēka normatīvās integrācijas defektu. Divi objektīvie cēloṇi, kādēl rodas individuālo un kolektìvo mērḳu nesakritība, ko identificē Dirkems «Darba dalǐšanas» trešajā dạ̦ā, ir straujas sociālās izmainas un darba dalīšana kapitālistiskajā sabiedrībā, pārejot no sabiedrības mehāniskās solidaritātes uz organisko solidaritāti. Cilvēku profesionālā specializācija - kapitālistiskās darba dalīšanas rezultāts - gan ḷauj vairāk saražot un tādējādi straujāk attīstīt ekonomiku, bet arī attālina cilvēku no sabiedrības kopumā, padarot vinu par konkrētas operācijas veicēju, kas neatbild par sociālajiem procesiem kopumā. Cilvēks var kḷūt bagātāks, bet ne laimīgāks.

Dirkema ieskatā, ja vien cilvēkam ḷautu valu, viṇa savtīgã daba izpaustos pilnā mērā. Tikai sociālā kontrole viṇam to neḷauj. Funkcionāli veselā sabiedrībā cilvēks apzinās savu sociālo atbildỉbu un lỉdz ar to arì ierobežotību un laujas sabiedrības kontrolei. Parasti tā tiek ìstenota ar sociālo institūciju starpniecību. Cilvēkam nākas samērot savu individuālo gribu ar sabiedrības kopịgajām vērtībām, sociālām normām un sociālo kultūru. Tomēr ir situācijas, kad sociālās kontroles instrumenti nedarbojas. Turklāt, vājinoties indivīda un kopienas sociālajām saitēm, vājinās arī viņa identifikācija ar kopienas vērtỉbām. Tajā pašā laikā darba dališanas dēḷ sabiedrība kopumā kḷūst ne vien fragmentētāka, bet arī ievērojami sarežğìtāka. Jo sarežğìtāka ir sabiedrība, jo vairāk tai ir vajadzīgs arī ētisks pašregulējums, jo visas situācijas nav iespējams un nekad arī nebūs iespējams paredzēt likumā.

Darbā «Pašnāvība» Dirkems iezīmē «sociālās normas» atrašanos divu vektoru jeb asu krustojuma laukā. Viens ir normatīvā regulējuma vektors, otrs - solidaritātes vektors. Ja raugāmies uz normatīvā regulējuma asi, tad norma atrodama starp anomiju («bezlikumibu») un fatālismu jeb pilnīgu, nekritisku pakḷaušanos ārējam regulējumam. Uz solidaritātes ass tā atrodas starp pilnịgu solidaritātes trūkumu (egoismu) un altruismu, indivìda pilnīgu ziedošanos citu labā. Šajā pašā darbā Dirkems izšķīra hronisko un akūto jeb krīzes anomiju. Hroniskā anomija ir ilgsstoši nepārejošs stāvoklis, kas izpaužas vairākās sociālās dzīves sfērās, piemēram, ekonomikā un g̛imenē. Akūta anomija rodas sociālu satricinājumu laikā. Saskaṇā ar Dirkema aplēsēm pašnāvību skaits krīzes anomiju laikā ir lielāks.

Anomijas risks pārejas sabiedrībās vienmēr ir augstāks. Dirkems rakstijja par sava laika - 19. gadsimta beigu - sociālajām pārmaiṇām Francijā. Rūpniecība un kapitālistiskās attiecības attīstijjās ātrāk nekā sociālās kontroles institūcijas. Anomijas pazīmes, ko novēroja Dirkems, bija alkatība, neierobežotas ambīcijas, patērniecība un hēdonisms (skat. Lukes, 1970, pp. 89-90). Taču nav grūti ievērot, ka minētās parādības var novērot arī nesenākā vēsturē - citās pārmainu sabiedrībās. Dala sociālo institūciju tajās ir beigušas pastāvēt, to vietā var būt radušās jaunas, kas vēl nav paspējušas iegūt pietiekami spēcīgu autoritāti; jauni sociālās kontroles instrumenti nav vēl izstrādāti. Arī daḷa sociālo normu vairs nedarbojas. Daudz kas no tā, uz ko cilvēks varēja palauties iepriekš, ir sabrucis, un vinam nav skaidrs, uz ko lai tagad palaujas un kam lai uzticas. Šādos apstākḷos ḷoti zemie uzticības rādītāji tādām institūcijām kā parlaments, valdība, tiesa un vēl citām, kuras saistītas ar sociālo kontroli, ir visai skaidra anomijas liecība. Pārmainu sabiedrībās mainās arī identitāšu raksturs, piemēram, var minēt pilsonības statusa mainuu, mainìtu vietu sociālajā hierarhijā, nepieciešamību piemēroties kādai citai valsts valodai un ekonomiskajai sistēmai, naudas reformas un iepriekšējo ipašumu un uzkrājumu zaudējumus. To pārdzīvoja, piemēram, daudzi bijušie PSRS pilsoṇi un turpina piedzīvot politiskie un ekonomiskie migranti arī mūsdienās.

Dirkema anomijas teorija pieder socioloğijas klasikai, par anomiju nav iespējams rakstīt, neatsaucoties uz Dirkemu. Tomēr tā ir maz piemērota 
operacionalizācijai empīriskā pētỉjumā. Citiem vārdiem, tā labi der aprakstam, bet praktiski neder anomijas līmeṇa mērijumiem. Savukārt anomijas pētijjumi mūsdienās ir gandrīz tikai empīriski orientēti. Dirkema pēcteči mēğināja minēto trūkumu novērst, kā redzēsim, ar mainīgām sekmēm.

\section{Roberta Mērtona}

spriedzes teorija

Robertu Mērtonu var uzskatīt par Dirkema tradīcijas turpinātāju. Pateicoties vina darbiem, anomijas jēedziens nostiprinājās angliski rakstìtajā sociolog̣iskajā literatūrā un par anomijas pētniecības centru kluva ASV. Dirkema anomijas teoriju jau agrāk bija ievērojuši, novērtējuši un komentējuši Talkots Pārsons (Parsons, 1937) un Eltons Maijo (Mayo, 1933), taču Mērtona nelielā apjoma raksts «Sociālā struktūra un anomija» (Merton, 1938) un vēlākā atgriešanās pie anomijas tēmas citos darbos (Merton, 1964, 1968) noteikti ir visietekmīgākā. Lìdzīgi kā Dirkems, arī Mērtons rakstijja par savu laiku un sociālo vidi (ASv pēc Lielās depresijas un tūlìt pēc Otrā pasaules kara), taču izdarija vispārinātus secinājumus. Dirkema interešu fokusā bija darba dalīšana un tās plašās sociālās sekas, turpretī Roberta Mērtona uzmanību saistīja attiecības starp sabiedrības institucionalizētajiem mērķiem un sociāli pieņemamajiem līdzekḷiem to sasniegšanai (Merton, 1938). Ar anomijas tēmas «pārcelšanos» uz ASV tās izpēte attālinājās no Dirkema klasiskās pieejas. Kā raksta Marko Orru, Eiropā sociālajās zinātnēs diskutē par sabiedrības mērķiem, bieži tos arī kritizējot, bet ASV analizē un kritizē līdzekḷus mērḳu sasniegšanai, pašus mērḳus uzskatot par sociālu faktu (Orrù, 1987, pp.118-120).

Mērtona izejas punkts bija novērojums, ka ASv sabiedrībā, īpaši vidusšķirā, augstu vērtē panākumus un sasniegumus un par skaidrāko sasniegumu pazīmi uzskata finansiālu veiksmi. «Tikt dzivē uz augšu» nozīmē kḷūt bagātam, turklāt iespējami ìsā laikā. Nekḷūt bagātam nozīmē, ka esi dzìvē «zaudētājs». Tā dēvētais «amerikāṇu sapnis» cildināja mērḳus, ko praksē tikai retos gadijjumos bija iespējams sasniegt ar likumīgiem lïdzekḷiem. Lìdzsvarotas (Mērtons lieto jēdzienu effective equilibrium) kultūras un sociālās struktūras attiecības būtu tādas, ka kultūra iezīmē sabiedrības mērḳus, uz kuriem tai būtu jāvirzās, savukārt sociālā sistēma nodrošina līdzekḷus šo mērku sasniegšanai. Savtīgi pašlabuma meklējumi kultūrai būtu jālīdzsvaro, uzsverot sabiedrības kopīgos ideālus un vērtības. Praksē dažkārt institucionalizētie mērḳi nav sasniedzami ar pieejamajiem līdzekḷiem, un tas arī rada deviantu uzvedību. Atškirībā no Dirkema skatijjuma, Mērtona teorijā cilvēka dabai ir maza nozime. Egoismam, alkatỉbai un tamlīdzīgām nelāgām rakstura iezīmēm ir sociāla izcelsme, turklāt tās ir situatīvas - atkarīgas no kultūras un sociālo institūciju attiecībām konkrētā sabiedrībā. Taču Dirkems un Mērtons ir vienisprātis, ka anomija liecina par normatīvā regulējuma vājumu.
Tomēr Dirkems vērtēja anomiju kā nepietiekama vai pārspīlēta regulējuma izraisitu patoloğisku stāvokli, taču Mērtonam anomija ir cilvēka reaktīva stratēóijia iepriekšminētajā mērḳu un to sasniegšanai pieejamo lỉdzekḷu lìdzsvara nobìdes situācijā. Cita atškirība atrodama Dirkema un Mērtona uzskatos par anomijas izplatỉbu dažādos sabiedrības segmentos. Dirkema secinājums bija - anomija var būt izteikta dažādos laika nogriežņos dažādā pakāpē (piemēram, križu laikos tā būs izteiktāka), taču, ja reiz tā iestājusies, tad skar visu sabiedrību kopumā. Savukārt Mērtons raksta, ka anomijas iespaids un tās radītās spriedzes līmeṇi var būt augstāki dažām sabiedrības grupām, piemēram, migrantiem vai sabiedrības zemākajām šḳirām. Atšḳirības cēloṇi meklējami vinu pozicionējumā sabiedrības struktūrā. Ja individam izglìtỉbas vai finanšu trūkuma, vai citu iemeslu dēl ir grūtāk isstenot «amerikāṇu sapni», viṇš asāk izjūt ārējo spiedienu to darìt (Merton, 1968). Kopējā sabiedrības anomie tad izpaužas kā individuāla, subjektīvi izjusta anomia (Merton, 1964, pp. 225-228). Anomijas un spriedzes pakāpi ietekmē arī indivìdu atškirīgie socializācijas līmeṇi (Merton, 1968, pp. 203-209).

Anomiska Mērtona teorijā ir jebkura situācija, kad sabiedrības mērḳi rada ārēju spiedienu un liek cilvēkam izmantot tehniski visreālākos lỉdzekḷus, kas nav institucionāli leğitimizēti. Anomiju rada kultūras spiediens būt veiksmiggam par katru cenu, nevis vienkārši kāda atsevišķa cilvēka vēlme tādam būt. Mērtons norāda, ka dažādi noziegumi un netikumi kḷūs aizvien izplatītāki un sociāli akceptējamāki, ja vien dzišanās pēc veiksmes un tās ārējām pazìmēm tiks nošķirta no piemērotiem likumigiem institucionāliem līdzekḷiem.

Mērtons kategorizē kopumā piecus mērķu un līdzekḷu attiecỉbu modeḷus un līdz ar to piecas iespējamās indivìda stratēǵijas konkrētos gadijumos, ko pazīstam kā viṇa spriedzes teoriju. Tie ir saskaņa (conformity) - ja kultūras definēto mērķu sasniegšanai pieejams pietiekams daudzums institucionalizēto lïdzeklu; inovācija (innovation) - ja individam ir pieṇemami mērḳi, taču pietiekamu līdzekḷu trūkst un nākas tos radìt; rituālisms (ritualism) - ja mērḳi ir zemi vai ierobežoti, bet to sasniegšanai leğitīmu iespēju pietiktu; atkāpšanās (retreatism) - ja indivīdam nav ne nozīmīgu mērḳu, ne līdzekḷu tādu sasniegšanai; sacelšanās (rebellion) - ja indivìds gan pārdefinē mērḳus, gan izvēlas jaunus līdzekḷus to sasniegšanai. Mērtons raksta, ka rituālisms ir stratēógija, ko biežāk izvēlas vidusškiras pārstāvji, bet inovācija - ko izvēlas zemākās škiras (Merton, 1968, pp. 203-209), arī atkāpšanās vairāk raksturīga zemākajām šḳirām (Merton, 1968, p. 242). Inovācija ir visdeviantākā stratēǵija, ar visaugstāko likuma pārkāpšanas iespēju, kamēr rituālisms ir "pārspilēta saskaṇa» (overconformity), vismazāk anomiskā stratēgijija (Merton, 1968, pp. 238-241). Vai par šo snaudošo harmoniju būtu jāpriecājas, tas ir cits jautājums.

M. Sīmans attīstijja Mērtona agrīnās idejas tālāk. Vina interpretācijā anomija bija identificējama ar «beznormību» (normlessness), kad sociāli 
nepieṇemama uzvedība ir vienīgais veids, kā sasniegt mērki, bet to pavada bezspēcība, bezjēdzība, sociālā izolācija, kultūras atsvešinātība un pašatsvešinātība (Seeman, 1959).

\section{Kvantitatīie}

anomijas pētijum

20. gadsimta 50. gadu otrajā pusē parādỉjās pirmie mēǵinājumi anomiju ne vien aprakstīt, bet arī mērìt, izmantojot kvantitatīvus rādītājus. Par nozīmīgāko méǵinājumu var uzskatìt Leo Sroles izstrādāto einomijas-anomijas mērijjumu skalu. Strole attīstija tālāk idejas, kas jau bija atrodamas Makaivera (MacIver, 1950) un Lasvela (Lasswell, 1952) publikācijās. Būtiskākais iespaids nāca no Makaivera atzinnas, ka kultūras sabrukuma cēlonis ir indivīdu vērtỉbu sistēmas distancēšanās no kopīgajām sabiedrības vērtībām, paḷāvības uz nākotni zudums un tam sekojošā orientācija uz dzīvi tagadnē. Anomiskais cilvēks tādējādi «ieklausās tikai sevī, bet neatskaitās nevienam» (MacIver, 1950, p. 84). To var arī uzskatīt par psiholoǵisku pašaizsardzības stratēǵiju strauju sociālu pārmaiṇu apstākḷos.

Arī Sroles uzmanības centrā bija anomija individuālā līmenī - tas ir, iespaids, kādu sabiedrības strukturāla anomie atstāj indivìda pasaules uztverē. Šo nošķīumu pārṇēma arī Mērtons savos vēlākajos anomijai veltitajos darbos. Srole piedāvāja nošḳirt anomie kā sabiedrības raksturlielumu un anomia kā individuālu stāvokli. Latviešu valodā, kur lietojam tikai vārdu «anomija», to ir neiespējami atspoguḷot. Anomie Strole raksturo kā normu trūkumu (normlessness) un norāda, ka to nav iespējams empīiski nomērìt. Anomia ir jēgas trūkums (meaninglesness) cilvēka pasaules uztverē un darbībā. Srole identificēja piecas anomia dimensijas, kas tika attiecīgi operacionalizētas piecos anketas jautājumos. Tie attiecās uz 1) individa subjektīvo sabiedrības attīstības novērtējumu; 2) individa subjektīvo vēlmi dzìvot tagadnei, nevis nākotnei; 3) cilvēka pạāvỉbas trūkumu attiecībā uz citiem cilvēkiem; 4) amatpersonu distancēšanos no cilvēka reālās dzīves problēmām; 5) pārliecības trūkumu, ka bērniem nākotnē būs labāka dzive nekā respondentam pašam. Anomijas pretstata raksturojumam Srole aktualizēja ideju vēsturē jau pazīstamo einomijas jēedzienu. Jau sengrieḳu politikisis Solons to bija lietojis sabiedriskās kārtības iemiesojuma raksturojumam (skat. Halberstadt, 1955). Šis mainigais, Srole rakstija, attiecas uz indivīda saistību ar citiem pārākajā pakāpē (self-to-others-belongingness) un atrodas skalas anomijai pretējā polā (Srole, 1956, p. 711).

Sroles ieskatā attiecibas starp amomie un anomia ir savstarpēji ietekmējošas. Individuālo anomia var skaidrot kā radušos sociālās anomie klātbūtnē un ietekmē, taču arī ievērojams individuāli anomisku personu skaits sabiedrībā paaugstina sabiedrïbas anomie lìmeni. Taču praksē ar Sroles piedāvātās skalas palīdzību var mērìt tikai individuālo anomiju un depresīvo, pesimistiski noskanoto, dzives jēgu un ticību nākotnei zaudējušo indivīdu skaitu konkrētā sabiedrībā. Tas parāda sabiedrības noskaņojumu, taču maz palïdz saprast anomijas cēloṇus. Anomia var raksturot minēto noskaṇojumu loti dažādos sociālos apstākḷ - piemēram, finanšu krīzēs, pēc darba zaudējuma vai nepietiekamas sociālās drošỉbas apstākḷos.

Sroles skala tikusi vairākkārt modificēta un uzlabota (Dean, 1965; Seeman, 1967; Teevan, 1973; Travis, 1993), savukārt pats individuālās anomijas jēdziens - pārinterpretēts. Tā, piemēram, H. Makkloskijs un J. Šārs izpētīja, ka individuālo anomiju ietekmē ne tikai sociāli faktori, bet arī personibas ippatnības, emocionalitāte un kognitivās spējas (McClosky \& Schaar, 1965).

Par anomijas kvantitatīvās izpētes intensīvāko periodu jāuzskata laika posms no 20. gadsimta 50. gadu beigām lìdz 70. gadu vidum. Anomia šķiet salīdzinoši labi pakḷaujamies kvantitatīvai socioloğiskai pētniecībai, taču anomie ir sabiedrības stāvoklis, ko būtu pārāk sekli interpretēt kā sabiedrības vīlušos locekḷu skaita rādītāju. Turklāt anomijas rādītāju aprēkins visai maz pasaka gan par anomijas cēloṇiem, gan sekām. Jaunāki empīriski pētijumi, par kuriem būs runa nodaḷas noslēguma dạ̦ā, tiecas piedāvāt kombinētu metožu izmantošanu.

\section{Pītera Bergera}

anomijas teorija

Paralēli kvantitatīvajiem pētījumiem anomijas tēma piedzìvoja arī teorētisku attīstìbu, kḷūstot par nozīmìgu elementu Pìtera Bergera reliǵijas teorijā (Berger, 1967). Bergeram «anomija» nozīmē nomos bojājumu. Savukārt nomos ir «jēgpilna kārtỉba» (meaningful order), ko veido sabiedrībā izplatītais pasaules uzskats jeb «uzticamības struktūra» (plausibility structure) visplašākajā nozīmē un tās ētoss - vērtības un dzivesveids, kas tiek objektivēts kā normativis.

Nomos izveidojas sociālās konstrukcijas ceḷā. «Sociāli konstruēts» ir plaši lietots, taču bieži pārprasts un primitivizēts jēdziens. Sociālā konstrukcionisma klasiki Pìters Bergers un Tomass Lukmans aprakstijja, kā realitātes konstruēšanas dialektiskie procesi noris trijos soḷos jeb posmos, un tieši tādā pašā perspektīiā Bergers apraksta nomos sociālo konstruēšanu. Šos soḷus vinin nosauca par eksternalizāciju, objektivāciju un internalizāciju (Berger \& Luckann, 1965). Tikai aptverot tos visus kopā, ir iespējams aptvert sociālās konstruēšanas procesu pilnībā. «Eksternalizācija» ietver cilvēka uz āru vērstās fiziskās un mentālās aktivitātes - tās «uzbūvē» cilvēka dzīvespasauli, kurā viṇš iemājo kā sociāla būtne, kas vēlas sasniegt drošìbu, ekonomisku labklājỉbu un emocionālu apmierinājumu visā savas dzives laikā. Tādā veidā cilvēki kopā veido sabiedrību. Tomēr jau kopš pirmajiem dzìves gadiem cilvēks tiek socializēts sabiedrībā, kura viṇu jau sagaida kā citu cilvēku kopīgas darbỉbas produktu. Sociālās institūcijas - kā valsts, ğimene, 
valoda un kultūra -ir reālas, objektīvas parādības, vienlaikus būdamas cilvēku darbības rezultāts. Tās ir objektivētas, jo pastāv neatkarīgi no cilvēka gribas. Nomos ir šāda-objektivēta realitāte.

Taču cilvēks piedzimst sociālā pasaulē, bet bez sociālām zināšanām. Viṇam nākas piemērot savu subjektivās pieredzes pasauli objektivajai realitātei, tostarp sociāli pieṇemamai uzvedībai, sociālajām vērtībām un normām. Šo procesu Bergers un Lukmans sauc par «internalizāciju». Bergers to apkopo šādā formulā: «Eksternalizācijas celā sabiedrība ir cilvēka darbības produkts. Objektivācijas ceḷā sabiedrība kḷūs par realitāti sui generis. Internalizācijas ceḷā cilvēks ir sabiedrības produkts.» (Berger, 1967, p.4)

Sabiedrība sociālā konstrukcionisma izpratnē ir kultūras produkts, kas rodas eksternalizējošas aktivitātes rezultātā. Veidojot attiecības ar sabiedrību, cilvēks vienlaikus konstruē arī savu identitāti. «Realitātes sociālajā konstruēšanā» Lukmans un Bergers apraksta sabiedrību kā vienlaikus objektīvu un subjektīvu realitāti, tā pastāv neatkarīgi no katra atseviška indivìda vēlmēm un sajūtām, tomēr ir atkarịga no tās locekḷu aktivitātēm un sociālajām interakcijām kopumā. Sabiedrības objektīvo raksturu veido vairāki procesi. Autori daudz uzmanības velta institucionalizācijai kā vienam no tiem. Institucionalizācijas loma ir vislabāk saskatāma gadijjumos, kad eksternalizācijas ceḷā radītas sociālās institūcijas tiek nodotas tālāk citai paaudzei. Institūcijas raksturo vēsturiskums un kontroles mehānismi. Būtisks institucionalizācijas procesa rezultāts ir tas, ka institucionalizācija lauj katram sabiedrības loceklim paredzēt citu sabiedrỉbas locekḷu uzvedỉbu, jo viṇi rēḳinās, ka vairums respektēs sociālās normas.

Savukārt darba dališana Bergeram un Lukmanam ir institucionalizācijas rezultāts. Konkrētas zināšanu izplatības funkcijas tiek asociētas ar konkrētiem institūtiem jeb eksternalizācijas ağentiem, ne ar plašākām sabiedrỉbas masām. Vini raksta:

Institucionālā pasaule tad tiek pieredzēta kā objektiva realitāte. Tai ir vēsture, kas aizsākusies pirms individa dzimšanas un ko neaptver vina biogrāfiskā atmiṇa. Tā bija tur pirms viṇa dzimšanas un paliks tur pēc vina nāves. Šai vēsturei pašai par sevi, kā pastāvošo institūciju tradicijai, piemìt objektīvs raksturs. Individuālā biogrāfija tiek novērtēta kā viena no epizodēm sabiedrỉbas objektîvajā vēsturē. Institūcijas kā vēsturiskas objektīvas fakticitātes uzrunā individu kā nenoliedzami fakti. [..] Tās pretojas viṇa mēǵinājumiem tās mainìt vai pārṇemt. Tām piemìt draudīga vara gan pašām par sevi, pateicoties to fakticitātei, gan caur svarigāāo institūciju rīcībā esošajiem kontroles mehānismiem. Institūciju sociālā realitāte nemazinās no tā, ka indivìds nesaprot to darbības nolūkus vai darbïbas principus. (Berger \& Luckmann, 1965, pp. 77-78)
Bergers un Lukmans norāda, ka objektivitātei, kas raksturo realitāti cilvēka pieredzē, nav ontoloğiska statusa, kas būtu neatkarīgs no cilvēciskās aktivitātes, kura to ir radījusi,-_sabiedrība un tās institūcijas nepastāv ārpus un pirms pieredzes.

Vienlaikus sabiedrība ir arī subjektīva, internalizēta realitāte. Indivìds kḷūst par sabiedrības locekli, piešķirot objektivajai realitātei personīgu, individuāli nozimīgu jēgu.

Nomos ir sabiedrības izvēle. Katrā reizē sabiedrība un tās institūcijas būtu varējušas izvēlēties arī citādi (piemēram, pieṇemt citādu likumu, pielūgt citu dievību, sekot citiem līderiem u. tml.), tomēr, ja izvēle ir notikusi, sabiedrỉba uzskata to par pašsaprotamu, un socializācijas ceḷa šis objektivizētais priekšstats arī tiek uzturēts turpmāk. Sabiedrība sargā savu kārtību ne vien objektīivi-ar savu sociālo institūciju palīdzību, bet arī subjektīvi, strukturējot individuāāās sabiedrības locekḷu apziṇas, uzsver Bergers (Berger, 1967, p. 21).

Nomos, raksta Bergers, atkal un atkal jābūvē iepriekš aprakstîtajā trīsdaḷigâas sociālās dialektikas procesā, bet, reiz uzbūvēts, tas darbojas kā vairogs pret anomizācijas draudiem. Dzìvespasaules sociālā konstruēšana savā būtībā ir nomizējoša jeb kārtojoša aktivitāte, vairogs pret eksistenciālajām bailēm, ko indivīdam rada atsvešinātība no sociālās pasaules. Tieši nomizāciju Bergers uzskatijja par sabiedrības vissvarīgāko funkciju (Berger, 1967, p. 22). Taču ne vienmēr tā darbojas vienlīdz veiksmīgi. Nevainojams nomos ir iespējams tikai teorētiski - tad, ja eksternalizācijas un internalizācijas procesi būtu simetriski. Praktiski tā tomēr nenotiek, tāpēc nevienu nomos nevar uzskatīt par pilnībā drošu un neievainojamu. Anomizācijas draudi var ìstenoties praksē, tāpēc «sakrālajā pārklājā» rodas plaisas un tas var tikt arī pilnībā saplosìts - gan iekšēju procesu, gan ārēju spēku darbỉbas rezultātā. Tie var likt apšaubìt paša nomos pastāvēšanu. Nomos eksistence visvairāk tiek apšaubìta križu laikā. Privātas krīzes nākas piedzìvot katram savu pieredzi pārdomājošam cilvēkam, piemēram, apzinoties savu mirstīgumu vai pieredzot tuvu cilvēku nāvi, ko viṇam ir grūti pieṇemt (internalizēt) kā normālas lietu kārtības sastāvdaḷu. Tāpat eksistenciālas šausmas var pārṇemt cilvēku sociālu un ekonomisku krī̌u laikā, kad šḳiet, ka nedarbojas pierastie likumi un pārṇem notiekošā bezjēdzības, neprāta, ačgārnības un bezspēcības sajūta.

Protams, sabiedrības tiecas savu nomos nosargāt un nostiprināt, jo alternatīva (anomija) ir biedējoša. Katra sabiedrība, raksta Bergers, būvē cilvēciski jēgpilnu dzìvespasauli. Cilvēkam jāspēj saistīt sava privāti nozīmīgā pasaule ar pasauli kosmiskā nozìmē, pirmo balstot otrajā, kam cilvēks ir gatavs pakḷauties un atsaukties. Bergers to sauc par «kosmizēšanu» (cosmization). Bergera darbos lietots viens apzimējums - anomy, tā radot iespaidu, ka viṇš nenošḳir kolektīvo sociālo un individuālo anomiju. Bergers norāda, 
ka anomy nav nekas cits kā Dirkema anomie angliskojums (Berger, 1967, p.190), tā vienmēr ir sociāla un raksturo disharmoniskas indivīda un plašăkas sabiedrības attiecības, savstarpēju neuzticēšanos, nespēju vienoties par kopīgām vērtībām, sociālo normu un sociālo institūciju vājumu.

Teorijas un empīiskās analīzes sintēze anomijas pētījumos 20. gadsimta nogalē un 21. gadsimta sākumā

mijas definiciju. Arī hipotēžu par to, kas tieši rada anomiju, kḷūst aizvien vairāk (Passas, 1995, pp.106-107). Tas iezīmē aizvien plašāku, bet arī fragmentētāku pētījumu lauku. Tomēr šķiet, ka iespējams saskatìt trīs nozīmīgākās tendences. Pirmkārt, ir radies lielāks skaits pētijumu par anomiju teritoriāli, konkrētās sabiedrībās (piemēram, skat. pētỉjumus par dažādām valstīm - Atteslander et al., 1999). Otrkārt, intensìvi tiek pētîta anomija konkrētu organizāciju vai sociālo grupu kontekstos, mazāk vispārinot šo jēdzienu uz plašāku sabiedrību, turklāt biežāk norādot uz «anomizācijas tendencēm», nevis aprakstot to kā stabilu stāvokli konkrētā laika nogrieznī (Passas, 1999, p. 102). Trešo virzienu raksturo mēǵinājumi sintezēt iepriekšminētos specifiskos pētijumus ar jaunu teorētisku piedāvājumu, kas meklē anomijas indikatorus ārpus individuālās anomijas pazimēēm. Piemēram, Johans Galtungs aicināja anomijas analīzē ietvert trīs lìmeṇusindividuālo, sociālās un/vai pasaules sistēmas līmeni. Individuālā gadỉjumā personai trūkst vērtỉbu vadỉbas un normas nav visaptverošas, internalizētas. Nākamajā līmenī tā ir sabiedrība, ko nevada kopigas, lìdzdalìtas vērtības un vērtïbas un normas nav institucionalizētas. Visbeidzot, pasaule var būt līdzịgā stāvoklī, ja lielāks skaits sabiedrību piedzivo iepriekš minētās anomālijas (Galtung, 1999, pp.197-199). Tālāk Galtungs izšķir dažāda mēroga anomijas - trīs «lielo pārmainuu» anomijas un virkne mazāku. Trīs lielās pārmaiṇas bija pāreja no primitīvās uz tradicionālu sabiedrību (t.i.,, lauksaimniecības un vietsēdības rašanās), pāreja no tradicionālās uz moderno sabiedrību, ko aprakstija Dirkems, un no modernās uz postmoderno sabiedrību (Galtung, 1999, p. 200). Mazāka mēroga anomijas sastopamas modernās sabiedrībās un parasti izpaužas vai nu kā vienas personas darbošanās divās pretrunīgās lomās (Galtunga minētais piemērs - tradicionālas ǵimenes galva ir strādnieks modernā rūpnīcā) vai politisku svārstību laikos, piemēram, no diktatūras uz demokrātiju un tad atpakal uz diktatūru. Būtiska problēma kvantitativajā anomijas pētniecībā, uz ko norāda Galtungs, ir tā, ka anomija ir būtībā negatīvs stāvoklis, kaut kā trūkums, «ne-attieksme» (non-attitude) (Galtung, 1999, p. 201), tādēl to grūti operacionalizèt. Citi autori aicina izvēlēties tādus anomijas indikatorus, kas būtu mērāmi, t.i., kvantificējami, plaši pieṇemti, līdzsvaroti (t.i.,, politiski neitrāli un lautu mērìt gan pozitīvās, gan negatīīās ietekmes), lautu fiksēt to izmainas dažādos apstāklos un laika gaitā (Atteslander et al., 1999, pp. 217-218). Tādi būtu ne tikai aptaujas ceḷā iegūti dati par individuālo anomiju līmeni, bet arī ekonomiski indikatori (vidējie ienākumi valstī, inflācija, parādu līmenis, bankrotu skaits, nabadzības un noziedzības statistika, ienākumu nevienlīdzība u. tml.), demogrāfiskie rādītāji, iedzìvotāju blīvums, izglìtỉbas līmenis, kā arī sociāli rādītāji, kā iekšējās un ārējās migrācijas statistika, etnisko konfliktu biežums, bezpajumtnieku skaits, laulības šḳiršanas statistika u.c. Tas ḷautu izveidot kompozìtu anomijas indikatoru. Kopumā jāsecina, ka vērojama tendence anomijas pētniecībā atgriezties pie makrolīmena analīzes, līdzịgi, kāda tā bija laikā, kad anomijas tēma ienāca sociālo zinātnu apritē. 


\section{Globālo vērtību orientācija Latvijas iedzīvotāju vidū}

Mūsdienās par vairāku globālu un nacionālu politiku prioritāti tiek izvirzìta ilgtspējiga attīstiba. Apmierināt nepārtraukti pieaugošā iedzivotāju skaita vajadzibas, vienlaikus nodrošinot nepieciešamo atbalsta sistēmu visas planētas kopịgajai ekosistēmai, ir viens no galvenajiem un reizē grūtākajiem cilvēces uzdevumiem. Ekonomiskā un tehnoloğiskā attīstība ir ievērojami uzlabojusi cilvēces stāvokli. Pieaugusi vispārējā cilvēku ekonomiskā labklājība, samazinājusies mirstība, uzlabojusies lasītprasme, rakstîtprasme un komunikāciju tehnolog̣iju izmantošana. Tomēr citu attīstības mērḳu sasniegšanā, piemēram, ienākumu un sociālās nevienlīdzības mazināšanā, klimata pārmaiņu jomā, vērojami ne tik daudzsološi panākumi. Globālās attīstības nevienmērīgajam sniegumam ir daudz iemeslu, tomēr nav iespējams ignorēt attīstības sociālo un psiholoğisko dimensiju, kas centrā izvirza arì iedzīvotāju attieksmi un uzvedību. No pirmā acu uzmetiena globālo aptauju rezultāti par iedzivotāju attieksmi pret jautājumiem, kas saistīt ar globālo ilgtspēju, škiet iedrošinoši. Pieaug iedzivotāju izpratne par nepieciešamību orientēt valsts politiku uz ilgtspējiggas attīstības mērḳiem, t. sk arì ieviest aktîvus pasākumus klimata izmainu mazināšanai. Tomēr daudzo jautājumos atklājas arì ievērojamas atškirības starp cilvēku attieksmi un uzvedību. Iedzīvotāji ne vienmēr praktiski iesaistās darbībās, kas tendētas uz ilgtspējīgu dzives veidu. Plaisas, kas radušās starp attieksmēm un uzvedību, ir ğan pētnieciskās kopienas, ğan politikas veidotāju uzmanības vērtas, jo parāda, ka attīistības risinājumi prasa ne tikai vairāk līdzeklu un tehnoloğisko progresu, bet arī pārmainas cilvēku prātos un sirdīs.

Ilgtspējības sociālā un psiholoǵ̛iskā dimensija kḷust īpaši aktuāla arī politiskās elites retorikas kontekstā. Vairāki ietekmīgi pasaules politiki ir izmantojuši populistiskus un nacionālistiskus saukḷus, aicinot savas valsts intereses izvirzit pirmajā vietā un atjaunot sienas un žogus uz valsts robežām. Nesenie populistu politiku panākumi vairākās Eiropas valstìs un Amerikas Savienotajās Valstīs liecina, ka brīvas un atvērtas sabiedrības idejas, kas reiz drupināja Berlīnes mūri, ir pabālējušas. Lai novērstu sabiedrības uzmanību no visaptverošu problēmu risināšanas, politiskie spēki distancējas no universālo vērtību aizsardzības un keras pie daudz izdevigākas «vainīgo meklēšanas» caur protekcionisma un populisma retoriku, kas iekḷauj emocionāli piesātinātu aicinājumus pretnostatìt «tautu» un «eliti», «vietējos» un «svešos». Nav grūti iedomāties, ka šāda retorika varētu ietekmēt arī kolektīvo attieksmju un vērtỉbu fonu, veicinot uz sevi, savu grupu vērstu, noslēdzošāku attieksmju veidošanos. Tas ievērojami apgrūtinātu risinājumus problēmām, kurām šobrī ir izteikti pārnacionāls raksturs un kuru risinājums ir lielā mērā atkarīgs no nacionālā un globālā mēroga elites apzinas un izpratnes.

Sabiedrības dominējošās vērtību orientācijas ḷauj izprast to, kā noteiktas vērtības ietekmē cilvēku interesi par notikumiem konkrētās pasaules dalās vai kāpēc atseviškas vērtỉbas veicina stiprāku saikni ar vietējo, 
reg̣iionālo, nacionālo un/vai globālo līmeni. Tas ir tāpēc, ka globalizācija ir daudzšķautṇains process, kam joprojām ir neskaidra vietējo un globālo saistību sajūtu mijiedarbība.

Nemot vērā globalizācijas procesu sarežg̀itību, globalizācijas ietekmi uz iedzivotāju attieksmēm ir visai sarežğîti noteikt. Arī socioloğisko pētijumu rezultāti par globalizācijas ietekmes vērtējumu nesniedz viennozimīgas atbildes. Daži pētnieki apgalvo, ka globalizācija pavājina nacionālo identitāti un pastiprina globālo identitāti (Antonsich, 2009; Beck, 2006; Norris \& Inglehart, 2009). Tā, piemēram, Gela Arjeli (Gal Ariely) 89 valstu pasaules vērtību pētijumā konstatē, ka valstīs ar straujākiem globalizācijas tempiem iedzìvotāji ir nelabvēlīgāk noskanoti pret globalizāciju (Ariely, 2016). Savukārt citi pētnieki uzskata, ka globalizācijas ietekme uz iedzivotāju attieksmēm ir pārvērtēta un iedzīvotāju attieksme un vērtējumi ne vienmēr ir saistīti ar pašas globalizācijas vērtējumu (Calhoun, 2007; Jung, 2008). Pētijjumi par cilvēka vērtībām, attieksmēm un uzvedību saistỉbā ar ilgtspējiggas attīstỉbas dimensijām guvuši spēcīgu impulsu visā pasaulē (ASv Valsts pētniecības padome, 2002; Raskin et al., 2002). Kopumā tie liecina par iedzīvotāju attieksmju un vērtību transformāciju kompleksitāti un aicina sistemātiskāk un visaptverošāk izmantot daudzveidīgu empīisko datu klāstu (Antonsich, 2009). Latvijas sabiedrības vērtīborientācijas pētijumi SUSTINNo projekta ietvaros uzskatāmi par vienu no mēǵinājumiem šajā virzienā. Šì nodaḷa sniedz ieskatu Latvijas sabiedrības attieksmēs saistībā ar dažādiem globālās attīstības aspektiem, piemēram, attīstības palīdzību, vidi, pārticību, nabadzību un patēriņu, zinātni un tehnoloğijām, ienākumu taisnīgumu un cilvēktiesībām. Izmantojot pieejamos datus par iedzīvotāju attieksmi un vērtību orientāciju attiecībā uz globālo attīstību, raksts pievēršas saiknei starp cilvēku personiskajām vērtì̄ām un globālo identitāti. Balstoties uz Šaloma Švarca (Salome Schwartz) vērtību teoriju, îpaša uzmanỉba tiek pievērsta transcendences vērtïbu nozīmei globālās vērtību orientācijas stiprināšanā (Schwartz, 2012). Saskaṇā ar Švarca piedāvāto vērtību modeli transcendences vērtības ir saistītas ar universālisma un labvēlības kvalitātēm. Tādēl varētu pienemt, ka indivìdiem ar izteiktākām transcendences vērtībām varētu piemist arī tolerances un atvērtības kvalitātes, kas savukārt sekmētu viṇu atbalstu noteiktiem pārnacionālā lïmeņa kolektīvajiem labumiem, piemēram, vides aizsardzībai, sociālajam taisnīgumam, vienlīdzībai, mieram un skaistumam pasaulē. Transcendences vērtību esamība sabiedrībā savukārt varētu sekmēt iedzivotāju kosmopolītiskas un globālas vērtību orientācijas.

Globalizācija un sociālā identitāte
Globalizācija ir viena no visvairāk apspriestajām tēmām sociālajās zinātnēs. To vispārīgi varētu raksturot kā procesu, kas saistìts ar «preču, pakalpojumu, naudas, cilvēku, informācijas un kultūras pārrobežu plūsmu palielināšanos» (Held et al., 1999, p.16). Kaut gan globalizācija ir ārkārtīgi sarežğìita parādība, kas ietver ekonomiskus, politiskus un kultūras aspektus, nevar ignorēt to, ka tā var atstāt arī noteiktas sociāli psiholog̣iskas sekas uz iedzīvotājiem. Globalizācijas procesi nosaka kontekstu tam, kādā veidā «cilvēki domā par sevi saistībā ar sociālo vidi» globalizācijas apstākḷıs (Arnett, 2002, p. 777).

Teorētiskā līmenī globalizācijas sekas bieži vien tiek interpretētas no divām normatīvām perspektīvām. Kosmopolītiskajā perspektīvā globalizācija tiek aplūkota kā spēks, kas veido globālus preču un informācijas patērētājus. Valstu nacionāāās pārvaldes mehānismi (valdības, parlamenti) vairs nepiedāvā ekskluzivvu kultūras kontroli pār saviem pilsoniem un teritoriju (Barber, 1996; Guibernau, 2001). Saskaņā ar šo perspektîvu globalizācija rada arī jaunas identitātes, kas izškīdina nacionālā un lokālā līmena identitāšu formas (sk., piemēram, Hobsbawm, 1992). Rodas jaunas identitātes un to izpausmes, kas vairāk atbilst kosmopolītiskiem pasaules uzskatiem, un tās nav balstītas uz valstu nacionālajiem un vietējā līmeṇa naratīviem (Beck, 2006). Kosmopolītisms šajā kontekstā simbolizē cilvēka vai kopienas eksistenci pasaulē, kura atrodas nepārtrauktā pārveidošanās procesā (Hansen et al., 2009, p. 587). Šo jēdzienu sākotnēji radīja kiniḳis filozofs Diogens (4. gadsimts p.m.ē.), kurš raksturoja sevi kā kosmopolītu - kosmosa, nevis noteiktas pilsētvalsts pilsoni (Hansen et al., 2009). Mūsdienu literatūra nošḳir politisko kosmopolītismu, kas vairāk vērsts uz institūcijām, politikām, likumiem un darijumu procesu un kura mērkis ir aizsargāt cilvēktiesības un dzīvesveidu, rosino tādu politisko dienaskārtību, kas nebūtu balstīta uz nacionālismu. Pastāv ar morāls kosmopolīisms, kas pievēršas altruisma jautājumam, aicinot paplašināt pienākumu apjomu ārpus katra cilvēka tiešā sociālā loka. Kvame Entonijs Apija (2006) (Kvame Anthony Appiah) izmantojis terminu «iesaknotais kosmopolītisms» (rooted cosmpolitanism), ar to domājot pilsoni, kurš ievēro vispārējās tiesības, bet tajā pašā laikā augstu vērtē arī viṇa/viṇas morālās saistības pret vietējo kopienu (Appia, 2006). Kultūras kosmopolītisms izcel cilvēku, tradīciju un dažādu prakšu sajaukšanos, vienlaikus uzsverot, ka cilvēki var sakṇoties vairāk nekā vienā kultūrā vai kopienā (Hansen et al., 2009, p. 589). Visbeidzot, ekonomiskais kosmopolītisms koncentrējas uz globāliem ekonomiskiem pasākumiem, ko iespējams panākt ar tehnolog̣ijām un atvērtiem ekonomikas režìmiem. Atkarībā no normatīvās pozìcijas ekonomiskais kosmopolītisms cildina vai kritizē kapitālismu un tā kārtību.

Otras tā dēvētās kosmopolītisma reakcionārās perspektīvas (backlash perspective) atbalstītāji globalizāciju ataino kā potenciāli destabilizējošu spēku, kas grauj tautu drošības un stabilitātes izjūtu. Nepieredzētā cilvēku mobilitāte un informācijas apmaiṇa pāri robežām tiek saistìta ar iedzīvotājus potenciāli apdraudošu imigrāciju, nestabilu darba attiecību un 
neprognozējamu finanšu tirgu ietekmi. Lai atgūtu kontroli pār savu dzīvi, cilvēkiem saistošas liekas nacionālisma un religíijas formas, kas viṇiem nodrošina «piederības sajūtu» un sniedz drošības un stabilitātes izjūtu (Guibernau, 2001). Tādā veidā globalizācija faktiski tikai veicina nacionālisma, lokalizācijas vai parohiālisma attieksmju nostiprināšanos sabiedrībā (Kinnvall, 2004; Hermans \& Dimaggio, 2007).

Tikai nedaudzos nacionāla un starptautiska līmeṇa pētījumos ir pārbaudìtas abu globalizācijas perspektīvu izpausmes sabiedrībā. Pētijums Vācijā parādīja, ka iedzīvotāji, kas pakḷauti lielākai globalizācijas ietekmei nekā pārrobežu un transnacionālie ceḷotāji, visticamāk, pieṇems kosmopolìtisku attieksmi (Mau, Mewes, \& Zimmermann, 2008). Starpvalstu pētijumā, kura pamatā ir Pasaules vērtību apsekojumu (World Value Survey -WVS) dati, Pipa Norisa (Pippa Norris) un Ronalds Inglhārts (Ronald Inglehart) arī norāda, ka atbalsts kosmopolïtiskas pilsonības vērtībām liecina-dzive kosmopolītiskākā sabiedrībā vājina nacionālistiskas attieksmes (Norris \& Inglehart, 2009). Šo atziņu kritizē Džejs Kvans Jangs (Jai Kwan Jung), kurš izmanto līdzịgus datus, taču nerod atbalstu šādai tēzei (Jung, 2008). Judìte Breta (Judith Brett) un Entonijs Morans (Anthony Moran) (2011) konstatē, ka Austrālijas respondentu kosmopolīisma attieksmes ir vājākas tajās grupās, kuras pašas vairāk pakḷautas globalizācijas procesiem (Brett \& Moran, 2010). Autori atzīst, ka, visticamāk, globalizācijas psihosociālās sekas ir saistītas ar citiem faktoriem, piemēram, dažādu problēmu atspogulošanu informatīvajā telpā, kā arī ekonomisko un politisko situāciju valstī. Piemēram, teroristu uzbrukumi, kas saistīti ar aizdomās turamo imigrantu, potenciāli var izraisìt pret migrāciju vērstu retoriku, kas, savukārt, liek negatīvi raudzīties uz globalizāciju. Neviennozīmīgi secinājumi par iedzīvotāju attieksmi pret globalizāciju var rasties arī no dažādām globalizācijas interpretācijām un tās izpausmēm cilvēku dzīvē. Vairāki autori pētijjuši iedzìvotāju attieksmi arī pret specifiskiem globalizētas pasaules aspektiem (piemēram, vides aizsardzību, migrāciju), citi savos pētijumos izmantojuši kompleksus jēdzienus, piemēram, globālo pilsonỉbu, tajā ietverot vairākas attieksmes un uzvedības, kas kaut kādā mērā liecinātu par globālu orientāciju. Globālā pilsonība (vispasaules pilsonība) ietver pasaules izpratni, rūpes, kultūras daudzveidības uztveršanu, sociālā taisnīguma veicināšanu, ilgtspējibu un atbildības sajūtu (Katzarska-Miller, 2012). Pētnieki ir atklājuši, ka augstākā globālās pilsonības identifikācija ir saistìta ar sociālo taisnīgumu un respektu pret vides saglabāšanu (Katzarska-Miller, 2012). Vēlākā pētijumā tiek secināts, ka negatīvs globalizācijas attēlojums mazina globāāas pilsonības identifikāciju iedzivotāju vidū. Savukārt globalizācijas pozitivam atainojumam nav ipašas nozīmes iedzīvotāju globālajā identifikācijā (Snider et al., 2013).

Šajā pētijumā izmantotais vērtības modelis ir balstīts uz Šaloma Švarca vērtības teorijas modeliem (Schwartz, 2012) un R. Inglhārta materiālo/ postmateriālo vērtību modeli (Inglehart, 2008). Š. Švarca modelis sastāv no

57 vērtībām, kas sakārtotas desmit grupās: universālisms, labvēlība, tradīcija, konformisms, drošība, vara, panākumi, hēdonisms, stimulēšana, pašnoteikšanās. Tā kā vērtības šajās grupās ir savstarpēji konfliktējošas, Švarcs tās organizē aplveida struktūrā divu bipolāru dimensiju ietvaros. Pirmo dimensiju viņš dēvē par atvērtību pārmaiṇām (openness to change), kas kontrastē ar pašreizējā stāvokḷa saglabāšanas pozīciju (conservation). Otrā dimensija ietver uz sevi vērstas pašuzlabošanas stratēgiijas (self-enhancement), kas, savukārt, kontrastē ar t. s. paštranscendenci/transcendenci jeb sevis pārvarēšanu (self-transcendence). Iedzivotāju globalizācijas subjektīvā vērtējuma kontekstā varētu izvirzìt pieṇēmumu, ka paštranscendences vērtības vairāk uzsver tieši tās îpašỉbas, kas būtu nozimmīgas dzivei globalizētajā pasaulē. Saskanāa ar Š. Švarcu transcendences vērtības ietver universālismu (universalism) (izpratni, atzinību, toleranci, atvērtību visu iedzīvotāju labklājībai, vides aizsardzỉbu, viedumu, sociālo taisnīgumu, vienlīdzību, mieru un skaistumu pasaulē, vienotību ar dabu, vides aizsardzìbu), kā arī labvēlību (benevolence), ko, savukārt, veido tādas kvalitātes kā orientācija uz cilvēku labklājïbas uzlabošanu, noderīgumu, godīgumu, piedošanu, lojalitāti un atbildību.

Jāuzsver, ka minētās kvalitātes, lietojot globālās pilsonības (globa citizenship) jēdzienu un izmantojot izglìtības sistēmu, cenšas iedzīvināt arī ANO Izglitīibas, zinātnes un kultūras organizācija-UNESCO. Organizācija piedāvā visaptverošu pasaules mēroga pieeju attīstỉbas jautājumu risināšanai caur izglïtỉbas sistēmām, uzsverot iedzivotāju kompetenču palielināšanu par globāliem jautājumiem un vispārējām vērtībām, piemēram, taisnìgumu, vienlīdzību, cienu, daudzlīmenu identitātēm, kas pārsniedz atseviškas kultūras, reliğiskās, etniskās vai citas atškirības, piemēram, tāda ir piederības sajūta kopējai cilvēcei un cieṇa pret daudzveidību, spēja domāt kritiski, radoši un sistemātiski, pieṇemot dažādas perspektīvas. Izglītības saturs attīsta arī bērnu sociālās prasmes, piemēram, empātiju, spēju atrisināt konfliktus, komunikācijas prasmes, spēju tỉkloties un sadarboties ar dažādu izcelsmju un kultūru cilvēkiem, lai spētu kopīgi rīkoties un rast risinājumus globāla mēroga problēmām (UNESCO, 2014).

\section{ledzīvotāju attieksmes un uzvedība ilgtspējīgas} attīstības kontekstā
Lai gan daudzos pètījumos ir analizèta sabiedrības uztvere par globalizāciju kopumā, daži pētījumi ir pievērsušies sabiedribas attieksmei un uzvedibai ilgtspējiơas attīstības jomā. Tā, piemēram, Entonijs Leizerovics (Anthony Leiserowitz) un līdzautori ir snieguši visaptverošu pārskatu par dažādiem avotiem, kuru pamatā ir atkārtoti ievākti dati, piemēram, Pasaules apsekojums GlobeScan, Starptautiskais vides monitoringss, Ekonomiskās sadarbïbas un attīstỉbas organizācijas (OECD) apsekojumi, kā arī vienreiz veiktas aptaujas 
par specifiskiem globalizācijas aspektiem, piemēram, Pew Global Attitudes Project, Starptautisko sociālo zinātṇu programma (ISSP), Planet Health Check un Eirobarometra aptaujas (Leiserowitz, 2004). Šajos pētijumos aplūkoti tādi globalizācijas aspekti kā labklājība, attīstības palīdzība, ar vides saudzēšanu saistītā uzvedība, nabadzỉba, patēriņšs, zinātne un tehnoloǵija, ienākumu līmenis un ilgtspējigs dzìvesveids. Tālak minēti daži no galvenajiem starptautisko pētijumu secinājumiem, kas veido fonu tālākai izpētei.

LAB KLĀ̄ĪBA $\quad$ Kopš Otrā pasaules kara laikiem cilvēces attīstībā ievērojami uzlabojumi ir sasniegti bērnu izdzīvošanas rādītāju uzlabošanā, pieaugušo dzives ilguma un izglìtỉbas iespēju paplašināšanā. Taču situācija tādās jomās kā labklājība, labi atalgotu darbvietu pieejamība, darba apstākḷi, slimību izplatības apkarošana un veselības aprūpes pieejamība, kā arī vecu cilvēku spēja parūpēties par sevi vecumdienās nav būtiski uzlabojusies, gluži otrādi, ir pat pasliktinājusies (Pew Research Center for the People \& Press, 2004). Tātad tikai ekonomiskā attīstība pati par sevi vēl nespēj pilnvērtīgi apmierināt visu cilvēku prasības pēc labākas dzīves.

Attieksme pret ekonomisko attīstību un labklājỉbu ir plaši aplūkota Pasaules vērtību aptaujās (World Value Survey), kas norit kopš 1982. gada. Aptauju rezultāti kopumā apstiprina, ka pastāv sakarība starp ekonomisko un politisko situāciju valstī. Amerikānu sociologs Ronalds Inglhārts un vina pētnieku komanda apstiprina, ka starp iedzìvotājiem, kas dzīvo ekonomiski mazāk attīstìtās valstīs (tai skaitā arī bijušā padomju bloka valstīs), ir lielāks īpatsvars tādu, kam raksturīga materiālistiska vērtību orientācija, savukārt turīgākās valstīs ir vairāk iedzīvotāju ar postmateriālu vērtību orientāciju. Aptaujas liecina, ka pie noteikta ekonomikas attīstỉbas līmeņa, kurā iekšzemes kopprodukts sasniedz orientējoši 14000 ASV dolāru uz vienu iedzīvotāju, vispārējā ekonomikas attīstība ir saistìta ar iedzivotāju laimes vērtējumu (Inglehart, 1999). Pārsniedzot šo slieksni, apmierinātību ar dzīvi sāk noteikt nemateriālie faktori, piemēram, emocionālā labsajūta, nepieciešamība pēc pašizpausmes u.c. Inglhārts un vina kolēǵi norāda uz diviem galvenajiem attīstības vektoriem - tradicionālo/sekulāri racionālo, kā arī izdzīvošanas/ pašizpausmes vektoru. Tradicionālais/sekulāri racionālais vektors iezīmē atšķiiības starp tām sabiedrībām, kas reliǵiju uztver kā ḷti svarīgu savā dzīvē, un tām sabiedrībām, kurās relióijai cilvēka dzīvē netiek piedēvēta būtiska nozīme (Gaskova, 2014). Pāreja no izdzìvošanas uz pašizpausmes vērtībām kopumā ir saistìta ar modernizācijas procesu, kuru raksturo pieaugoša sabiedrības ekonomiskā labklājība. Pret R. Inglhārta interpretāciju vērstā kritika norāda, ka individuālās vērtību orientācijas nevar piedēvēt visai sabiedrībai. Vienas valsts ietvaros var pastāvēt daudz lielākas vērtību atšḳirības dažādu sociālo grupu starpā nekā dažādu valstu starpā. Kritika saistās arī ar Inglhārta materiālistisko deterministisko vērtỉbu interpretāciju.
Tiek norādīts, ka sociālie un ekonomiskie faktori var arī būtiski neietekmēt noteiktu iedzīvotāju grupu, piemēram, reliǵiozu cilvēku un garīgo praktizētāju, vērtību orientācijas (Gaskova, 2014, p. 101).

ATtīstīBas PALīDzīia Atbalstoša attieksme attiecībā uz attīstības palīdzību var sniegt valdībām un organizācijām lielāku stimulu novirzìt lỉdzekḷus attīstības projektu finansēšanai un vēl vairāk palielināt sabiedrības informētîbu par attīstības jautājumiem. 197o. gadā Apvienoto Nāciju Organizācijas (ANO) G̣enerālā asambleja nolēma, ka ekonomiski attīstītās valstīs o,7\% no nacionālā kopprodukta vajadzētu veltīt oficiālajai attīstỉbas palīizìbai (OAP). Patiesībā attīstības palīdzības finansējumam ir zema prioritāte. 200o. gadā tikai dažas valstis bija sasniegušas šo mērḳi (Dānija, Norvēóija, Nīderlande, Luksemburga, Zviedrija) un vairākas valstis tuvojās šì mērḳa sasniegšanai (Portugāle, Francija, Apvienotā Karaliste), bet vēl citas ierindojās tālu aizmugurē (Amerikas Savienotās Valstis, Itālija). Kopumā vidējais OAP/IKP industrializēto valstu vidū 2005. gadā bija sasniedzis vien 0,25\%, kas bija tālu no ANO mērķa (OECD, 2005). Vairāk nekā desmit gadu vēlāk OAP/IKP ipatsvars palielinājās līdz 0,32 \% no IKP, bet saraksts ar lielākajām donorvalstìm, izṇemot Nỉderlandi, saglabājās tāds pats.

oECD pārskati liecina, ka iedzīvotāji kopumā ir pozitīvi noskaņoti pret atbalsta sniegšanu jaunattīstības valstīm. Lìdzịi secinājumi izriet arī no Eiropas iedzivotāju aptaujām. Balstoties uz Eirobarometra 2015. gadā veiktās aptaujas rezultātiem, 89\% respondentu Eiropā piekrita, ka ir svarīgi palīdzēt jaunattistïbas valstim (Eurobarometer, 2015). Tomēr sabiedrïbas izpratne par attīstỉbas palīdzību ir nepietiekama. 2004. gadā vairākums aptaujāto amerikāṇu ticēja, ka ārvalstu palīdzībai viṇu valdỉba tērēja $24 \%$ no valsts budžeta, kamēr eiropieši lēsa, ka ārējās palīdzibas apjoms svārstās no 5 līdz 10\% no valdību izdevumiem (PIPA, 2001; ESAO, 2003). Patiesībā gan ASV, gan ar ES valdību izdevumi attīstïbas sadarbībai nepārsniedz $1 \%$ no valsts budžeta (iznēēmums ir Luksemburga).

2015. gadā Latvijā attīstības sadarbỉbai veltija tikai o,09\% no kopprodukta. No tiem 90\% (19,6 miljoni) eiro tika novirziti daudzpusējai palīdzībai (iemaksas Eiropas Savienības budžetā, ANO ağentūrās un citās starptautiskajās organizācijās un iniciatīvās), bet 10\% (1,99 miljoni eiro) divpusēju atbalstu dotāciju veidā tika pieškirti nevalstiskajām organizācijām, stipendijām zināšanu apmaiņai. Gruzija, Moldova un Ukraina ir trīs valstis, kuras gūst lielāko labumu no Latvijas divpusējā atbalsta tādās jomās kā tiesiskums, izglìtība un humānā palīdzỉba. Lai arī kopš finanšu un ekonomikas krīzes Latvijas oficiālās attīstības palīdzỉbas apjoms ir pieaudzis, iespēja sasniegt plānotos 0,33\% no IKP ir maz ticama.

Saskanā ar speciālo Eirobarometra pētījumu 2014. gadā iedzivotāji Latvijā bija vismazāk pozitīvi noskanoti pret attīstỉbas palīdzību $(67 \%$ 
salīdzinājumā ar ES vidējo rādītāju - 89\%). No aptaujātajiem eiropiešiem Latvijas iedzīvotāji vismazāk piekrita apgalvojumam, ka jaunattīstības valstu cinnai ar nabadzību ir jābūt vienai no galvenajām ES prioritātēm (48\%). Latvijas iedzivotāji bija otrie visskeptiskāk noskaņotie pret apgalvojumu, ka jaunattīstỉbas valstu cinnai pret nabadzību ir jābūt vienai no galvenajām prioritātēm nacionālās valdības līmenī. Latvijas respondenti salīdzinoši vismazāk piekrita apgalvojumam, ka palīdzība jaunattīstības valstīm ir efektīvs veids, kā risināt migrācijas problēmu (57\%) (Eurobarometer, 2015). Lìdzīgi kā citās valstīs, jaunāki respondenti (vecumā no 15 līdz 24 gadiem) bija pozitīvāk noskaņoti par attīstības palīdzỉbas jautājumiem nekā gados vecāki iedzīvotāji (Eurobarometer, 2015). Sabiedrības atbalsts attīstības palīdzībai kopumā tiek raksturots kā plašs, taču sekls, jo sabiedrība lielākoties nezina, ko attīstības palīdzība ietver, un neuzskata, ka tai jābūt prioritārai (Leiserowitz, 2005).

Baltijas valstu vidū Latvijā salīdzinoši visvairāk iedzīvotāju (64\%) piekrīt apgalvojumam, ka starptautiskās organizācijas atṇem pārāk daudz varas valdỉbai. Igaunijā tā domā $58 \%$, bet Lietuvā $-46 \%$ iedzìvotāju (ISSP, 2010). Tajā pašā laikā $40 \%$ piekrìt, ka noteiktu problēmu risināšanai, piemēram, vides piesārṇošanas novēršanai, starptautiskajām organizācijām (ANO, ES, Pasaules Veselības organizācijai) ir tiesības piemērot savus līdzekḷus. Vērtējot nacionālo interešu nozīmi starptautiskajās attiecībās, redzams, ka kopš 1995. gada par vairāk nekā 10\% pieaudzis to iedzivotāju ipatsvars, kas uzskata, ka Latvijai būtu jāseko savām interesēm, pat ja tas novestu pie konflikta ar citām valstīm. 1995. gadā tam piekrita $44 \%$ iedzīvotāju, bet 2010. gadā jau $57 \%$. Lietuvā tā domāja 38\%, bet Igaunijā-48\% respondentu (ISSP, 1995, 2010).

VIDE Sabiedribas attieksme pret vidi ietver attieksmi pret attiecibām starp cilvēkiem un dabu, vides problēmām un attieksmi pret vides aizsardzību. Salīdzinājumā ar ierobežotiem datiem par iedzivotāju attieksmi pret ekonomisko attīstību pētijumi par attieksmi vides jautājumos ir niansētāki. Dati par attiecībām starp cilvēkiem un dabu tika pētîti ar vairāku jautājumu palīdzību WVS aptaujā. Viens no šiem jautājumiem ir saistīts ar cilvēku un dabas līdzāspastāvēšanu. Lielākā dạ̦a respondentu (76\%) visā pasaulē piekrita, ka cilvēkiem vajadzētu sadzīvot ar dabu, un tikai $19 \%$ atzina, ka cilvēkiem drīzāk vajadzētu apgūt dabu. Starp tiem, kas vairāk piekrita apgalvojumam, ka cilvēkiem vajadzētu sadzīvot ar dabu, bija respondenti, kuri dzīvoja Japānā un Ziemelamerikā. Tie, kas piekrita, ka cilvēkiem vajadzētu apgūt dabu, dzīvoja Jordānijā, Vjetnamā, Tanzānijā un Filipinnās (Leiserowitz, 2005). Nepieciešams vairāk pētijumu, lai noteiktu kultūras, sociālos un ekonomiskos iemeslus, kas veido šādu attieksmi. Globālie pētijumi, piemēram, Environics GlobeScan, apliecina, ka sabiedrības bažas par vides problēmu kopumā ir pietiekami aktuālas (Environics International (GlobeScan), 2000). Tas atspoguḷojas arī sabiedrības atbalstā vides aizsardzībai pretstatā ekonomiskās izaugssmes un darbvietu radī̌̌anai, samierinoties arī ar darbvietu zaudējumu. Šis konstatējums uzskatāmi parādījās 2002. gada G7 valstu WVS apsekojumā. 1995. gadā vairākums iedzīvotāju (62\%) visā pasaulē vienojās par nodokḷu palielināšanu, ja naudu izmantotu, lai novērstu kaitējumu videi, bet 33 \% bija pret šādu risinājumu (Inglehart et al., 2000). Lielākajā daḷā valstu sabiedrība atbalsta to, ka tiktu palielinātas Apvienoto Nāciju Organizācijas pilnvaras aizsargāt zemes klimatu, taču būtiski mazāk (apmēram 10\%) iedzìvotāju ir personiski iesaistijjušies ar vidi saistìtu problēmu risināšanā.

Vai iedzīvotāju attieksme pret kolektīviem jautājumiem ietekmē arī ikdienas dzìvē ìstenotās aktivitātes? Lai to pārbaudìtu, pētnieki centušies izzināt iedzīvotāju patēriṇa uzvedību, kas veicina noteiktu produktu vai preču zìmju patērinu vai arì izvairišanos no to patērina. $28 \mathrm{ES}$ valstīs cilvēki ir samazinājuši vai plāno samazināt apkuri, gaisa kondicionēša$\mathrm{nu}$, apgaismojumu un sadzives elektroenerğijas patēriņu (Eurobarometer, 2002). Ja izlases ğeogrāfiskais aptvērums tiek paplašināts, tiek iegūti atšḳirīgi rezultāti. Lai arī respondenti Ziemelamerikā un Rietumeiropā galvenokārt izvairās no noteiktiem produktiem vai zīmoliem vides apsvērumu dēl, Latīṇamerikā, Austrumeiropā un Vidusāzijā šāda rīcība ir mazāk izplatīta (Globescan, 2002). Iespējams, ka šĩs atškirïbas skaidro atškirīgais ienākumu līmenis un arī strukturāli faktori, piemēram, pārstrādes un enerǵijas taupišanas sistēmu efektivitāte, noteikta regulējuma trūkums minētajās valstīs. 44 \% respondentu ar augstiem ienākumiem bija gatavi maksāt par videi draudzīgu automašīnu, bet tikai $10 \%$-valstīs ar zemiem iedzīvotāju ienākumiem (Globescan, 2002). Iedzīvotāji mazāk vēlas atbalstìt videi draudzīgu dzìvesveidu, ja viṇiem būtu jāmaksā vairāk par benzīnu. Šajā jautājumā iedzivotāju atbildes vismaz dạẹeji diktē loğiskais pamatojums par to, kā tiks iztērēti vinuu papildu maksājumi. Pat valstīs ar augstu ienākumu līmeni tikai $28 \%$ respondentu bija gatavi maksāt $10 \%$ vairāk par benzinnu, ja nauda tika izmantota gaisa piesārṇojuma samazināšanai (Globescan, 2002). 2011., 2013. un 2015. gadā tika veikti îpaši Eurobarometer pētijumi, lai novērtētu iedzīvotāju bažas un rīcību klimata pārmaiṇu jomā. Šie pētijumi liecina, ka aptuveni puse Eiropas iedzivotāju ir ierindojusi klimata pārmainas kā trešo svarīgāko globālo problēmu. Nabadzība, badošanās un dzeramā ūdens trūkums tika uzskatītas par visnozīmīgākajām, bet ekonomiskā situācija par otro nozìmigāko problēmu (EK, 2015).

Latvijas iedzìvotāji mazāk satraucas par klimata pārmainām nekā citu Eiropas valstu iedzivotāji. Kaut arī lielākā daḷa eiropiešu uzskatīja, ka valstu valdībām ir jāuzṇemas galvenā atbildība par klimata pārmaiṇu novēršanu, lielākā daḷa Latvijas iedzivotāju domā, ka atbildībai galvenokārt jāgulstas uz vides aizsardzības grupu pleciem (EK, 2015). Šis konstatējums ir uzmanības 
1. tabula. ES28 un Latvijas iedzīvotāju attieksme pret nozīmīgākajām globālajām problēmām, t. sk. klimata pārmaiṇām 2013.-2015.gadā (\%)

\begin{tabular}{|c|c|c|c|c|}
\hline Problēma & & ES28 & LV 2015 & $\begin{array}{l}\text { Izmainas } \\
\text { LV'13-'15 }\end{array}$ \\
\hline \multirow{5}{*}{$\begin{array}{l}\text { Nopietnākā } \\
\text { problēma, ar } \\
\text { kuru saskaras } \\
\text { visa pasaule }\end{array}$} & Nabadzība, bads un dzeramā ūdens trūkums & 30 & 23 & -3 \\
\hline & Starptautiskais terorisms & 19 & 14 & 4 \\
\hline & Ekonomiskā situācija & 16 & 16 & -16 \\
\hline & Klimata pārmaiṇas & 15 & 7 & -2 \\
\hline & Bruņoti konflikti & 9 & 26 & 17 \\
\hline \multirow{5}{*}{$\begin{array}{l}\text { Kas atbildīgs } \\
\text { par klimata } \\
\text { pārmaiṇu } \\
\text { novēršanu ES }\end{array}$} & Valstu valdības & 42 & 33 & -1 \\
\hline & Uzṇēmēji un rūpniecība & 35 & 34 & -7 \\
\hline & Eiropas Savieniba & 35 & 18 & -2 \\
\hline & Pats personigi & 19 & 11 & 1 \\
\hline & Vides aizsardzības grupas & 14 & 28 & 5 \\
\hline \multirow{6}{*}{$\begin{array}{l}\text { Personiski } \\
\text { veiktās } \\
\text { darbības, kas } \\
\text { saistītas ar } \\
\text { vidi un cīṇu } \\
\text { pret klimata } \\
\text { pārmaiṇām }\end{array}$} & Atkritumu šķirošana un pārstrāde & 74 & 45 & 12 \\
\hline & $\begin{array}{l}\text { Iegādāties mazāk vienreizējās lietošanas } \\
\text { priekšmetu }\end{array}$ & 51 & 44 & 8 \\
\hline & Vienreiz lietojamo priekšmetu samazināšana & 57 & 44 & 8 \\
\hline & $\begin{array}{l}\text { Pirk vietēji ražotu un sezonas pārtiku, kad } \\
\text { vien iespējams }\end{array}$ & 49 & 64 & 16 \\
\hline & $\begin{array}{l}\text { Jaunas sadzives tehnikas izvēle, } \\
\text { pamatojoties uz energoefektivitāti }\end{array}$ & 42 & 50 & 26 \\
\hline & Videi draudzīgas transporta alternatīvas & 36 & 51 & 24 \\
\hline
\end{tabular}

vērts, jo starp ieinteresētajām pusēm, kurām ir ievērojamas rīcỉbas pilnvaras un kapacitāte, vides aizsardzības grupas acīm redzami nevar būt pietiekami ietekmīgas, lai risinātu tik sarežğìtu fenomenu kā klimata pārmainas. Iespējamais izskaidrojums Latvijā varētu būt cieša vides jautājumu sasaiste ar klimata pārmainām. Eirobarometra aptaujas arì liecina, ka no 2013. gada ir ievērojami mainījušās ilgtermiṇā risināmo problēmu prioritātes. Latvijas gadijumā šìs pārmaiņas radās, reağêjot uz mainīgo ǵeopolitisko situāciju ar pieaugošo vardarbību Ukrainā un pieaugošo spriedzi starp Krievijas un Eiropas politiku. Iespējams, ka šĩs izmaiņas ǵeopolitiskajā situācijā Eiropā tiek atspoguḷotas pieaugošās bažās par bruṇotiem konfliktiem. Kaut arī klimata pārmainas nav starp Latvijas iedzīvotāju lielākajām bažām, fiksējams ievērojams pieaugums darbỉbās, kuru mērḳis ir apkarot vai mazināt klimata pārmaiñas. Lielākais pieaugums vērojams, pērkot vietējos un sezonas produktus, kā arī energoefektīvus produktus. Tas liek domāt, ka Latvijas iedzìvotāji arvien vairāk saista savu personisko rīcību ar klimata pārmainām.

PATĒRIN̦š Demogrāfiskās prognozes liecina, ka 2030. gadā pasaules iedzīvotāju skaits sasniegss 8,3 miljardus. Ekonomiskā izaugssme visblīvāk apdzìvotajās pasaules dạ̦ās (Indijā, Āzijā) jau ievērojami ietekmē pasaules ekosistēmu, jo, pieaugot ienākumiem, arī iedzīvotāju patēriṇa līmenis palielinās. Tomēr iedzìvotāju skaits palielinās arī mazāk pārtikušajos pasaules reğionos. Viens no septiniem cilvēkiem joprojām dzīvo absolūtā nabadzībā, un kopumā aptuveni 782 miljoni iedzīvotāju cieš no hroniska bada. Tieši tāpēc aptaujās par patērinu parādās pretrunigi rezultāti. No vienas puses, lielākā dala pasaules iedzivotāju ir vienisprātis, ka pārmērīgs patērinš rada apdraudējumu cilvēku kultūrai un videi. Tā, piemēram, $54 \%$ iedzīvotāju domā, ka mazāk uzmanības vajadzētu pievērst naudai un materiālajam labumam, un lielākā dala iedzīvotāju arī piekrīt, ka svarīgākais dzīves mērkis ir iegūt vairāk brīvā laika, ko pavadīt ar ğimeni (Inglehart et al., 2000). Tajā pašā laikā $65 \%$ respondentu arī uzskata, ka tērēt naudu sev un savai ǵimenei viniem sagādā lielāko prieku. Šo viedokli apstiprināja 74 \% iedzivotāju no valstīm ar zemu IKP. Turpretim valstīs ar augstu IKP šādi domājošo ipatsvars bija mazāks $-58 \%$ ). Lielākajai daḷai pasaules iedzīvotāju joprojām ir loti izteikti materiālie motivi, neskatoties uz to, ka Rietumu u. c. sabiedrìbās pastāv kultūras normas pret pārmērīgu izdevumu apbrīnošanu. Liela dạ̦a Eiropas un Ziemeḷamerikas iedzīvotāju nepiekrita apgalvojumam, ka citu cilvēku apbrīnošana viṇu mantas un īpašuma dēḷ ir svarīga, savukār 54-59\% respondentu no Latinnamerikas, Āzijas un Eirāzijas šim apgalvojumam piekrita (Globescan, 2002).

Materiālais patēriņš ir fenomens, ar kuru pārbaudīt, vai iedzivotāju vides vērtības un attieksme pret vidi izpaužas vinu uzvedỉbā. Saskan ar GlobeScan pētijuma rezultātiem $36 \%$ respondentu no 20 attīstitajām un 
2. tabula. Latvijas iedzīvotāju gatavība personiski «maksāt»» par vides aizsargāšanu 2000. un 2010.gadā (\%, kas pilnīgi piekrìt vai piekrīt attiecīgajam apgalvojumam)

\begin{tabular}{lrr}
\hline & 2000 & 2010 \\
\hline Būtu gatavs maksāt augstākas cenas & 22 & 11 \\
\hline Būtu gatavs maksāt augstākus nodokḷus & 17 & 8 \\
\hline Būtu gatavs samazināt savu dzìves līmeni & 6 & 7 \\
\hline Nav jēgas vides labā darìt to, ko es varu, ja vien citi nedara tāpat & 32 & 36 \\
\hline
\end{tabular}

(ISSP 2000, 2010)

jaunattīstības valstīm atzina, ka vides aizsardzības apsvērumu dēl ir izvairījušies no kāda produkta vai zīmola patērēšanas (Globescan, 2002). Kā norāda Mišela Miheleti (Michele Micheletti), patēriņš faktiski kḷuvis par mūsdienu politiskās aktivitātes formu, kurā iedzīvotāji apzināti pērk vai boikotē noteiktas preču zīmes tāpēc, ka atbalsta vai neatbalsta noteiktas korporatīvās prakses, kas kaitē videi, vai arì izmanto lētu darbaspēku (Micheletti, 2003). Tādējādi globālās attīstības kontekstā politiskais patēriṇš būtu uzskatāms par «globālās pilsonības» formu.

Latvijā apzinātā preču patēriṇā iesaistās samērā maz iedzivotāju. Starptautiskās sociālās aptaujās (International Social Survey ProgrammeISSP) redzams, ka izteikts vairums Latvijas iedzivotāju nevēlas ziedot savu materiālo labklājību, lai aizsargātu vidi. Laika gaitā šì tendence pastiprinās. 2000 . gadā $22 \%$ respondentu piẹ̦āva, ka būtu gatavi maksāt augstāku cenu, lai aizsargātu vidi, bet 2010. gadā šādu iespēju pielāva vairs tikai 11\% (sk. tabulu). Nedaudz pieaudzis arī to iedzivotāju ipatsvars, kuri uzskata, ka nav jēgas aizsargāt vidi, ja vien citi nedara tāpat. 2010. gadā tā domāja aptuveni $36 \%$ respondentu.

Saskanā ar SUSTINNO 2015. gadā veikto aptauju tikai aptuveni $13 \%$ iedzìvotāju bija boikotējuši noteiktas valsts vai uzṇēmuma produktus, lai izteiktu politisku attieksmi, un aptuveni tāda pati daḷa bija pirkusi produktus no citām valstīm un uznēmumiem, lai izteiktu savu politisko attieksmi (sus TINNO, 2015). Šāda informācija par politiskā patērnieciskuma līmeni sabiedrībā ḷauj pastiprināti pievērsties attiecību starp patēriṇu un tradicionālajām politiskās aktivitātes formām analīzei, taču dažādu patērnieciskuma sociālekonomisko aspektu izzināšanai būtu nepieciešami padziḷināti pētījumi.
Kopumā Latvijas iedzīvotājiem raksturīga samērā protekcioniska nostādne attiecībā uz patēriṇu, taču, analizējot iedzīvotāju atbildes uz vairākiem jautājumiem ISSP aptaujās, rezultāti nešķiet viennozīmīgi. Gandrīz divas trešdalas Latvijas iedzivotāju piekrīt apgalvojumam, ka valstij ir jāierobežo importa preces, lai aizsargātu vietējo ekonomiku (73\%); salīdzinājumam - Lietuvā šãdi domā $46 \%$, bet Igaunijā - krietni mazāk - 36\% iedzìvotāju. Trīs Baltijas valstu vidū Latvijas iedzīvotāji izceḷas arī ar vislielāko skepsi pret lielo starptautisko kompāniju kaitējošo ietekmi uz vietējo uznēmējdarbību (Latvija $-64 \%$, Lietuva $-51 \%$, bet Igaunija $-46 \%$ ). Tajā pašā laikā arī salīdzinoši daudz Latvijas iedzīvotāju (67\%) atbalsta to, ka ārzemniekiem būtu jālauj iegādāties zeme (Lietuvā-60\%, Igaunijā-42\%) (ISSP, 2010).

ienākumu nevienlīdzība un nabadzība Pēdējo četru gadu desmitu laikā ienākumu sadale pasaulē ir krasi mainijusies. Pasaules nabadzīgāko iedzīvotāju ienākumi ir pieauguši, un nabadzība ir samazinājusies ātrāk nekā jebkad agrāk cilvēces vēsturē. Galvenās pārmaiṇas iesākās 2o. gadsimta beigās, kad ievērojamu progresu sāka demonstrēt Dienvidaustrumāzijas ekonomikas (Lakner \& Milanovic, 2013). Tomēr ienākumu nevienlīdzība atšķiras ne tikai starp valstīm, bet arī to iekšienē. Tūkstošgades sākumā WVS respondentiem tika uzdots jautājums, vai viṇi dod priekšroku lielākām ienākumu atškirībām vai individuālu pūlu stimulam. Tam piekrita $47 \%$ no 72 valstu iedzivotājiem, bet $33 \%$ norādijja, ka vēlas dot priekšroku ienākumu vienlīdzīgākai sadalei (World Value Survey, 2003). Tas norāda, ka, neskatoties uz pastāvošo nevienlīdzību, sabiedrỉba atbalsta individuālās konkurences vērtības (Leiserowitz, 2005). Nepieciešams vairāk pētijumu, lai saprastu, kā konkurences un vienlīdzības principi izpaužas dažādās sabiedrībās, t. sk. arî Latvijā.

TEHNOLOG̣ıJAs Tehnolog̣iju inovācijas var piedāvāt risinājumus daudzām globālām problēmām, piemēram, pārtikas trūkumam, enerğijas ražošanai, klimata pārmaināan un veselības stāvokḷa uzlabošanai. Nav pārsteidzoši, ka GlobeScan un WVS aptauju rezultāti liecina par pārliecinošu sabiedrības atbalstu tehnoloǵijām. Valstīs, kurās ir mazāks IKP, pastāv lielāka vienprātỉba jautājumā, ka mūsdienu tehnoloğiju priekšrocības atsver to radītos riskus. Tas ir pretstatā turigāāo valstu iedzīvotāju skeptiskākajai attieksmei pret tehnoloǵijām. Sabiedrības attieksme pret atjaunoto enerǵiju, kodolenerợiju, kịmisko pesticīdu izmantošanu lauksaimniecībā un biotehnoloğiju tikai nesen izraisijusi pētnieku interesi. Aptaujās konstatēts, ka Eiropā kopumā pastāv sabiedrības atbalsts atjaunojamās enerğijas risinājumiem, piemēram, saules, vēja un biomasas izmantošanai, taču atbalsts kịmisko pesticīdu lietošanai turpina samazināties. Aptuveni $70 \%$ respondentu no G7 valstīm izteica iebildumus pret genenētiski modificētiem 
3. tabula. Respondenti, kuri piekrīt, ka ir loti svarīgi vai diezgan svarīgi mācīt par noteiktiem jautājumiem skolās $(\%, N=1000)$

\section{Jautajums}

Īpatsvars

Globalizācija un savstarpējā saistība

Migrācija

Migrācija

Pašreizējie kari un konflikti

Vide un ilgtspējiga attīstība

Pārtikas pieejamība un patēriņš

Attiecības starp attīstītajām un jaunattīstības valstīm

Politiskā un pilsoniskā līdzdalība

Cilvēktiesības

Dažādas kultūras, etniskās un reliğiskās grupas

Mediju izmantošana

Starptautiskās organizācijas

Pieeja izglītībai pasaulē

(SUSTINNO 2015)

aug̣̣iem un dārzeṇiem veselības un vides problēmu dēḷ. Sabiedrības atbalsts konkrētiem tehnoloğiju izmantošanas veidiem atškiras. Lai arī $78 \%$ pasaules iedzivotāju atbalsta biotehnologíiju izmantošanu jaunu zālu izstrādei, tikai $34 \%$ atbalstijja tās izmantošanu ǵenētiski modificētas pārtikas ražošanai (Globescan, 2002). Acimredzot iedzīvotāju kompetences uzlabojumi tehnolog̣iju lomā prasa turpināt pētijumus par dažādu tehnoloğiju uztveri un to izmantošanas iespējām.

Kopumā pētijumi par dažādiem globalizācijas un ilgtspējas aspektiem norāda uz noteiktām attieksmju pretrunām pasaules iedzīvotāju vidū. Kaut arī cilvēki bieži pārṇem ekoloğiski orientētus uzskatus par pasaules sociālajiem, vides un ekonomiskajiem izaicinājumiem, vinu attieksmes pret noteiktām vērtībām joprojām ir antropocentriskas. Lielākā dạ̣a cilvēku uzskata, ka mazāk uzmanības jāpievērš materiālajām vērtỉbām, taču piekrīit arī tam, ka patērinš ir viens no svarīgākajiem dzives priekiem. Neraugoties uz plašu sabiedrības atbalstu atjaunojamai enerǵijai, tā joprojām veido tikai nelielu daļu globālajā enerớijas patēriṇā.

Tà kā sabiedrība uztver ilgtspējigas attīstìbas tematus kā nozìmīgus, sniegtajās atbildēs noteikti pastāv arī zināms sociālās vēlamỉbas procents. Latvijā veiktā globālās izglìiības jomas pētỉjumā vērojams, ka lielākā dạ̣a respondentu uzskata-ir svarīgi mācìt bērnus par globālajām tēmām skolās. Par īpaši nozìmīgām tika atzìtas cilvēktiesības, piekluve izglìiỉbai, videi un ilgtspèjiga attīstiba. Aptuveni $80-90 \%$ respondentu uzskatijja, ka ir ḷoti svarīgi vai diezgan svarīgi, lai minētās tēmas tiktu mācītas skolās (SUSTINNO, 2015). Sīkāku pārskatu par globālās attīstības tēmu mācīšanu skolās sniedz tabula.

Pētnieki norāda uz vairākām barjerām starp iedzìvotāju attieksmēm un uzvedību ilgtspējīgas attīstības kontekstā (Leiserowitz, 2005). Pirmã barjera ir saistìta ar noteiktas attieksmes virzienu, spēku un prioritāti, bet otrā vairāk ar individuālām spējām noteiktās attieksmes pārvērst darbībā. Šis spējas ir saistītas ar pieejamo laiku, turību, lasītprasmi u. c. faktoriem. Trešā barjera ir strukturālāka un ietver noteiktu institucionālu faktoru kopumu, piemēram, noteikta regulējuma esamību, subsīdijas, infrastruktūru, tehnologíijas - faktorus, kas var sekmēt noteiktu iedzivotāju rīcibu ilgtspējigas attīstības jomā. Ceturtā barjera ir saistīta ar plašāku sociālo, ekonomisko un politisko kontekstu, piemēram, enerǵijas cenu, interešu grupu aktivitāti noteiktās jomās, vēlēšanu ciklu, dziḷi sakṇotām kultūras un reliğiskajām attieksmēm (Leiserowitz, 2005). Minēto barjeru dēḷ plaisas pārvarēšana starp to, ko cilvēki domā, un to, ko viṇi dara, ir liels izaicinājums.

\section{Metodologija}

MODELIS Šajā pētījumā pārbaudītais modelis balstās uz pieṇēmumu, ka iedzīvotāju globālā identitāte ir saistìta ar vinu vērtībām un attieksmēm, kā arī ar demogrāfiskiem faktoriem - vecumu, ienākumiem, izglitību un tautību.

ATKARīcıle mainīcıe Lai novērtētu Latvijas respondentu globālo orientāciju, mainigais, kas visprecizāk atspogulo respondenta subjektivo sajūtu par to, cik viņšs/viṇa jūtas cieši saistìts(-a) ar pasauli, tika izvēlēts kā atkarīgais mainīgais. Respondentiem tika lūgts novērtēt savu atbildi 5 punktu Laikerta skalā par to, cik cieši vini jūtas saistīti ar tuvāko apkārtni, pilsētu, savu reǵionu, savu valsti (Latviju), Krieviju, Baltijas valstīm, Eiropu un 
pasauli. Tika izmantots arī papildu mainīgais, kas raksturo respondenta interesi par notikumiem tuvākajā apkārtnē, savā pilsētā, reğiionā, valstī, Krievijā, Baltijas valstīs, Eiropā un pasaulē.

NEATKARĪGIE MAINīGIE Šā pētijuma neatkarīgie mainīgie ir balstīit uz Šaloma Švarca vērtību modeḷa vērtībām, kā arī R. Inglhārta materiālajām un postmateriālajām vērtībām (Schwartz, 2012; Inglehart, 2008). Š. Švarca vērtību modelī rādītāji katrai no 10 vērtību grupām tika izteikti vērtībās no -1 (negatīvs) līdz 1 (pozitîvs). Materiālisma līmenis/postmaterālisms, atbilstoši R. Inglhārta metodolog̣ijai, tika noteikts, balstoties uz respondenta atbildēm par to, kādas prioritātes valstij būtu jāievieš nākamajos 10 gados, kā arī sērijveida jautājumiem par materiālajām/nemateriālajām, racionālajām/tradicionālajām vērtību orientācijām. Šo jautājumu mērkis bija pozicionēt katru respondentu materiālā/pēcmateriālā rangaa 6 grādu skalā robežās no stipras materiālās orientācijas $(-200)$ līdz spēcīgai postmateriālajai orientācijai (+3oo). Kā neatkarīgi mainīgie tika izmantoti arì respondentu demogrāfiskie rādîtāji, piemēram, dalībnieka vecums, ienākumi, izglìtības līmenis un tautība. Iedzivvotāji, jo îpaši jaunattīstības valstīs, aizvien vairāk apzinās lielo uznēemumu un korporāciju postošās sekas pasaules resursu izmantošanā un tāpēc izvairās no dažādu zīmola preču pirkšanas. Tādē šajā pētîjumā paredzēti arī trīs jautājumi par politisko patērinuu. Pirmais jautājums noskaidro, vai respondenti ir boikotējuši (boycotting) preces vai zimolus, lai paustu savu politisko attieksmi? Otrais un trešais jautājums attiecas uz t. s. baikotēšanu (buycotting) jeb apzinātu preču un pakalpojumu iegādāšanos no Latvijas uzṇēmējiem vai arī no uzṇēmējiem no citās valstīs.

\section{Rezultāti un diskusija}

IDENTIFIKĀCIJA UN INTERESE PAR NOTIKUMIEM PASAULĒ Lìdzigi kā vairumā valstu, arī Latvijā iedzīvotāji kopumā vairāk jūtas piederīgi valstij, savai pilsētai un pašvaldībai. Pēc ISSP 2010. gadā veiktās aptaujas rezultātiem, cieši un loti cieši piederīgi savai valstij jutās $79 \%$ iedzìvotāju, bet savai pilsētai vai pašvaldibai- $68 \%$. Krietni mazāk juta ciešu sasaisti ar savu kontinentu $-26 \%$. Interesanti, ka Latvijā vairāk nekā Igaunijā un Lietuvā iedzīvotāji piekrita apgalvojumam, ka jūtas vairāk kā pasaules pilsoṇi nekā konkrētas valsts pilsoṇi (25\%). Igaunijā tā domāja $21 \%$ respondentu, bet Lietuvā tikai $16 \%$ (ISSP, 2013).

Rezultāti, kas atspoguḷo respondentu sajūtu par vinu saistību ar dažādu teritoriālo līmeṇu dzìves telpām, kopumā norāda uz valstsnācijas nozīmi, jo lielākā dala respondentu pirmām kārtām izjūt ciešu saikni ar savu valsti. Tālāk seko pilsēta un tuvējāa apkaime. Tikai apmēram trešdala respondentu
4. tabula. Latvijas iedzīvotāju interese par notiekošo un subjektīvā saistība ar noteiktām dzīves telpām 2010. un 2015. gadā $(\%, N=1000)$

\begin{tabular}{|c|c|c|c|}
\hline & $\begin{array}{r}\text { Loti liela un } \\
\text { liela interese } \\
\text { par... }\end{array}$ & $\begin{array}{r}\text { Jūtas cieši vai } \\
\text { loti cieši saistìts } \\
\text { ar... (2010) }\end{array}$ & $\begin{array}{r}\text { Jūtas cieši vai } \\
\text { loti cieši saistits } \\
\text { ar...(2015) }\end{array}$ \\
\hline Tuvāko apkārtni, savu apkārtni & 79 & 52 & 71 \\
\hline Savu pilsētu & 85 & 58 & 75 \\
\hline Savu reğionu & 72 & 50 & 58 \\
\hline Savu valsti Latviju & - & 59 & 82 \\
\hline Krieviju & 49 & - & 12 \\
\hline Baltijas valstīm & 67 & 37 & 35 \\
\hline Eiropu & 64 & 26 & 35 \\
\hline ASV & 33 & - & - \\
\hline $\begin{array}{l}\text { Citiem pasaules reǵiioniem (Āfrika, } \\
\text { Austrālija, Āzija, Dienvidamerika) }\end{array}$ & 28 & - & - \\
\hline Pasauli & NA & NA & 26 \\
\hline
\end{tabular}

Avoti: dati par 2011.gadu no SKDS veiktā vispārējās iedzivotāju aptaujas. Dati par 2015.gadu no SUSTINNO projekta aptaujas (SUSTINNO, 2015).

jutās cieši saistīti ar Eiropu un vēl mazāk (26\%) - ar pasauli. Salīdzinājumā ar 2010. gadu respondentu subjektīvā saistība ir pastiprinājusies. Palielinājies to respondentu ipatsvars, kuri izjūt ciešu saistỉbu ar savu apkārtni, pilsētu/ ciemu un valsti. Tomēr palielinājies arì to respondentu îpatsvars, kuri jūtas cieši saistīti ar Eiropu. Tāpēc nevar apgalvot, ka globalizācijas apstāklos būtu vērojama viennozīmìga saiknes pavājināšanās ar nacionālā un vietējā līmeṇa dzīves telpu. Subjektīvā saikne ar noteiktām teritorijām nav izslēdzoša, lai arī kopumā respondenti tomēr norāda uz ciešāku subjektîvo sasaisti ar tām dzives telpām, kas atrodas tiem blakus. 
5. tabula. Identificēšanās korespondence respondentiem, kuri cieši/

loti cieši identificējas ar noteiktām teritorijām un reǵioniem $(\%, N=1000)$

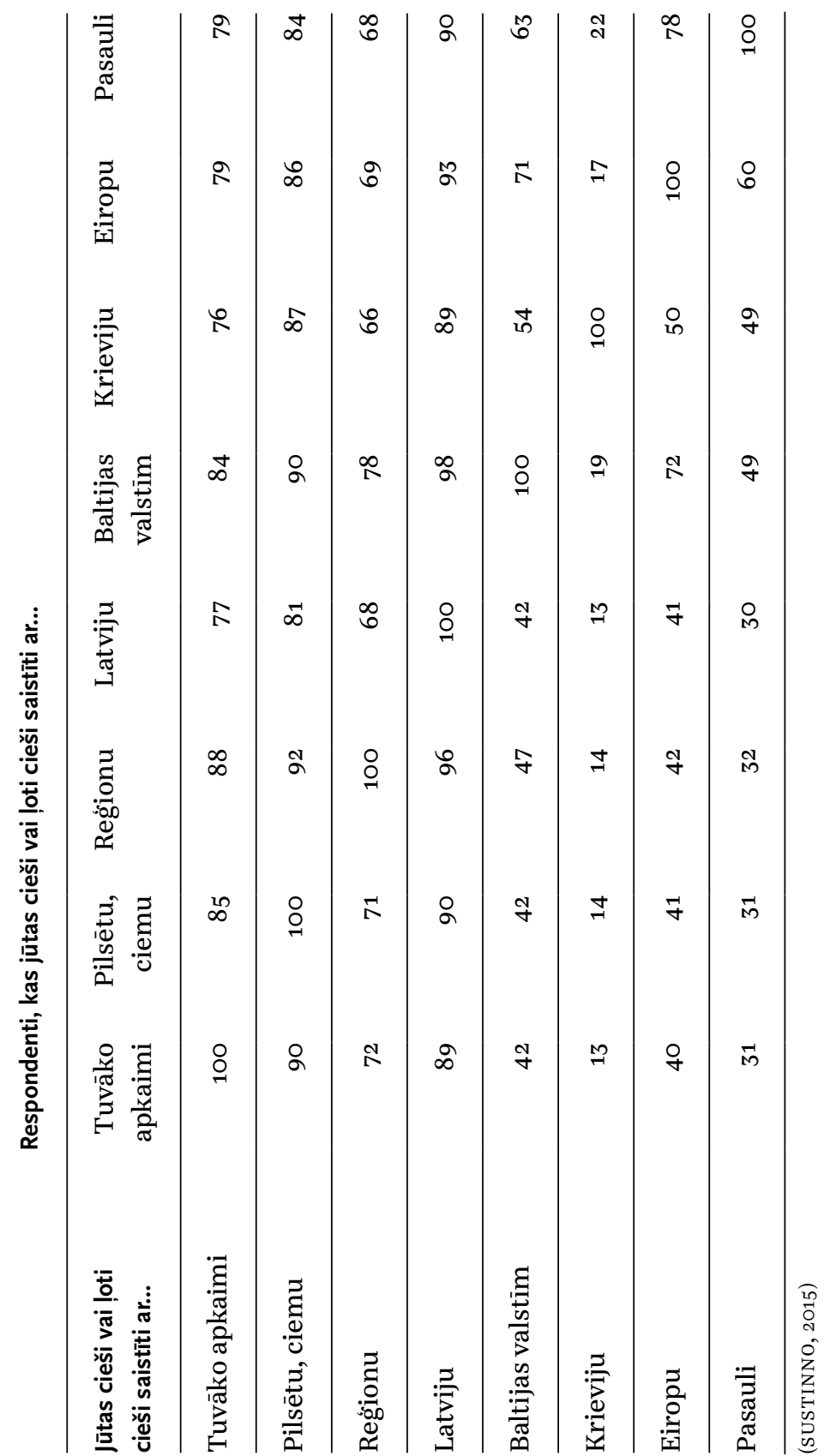

Respondentu subjektivā saistība ar noteiktajām dzives telpām ir saistìta arī ar vinu interesi par notikumiem šajās dzìves telpās. Respondenti, kas jūtas cieši saistīti ar savu pilsētu, pauž interesi par notikumiem savā pilsētā. Tomēr interese par notikumiem Eiropā, Krievijā un Baltijas valstīs ir lielāka nekā subjektīvā saistība ar šīm dzives telpām. Tas liecina, ka iedzīvotāji tomēr vēlas apzināties notikumus šajos reǵionos. Lai gan globalizācija, šķiet, kliedē tradicionālo telpas un laika dimensiju, geeogrāfiskais tuvums joprojām ir nozīmīgss, jo iedzīvotāii izjūt lielāku saistību ar tām teritorijām, kas atrodas geoogrāiski tuvāk. Interesanti, ka starp tiem, kuri identificējuši diezgan spēcīgu un loti spēcìgu saikni ar pasauli, ir mazāk tādu, kuriem ir liela interese par tuvāko apkārtni, norisēm pilsētā un reǵionā. Starp šãdiem respondentiem ir vairāk tādu, kas interesējas par to, kas notiek Eiropā, Amerikas Savienotajās Valstīs un citos pasaules reğionos.

Respondentu identifikācijas korespondences analīze rāda, ka lielākā dala respondentu izjūt ciešu saistību ar savu apkārtni (71\%), pilsētu $(75 \%)$ un reǵionu (58\%). Analīze atklāj dažu respondentu identitāšu pārklāšanos. Var konstatēt, ka kopumā respondenti, kuri izjūt ciešu saikni cieši ar Baltijas valstīm, Krieviju un Eiropu, izjūt ciešu saikni arī ar pasauli, savukārt respondenti, kuri izjūt ciešu saikni ar kaimiņvalstīm, pilsētu, reğionu un Latviju, izjūt mazāk spēcīgu saikni ar pasauli un Krieviju. Starp tiem, kuri identificējas ar Eiropu, 60\% identificējas ari ar pasauli. Savukārt tikai 31\% respondentu, kuri stingri vai loti stingri identificējas ar savu pilsētu, stipri identificējas arī ar pasauli un Eiropu (41\%). Šie rezultāti liecina, ka starp vietēja mēroga un globāla mēroga identitātēm pastāv zināma polarizācija. Starp tiem, kuri cieš identificējas ar Baltijas valstīm un Krieviju, ir arī vairāk tādu, kuriem izteikta arī identificēšanās ar pasauli. Tādējādi $49 \%$ respondentu, kuri cieši un ḷoti cieši identificējas ar Baltijas valstīm un Krieviju, arī atzina, ka vini stingri identificējušies ar pasauli un Eiropu (72\%), savukārt tikai 30-32\% respondentu, kas identificējušies ar apkārtni, pilsētu, savu reǵionu un Latviju, arī cieš vai ḷoti cieši identificējušies ar pasauli. Tādējādi vietējām/nacionālajām identitātēm un globālajām identitātēm ir nedaudz atškirīgs, bet ne ekskluzivs raksturs. Pat starp tiem, kuri stipri vai loti stipri identificējušies ar pasauli, 90\% identificējas arī ar Latviju. Tas ir pretrunā ar tēzi, ka globalizācija iznī cina nacionālo identitāti.

VĒRTīBAS Aptaujas rezultāti liecina, ka Latvijas sabiedrībā plaši pārstāvētas transcendences vērtības, kas ietver universālismu, sociālo taisnigumu, mieru pasaulē, viedumu. Tomēr arī saglabāšanas vērtības ir plaši izplatītas. Šis vērtības ietver atbilstību, tradīcijas un drošību. Vērtību grupu vidējie rādītāji svārstijiās no augstākās uz zemāko - labdarība $(0,590)$, drošība $(0,458)$, universālisms $(0,429)$, atbilstība $(0,420)$ un pašrealizācija $(0,408)$, kam sekoja stimulēšana $(-0,379)$, hēdonisms $(-0,242)$ un sasniegumi 
(-o,298). Šìs vērtības bija mazāk izplatītas respondentu vidū. Varas vērtību grupa bija vismazāk izteikta. Tās vidējais rādītājs bija tikai -o,801. Postmateriālās orientācijas rezultāti rāda, ka Latvijas sabiedrību nevar sadalīt grupās ar stingru postmateriālu vai materiālu orientāciju. Tikai apmēram $15 \%$ no visas izlases bija raksturīgi rādītāji, kas liecināja tikai par materiālu orientāciju, un apmēram $38 \%$ nebija ne skaidra materiāla, ne postmateriāla orientācija. Lielākā daḷa (47\%) respondentu varētu tikt pieskaitìta pie grupas ar izteiktu postmateriālu orientāciju. $1 \%$ respondentu postmateriālā orientācija bija īpaši spēcīgi izteikta.

Nav bütiskas korelācijas starp respondentu globālo identifikāciju un vērtībām. Tādējādi nevar pienemt, ka cilvēki, kas jūtas tuvāki pasaulei vai Eiropai, ietilpst grupās ar viendabīgām vērtỉbām, piemēram, universālismu vai labvēlību. Nepastāv cieša saikne starp subjektīvo tuvību ar noteiktām vietām/reğioniem un noteiktām vērtību grupām. Rezultāti liecina par vāju, taču būtisku korelāciju starp tradicionālo orientāciju un ciešāku piederības sajūtu savam reğionam. Tas nozìmē, $k a$ respondenti ar tradicionālāku noslieci mēdz büt mazāk orientēti uz Eiropu un pasauli (o,113, $p=0,05)$. Šis secinājums atbilst R. Inglhārta pienēmumam, ka identificēšanās ar valsti vairāk raksturỉga iedzivotājiem ar tradicionālu vērtību orientāciju.

Pētījumā atklājas ciešākas sakarības starp subjektīvās saistības izjūtu un demogrāfiskajiem mainīgajiem. Kā sagaidāms, identificēšanās ar Latviju ir izteiktāka starp gados vecākiem respondentiem $(0,118, p=0,05)$. Iedzīvotāji, kas nav latvieši, vairāk identificējas ar Krieviju un mazāk - ar Baltijas valstīm $(-0,217, p=0,05)$. Iedzīvotāji ar augstāku ienākumu līmeni un izglìtîbu jūtas ciešăk saistîti ar Latviju $(-0,109, p=0,01)$, Baltijas valstīm $(-0,146, p=0,05)$, Eiropu $(-0,122, p=0,05)$ un pasauli $(-0,105, p=0,05)$. Kopumā respondentu saistỉba ar pasauli nav tik lielā mērā atkarīga no vinu vecuma, dzimuma, tautỉbas, bet gan tieši no viṇu ienākumiem $(-0,105$, $p=0,95)$. Respondenti ar lielākiem ienākumiem izjūt ciešāku saistību ar pasauli $(-0,105, p=0,05)$. Šāds secinājums nav pārsteidzošs, jo tieši ienākumi un izglìīiba ir spēcīgi integrācijas veicinātājfaktori. Iespējams, ka augstāki ienākumi un izglìtība veicina sociālo mobilitāti, kas nostiprina globālo identifikāciju.

Lai gan respondentu identificēšanās nav tieši atkarīga no vinuu vērtību orientācijas, pastāv ciešāka saikne starp respondentu vērtỉbu orientāciju un vinu interesi par notikumiem noteiktos reǵionos. Respondenti ar izteiktām vērtībām š. Švarca drošỉbas, universālisma un varas vērtỉbu grupā pauž lielāku interesi par pasaules dalāām nekā respondenti ar izteiktām vērtību orientācijām labvēlības, pašrealizācijas un hēdonisma grupā. Interesanti, ka respondenti ar izteiktāku pēcmateriālu orientāciju neizrāda lielāku interesi par dažādām pasaules dạ̦ām, tostarp arì par pasākumiem reǵionos ārpus Eiropas, piemēram, Āziju, Āfriku, Dienvidameriku vai Austrāliju (-o,o76, $p=0,95)$. Tas liecina, ka postmateriālu orientāciju ne vienmēr var saistīt ar lielāku interesi par notikumiem pasaulē.

Respondenti ar izteiktākām drošības vērtībām izrāda lielāku interesi par notikumiem Eiropā $(-0,105, p=0,95)$ un Krievijā $(-0,103, p=0,95)$, bet respondenti ar izteiktākām stimulācijas vērtībām $(0,129, p=0,95)$ un sasniegumu vērtībām $(0,1010, p=0,95)$, šķiet, mazāk interesējas par notikumiem Krievijā. Respondenti ar izteiktām tradicionālām vērtībām izrāda lielāku interesi par notikumiem savā reğionā $(-0,143, p=0,95)$. Respondenti ar izteiktām universālisma vērtībām vairāk interesējas par notikumiem savā pilsētā, $(-0,104, p=0,95)$, savā reğionā $(-0,122, p=0,95)$, Krievijā $(-0,182, p=0,95)$ un citos pasaules reǵionos $(-0,101, p=0,95)$. Respondenti ar izteiktām varas vērtībām mazāk interesējas par notikumiem savā pilsētā $(0,125, p=0,95)$ un reğionā $(0,165, p=0,95)$.

Šie rezultāti jāinterpretē ar zināmu piesardzību, jo lielākajā daḷā gadījumu uzrādìtās korelācijas ir diezgan vājas. Škiet, ka universālisma vērtības patiešām veicina intereses ārpus vietējās apkārtnes, tomēr dati liecina arī par to, ka universāluma vērtỉbas ir plaši izplatîtas starp tiem, kas izrāda lielāku interesi arī par notikumiem savā pilsētā. Tas parāda, ka ir iespējams domāt par globalizāciju kā par procesu, kas ietver sarežğìtu mijiedarbību starp vietējo un globālo vērtību orientāciju. Nav pārsteidzoši saskatīt korelāciju starp drošības vērtībām un notikumiem Eiropā un Krievijā. Iespējams, ka spriedzes pastiprināšanās starp Krieviju un Ukrainu aktualizējusi nepieciešamību pēc iedzīvotāju iekšējās drošības.

POLITISKAIS PATÉRNIECISKUMS Tikai apmēram $13 \%$ Latvijas respondentu bija boikotējuši vai iegādājušies dažus produktus, lai izteiktu savu politisko attieksmi, bet aptuveni $41 \%$ respondentu atzina, ka pēdējo piecu gadu laikā vini ir pirkuši vietējos produktus, lai izteiktu savu politisko attieksmi. Vietējo produktu patēriņš bija nedaudz vairāk izplatīts starp tiem, kuri cieši identificējās ar savu reğionu $(0,132, p=0,05)$, Latviju $(0,116, p=0,05)$ un Baltijas valstìm (o,147, $p=0,05)$.

Nav būtiskas korelācijas starp politiskā patērnieciskuma uzvedību un iedzīvotāju identificēšanos. Kā sagaidāms, respondenti ar spēcīgāku postmateriālu orientāciju bija nedaudz vairāk iesaistijušies preču boikotēšanā $(-0,101, p=0,05)$. Cilvēki ar augstāku postmateriālu orientāciju arī bija vairāk iegādājušies vietējos produktus, lai parādītu savu politisko attieksmi $(-0,125, p=0,05)$. Lai gan boikotēšanas vai pirkšanas gadijumi ir reti, šḳiet, ka tie ir plašāk izplatīti respondentu vidū ar zemāku vidējo ienākumu līmen $(-0,140, p=0,05)$ un zemāku izglìtības lïmeni $(-0,194, p=0,05)$. Kopumā šķiet, ka politiskā patērnieciskuma uzvedība ir vairāk saistīta ar demogrāfiskajiem faktoriem nekā ar respondentu vērtībām un identificēšanos. Daži no tā dēvētajiem postmateriālisma teorijas elementiem nerada apstiprinājumu, 
6. tabula. Respondentu interešu, identitātes un patēriṇa paradumu korelācijas Š. Švarca vērtïbu grupās

\section{Drošība Konformitāte Tradīcija Labvēiliba}

\begin{tabular}{|c|c|c|c|c|c|}
\hline \multirow{8}{*}{$\begin{array}{l}\text { Interesējas par } \\
\text { notikumiem }\end{array}$} & Tuvākajā apkaimē & 0,00 & $-0,027$ & $-0,037$ & $-0,019$ \\
\hline & Pilsētā, ciemā & $-0,033$ & $-0,037$ & $-0,063^{*}$ & $-0,071^{*}$ \\
\hline & Savā reğionā & $-0,040$ & $-0,046$ & $-0,143^{* *}$ & $-0,072^{*}$ \\
\hline & Baltijas valstiss & $-0,065^{*}$ & $-0,059$ & $-0,057$ & $-0,021$ \\
\hline & Krievijā & $-0,103^{* *}$ & $-0,029$ & $-0,091^{* *}$ & $-0,044$ \\
\hline & Eiropā & $-0,105^{* *}$ & 0,002 & 0,027 & $-0,005$ \\
\hline & ASV & $-0,052$ & 0,009 & $-0,011$ & 0,039 \\
\hline & $\begin{array}{l}\text { Citos pasaules } \\
\text { reğionos (Āzijāa, Āfrikā, } \\
\text { Dienvidamerikā, Austrālijāa }\end{array}$ & $-0,090^{* *}$ & 0,026 & $-0,032$ & $-0,071^{*}$ \\
\hline \multirow{8}{*}{$\begin{array}{l}\text { Jūtas cieši } \\
\text { saistitts ar... }\end{array}$} & Tuvāko apkaimi & $-0,028$ & $-0,065^{*}$ & $-0,062^{* *}$ & $0,001^{* *}$ \\
\hline & Pilsētu, ciemu & $-0,052$ & $-0,046^{* *}$ & $-0,018^{*}$ & $-0,002^{* *}$ \\
\hline & Savu reğionu & $-0,047$ & $-0,024$ & o,o79** & $-0,048^{*}$ \\
\hline & Savu valsti-Latviju & $-0,058$ & $-0,068^{* *}$ & $-0,068$ & $-0,030^{*}$ \\
\hline & Krieviju & 0,025 & $-0,045^{* *}$ & $-0,056^{*}$ & $-0,055^{*}$ \\
\hline & Baltijas valstim & $-0,013$ & $0,003^{* *}$ & $0,068^{* *}$ & $0,061^{*}$ \\
\hline & Eiropu & 0,030 & $0,031^{* *}$ & $0,113^{* *}$ & $0,099^{*}$ \\
\hline & Pasauli & $0,085^{* *}$ & $0,036^{* *}$ & $0,113^{* *}$ & $0,072^{* *}$ \\
\hline \multirow{3}{*}{$\begin{array}{l}\text { Politiskais } \\
\text { patêrnieciskums }\end{array}$} & Boikotējis produktus & $-0,029^{* *}$ & 0,043 & 0,037 & 0,028 \\
\hline & Pircis vietêjos produktus & $-0,041^{* *}$ & $-0,034^{* *}$ & $-0,044$ & 0,028 \\
\hline & $\begin{array}{l}\text { Pircis produktus no } \\
\text { citām valstim }\end{array}$ & $0,045^{* *}$ & 0,005 & 0,007 & 0,054 \\
\hline
\end{tabular}

** Pîrsona korelācija ir nozimiga pie limeña -o,o1 (2-tailed).

* Pîrsona korelācija ir nozimiga pie limeṇa -o,o5 (2-tailed).

\begin{tabular}{|c|c|c|c|c|c|c|}
\hline Universālisms & Pašrealizācija & Stimulācija & Hēdonisms & Panākumi & Vara & $\begin{array}{r}\text { Post- } \\
\text { materiālisms }\end{array}$ \\
\hline$-0,043$ & 0,060 & $-0,007$ & $-0,001$ & $-0,013$ & $0,093^{* *}$ & 0,034 \\
\hline$-0,104^{* *}$ & $0,067^{* *}$ & o,046 & 0,028 & 0,032 & $0,125^{* *}$ & 0,011 \\
\hline$-0,122$ & 0,058 & 0,059 & 0,011 & $0,115^{* *}$ & $0,165^{* *}$ & 0,020 \\
\hline$-0,062$ & $-0,002$ & $-0,098^{* *}$ & $0,072^{* *}$ & 0,056 & 0,021 & $-0,019$ \\
\hline$-0,182^{* *}$ & 0,017 & $0,129^{* *}$ & $0,098^{* *}$ & $0,101^{* *}$ & $0,085^{* *}$ & $-0,063^{*}$ \\
\hline$-0,118^{* *}$ & 0,023 & 0,034 & $0,080^{*}$ & 0,029 & 0,035 & $-0,076^{*}$ \\
\hline$-0,086^{* *}$ & $-0,009$ & 0,014 & $0,082^{* *}$ & 0,037 & $-0,011$ & $-0,066^{*}$ \\
\hline$-0,101^{* *}$ & $-0,006$ & 0,047 & o, $071^{*}$ & $0,072^{*}$ & 0,058 & $-0,076^{*}$ \\
\hline 0,011 & $0,033^{* *}$ & $0,045^{* *}$ & $-0,013^{* *}$ & $0,042^{* *}$ & 0,033 & $-0,005^{* *}$ \\
\hline$-0,036^{* *}$ & $-0,043^{* *}$ & $0,035^{* *}$ & $-0,0 \circ 2^{*}$ & $0,007^{* *}$ & $0,073^{* *}$ & 0,048 \\
\hline$-0,041^{* *}$ & $0,016^{* *}$ & o,o68 & $0,016^{* *}$ & $0,064^{* *}$ & $0,053^{* *}$ & $-0,078^{* *}$ \\
\hline$-0,044^{* *}$ & $0,067^{* *}$ & $0,073^{* *}$ & 0,067 & o,o29* & $0,025^{* *}$ & $-0,071^{* *}$ \\
\hline$-0,084^{* *}$ & $0,050^{* *}$ & $0,024^{* *}$ & $0,092^{*}$ & 0,030 & $0,014^{* *}$ & $0,075^{* *}$ \\
\hline $0,020^{* *}$ & $0,006^{* *}$ & $-0,042^{* *}$ & $0,025^{* *}$ & $-0,055^{* *}$ & $-0,051^{* *}$ & $-0,08 o^{* *}$ \\
\hline $0,074^{*}$ & $0,000^{* *}$ & $-0,095^{* *}$ & $-0,005^{* *}$ & $-0,097^{* *}$ & $-0,109^{* *}$ & $-0,032^{* *}$ \\
\hline $0,004^{* *}$ & $0,026^{* *}$ & $-0,128^{* *}$ & $-0,019^{* *}$ & $-0,048^{* *}$ & $-0,061^{* *}$ & $0,004^{* *}$ \\
\hline$-0,021$ & $-0,043^{* *}$ & $0,014^{*}$ & $0,011^{* *}$ & $0,005^{*}$ & $-0,043^{* *}$ & $-0,101$ \\
\hline$-0,034^{* *}$ & $-0,002^{* *}$ & $-0,022^{* *}$ & $\mathrm{O}, \mathrm{O} 71^{* *}$ & $0,026^{* *}$ & $0,061^{* *}$ & $-0,125$ \\
\hline $0,026^{* *}$ & $-0,018^{*}$ & $-0,057$ & $0,009^{* *}$ & $-0,049^{* *}$ & $-0,002^{* *}$ & $0,020^{* * *}$ \\
\hline
\end{tabular}


7.tabula. Demogrāfisko faktoru un ienākumu korelācijas ar iedzīvotāju identificēšanos un politisko patērnieciskumu

\begin{tabular}{|c|c|c|c|c|c|c|}
\hline & & Dzimums & Vecums & Tautība & lenākumi & Izglîtíba \\
\hline \multirow{8}{*}{$\begin{array}{l}\text { Jūtas cieši } \\
\text { saistits ar... }\end{array}$} & Tuvāko apkaimi & $-0,075^{*}$ & $-0,030$ & 0,070* & $-0,043$ & $-0,008$ \\
\hline & Pilsētu, ciemu & $-0,089^{* *}$ & $-0,036$ & o,o31 & $-0,037$ & $-0,037$ \\
\hline & Savu reǵionu & $-0,061$ & $-0,095^{* *}$ & $0,094^{* *}$ & $-0,049$ & $-0,041$ \\
\hline & Savu valsti-Latviju & $-0,038$ & $-0,118^{* *}$ & $0,099^{* *}$ & $-0,109^{* *}$ & $-0,135^{* *}$ \\
\hline & Krieviju & 0,022 & $-0,040$ & $-0,217^{* *}$ & $-0,015$ & 0,040 \\
\hline & Baltijas valstìm & 0,020 & $-0,036$ & $0,114^{* *}$ & $-0,146^{* *}$ & $-0,144^{* *}$ \\
\hline & Eiropu & 0,040 & 0,055 & 0,052 & $-0,122^{* *}$ & $-0,162^{* *}$ \\
\hline & Pasauli & $0,066^{*}$ & $0,064^{*}$ & o,056 & $-0,105^{* *}$ & $-0,080^{*}$ \\
\hline \multirow[t]{3}{*}{$\begin{array}{l}\text { Politiskais } \\
\text { patērnieciskums }\end{array}$} & $\begin{array}{l}\text { Boikotējis } \\
\text { produktus }\end{array}$ & 0,002 & $-0,023$ & $-0,014$ & $-0,140^{* *}$ & $-0,194^{* *}$ \\
\hline & $\begin{array}{l}\text { Pircis vietējos } \\
\text { produktus }\end{array}$ & $-0,071^{*}$ & $-0,106^{* *}$ & $0,075^{*}$ & $-0,085^{* *}$ & $-0,127^{* *}$ \\
\hline & $\begin{array}{l}\text { Pircis produktus } \\
\text { no citām valstìm }\end{array}$ & 0,033 & $-0,014$ & $-0,044$ & $-0,005$ & $-0,040$ \\
\hline
\end{tabular}

** Pìrsona korelācija ir nozīmiga pie lìmeṇa -o,o1 (2-tailed).

* Pirsona korelācija ir nozimisa pie limena -0,05 (2-tailed).

piemēram, tas, ka politiskajā patērnieciskumā vairāk iesaistās gados jaunāki iedzīvotāji ar augstāku ienākumu līmeni un izglītību.

\section{Noslēgums}

8. tabula. Korelācija starp iedzīvotāju identitāti

\section{un politisko patērnieciskumu}

\begin{tabular}{lcrr}
\hline $\begin{array}{l}\text { Jūtas cieši } \\
\text { saistits ar... }\end{array}$ & $\begin{array}{r}\text { Boikotējis } \\
\text { produktus }\end{array}$ & $\begin{array}{r}\text { Pircis vietējos } \\
\text { produktus }\end{array}$ & $\begin{array}{r}\text { Pircis produktus } \\
\text { no citām valstimm }\end{array}$ \\
\hline Tuvāko apkaimi & $0,033^{* *}$ & $0,021^{* *}$ & $0,008^{* *}$ \\
\hline Pilsētu, ciemu & $0,043^{* *}$ & $0,067^{* *}$ & $0,006^{*}$ \\
\hline Savu reğionu & 0,045 & $0,132^{* *}$ & $0,017^{* *}$ \\
\hline Savu valsti-Latviju & $-0,071^{* *}$ & $0,116^{* *}$ & $0,044^{*}$ \\
\hline Krieviju & $-0,017^{* *}$ & $-0,044^{*}$ & 0,036 \\
\hline Baltijas valstim & $0,097^{* *}$ & $0,147^{* *}$ & $0,045^{*}$ \\
\hline Eiropu & $0,096^{* *}$ & $0,073^{* *}$ & $0,047^{* *}$ \\
\hline Pasauli & $0,087^{* *}$ & $0,050^{* *}$ & $0,062^{* *}$ \\
\hline
\end{tabular}

** Pîrsona korelācija ir nozīmiga pie lïmena -o,o1 (2-tailed).

* Pirsona korelācija ir nozimigga pie limeña -o,o5 (2-tailed).

iedzīvotāju attieksmē un vērtībās, sekmējot atvērtākas, globālas un visaptverošas vērtïborientācijas stiprināšanu. Sabiedrïbas attieksmju izpēte attiecībā uz ilgtspējību ir parādījusi iedrošinošus rezultātus, piemēram, pieaugošu sabiedrỉbas izpratni par nepieciešamību orientēt valstu politiku uz ilgtspējīgas attīstïbas mērḳiem. Taču pētỉjumi atklāj ievērojamas atšḳirības starp cilvēku attieksmi un uzvedỉbu.

No politikas veidošanas skatpunkta ir divas pieejas, lai mazinātu plaisu starp iedzīvotāju rīcību un attieksmi globālās attīstỉbas jautājumos. Pirmā pieeja paredz vēl vairāk veicināt konkrētu attieksmju nostiprināšanos, kas sabiedrībā jau ir izteiktas. Otrai pieejai jākoncentrējas uz iedzīvotāju spēju palielināšanu, lai attieksmes būtu iespējams pārvērst darbībās. Pētijjuma rezultāti akcentē abu pieeju dzivotspēju un veido pamatu precīzākiem globālās orientācijas spēka prognozēšanas modeliiem.

Šis pētijums uzskatāms par mēǵinājumu noskaidrot respondentu globālo orientāciju, attiecinot to uz iedzivotāju subjektivo identificēšanos ar telpām nacionālās valsts robežās un ārpus tās. Pētijuma rezultāti liecina, 
ka vērtības un attieksmes kopumā ir diezgan vāii globālas orientācijas faktori. Demogrāfiskie faktori, jo īpaši ienākumi un izglītỉba, vairāk ietekmē respondentu intereses un identifikāciju ar pasauli ārpus nacionālās valsts robežām. Respondenti ar lielākiem ienākumiem izjūt spēcīgāku saikni ar pasauli kopumā, ne tikai ar savu apkaimi, pilsētu, reớionu un valsti. Tādēl espējams, ka ienākumi ir noteicošs integrāciju veicinošs faktors ne tikai nācijvalstu, bet arī globālajā līmenī. Turpmākajos pētỉjumos, kas vērsti uz iedzivotāju globālās orientācijas izpēti, būtu jākoncentrējas uz demogrāfisko, kā arī sociālekonomisko faktoru nozīmes izpēti. Būtisks iedzīvotāju globālo orientāciju spēcinošs faktors varētu būt arī ārpus valsts pavadìtais laiks. 


\section{Politiskā atsvešinātība un anomija mūsdienu Latvijā}

Inta Mierina
Divdesmit piecus gadus pēc neatkarības atgūǔšanas Latviju joprojām raksturo Eiropas mērogam augsts korupcijas un nepotisma līmenis, savukārt pilsoniskās sabiedrības attīstību kavē iedzivotāju politiskais cinisms, apātija un neuzticēšanās valdỉbai. Vienlaikus lỉdzšinējie pētījumi norāda uz augstu sociālās atstumtības risku dažādās grupās, sociālo fragmentētîbu, sociālās uzticēšanās un empātijas trūkumu sabiedrībā. Daži zinātnieki uzskata šo situāciju par komunistiskā režìma mantojumu, bet citi norāda uz pārmainu perioda negatìvo ietekmi. Šì nodala papildina līdzšinējo pētniecisko literatūru un piedāvā «postmodernā stāvokḷa» sociālo diagnozi, izmantojot klasiskos atsvešinātības un anomijas jēdzienus. Pētijuma socioloǵiskais ietvars lauj aplūkot pagātnes mantojuma pārvarēšanas grūtības plašākā vērtību un iekšējo normu kontekstā.

Sociālā fragmentētība un politiskā atsvešinātība

Kamēr sociālā kapitāla literatūrā pausts satraukums par sabiedrības atomizāciju un sociālo sadrumstalotību, kas var kavēt cilvēkus kolektīvi rīkoties, pētijumi politikas laukā kā problemātisku uzsver postkomunisma valstu pilsoṇu politisko atsvešinātỉbu. Iedzivotājiem ir tendence neuzticēties citiem sabiedrỉbas locekḷiem un politiskajai elitei.

Miko Lāgerspecs (Lagerspetz, 2009) par postkomunisma kultūras raksturīgāko iezīmi uzskata «pilsoṇi pret valsti» mentalitāti. Līdzīgus secinājumus izdarījusi arī Brigita Zepa (1999), pētot situāciju Baltijas valstīs. Viṇa apgalvo, ka ḷoti vājas ir vertikālās saites, kas varētu veicināt attiecības starp sabiedrību un politisko eliti, un var novērot izteiktu politisko atsvešinātību. «Valsts tiek uztverta kā kaut kas tāls un abstrakts, kas nepakḷaujas indivìdu gribai un kontrolei» (Zepa, 1999, 32). Ilze Koroḷeva un Ritma Rungule (Koroleva \& Rungule, 2006) secina, ka tieši pirms un pēc nacionālās neatkarības atjaunošanas 1991. gadā cilvēki Latvijā jutās vienoti ar valdību un parlamentu, jo viṇiem bija kopīgs mērḳis - izveidot neatkarīgu un bagātu valsti. Pēc tam korupcija un ekonomiskās problēmas atsvešināja cilvēkus no politiskās elites un politikas kopumā. Arī Ivars Ijabs (2007) atzīmē, ka uzticēšanās politiskajām institūcijām Latvijā ir ārkārtīgi neliela pat salīdzinājumā ar citām Centrāleiropas un Austrumeiropas valstīm un ka tikai viena piektdala pilsonu apzinās politikas nozimi savā dzivē. Politiskās atstumtības kultūra turpināja attīstities pat pēc komunistiskā režìma krišanas (Mierina \& Cers, 2015). Dažādu iemeslu dēl konfliktējošas valsts un sabiedrības attiecības var uzskatìt par «neefektivām» vai pat disfunkcionālām (Woolcock \& Narayan, 2000).

Aptuveni divas trešdalas Latvijas iedzīvotāju neuzskata, ka vini varētu kaut ko darìt, lai mainītu valdības pieņemto lēmumu vai pat ietekmētu paš valdỉbas līmenī pienemtos lēmumus (Šūpule, 2005). Latvijas iedzivotāju vidū visai izplatīts ir uzskats, ka politiku nosaka dažas ekonomiskās grupas un 
ka reti tiek nemtas vērā visu cilvēku intereses. Turklāt vairums uzskata, ka nav iespējams neko darît, ja valdība vai pašvaldība pieṇem lēmumus, kas ir pretrunā ar pilsoṇu interesēm (BISS, 2005). Demokrātiskā teorija pieṇem, ka politisko atsvešināšanos un politisko neuzticēšanos viegli var novērst partiju konkurence un aizstāšana pēc vēlēšanām. Tomēr, ja cilvēki neredz atšķirības starp partijām, atsvešināšanās izjūta saglabāsies. Kā liecina pētijumi, aptuveni divas trešdaḷas Latvijas iedzīvotāju nav saistīti ar partijām vai nejūtas tuvi nevienai no partijām (ISSP 2006).

Politiskā uzticēšanās un politiskās ietekmes spējas vērtējums dažādās sabiedrības grupās ievērojami atšḳiras, un tas zināmā mērā norāda uz atsvešinātības cēloniem. Kā rakstijis Rasels Daltons (2004), fakts, ka pieaug neapmierinātība starp iedzīvotājiem ar zemāku ienākumu līmeni, varētu liecināt par to, ka marginalizētie sabiedrības locekḷi aizvien vairāk tiek atsvešināti no politiskās sistēmas, un tas savukārt norāda uz Jirgena Hābermāsa prognozēto vēlīnā kapitālisma krīzi (Bobbio \& Bellamy, 1987). Citi pētnieki norāda, ka tieši jaunākie, labāk izglìtotie, postmateriālistiskie pilsoṇi ir neapmierināti ar demokrātijas darbību un arvien uzstājigāăk pieprasa demokrātijas procesa paplašināšanos (Inglehart, 1990, 1997; Dalton, 2004). Pētijumi liecina, ka postkomunisma valstīs politiskā atsvešinātība īpaši raksturīga jauniešu grupā (Mierina, 2014). Jaunieši kritiski vērtē politiskos lïderus un politisko procesu, kā arī izrāda nelielu interesi par formālo politiku un tradicionālajām politiskajām aktivitātēm (Henn et al., 2002; Kovacheva, 2005; Jennings \& Stoker, 2004; Mierina, 2014). Tas sasaucas ar citās valstīs pētnieku konstatēto faktu, ka tradicionālā politika vairs nespēj pietiekami uzrunāt un aizraut jauniešus.

Sociālā atomizācija jeb sašḳeltỉba ir vēl viena postkomunisma valstīm raksturīga iezìme, jo daudzi zinātnieki norāda uz zemo sociālā kapitāla līmeni (Paldam \& Svendsen, 2000). Saskanā ar holistisko perspektīvu sociālais kapitāls ir kolektīvs labums - sociālo struktūru un sociālo attiecỉbu kopums, kas veicina kolektīvo rīcību (Coleman, 1990). Kā teicis Kristians Grūtaerts (Grootaert, 1998), tã ir «līme», kas satur sabiedrību kopā. Sociālā kapitāla būtỉba izpaužas neformālās vērtībās un normās, attiecībās un attieksmē, kas atvieglo sociālo mijiedarbību un noved pie labākas sabiedrības ekonomiskās, politiskās un sociālās funkcionēšanas (Putnam et al., 1993; Coleman, 1990; Fukuyama, 1996, 2001). Šì pieeja ir saistita ar politikas zinātni un socioloợiju, bet tā ir attīstīta arī sociālās ekonomikas teorijā. Balstoties uz šiem argumentiem, Roberts Patnems (Putnam, 2000) norāda, ka no sociālā kapitāla iegūst ne tikai atseviškas personas, bet arī grupa kopumā, piem., mazākas noziedzības un korupcijas, kā arī labākas pārvaldības formā. Vairākos pētijumos (Putnam et al., 1993; Fukuyama, 1996; Knack, 2002) zinātnieki ir nonākuši pie secinājuma, ka uzticēšanās un pilsoniskā sadarbỉba, kas ir galvenie sociālā kapitāla rādītāji, ir viennozīmīgi

saistīti ar aktīvāku ekonomisko darbību. Zinātnieki argumentē, ka sociālais kapitāls - normas un tìkli, kas lauj cilvēkiem kopīgi darboties (Woolcock \& Narayan, 2000), iespējams, ir viens no svarīgākajiem sabiedrības panākumus noteicošajiem faktoriem. Tomēr, kā norāda Kens Jovits (1992), sociālā sadrumstalotība pēcpadomju valstīs lika cilvēkiem - gan elitei, gan vienkāršiem pilsoṇiem - domāt galvenokārt par šaurām individuālām interesēm, nevis par lielāku sabiedrības labumu (sk. Howard, 2006).

\section{Anomija, atsvešinātība}

un tās dimensijas
Atsvešinātības termins sakṇojas Kārḷa Marksa teorijā, savukārt anomija ir termins, ko izveidojis Emīls Dirheims. Lai gan abiem konceptiem ir daudz kopigga (daudzas no to pamatā esošajām dimensijām pārklājas) un dažkārt jēdzieni pat tiek izmantoti kā savstarpēji aizvietojoši, šo autoru perspektīvas ir atškirīgas, un to pamatā ir loti atškirīga izpratne par sabiedrības problēmu pamatcēloṇiem un vēlamajiem risinājumiem (Hortons, 1964). Marksam atsvešinātības pamatā ir sabiedrības struktūra un ekonomiskās attiecības; tā ir cilvēku darbỉbas rezultāts. Dirheimam anomija ir pārpasaulīga, un to var pārvarēt ar kopīgiem sabiedrības centieniem. Asevedo (2005) sniedz visaptverošu abu jēdzienu analīzi un apgalvo, ka tie ir dažādi regulējuma ekstrēmi. Dirheims izjūt anomiju kā nepietiekama regulējuma rezultātu, savukārt, pēc Marksa domām, nosacỉjumi, kas uzlikti indivìdiem, atsvešina viṇus no sevis, kā arī no viṇu darba un neḷauj viṇiem pilnībā izmantot savu potenciālu.

Atsvešināšanās ir mazāk adekvātas sociālās kontroles trūkuma problēma nekā sociālās kontroles leğitimitātes problēma [..]. Anomija (anomie) koncentrējas uz kultūru sociālajā organizācijā. Atsvešinātībā uzmanība tiek pievērsta jebkādiem sociālajiem apstākliem, kas noškịir indivīdu no sabiedrības kā sevis paplašinājuma ar paša aktivitātes palīdzỉbu. Amonija koncentrējas uz škēršliem, kas traucē sabiedrïbas efektīvu funkcionēšanu; atsvešinātiba - uz

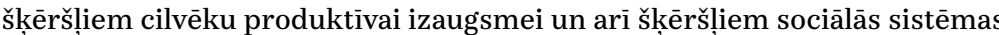
adaptĩām pārmaiņām (Horton, 1964, p. 676).

Svarīgi atzīmēt, ka pētnieki izmanto dažādus jēedzienus, lai aprakstītu anomijas dažādos aspektus. Srole, piemēram, nošḳir anomie un anomia.

Anomie attiecas uz strukturālo limmeni un apraksta regulējošo un integrējošo sociālo spēku vāiināšanos, kas rodas strauju sociālo pārmainu rezultātā vai ir strukturāli nenovēršami. Anomia atrodas individuālā līmenī un nozīmē normativāas orientācijas un kontroles pār situāciju un rīcības mērḳu zaudēšanu, kas tomēr ir atkarīga no sociāli anomiskās konstitūcijas (Legge et al., 2008). 
Lìdzịgi kā Lege un kolēǵi (2008), mēs pieņemam, ka anomie nozìmē zaudēt kognitīvo orientāciju un pārliecību rīkoties. «Neviens vairs nezina, kas ir iespējams un kas nav, kas joprojām šķiet piemērots un ko vairs nedara, kuras prasības un cerības ir aț̣autas un kuras ir pārmērīgas» (Durkheim, 1983, p. 288).

Kā minēts iepriekš, pat ja Marksa atsvešinātība un Dirheima anomija ir atšķirīgi jēdzieni, instrumentāli daudzas šo jēdzienu dimensijas pārklājas. Sīmans (Seeman, 1959) identificē piecas atsvešinātības dimensijas:

1) bezspēcība (nav kontroles pār notiekošo),

2) bezjēdzība (notikumu izpratne, iespējamie rezultāti utt.),

3) normu trūkums (normas ir sabrukušas vai ir neefektivas),

4) izolācija (kultūras un sabiedrības atsvešināšanās),

5) atsvešinātība no sevis - no kāda ideāla stāvokḷa (selfestragement).

Makaivers (MacIver, 1950) uzskata anomiju par atsvešinātỉbas apakštipu. Sìmana identificēto piecu atsvešinātības dimensiju empīrisks tests (Roberts, 1987; Korzeniowski, 1994; Skarżyńska \& Chmielewski, 1995) apstiprināja, ka bezspēcība un atsvešinātība no sevis ir divas galvenās atsvešinātỉbas dimensijas jeb aspekti. Anomija, atbilstoši Sīmanam, ir saistita ar normu trūkumu, bet labi redzams, ka tā ir saistīta arī ar daudzām citām atsvešinātības dimensijām. No Dirheima viedokla trauksme, sociālā izolācija un bezjēdzỉbas izjūta arī ir anomijas pazimes (Dean, 1961).

Pētijumi par postkomunistiskajām valstīm (Lytkina, 2015; Vingender, 2001; Pokrovski, 2000; Krivosheev, 2008; Buckley, 1997; Abbott \& Wallace, 2012) atklāj atšḳirīgu atsvešinātības vai anomijas struktūru dažādās valstīs.

Tajā pašā laikā ir cita literatūra, kas analizē politisko atsvešinātību. Arī politiskā atsvešinātība kā termins nāk no Kārla Marksa teorijas. Laika gaitā tam tika piešķirtas vairākas nozīmes, tomēr jēdziens «bezspēcība»indivìda brīvības un kontroles zaudējums - joprojām ir visizplatītākā izpratne par šo terminu (Seeman, 1959; Roberts, 1987). Korzenovskis (Korzeniowski, 1994) pamatoti apgalvo, ka atsvešināšanos var uztvert ne tikai kā pilsoṇu bezspēcības un atsvešinātības sajūtu no politiskās varas, bet arī kā objektīvu valdošās elites atsvešināšanos no sabiedrības. Dirheims uztvēra neuzticēšanos politiskajām institūcijām (kas îsteno sociālo kontroli) kā anomijas pazimimi. Srole (1956) savukārt par vienu no anomijas sastāvdalāām uzskata varas iestāžu atsaucīgumu pilsoṇu prasībām. Līdzịgu viedokli izsaka Devids Neters (Netter, 1957). Tomēr citi zinātnieki (piem., McDill \& Ridley, 1962) uzskata, ka tas, visticamāk, nenorāda uz anomiju, bet gan ir tās sekas. Turklāt vairākos pētijumos ir konstatēts, ka politiski atsvešinātie pilsoṇi ne vienmēr ir kognitivi apātiski un tiem bieži ir spēcigi politiskie uzskati, tomēr pierādījumi ir neviennozimīgi. Līdz šim brīdim nav skaidrs, vai politisko atsvešināšanos var uzskatìt tikai par vienu no anomijas izpausmēm vai dalu no plašākiem atsvešināšanās procesiem.

Lielākā daḷa literatūras definē politisko atsvešinātību kā 1) neuzticēšanos politiskajām institūcijām un 2) politiskās neefektivitātes sajūtu (Bowler \& Donovan, 2002; Kim, 2005; Catterberg \& Moreno, 2006; Paige, 1971). «Uzticēšanās» ir saistīta ar politikas rezultātiem (Almond \& Verba, 1989) un parasti atspoguḷo sajūtu, ka valdība darbojas cilvēku interesēs. Mūsdienu sabiedrībās politiskā uzticēšanās varētu būt vēl svarīgāka nekā starppersonu uzticēšanās, jo ḷoti individualizētās sabiedrībās pilsoṇi parasti paḷaujas uz iestādēm, nevis uz kolektīvu. Savukārt «efektivitāte» ir saistìta ar lēmumu pienemšanas procesu, un to parasti uztver kā pārliecību, ka individuāla rīcība var ietekmēt politiskos procesus (Kim, 2005). Direnco (DiRenzo, 1990, p. 31) norāda: «Atsvešināta persona ir indivīds, kurš, tā teikt, ir sabiedrībā, bet ne dala no tās.» Lìdz ar to nevar sagaidìt, ka šāds individs demonstrēs nozīmìgu pilsoniskuma pakāpi.

Daži politiskās atsvešināšanās rādītāji (Paige, 1971; Campbell et al., 1952; Kim, 2005) tieši sakrìt ar sociālās anomijas un atsvešinātỉbas indikatoriem (Seeman, 1959; Roberts, 1987). Šajā nodalāā mēǵināts saistìt šos jēdzienus, lai labāk saprastu, vai politisko atsvešināšanos var uzskatît tikai par vienu no anomijas izpausmēm. Ja tā, tas varētu norādīt uz nepieciešamìbu pārskatīt mūsu izpratni par politiskās atsvešināšanās saknēm, tādējādi nodrošinot labāku ieskatu sociālo un politisko attieksmju veidošanās mehānismos pēckomunisma valstīs.

Sociālais kapitāls bieži tiek operacionalizēts, izmantojot vispārējas uzticēšanās mērijiumu (Hamilton, 2006). Cita pieeja ir nodalīt tā strukturālos elementus, kas apraksta sadarbības tiklus, kuriem persona pieder (dalība organizācijās, asociācijās, tìklos), un kognitivos elementus, kas pamatā apraksta indivìda kooperativāa attieksmes (normas, vērtības, savstarpīgums, uzticēšanās) (Krishna \& Uphoff, 1999; Stolle, 2003). Paula Ballena un Dženija Oniksa (Bullen \& Onnix, 2000) piedāvā sešus sociālā kapitāla indikatorus dalība tīklos; savstarpējums; uzticēšanās; sociālo normu ievērošana; darbs kopịgam labumam; spējināšana. Pasaules Bankas sociālā kapitāla ieviešanas sistēmā tiek izmantoti šādi rādītāji: grupas un tîkli; uzticība un solidaritāte; kolektīvā rīcība un sadarbība; sociālā kohēzija un iekḷaušana; informācija un komunikācija. Sandra Franke (2005) apgalvo, ka daudziem pētijjumiem ir diezgan līdzịgs rādìtāju kopums, piemēram: uzticība, pilsoniskā iesaistīšanās, brīvprātīgais darbs, līdzdalība, ziedošana, noteikumu un pienākumu ievērošana. Daudzos gadījumos pastiprināti tiek uzsvērta normu un likumu ievērošana, uzticēšanās un solidaritāte, tolerance, sociālā kohēzija un ieklaušana un piederības sajūta grupai. Var secināt, ka vismaz daži sociālā kapitāla aspekti pārklājas ar to, kas literatūrā aprakstìts kā anomijai raksturīgās pazīmes (piem., normu trūkums). Šajā analīzē mūs ịpaši interesē sociālā kapitāla 
aspekti, kas saistīti ar sabiedrības sadrumstalotību un atomizāciju, it īpaši ar sociālo uzticēšanos.

Ir notikušas daudzas diskusijas par to, vai pastāv vairāk vai mazāk noziminga un konsekventa pozitiva korelācija starp politisko uzticēšanos un vispārēju uzticēšanos līdzcilvēkiem. Pastāv arī domstarpības par saistības virzienu. Daži (piem., Brehm \& Rahn, 1997) uzskata, ka politiskā uzticēšanās vairo sociālo uzticēšanos, savukārt citi (piem., Schyns \& Nuus, 2007) domā, ka saistïba ir pretēja.

Šìs nodaḷas mērḳi ir:

1) analizēt anomijas un atsvešinātỉbas struktūru Latvijā un tās saistỉbu ar politisko atsvešinātību un sociālo fragmentāciju;

2) aprakstìt atsvešinātības pakāpi un tās dažādās dimensijas Latvijā;

3) aprakstīt Latvijā valdošās vērtỉbas, izmantojot Ronalda Inglhārta un Šaloma Švarca vērtību skalas.

Saskaņā ar teoriju izvirzitas šādas hipotēzes:

H1. atsvešināšanās centrālie elementi ir bezspēcība un atsvešinātỉba no sevis;

H2. normu trūkums (anomijas kodola dimensija) ir dala no atsvešinātỉbas, un tā ir saistìta ar citām atsvešinātỉbas dimensijām;

H3. politiskā atsvešinātība un sociālā atstumtība ir atseviš̌şas dimensijas, kas ir saistītas ar atsvešinātību.

\section{Dati un metode}

Šajā nodalāā veiktā analizze ir balstīta uz reprezentatīvu Latvijas iedzīvotāju aptauju, kas tika veikta 2015. gadā kā dala no valsts pētijjumu programmas «Inovācija un ilgtspèjiga attīstìba: Latvijas pēckrīzes procesi globālā kontekstā» (SUSTINNo). Dati tika apkopoti tiešajās intervijās, un aptaujā piedalijāâs Latvijas iedzīvotāji vecumā no 18 lỉdz 74 gadiem. Anketā tika ieklauti 24 jautājumi, kas, pamatojoties uz iepriekšējo literatūras analīzi, raksturo atsvešinātību, anomiju un sociālo fragmentētïbu (Seeman, 1959; Roberts, 1987; Srole, 1956; Dean, 1961; Teevan, 1975 u.c.). Sākotnējie jautājumi sīki aprakstīti pielikumā. Sākotnējais datu kopums ietvēra 1000 interviju, taču trūkstošu atbilžu dēḷ no analīzes tika izslēgti vairāki novērojumi. Galiggais modelis ir balstīts uz 672 respondentiem.

Vispiemērotākā metode sarežğìtu modelu un sakarību izpētei ir strukturālo vienādojumu modelēšana (SEM). SEM mainīgie var savstarpēji ietekmēt cits citu vai nu tieši, vai arī netieši, caur citiem mainigajiem. SEM uzmanības centrā nav tik daudz ìpašas attiecības starp mainigajiem, kā pārbaude, vai kopējais attiecību tìkls pietiekami labi apraksta datus (Fox, 2002).
Modelis sastāv no 1) mērỉjumu dalas, kas apvieno eksogēnus (tieši nomērìtus) mainīgos latentos endogēnos mainigajos, un 2) strukturālā modeḷa, kas sasaista endogēnos mainīgos ar eksogēnajiem mainīgajiem, kā ar savā starpā. Saistības vai saistību trūkums starp mainịgajiem (modela ierobežojumi) tika specificētas saskanā ar teoriju, kā aprakstîts ievadā. Modelis ietver arī endogēno un eksogēno mainīgo mērỉjumu kḷūdas; tas ḷauj noteik kovariāciju starp mērījumu kḷūdām $\varepsilon 19$ un $\varepsilon 20, \varepsilon 20$ un ع21, $\varepsilon 19$ un $\varepsilon 11$ (ṇemot vērā hipotētisko saikni starp anomijas un atsvešināšanās faktoriem), korelācijas starp atsvešinātību, normu trūkumu, sociālo atstumtību un politisko atsvešināšanos, kā arī vairākas kovariācijas starp eksogēno mainīgo kḷūdām (šeit nav attēlotas, lai nesarežg̀itu modeli). Modelis ir rekursìvs, jo tam nav atgriezeniskās saites. Modelis novērtēts pēc ADF (asimptotiskas, no sadalījuma brivas) metodes (sk. Fox, 2002), un tas tika aprēḳināts, izmantojot SPSS Amos 13.0.

Rezultāti

Sākotnējā modeḷa atbilstības rādītāji (šeit nav parādīti, pamatojas uz pielikuma IM1 tabulā aprakstīto struktūru) nebija apmierinoši, tāpēc modelis tika pārspecificēts, likvidējot saites, kas būtiski neatšķiras no «o» pat pie $90 \%(p>0,1)$ ticamības līmena un ko ierosināja AMOs modifikācijas indeksi modela uzlabošanai, vienlaikus tas arī atbilst teorijai. Piemēram, modela atbilstība tika ievērojami uzlabota, no modeḷa likvidējot jautājumus «Kopumā esmu pārliecināts, ka es īstenošu savus plānus», «Mērkis attaisno līdzeklus», «Ir daži principi dzīvē, kas jāievēro neatkarīgi no apstākliem», «Ir apstākli, kad var neturēt doto vārdu» un «Ja jūs vienmēr nebūsiet uzmanīgi, citi cilvēki jūs izmantos», jo tie vāji korelēja ar citiem analīzē ietvertajiem jautājumiem.

Galīgais respecificētais modelis parādīts 1. attēlā. Hī kvadrāta statistika modelim joprojām nav ideāla (chi-square $=177$ ar 102 brīvibas pakāpēm (df)), tomēr RMSEA (aptuvenā sakṇu kvadrāta kḷūda), kas ir modeḷa atbilstības indikators attiecībā pret populācijas piesātināto modeli, parāda, ka modelis datiem atbilst labi (RMSEA =0,033). NFI (standarta atbilstības indekss) o,94 nozīmē, ka pārbaudītā modeḷa vispārējais atbilstības līmenis ir par 94\% labāks nekā neatkarīgais modelis (kur mainīgie tiek uzskatīti par savstarpēji nesaistītiem), pamatojoties uz datiem par izlasi. Salīdzinošais atbilstības indekss (CFI), kas novērtē risinājuma atbilstību salīdzinājumā ar ierobežotāku bāzes modeli, kurā visu indikatoru kovariācijas ir fiksētas uz nulli vai kur nav saistības starp mainịgajiem, mūsu gadijjumā ir o,96, kas norāda uz labu modela atbilstību, un līdzīgus secinājumus var izdarìt no Takera-Lūisa indeksa (TLI), kura vērtība ir 0,97.

Modela mērījumu dala lauj nodalīt vairākus latentos faktorus, kas ir nedaudz atškirīgi, salīdzinot ar tiem, kuri minēti Rietumu literatūrā. 
1. «Normu trūkums» - likumu neievērošana. Šo dimensiju veido trīs pazimes - «Ir pieḷaujami apiet likumu ar lïkumu», «Ir pieṇemami neievērot likumu, ja likums ir pretrunā ar to, ko jūs uzskatāt par pareizu» un «Ir pieņemami nemaksāt nodokḷus»to svars dimensijas veidošanā ir līdzịgs. Normu trūkums ir dimensija, kas vistiešāk literatūrā saistīta ar anomiju (piem., MacIver, 1950). Kronbaha alfa vērtība šai dimensijai ir o,65, kas apliecina, ka skalas iekšējā validitāte ir diezgan laba.

2. «Kultūras atsvešinātība, izolētība»-raksturo indivìda atšḳeltību no sabiedrības normām un vispārēju kognitīvās integrācijas trūkumu sabiedrībā. Dimensiju veido trīs pazìmes: «Mani viedokḷi bieži atškiiras no manu ğimenes locekḷu viedokḷiem»; «Apkārt ir tik daudz viedokḷu, ka grūti pateikt, kur ir patiesība» un mazākā mērā «Man ir maz kopīga ar citiem cilvēkiem Latvijā». Tomēr šīs pazimes ir vâji korelētas, tādēl Kronbaha alfa lìmenis ir diezgan zems $(0,43)$.

3. "Atsvešinātiba no ğimenes, pienākumiem» - veidota no divām pazīmēm «Ir situācijas, kad ir attaisnojama neuzticība dzīvesbiedram» un «Ir situācijas, kad ir attaisnojami nerūpēties par saviem bērniem». Lai gan literatūrā šāds specifisks faktors nav minēts, var viegli iztēloties, ka tā ir vēl viena atsvešinātības pazime. Šìs pazimes arī nav ḷoti cieši saistītas $(0,3)$, tādējādi Kronbaha alfa ir 0,47

4. «Atsvešinātiba no sevis» - apraksta vispārēju uztveribezvērtību, jēgas un kontroles trūkumu pār savu dzivi. To veido piecas pazìmes: «Es bieži vēlos, kaut es būtu kāds cits», «Man ir maz kontroles pār to, kas ar mani notiek», «Dažkārt man liekas, ka esmu nekam nederīgs/-a» un nedaudz mazāk - «Mana dzìve - tā, kā es to dzìvoju -ir bezjēdzīga». Tas ir saistìts arī ar uzskatu, ka «Politiķus neinteresē tādi cilvēki kā es». Interesanti, ka atsvešinātība no sevis šajā gadijjumā ir apvienojusies ar bezspēcības sajūtu. Kronbaha alfa skalai «Atsvešinātỉba no sevis» ir samērā laba-o,6 vai o,66, ja tiek izslēgta pēdējā pazime.

5. «Ilgtermiṇa mērķu, vizijas trūkums» - atsevišḳs faktors, kas arī veicina anomiju. Tas apraksta vispārēju dzīves vadlīniju un rītdienas plānošanas trūkumu. To labāk izprast palīdz Makaivera (MacIver, 1950) arguments. Viņš uzskata, ka anomija ir «tādu vērtỉbu trūkums, kas varētu dot mērḳi vai dzives virzību, iekšèjo un socializēto vērtỉbu zaudēšana, bezcerīgi dezorientēto nedrošiba».

6. «Sociālā atstumtība» - šo faktoru veido uzticēšanās (jeb uzticēšanās trūkums) cilvēkiem un tas, ka respondentam ir maz kopīga ar citiem cilvēkiem. Tā kā korelācija starp pazīmēm ir diezgan vāja, Kronbaha alfa vērtība ir tikai o,4.

7. «Politiskā atsvešinātība»-rāda, cik liela ir uzticēšanās

parlamentam un valdībai, mazākā mērā - pārliecība, ka «politikus neinteresē tādi cilvēki kā es». Kronbaha alfa šajā gadījumā ir loti laba $(0,76)$, kas norāda, ka pazimes veido saskaṇotu skalu.

Tika specificēti divi atsevišḳi modeḷi-vienā no tiem normu trūkums (anomija) tika specificēts kā viena no atsvešinātības dimensijām (paralēli ar, piemēram, atsvešinātību no sevis), bet otrā tas veidoja atsevišķu faktoru, kas bija saistīts ar citiem (lìdztekus atsvešinātībai, sociālajai atstumtībai un politiskajai atsvešinātībai). Pirmajā gadijumā modeḷa hī kvadrāts (CMIN) bija 195 ar 104 brīvïbas pakāpēm (df's), NFI - o,93, TLI-0,95, CFI - o,96 un RMSEA - 0,036. Otrajā gadỉjumā hỉ kvadrāts (CMIN) bija 177 ar 102 df's, NFI 0,94, TLI - o,96, CFI - o,97 Un RMSEA-0,033.

Lai salīdzinātu, vai viens no modeliem ir ievērojami labāks par otru, tika izmantots hỉ kvadrāta noviržu tests (chi-square deviation test). Atšķiiība starp hỉ kvadrāta vērtībām (18) ar atškirību brīvības pakāpēs df's (2) ir statistiski nozìmīga pie o,oo1 nozìmỉbas līmeṇa, tādēl tika noraidìta hipotēze par anomiju kā vienu no atsvešinātỉbas dimensijām $\left(\mathrm{H}_{2}\right)$. Balstoties uz šiem rezultātiem, modelī, kas izmantots turpmākajā analīzē, tiek pienemts, ka normu trūkums (anomija) ir jēdziens, kas ir atškirīgss no atsvešinātības (1. attēls).

Dimensijas, kas visvairāk veido atsvešinātību, ir «Atsvešinātība no sevis» un «Atsvešinātība no ǵimenes, atbildỉbas», jo īpaši pazìmes «Ir situàcijas, kad var attaisnot neuzticību dzivesbiedram» (kopējais standartizētais efekts 0,75$)$ un «Es bieži vēlos, kaut es būtu kāds cits» (o,68). Atsevišķi viens no spēcīgākajiem kopējiem efektiem ir pazìmei «Mūsdienās cilvēkam ir jādzīvo šodienai» $(0,67)$. Kopumā dati vismaz dalẹeji atbalsta hipotēzi (H1), ka bezspēcība un atsvešinātîba no sevis ir galvenie atsvešinātības elementi.

Kaut arī normu trūkums (anomija) tika nodalìts kā no atsvešinātības atškirīgs jēdziens, šie divi jēdzieni ir diezgan cieši saistīti (kor. koef. $=0,47$ )

Apstiprinājās arī hipotēze par politisko atsvešinātību un sociālo atstumtību kā atseviškiiem aspektiem, kas saistīti ar anomiju (H3). Anomija (normu trūkums) ir īpaši cieši saistìta ar sociālo atstumtību, kas nav pārsteigums. Lìdzīgi kā citi pētījumi, arī šis atklāj korelāciju starp sociālo atstumtỉbu un politisko atsvešinātỉbu. No otras puses, atsvešinātība nav tik cieš saistìta ar sociālo atstumtību un politisko atsvešināšanos. Pirmajā gadijjumā kovariance ir nozīmīga tikai pie o,1 līmeṇa, bet otrajā - pie o,o1 līmenna

Aplūkojot anomijas un atsvešinātības lïmeni Latvijā, to var raksturot kā mērenu (1.tabula). Plaši izplatìta ir politiskā atsvešinātība $(60,8)$, kā arī sociālā atstumtỉba $(36,0)$ un normu trūkums/anomija $(0,37)$. 
1. attēls. SE M modelis (standartizēti koeficienti)
E1 $\rightarrow$ Ir pienemami neievērot
E1 likumu...
E2 $\rightarrow$ Ir pienemami izvairitie
E3 $\rightarrow \begin{aligned} & \text { Ir pielaujami apiet } \\ & \text { likumu... }\end{aligned}$
E4 $\rightarrow$ Lielākajai daḷai cilvēku
E5 $\rightarrow \begin{aligned} & \text { Man apkārt ir cilvēki, uz } \\ & \text { kuriem varu palauties }\end{aligned}$
E6 $\rightarrow \begin{aligned} & \text { Man ir maz kopiga } \\ & \text { ar citiem... }\end{aligned}$
E7 $\rightarrow$ Tik daudz viedoklu - grū
E8 $\rightarrow \begin{aligned} & \text { Manas domas atškiras } \\ & \text { no gimenes... }\end{aligned}$
E9 $\rightarrow$ Ir situācijas, kad attaisno-
E10 $\rightarrow \begin{aligned} & \text {...pielaujamiami nerūpēties } \\ & \text { par saviem bērniem }\end{aligned}$
E11 $\rightarrow$ Mūsdienās cilvēkam ir
E11 $\rightarrow$ jādzivo šodienai
E12 $\rightarrow \begin{aligned} & \text { Es bieži vēlos, kaut es } \\ & \text { būtu kāds cits... }\end{aligned}$
E13 $\rightarrow \begin{aligned} & \text { Dažkārt man liekas, ka } \\ & \text { esmu nekam nederigss }\end{aligned}$
E14 $\rightarrow \begin{gathered}\text { Mana dzive... } \\ \text { ir bezjēdziga }\end{gathered}$
E15 $\rightarrow \begin{aligned} & \text { Man ir maz kontroles pār } \\ & \text { to, kas ar mani notiek }\end{aligned}$
E16 $\rightarrow$ Politiǩus neinteresē
E16 $\rightarrow$ tādi cilvēki kā es
E17 $\rightarrow \begin{aligned} & \text { Uzticēšanā } \\ & \text { Saeimai }\end{aligned}$
E18 $\rightarrow \underset{\substack{\text { Uzticēšanās } \\ \text { valdibai }}}{\text { and }}$

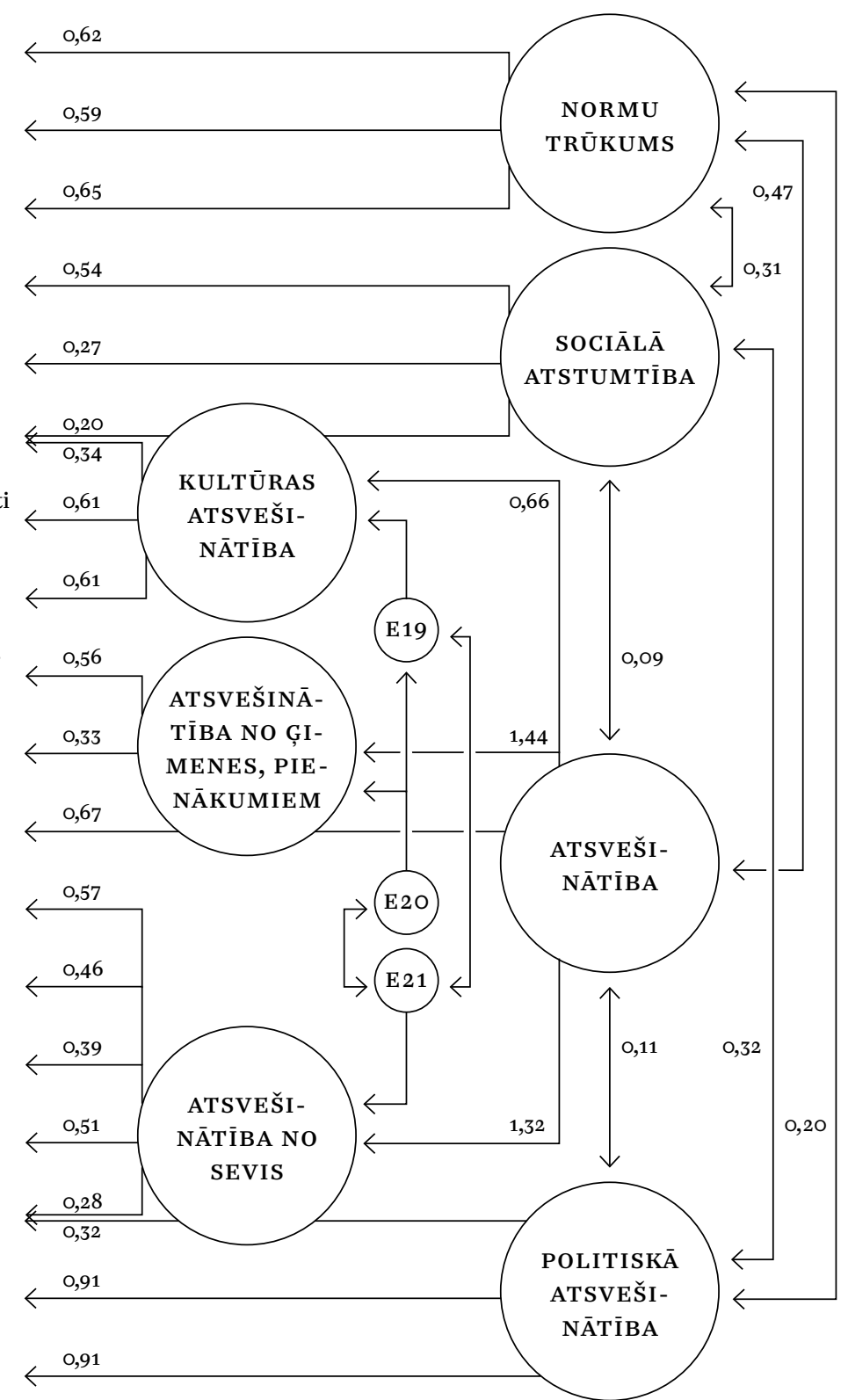

SUSTINNo aptaujas dati, autores aprēḳini.
1. tabula. Anomija un atsvešinātība Latvijā (skalā no o līdz 100)

\begin{tabular}{|c|c|c|}
\hline Indikators & Vērtíba & \\
\hline Ilgermiņa mērḳu trūkums & |||||||||||||||||||||||||||||||||||||||||| $\mid$ & $56,8 \%$ \\
\hline Kultūras atsvešinātība & |||||||||||||||||||||||||||||||||||||||| & $51,2 \%$ \\
\hline Atsvešinātība no sevis & |||||||||||||||||||||| & $28,5 \%$ \\
\hline $\begin{array}{l}\text { Atsvešinātība no ğimenes, } \\
\text { pienākumiem }\end{array}$ & |||||||||||||||| $\mid$ & $22,8 \%$ \\
\hline Atsvešinātība & |||||||||||||||||||||||| $\mid$ & $34,5 \%$ \\
\hline Normu trūkums & |||||||||||||||||||||||||||| & $37,3 \%$ \\
\hline Politiskā atsvešinātība & |||||||||||||||||||||||||||||||||||||||||||| $\mid$ & $60,8 \%$ \\
\hline Sociālā atstumtība & ||||||||||||||||||||||||||| & $36,0 \%$ \\
\hline
\end{tabular}

Piezīme. Attieksmju rāditāiji ir pārrēẹināti skalā no o līdz 10o, ṇemot vērā pazimes relativo svaru, veidojot faktoru (faktoru slodzes).

No visām atsvešinātības dimensijām ilgtermiṇa mērḳu/vīzijas trūkums un kultūras atsvešinātỉba ir lielākās problēmas Latvijā. Iespējams, ka dzive šodienai vai mērḳtiecības, tālāku mērḳu trūkums ir saistîts ar piedzìvotajiem pārejas procesiem. Cilvēki neiemācijās domāt ilgtermiṇā, uzskatot, ka situācija jebkurā brīiī var strauji mainīties. Arī kultūras atsvešinātība ir raksturīga pārejas sabiedrībām, un tā norāda uz vērtîbu krīzi, jo cilvēki pāriet no viena pieņemama uzvedības vai vēlamo mērķu kopuma uz citu. Atsvešinātība no sevis un ǵimenes pienākumiem - visietekmīgākās atsvešinātības dimensijas - ir mazāk raksturīgas Latvijas sabiedrībai.

Atsvešinātība ir īpaši raksturīga sabiedrības zemākajiem slāniem (Sig.<0,05). Normu trūkums un sociālā atstumtība visbiežāk izplatîta jauniešu vidū, norādot uz jauniešu sociālās atstumtības problēmu Latvijā. Interesanti, ka jaunieši jūtas sociāli atsvešināti, savukārt gados vecāki cilvēki jūtas politiski atsvešināti. Politiskā atsvešināšanās ir daudz izplatītāka nabadzīgāko sabiedrības slāṇu vidū, tātad viṇi jūtas atstumti no politiskā procesa (Sig.< < ,001). 
Jaunāki cilvēki līdz zo gadu vecumam, kā arī tie, kas pārstāv sabiedrības zemākās ienākumu grupas, ir tie, kuri visbiežāk dzīvo šodienai (Sig.<0,o1). Tas norāda, ka «mūsdienās dzīvojošs» nav tikai priekšrocība vai izvēle, bet tas var būt arì sliktu finansiālo apstākḷu rezultāts. Arī atsvešinātỉba no ǵimenes, pienākumiem ir visplašāk izplatìta nabadzīgāko iedzīvotāju vidū, tomēr interesanti, ka tā palielinās arī starp turīgākajām sabiedrỉbas grupām. Atsvešinātība no sevis Latvijā diemžēl pieaug ar vecumu, jo vecāki cilvēki jūtas arvien nevajadzịgāki (Sig.< <,05). Šì sajūta ir saistìta ar ienākumiem un samazinās līdz ar pieaugošiem ienākumiem (Sig.< <,oo1). Tas parāda, ka pašvērtējuma sajūta ir vismaz nedaudz ir saistīta ar ienākumiem. Kultūras atsvešinātība nedaudz vairāk piemit krievu tautības cilvēkiem, taču atškirīibas nav statistiski nozimīgas $(\mathrm{Sig}=0,07)$.

\section{Vērtības}

Inglhārta materiālisma-postmateriālisma skalu (Inglehart \& Flanagan, 1987; Inglehart, 1999), kā arī Šaloma Švarca (Schwartz, 2012) vērtību skalu.

Analīze liecina, ka 12,3\% Latvijas iedzīvotāju uzskatāmi par izteiktiem materiālistiem (pielikumā atspoguḷotajos jautājumos V6o-V64 visos gadījumos par prioritāriem uzskatīti materiālie mērkii) vai materiālistiem. Loti daudzi (35,5\%) ir nedaudz materiālisti, bet 37,7\% nav pieskaitāmi ne pie vienas, ne otras grupas. Salīdzinoši mazāka dą̣a sabiedrỉbas uzskatāma par nedaudz postmateriālistiem (12,9\%) vai postmateriālistiem (1,6\%) (1. tabula). Šis rezultāts saskan ar Inglhārta atzinām par pārmainu sabiedrībā dominējošām materiālisma vērtỉbām, kamēr turīgākas, attīstìtākas sabiedrības biežāk dod priekšroku postmateriālisma vērtībām (Inglehart, 2006).

Analīze liecina, ka materiālisms ievērojami pieaug ar vecumu (īpaši vecuma grupā pēc 45 gadiem), tomēr arī jauniešu grupā biežāk sastopami materiālisti nekā postmateriālisti. Švarca vērtību analīze atklāj, ka Latvijas sabiedrībā dominējošās vērtības ir t.s. sevis pārvarēšanas vērtības pretstatā pašpiepildijjuma vērtībām. Latvijas iedzivotāiem vistuvākās ir universālisma vērtības (sociālais taisnīgums, miers pasaulē, gudrība u. c.), labvēlība (godīgums, piedošana u.c.), kā arī pašrealizācija (radošums, pašciena, neatkarība). Loti reti iedzivotāji tiecas pēc varas, sasniegumiem, stimulācijas (aizraujoša dzīve u.c.) un hēdoniskas dzìves. Tas liecina par zināmu atvērtības pārmaiṇām trūkumu, kas raksturīgs mazāk turīgām sabiedrībām. Interesanti, ka vienlaikus ar tieksmi pēc pašrealizācijas ḷoti augsta nozīme Latvijas sabiedrïbā tiek pieškiirta drošǐbai (valsts drošỉbai, piederības sajūtai u.tml.). Šīs vērtības tradicionāli tiek vērtētas kā pretnostatītas. Tāpat anomijas kontekstā būtiski, ka konformitāte (paklausība, pieklājība u.c.) Latvijas sabiedrībā netiek augstu vērtēta, kas apliecina tendenci mazāk paklauties sabiedrỉbas normām. 


\section{2. attēls. Materiālisma-postmateriālisma vērtības Latvijas sabiedrībā}

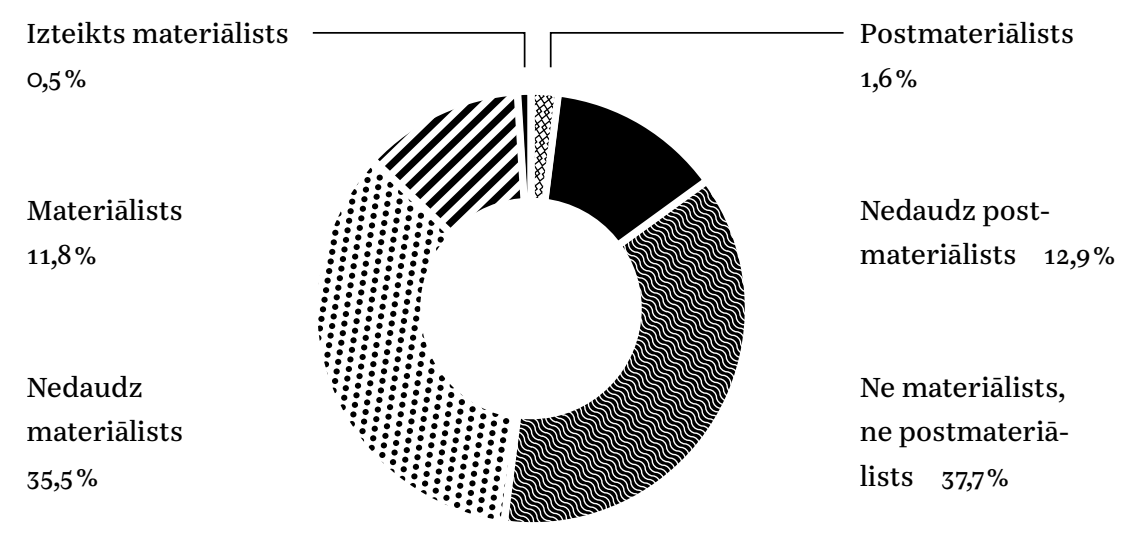

3. attēls. Latvijas sabiedrības vērtības

PAŠPIEPILDĪJUMS

Vara (sociāāā atziniba, bagātiba u.c.)

Sasniegumi (ambicijas, spējas, panākumi u.c.)

Hēdonisms (dzives baudišana u.c.)

$$
\text { Drošǐba (valsts drošỉba, }
$$
piederibas sajūt
tirigums u.c.)

SAGLABĀŠANA

Konformitāte (paklausiba,

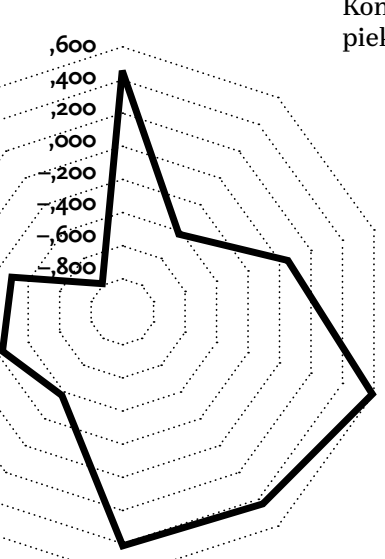
nỉba, esošās dzives pieṇemšana u.c.)

Labvēliba (godigums, lojalitāte, piedošana u.c.)

Stimulācija (aizraujoša dzive u.c.)

ATVĒ RTīBa PĀrmaināM
Pašrealizācija (radošums, pašciena (radošums, pašcien, taisnigums, miers pasaulê gudriba u.c.)

SEVIS PĀRVARĒŠANA
Universālisms (sociālais
Veiktā analīze lāva nodalīt nedaudz atškirīgas anomijas dimensijas un to saturu salīdzinājumā ar Rietumu literatūrā analizētajām. Tomēr kopumā rezultāti apstiprina Robertsa (Roberts, 1987) pieṇēmumu, ka bezspēcība un atsvešinātība no sevis ir izteiktākās anomijas dimensijas, kam seko normu un skaidras pārliecības trūkums.

Analizze liecina, ka anomiju nevar uzskatît par atsvešinātỉbas izpausm vai vēl vienu tās dimensiju: tie ir divi atsevišḳi, lai gan cieši saistiti koncepti. Arī politisko atsvešinātỉbu un sociālo atstumtìbu, lai gan tie ir saistīti ar anomiju, nevar uzskatīt par tiešām anomijas izpausmēm.

Lūkojoties no anomijas perspektivas, Latvijas sabiedrïbas visproblemātiskākie aspekti ir bezmērkība (dzīve šodienai) un kultūras atsvešinātība, ko zināmā mērā var saistīt ar pārejas procesu no vienas politiskās un ekonomiskās sistēmas uz citu. Šie rezultāti norāda uz zināmu vērtību krīzi, kad cilvēki nav pārliecināti, ko vini cenšas panākt ilgtermiṇā; viniem trūkst skaidru dzīves vadlīniju, un vini jūtas kulturāli atsvešināti no góimenes un sabiedrības. Latvijā diezgan izplatīts ir arī normu trūkums, it îpaši jauniešu vidū. Lai gan jaunieši jūtas sociāli izstumti un tiecas dzīvot šodienai, vecāki cilvēki biežāk jūtas atsvešināti no sevis un no politiskā procesa.

Dzive šodienai un atsvešinātība no ǵimenes un pienākumiem vismaz daḷēji varētu tikt izskaidrota ar iedzīvotāju zemajiem ienākumiem: šāda attieksme ir izplatītāka nabadzịgāko sabiedrības slānu vidū. Nabadzīgākie iedzivvotāji arī biežāk mēdz justies atsvešināti no sevis un loti skaidri izjūt izolāciju no politiskā procesa. Statistikas dati liecina, ka Latvijā vērojams viens no visaugstākajiem ienākumu nevienlīdzības līmeniem Eiropā, novedot pie negativvas pašuztveres un politiskā procesa uztveres sabiedrības zemākajos slāṇos. Kopumā ši ir visvairāk atsvešinātā grupa Latvijā.

Anomija zināmā mērā izpaužas arì sabiedrỉbas vērtībās. Latvijas iedzīvotāji vienlaikus tiecas pēc pašrealizācijas un drošỉbas - vērtībām, kas parasti tiek uzskatītas par pretējām. Turklāt salīdzinoši zemu tiek vērtēta konformitāte (paklausība, pieklājība u.tml.), radot pamatu salīdzinoši mazākai paklāvībai sabiedrības normām. Vēlme dzīvot šodienai un ilgtermina mērḳu trūkums sasaucas ar pašpiepildỉjuma vērtību (vara, sasniegumi) nelielo nozìmi Latvijas sabiedrībā, tā vietā dominē sevis pārvarēšanas vērtības (labvēlī ba, universālisms).

Turpmākajos pētījumos nevajadzētu izvairīties no sociālās atstumtības un politiskās atsvešinātỉbas mērī̌šanas, un tajos jāietver arī atsvešinātība no darba, kas šajā pētỉjumā netika aplūkota. Nepieciešami pētījumi, kas aptvertu vairākas valstis un kultūras, jo veiktā analīze skaidri parāda, ka atsvešināšanās un anomijas struktūra dažādās valstīs var atškirties atkarībā no vēsturiskā, kultūras un ekonomiskā konteksta. 
Pielikums. IM1. Tagad es nolasišu vairākus apgalvojumus un lūgšu novērtēt, cik lielā mērā Jūs piekrītat vai nepiekrītat šiem apgalvojumiem
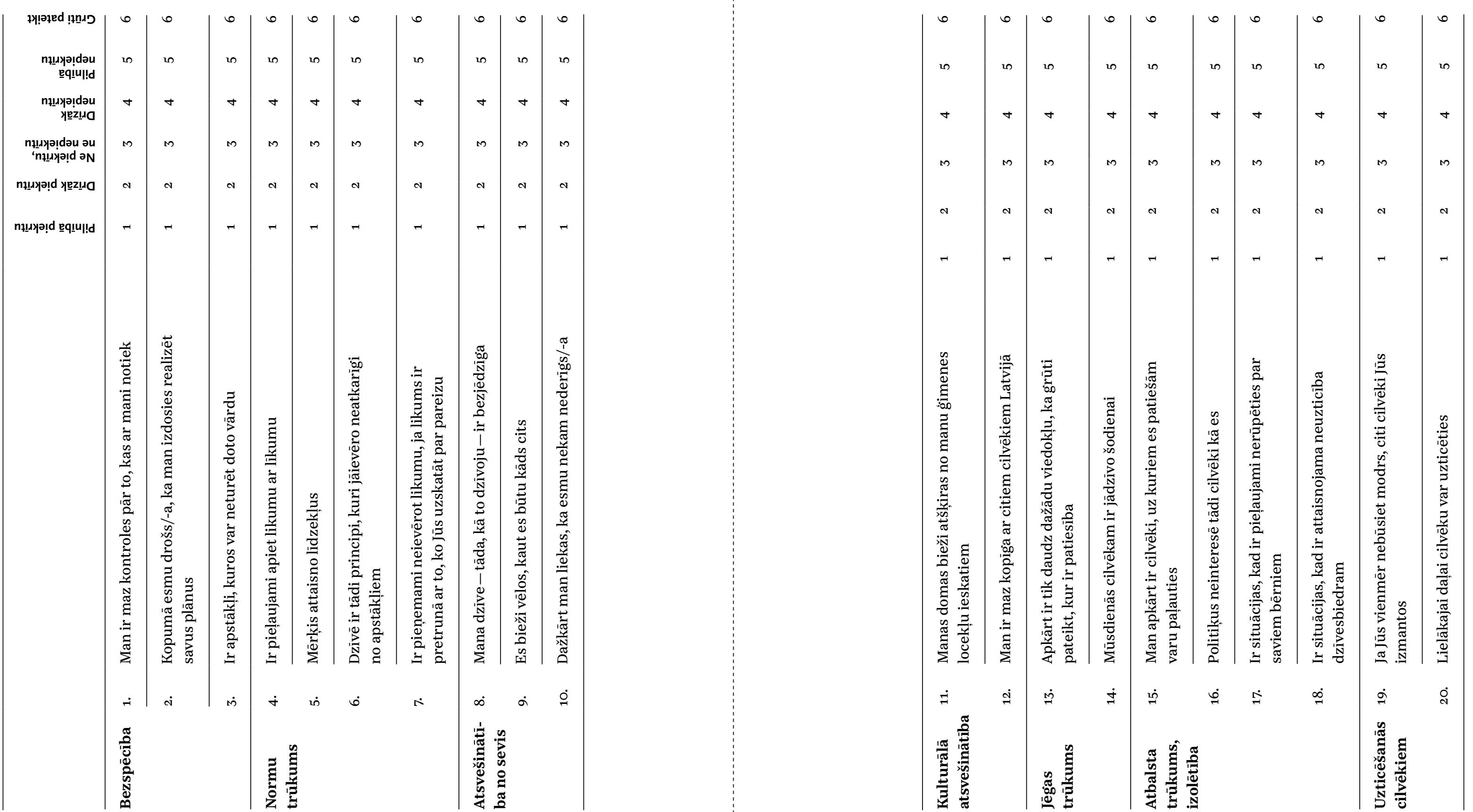


\section{Q2. Cik lielā mērā Jūs uzticaties...}

Valdībai

Parlamentam

Partijām

60. Cilvēki dažkārt mēdz runāt par to, kādiem būtu jābūt šīs valsts mērkiem tuvākajiem desmit gadiem. Šajā kartītē ir minēti daži no mērḳiem, kurus dažādi cilvēki uzskatītu par prioritāriem. Kuru no turpmāk minētajiem mērkiem Jūs personīgi uzskatāt par vissvarīgāko?

(atzīmējiet pie «Pirmā izvēle»)

V61. Un kuru par otru svarīgāko? (atzīmējiet pie «Otrā izvēle»)

\begin{tabular}{lrr}
\hline & V6o & V61 \\
\hline Panākt ievērojamu ekonomikas izaugsmi & 1 & 1 \\
\hline Nodrošināt spēcīgu valsts aizsardzību & 2 & 2 \\
\hline $\begin{array}{l}\text { Panākt, ka cilvēkiem ir vairāk teikšanas tajā, kā notiek } \\
\text { lietas viṇu darbā un kopienā }\end{array}$ & 3 & 3 \\
\hline Censties padarìt skaistākas mūsu pilsētas un laukus & & 4 \\
\hline
\end{tabular}

V62. Ja Jums būtu jāizvēlas, kura no šìm lietām, Jūsuprāt, ir vissvarīgākā? (atzīmējiet pie «Pirmā izvēle»)

V63. Un kura ir otra svarīgākā? (atzīmējiet pie «Otrā izvēle»)

\begin{tabular}{lrr}
\hline Uzturēt kārtỉbu valstī & 1 & 1 \\
\hline Palielināt cilvēku ietekmi uz valdības lēmumu pieṇemšanu & 2 & 2 \\
\hline Cīnīties pret cenu celšanos & 3 & 3 \\
\hline Aizsargāt vārda brīvibu & 4 & 4 \\
\hline
\end{tabular}

V64. Šeit ir vēl viens saraksts. Kas no šĩ, Jūsuprāt, ir vissvarīgākais? (atzīmējiet pie «Pirmā izvēle»)

V65. Un kas, Jūsuprāt, ir otrs svarīgākais? (atzīmējiet pie «Otrā izvēle»)

V64 V65

\begin{tabular}{lcc} 
& V64 & V65 \\
\hline Stabila ekonomika & 1 & 1 \\
\hline $\begin{array}{l}\text { Virzība uz cilvēcīgāku un mazāk bezpersonisku sabiedrību } \\
\text { Virzība uz tādu sabiedrību, kurā idejas tiek vērtētas }\end{array}$ & 2 \\
\hline $\begin{array}{l}\text { augstāk nekā nauda } \\
\text { Cinna pret noziedzìbu }\end{array}$ & 3 & \\
\hline
\end{tabular}




\section{Ar balsi vien? Mediju patērina, vērtīborientāciju un valdības darbības vērtējuma ietekme uz Latvijas iedzivotāju attieksmēm pret valsts drošibu}

Jānis Ikstens
21. gadsimta sākumā ir atjaunojusies interese par propagandu, tās lomu un iespējām mazināt tās ietekmi. Transatlantiskajā telpā, t. sk. Eiropā, šo interesi veicina Krievijas darbibas, cenšoties paplašināt savu globālo ietekmi un šì mērḳa sasniegšanai izmantojot gan militārus, gan nemilitārus līdzekḷus. Nemilitāro līdzekḷu pievilcību ietekmē to izmantošanas salïdzinoši mazās izmaksas un arī grūtības, ar kurām jāsastopas, cinoties pret Krievijas informatīvajiem pasākumiem, t. sk. propagandu demokrātiska politiskā režìma ietvaros.

Pastiprināta uzmanība Krievijas informativijiem pasākumiem sākta pievērst pēc kara sākuma Ukrainā 2014. gadā. Šis kampaṇas ietvaros Krievija izmantoja gan brunotu spēku, gan arī plašu dezinformācijas kampanu, raisot jautājumus par līdzīgu panēmienu izmantošanu citās bijušās PSRS teritorijās. Tika uzskatīts, ka militārās pretestības vājināšanai un NATo dalībvalstu sabiedrības spiediena mazināšanai Krievija varētu izmantot savu propagandu, atainojot agresijas mērḳvalstis nepievilcīgā veidā.

Latvija tika uzskatīta par vienu no Krievijas nemilitārajiem apdraudējumiem visvairāk pakḷautajām valstīm. To noteica gan plaša austrumslāvu segmenta klātbūtne sabiedrībā un gadu desmitiem ilgie Krievijas centieni îstenot šì segmenta interešu aizstāvības politiku atbilstoši savai izpratnei par šìm interesēm, gan arì labās krievu valodas zināšanas un mediju patēriṇa ieradumi Latvijas sabiedrībā, kas dabiski palielināja tās atvērtību Krievijas propagandai.

Kaut gan daudzos pētījumos ir identificēti noteikti vēstījumi, kurus Krievija aktīvi komunicē savā propagandā pret Latviju, nav skaidrs, cik plašu rezonansi tie ir guvuši Latvijas sabiedrībā. Vēl neskaidrāks ir tas, kādi faktori sekmē (vai kavē) uzṇēmību pret Krievijas propagandas vēstijumiem. Tāpēc šajā nodaḷā tiks analizēts, cik lielā mērā krievvalodīgo plašsazinas lỉdzekḷu patērinš ietekmē Krievijas propagandas vēstijumu izplatību. Turklāt šajā analīzē iekḷauti arī tādi neatkarīgie mainigie kā indivìda vērtỉborientācijas, sociāll demogrāfiskie parametri un uzskati par valdības darbu. Iepriekš veiktie pētījumi vedina uzskatit, ka katrai no šo neatkarīgo mainīgo grupām ir noteikta ietekme uz individu politiskajiem uzskatiem. Tiek sagaidits, ka plašsaziñas līdzekḷu patēriṇa ieradumi būs tie, kas visvairāk ietekmēs uzṇēmību pre Krievijas propagandas vēstijumos iekodētajām attieksmēm. tieksmēm ir ilgstoši atradušās dažādu sociālo zinātṇu uzmanỉbas lokā (Goffman, 1974; Kahnemann, 1979; Tversky \& Kahnemann, 1981; Iyengar \& Kinder, 2010). Pakāpeniski ir izkristalizējušās trīs nozīmịgākās mediju funkcijas dienaskārtības definēšana (agenda-setting), rāmēšana (framing) un ìstermina 
ietekmēšana (priming). Šĩ pētijuma kontekstā nozīmīgākā ir tieši îstermina ietekmēšana, kas tiek definēta kā to atskaites punktu pārmaiṇas, kurus cilvēki izmanto, lai veidotu politiskus spriedumus un novērtējumus (Iyengar \& Kinder, 2010). Citiem vārdiem sakot, istermiṇa ietekmēšana ir novērojama tad, kad mediji spēj pārliecināt savu auditoriju, ka valdỉbas darbïbas vērtējumam ir jāizmanto konkrēti jautājumi vai kritēriji, piemēram, attieksme pret mazākumtautībām. Viena no teorijām psiholog̣ijā postulē, ka cilvēki veido savus uzskatus, balstoties uz apsvērumiem, kas ir visbiežāk sastopami uzskatu formulēšanas brīdī (Hastie \& Park, 1986). Tāpēc var pieṇemt, ka cilvēku uzskatu izmaiņas būs saistitas ar mediju aktivitāti un saturu attiecīgajā laika posmā. Šis novērojums savukārt vedina dienaskārtības definēšanu ciešāk saistīt (McCombs \& Shaw, 1972) ar ìstermina ietekmēšanu.

İstermiṇa ietekmēšanas loma auditorijas uzskatu veidošanā par ārvalstīm ir dokumentēta dažādos kontekstos (Allen et al., 1994; Willnat et al., 2000; Brewer et al., 2003; Clemons et al., 2016). Krievijas pieaugošā aktivitāte šīs valsts maigās varas stiprināšanas jomā (Simons, 2015; Sergunin \& Karabeshkin, 2015) ir sekmējusi akadēmisko interesi par Krievijas plašsaziņas līdzekḷu ietekmïgumu. Kaut gan Krievija ir centusies piemērot savām vajadzībām ASV un citu attīstîto valstu maigās varas veidošanas stratẹgijijas, virkne empīisko pētijumu par Baltijas valstīm un Ukrainu vedina domāt, ka Krievijas mediju ietekme ir vērtēta pārāk augstu (Hudson, 2015; Nielsen \& Paabo, 2015).

Lìdztekus mediju lomai pētnieki ir uzsvēruši arī citus faktorus, kas ietekmē indivìdu uzskatus, t. sk. sociālekonomiskais statuss, demogrāfiskās pazimes, valdības darba novērtējums un indivìdu vērtīborientācijas.

Sociālekonomiskā statusa saikne ar individa attieksmēm ir plaši pētīta, t. s. Kolumbijas skolai liekot svarīgus pamatus šai jomā ar pētijumiem par sociāli demogrāfisko faktoru ietekmi uz pilsoṇu izvēli vēlēšanās (Lazarsfeld et al., 1944). Šì skola arī veica pirmos pētijumus par plašsazinas lìdzeklu ietekmi uz vēlētājiem, konstatējot, ka tieši sociālie un demogrāfiskie mainigie ir nozīmiggāki vēlētājus ietekmējoši faktori nekā mediji. Tiesa, gadsimtu mijā arvien vairāk tiek atzìta mediju ietekme uz politiskajām attieksmēm un uzvedību (Pharr \& Putnam, 200o), pēdējos gados akcentējot sociālo mediju lomu - tie rada t.s. filtru burbuḷus, ko vieno salīdzinoši homogēna informācija, kas tajos cirkulē (Pariser, 2011; Flaxman et al., 2016). Tomēr sociālekonomiskā statusa ietekme joprojām tiek uzskatīta par vērā nemamu. Atbilstoši modernizācijas teorijai individi ar augstākiem ienākumiem biežāk pauž atbalstu demokrātijai (Lipset, 1959; Andersen, 2012). Arī populisma uzplaukums 21. gadsimta sākumā tiek saistìts ar ienākumiem un ekonomisko situāciju valstī (Rico \& Anduiza, 2016). Formālās izglìtỉbas līmenis tiek saistîts ar atbalstu noteiktām ideoloğiskām nostājām (Jacoby, 1991; Knutsen, 2012).

Sociālekonomiskais statuss var būt saistìts ar to, kā individs vērtē politiskos procesus un publiskās pārvaldes rezultātus. Taču šis vērtējums tiek izcelts kā atsevišks faktors, kas spēj ietekmēt virkni politisko uzskatu. Īpaši plaši tas tiek izmantots politiskā režima leğitimitātes pētijumos (Levi et al., 2009). Priekšstati par publiskās pārvaldes darbïbu tiek saistīti gan ar režīma leǵitimitātes apjomu (Gilley, 2006), gan arī ar indivïdu iesaistišanos vardarbìgā pretestỉbā politiskajam režìmam (Gurr, 1970).

Sociālajās zinātnēs vērtībām jau ilgstoši ir piedēvēta nozīmīga ietekme uz indivīda rīcību (Durkheim, 1897/1951; Weber, 1905). Tomēr vērtïbu konceptualizēšana un operacionalizēšana ir bijis ilgsstošu akadēmisko diskusiju objekts, un tāpēc ir izkristalizējušās divas biežāk izmantotās pieejas. Ronalds Inglhārts saskatiija postmateriālistisko vērtību izplatību sabiedrībā (Inglehart, 1977, 1990). Savukārt Šaloms Švarcs identificēja desmit vērtỉbu dimensijas, kuras, vinapapāt, ir raksturīgas dažādu kultūru pārstāvjiem un skaidro indivīda rīcību dažādās jomās, t. sk. politikā (Schwartz, 2012).

Lìdz šim politisko procesu analīzē biežāk izmantota tieši Inglhārta teorija, ar postmateriālismu skaidrojot gan atbalstu demokrātijai un politiskaja sāncensībai (Inglehart, 2003), gan politisko līdzdalību (Inglehart, 1979; Henn et al., 2017), gan atbalstu ekoloğismā sakṇotām politiskajām partijām (Rohrschneider, 1993). Lỉdztekus tam ir saskatāms, ka postmateriālisms ietekmē indivīdu attieksmi pret apkārtējās vides aizsardzību (Gelissen, 2007), indivīdu iesaistī̌anos uzṇēmējdarbībā (Uhlaner \& Thurik, 2007), taisnīguma un starppersonu uzticēšanās lìmeni (Warren, 1999).

Tomēr ari Švarca vērtību teorija ir pieaugoši izmantota politiskā procesa interpretācijai. Vērtības tiek cēloniski saistìtas ar noteiktu politisko vērtību esamību (Schwartz et al., 2014). Virkne pētijumu liecina, ka vēlētāji izvēlas balsot par tādām politiskajām partijām, kuru programmatiskās platformas vai tēls vedina uzskatīt, ka tās visvairāk atspoguḷo attiecigajam vēlētājam raksturiggākās vērtības (Caprara et al., 2006; Piurko et al., 2011). Noteiktas vērtību dimensijas palielina politisko lïdzdalību (Vecchione et al., 2015), kā arī ir saistītas ar indivīdu ārpolitiskajām orientācijām - indivīdi, kam raksturīgas tādas vērtības kā universālisms, dod priekšroku starptautiskai sadarbībai un kosmopolītiskai ārpolitikai, bet individi ar drošìbas un konformitātes vērtībām labprātāk atbalsta stingrās rokas ārpolitiku atbilstoši valsts militārajām spējām (Rathbun et al., 2016). Tieši šis pētijums nonāk vistuvāk šai nodaḷāâ aplūkotajai problemātikai.

\section{Metodologija}

Šì pētījuma empīriskajā pamatā ir Latvijas iedzivotāju aptauja, kas tika veikta 2015. gada vasarā. Izmantojot nejaušās stratificētās daudzpakāpju izlases veidošanas principu, tika iegūts viens tūkstotis pabeigtu interviju ar respondentiem visā Latvijas teritorijā, kuru vecums aptaujas veikšanas brīī bija 18-74 gadi. Lai nodrošinātu sasniegtās izlases precīzāku atbilstību Latvijas 
iedzīvotāju ğenerālkopai, iegūtie dati tika svērti, izmantojot informāciju par Latvijas iedzīvotāju dzimuma, vecuma un etnisko struktūru. Datu analīze tika veikta IBM SPSS Statistics programmatūras 22.0 versijā.

Pētijjumā analizētie Krievijas propagandas vēstijumi ir pārnemti no Austrumeiropas politikas pētijumu centra rakstu krājuma par Krievijas publisko diplomātiju (Kudors, 2014), pielāgojot tos iedzīvotāju aptaujas formātam. Lỉdztekus tam aptaujā tika iekḷauti arī jautājumi, kas atspoguḷo respondentu uzskatus par publiskās pārvaldes sistēmas darbības rezultātiem.

Lai mērītu respondentu vērtỉborientācijas, izmantots Šaloma Švarca radītais teorētiskais ietvars un tā operacionalizācija, kas tiek lietota Eiropas Sociālajā pētījumā (European Social Survey-ESS). Aptaujas jautājumu formulējumi latviešu valodā tika pārnemti no ESS instrumentārija.

Krievijas vēstijumu izplatība Latvijas sabiedrībā

Krievijas politiskais režims ir piedzivojis zināmu evolūciju kopš 20 . gadsimta nogales, un 21. gadsimta sākumā tas tiek dēvēts par autoritāru - Levickis un Vejs runā par sāncensīgo autoritārismu Krievijā (Levitsky \& Way, 2010); Freedom House veidotajā Brīvības indeksā 2017. gadā Krievija ir nodēvēta par nebrīvu valsti (Freedom House, 2017); The Economist Intelligence Unit veidotajā demokrātijas indeksā Krievijas rādītāji ir pastāvigi mazinājušies, ḷaujot šis valsts politisko režimu klasificēt kā autoritāru (The Economist, 2017). Tāpēc nav pārsteidzoši, ka valdỉba plaši kontrolē plašsazinas lïdzekḷu darbïbu (Rosefielde \& Hlouskova, 2007) un visi nozìmīgākie mediji ir kluvuši par Kremḷa pozicijas paudējiem un instrumentiem oficiālās Krievijas politikas ìstenošanā (Skillen, 2016). Šie secinājumi liek vēlreiz kritiski paraudzìties arì uz to mediju saturu, kas ir brīvi pieejami Latvijas sabiedrībai gan drukātā, gan elektroniskā veidā, un vērtēt to saistībā ar Krievijas informatīvajiem centieniem paplašināt savu ietekmi Eiropā.

Analizējot Krievijas mediju saturu laikā no 2008. gada līdz 2014. gadam, pētnieki ir izkristalizējuši vairākus vēstỉjumus, kas ir bijuši mērktiecīgi vērsti uz Latvijas sabiedrību: «Latvijā tiek diskriminēti krievvalodīgie iedzivotāji», «Latvija pārraksta Otrā pasaules kara vēsturi», «Latvija ir neveiksmīga valsts», «Latvijas Rietumu partneri nav uzticami» (Kaprāns, 2014). N̦emot vērā teorētiskajā literatūrā pieminēto plašsazinas līdzekḷ ietekmi uz sabiedrības attieksmēm un ilgo laika posmu, kurā Krievijas plašsaziṇas līdzekḷi ir snieguši minētos vēstijumus, var pieṇemt, ka tie būs guvuši zināmu izplatību Latvijas sabiedrībā.

Daži no šiem vēstījumiem jau ilgāku laiku ir cirkulējuši krievvalodīgajā mediju telpā. Piemēram, pārmetumi Latvijai par netaisnīgu attieksmi pret mazākumtautībām sākās jau 20. gadsimta 90. gados, kad aktualizējās padomju karaspēka izvešana un pilsonības jautājuma risinājumi. Arī fašisma
1. tabula. Latvijas sabiedrības atbalsts dažādiem Krievijas propagandas vēstijumiem $(\%, N=1000)$

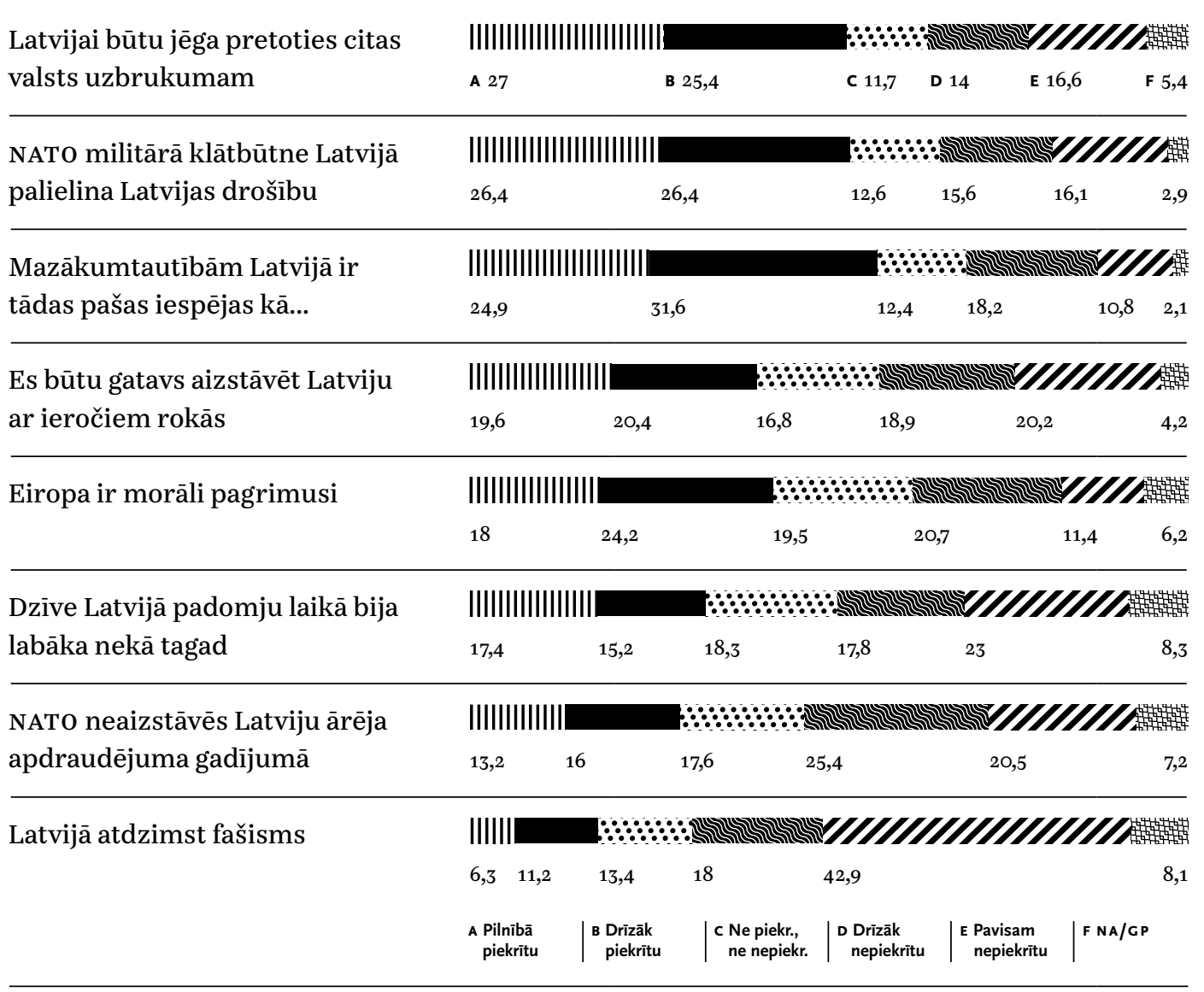

atdzimšanas tēma ir skanējusi ilgstoši, īpaši pastiprinoties ik gadu ap 16. martu, kad daḷa Latvijas sabiedrības atzimēē latviešu leğionāru piemiṇas dienu (Muižnieks \& Zelče, 2011). Savukārt tikai ap Krievijas un Ukrainas kara sākumu krievvalodīgajos medijos parādās šaubas par Latvijas militāro aizstāvamību (ja nu tāda vajadzības rastos) un NATO sabiedroto apṇēmību aizsargāa Latviju pret ārējo agresiju, neraugoties uz NATo līgumā ietvertajām saistībām.

Lai mērītu šo vēstijjumu atbalsošanos Latvijas sabiedrībā, tika formulēti vairāki apgalvojumi, kas tiešā veidā atspoguḷo vēstijumu saturu. Aptaujas dalībniekiem tika vaicāts, cik lielā mērā viṇi piekrìt vai nepiekrīt šiem apgalvojumiem. Aptaujas rezultāti liecina, ka Krievijas mediju paustie vēstijumi ir guvuši dažādu rezonansi Latvijas sabiedrībā. 
Vairāk nekā puse aptaujāto piekrīt, ka mazākumtautībām Latvijā ir tādas pašas iespējas kā latviešiem (56\%), ka NATo militārā klātbūtne Latvijā palielina Latvijas drošību ( $53 \%$ ) un ka Latvijai būtu jēga pretoties citas valsts uzbrukumam $(52 \%)$. Divi no katriem pieciem respondentiem būtu gatavi aizstāvēt Latviju ar ieročiem rokās $(40 \%)$ un uzskata, ka Eiropa ir morāli pagrimusi (42\%). Trešā daḷa respondentu domā, ka dzive Latvijā padomju laikā bija labāka nekā pašlaik (32\%) un ka NATo neaizstāvēs Latviju ārēja apdraudējuma gadījumā (29\%). Tikai $18 \%$ respondentu ir saskatijuši, ka Latvijā atdzimst fašisms.

N̦emot vērā Krievijas plašsaziṇas līdzekḷu vietu autoritārās Krievijas politikas istenošanā, ir nepieciešams pārbaudìt, vai pastāv saikne starp krievvalodīgo mediju patērinu un atbalstu noteiktiem propagandas vēstijumiem Latvijas sabiedrībā. Tā kā gan mediju patēriṇa ieradumi, gan attieksme pret noteiktiem apgalvojumiem tika mērìta, izmantojot piecu punktu Laikerta skalu, tad sakarības pārbaudei tika izmantota lineārā regresija, attieksmei pret apgalvojumiem kḷūstot par atkarīgo mainīgo. Šāda pieeja izraudzīta ar tāpēc, ka turpmākajā analīzē tiek izmantota lineārā regresija.

Regresijas analīze (2.tabula) parāda atškirīgu patērēto mediju veidu saikni ar noteiktām attieksmēm. Mediju patērinš visplašāk skaidro tieši attieksmi pret NATO klātbūtni Latvijā. Spriežot pēc regresijas koeficientiem, vislielākā nozīme ir latviešu valodā raidošo televizijas kanālu un krievu valodā raidošo televizijas kanālu, kā arī latviešu interneta portālu patērinam. Svarīgi ievērot, ka regresijas koeficienti norāda uz sagaidāmo cēlonības virzienu -latviešu mediju patērinš sekmē uzskatu, ka NATo klātbūtne palielina Latvijas drošību, bet krievvalodīgo mediju patērinš veicina pretēja uzskata izplatišanos.

Nedaudz mazāka mediju patērina nozime ir saskatāma attieksmēs pret trim apgalvojumiem: dzīve Latvijā bija labāka padomju laikā; Latvijā atdzimst fašisms; Eiropa morāli pagrimst. Visvairāk šiem apgalvojumiem iebilst respondenti, kuri bieži lasa interneta portālus latviešu valodā. Savukārt latviešu preses lasišanai un latviešu valodā raidošo televĩzijas kanālu izmantošanai te ir mazāka loma. Visnotal loğiski, ka krievvalodịo mediju aktīvākie patērētāji biežāk atbalsta šos apgalvojumus. Padomju nostalğiju mērktiecīgāk kultivē krievu valodā raidošie radio kanāli, savukārt krieviski drukātajiem medijiem labāk izdevies pārliecināt auditoriju par Eiropas morālo pagrimumu un fašisma atdzimšanu Latvijā.

Vēl mazāka mediju patēriņa ietekme ir vērojama, paužot attieksm pret gatavibu aizstāvêt Latviju ar ieročiem rokās, pret pretestỉbas jēgu, NATo neiesaistišanos Latvijas aizsardzībā, kā arī pret mazākumtautìbu līdztiesības jautājumu. Statistiski nozīmīgu noliegumu Latvijas aizstāvēšanai ar ieročiem rokās pauž vien krievu preses aktivākie lasitāji. Pretošanās jēgu statistiski nozīmīgi visvairāk noliedz krievvalodỉgo televizijas kanālu skatîtāji, 
3. tabula. Saikne starp attieksmēm, mediju patērinu un sociāli demogrāfiskajiem faktoriem

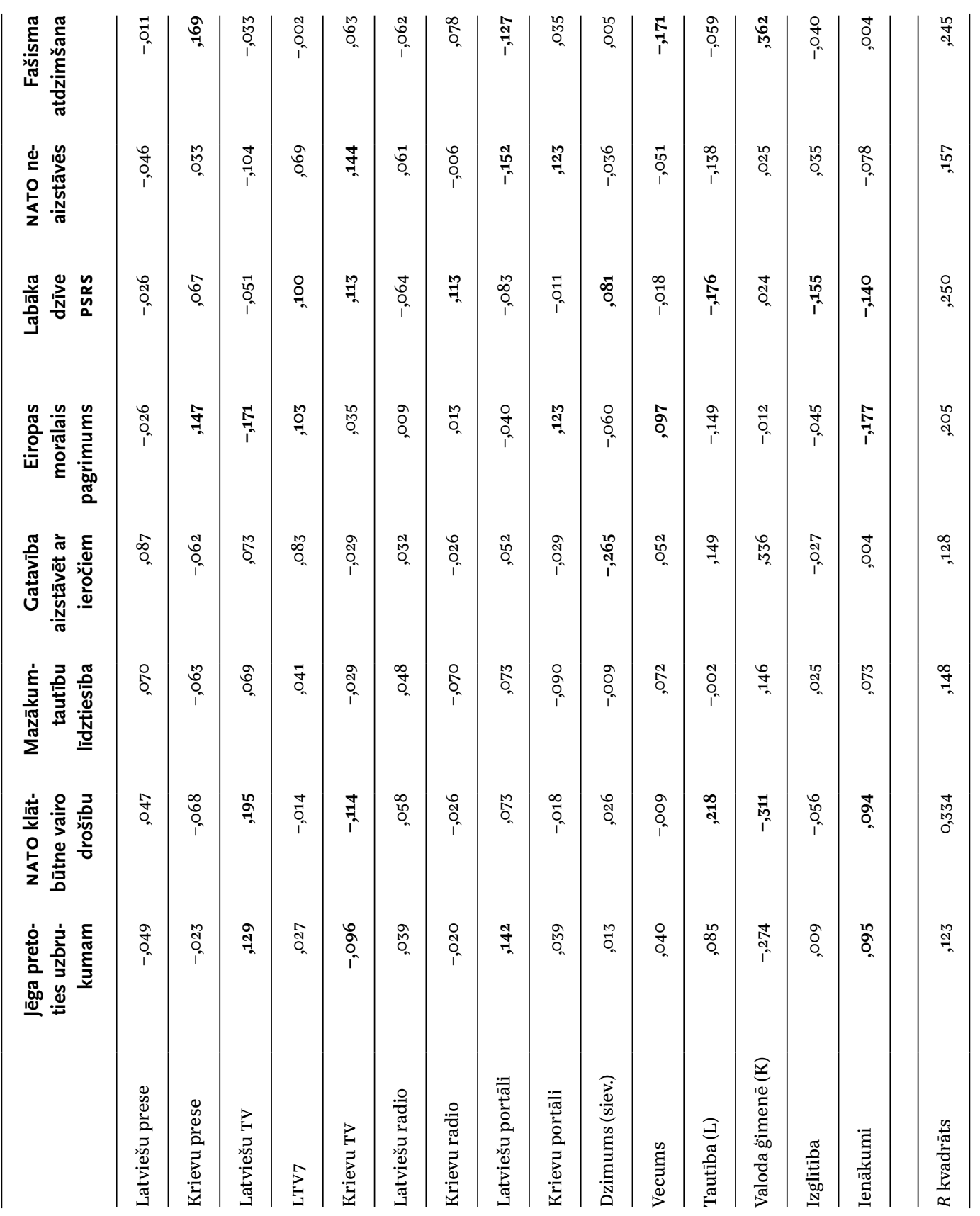

NATO neiesaistǐšanos Latvijas aizsardzībā pret ārēju apdraudējumu visbiežāk prognozē krievvalodīgo televīzijas kanālu skatītāji, bet mazākumtautību līdztiesības trūkumu visvairāk saskatijušsi krievu valodā raidošo radio kanālu klausītāji un krievu preses lasītāji. Savukārt visapnēmīgākie Latvijas aizstāvji meklējami Latvijas Televīijas 7. kanāla skatītāju un latviešu valodā raidošo radio kanālu klausītāju vidū. Pretestības jēgu visvairāk saredz un vislielāko palāvību NATo pauž latviešu portālu un latviešu televizijas kanālu skatītāii, bet mazākumtautību līdztiesību visvairāk saskata latviešu preses un latviešu portālu lasitāji.

Šì analizze norāda uz zināmu saikni starp mediju patēriṇu un indivīda attieksmēm pret valsts drošību. Tomēr ir loti svarīgi šai analīzē nemt vērā indivīdu sociāli demogrāfisko fonu. Tāpēc nākamajā regresijas analīzes modelī ir iekḷauti ne vien mediju patēinna ieradumi, bet arī virkne respondentu sociāli demogrāfisko parametru.

Salìdzinot abus modelus, redzams, ka visvairāk izskaidroto variāciju īpatsvars pieaudzis jautājumā par gatavību aizstāvēt Latviju ar ieročiem rokās. Tas skaidrojams ar dzimuma kā faktora iekḷaušanu analīzē, kas ir vienịgais statistiski nozīmìgais mainīgais šajā modelī. Būtiski, ka šajā jautājumā pēc sociāli demogrāfisko faktoru iekḷaušanas regresijas modelī savu nozìmīgumu zaudē mediju patēriňš.

Lỉdzịgas statistiskā nozīmīguma pārmainas plašā amplitūdā ir vērojamas jautājumā par NATo klātbūtni Latvijā kā drošību pastiprinošu faktoru. Tieši šajā jautājumā visskaidrāk saredzama respondenta tautības un ǵimenē lietotās valodas nozīme - latvieši biežāk uzskata NATo klātbūtni par drošību veicinošu faktoru, kamēr respondenti, kas ǵimenē pārsvarā lieto krievu valodu, ir pretējās domās. Tas varētu norādìt uz izteiktu multikolinearitātes problēmu, taču analīzes rezultāti to neapliecina. Turklāt svarīgi ievērot, ka tautība ir statistiski nozìmìga tikai vēl vienā modelī, kurā analizēta attieksme pret apgalvojumu, ka dzīve Latvijā padomju laikā bija labāka, bet ğimenē lietotā valoda ir statistiski nozīmīgs faktors, vēl tikai skaidrojot attieksmi pret fašisma atdzimšanu Latvijā. Turklāt gan respondentu tautība, gan ğimenē lietotā valoda kopumā darbojas sagaidāmajā cēlonības virzienā. Savukārt virkne faktoru, kas saistīti ar mediju patērinu, zaudē statistisko nozìmīgu mu visu astonu attieksmju analizēs.

Aplūkojot jaunieklauto faktoru lomu, redzams, ka respondentu ienākumi ir statistiski nozīmīgi četros no astoṇiem gadijjumiem, turklāt šĩ faktora ietekme ir sagaidāmajā virzienā - respondenti ar augstākiem ienākumiem ir skeptiskāki pret dzivi padomju laikā un apgalvojumu par Eiropas morālo pagrimumu; vini arī biežāk saskata jēgu pretoties uzbrukumam Latvijai un NATo klātbūtnes ieguldijjumu Latvijas drošībā. Respondentu vecuma ietekme visreljefāk saskatāma attieksmē pret fašisma atdzimšanu un Eiropas morālo pagrimumu. Tomēr kopumā ši faktora loma neškiet loti 
4. tabula. Saikne starp attieksmēm, mediju patērinu, sociāli demogrāfiskajiem faktoriem un publiskās pārvaldes darba vērtējumu

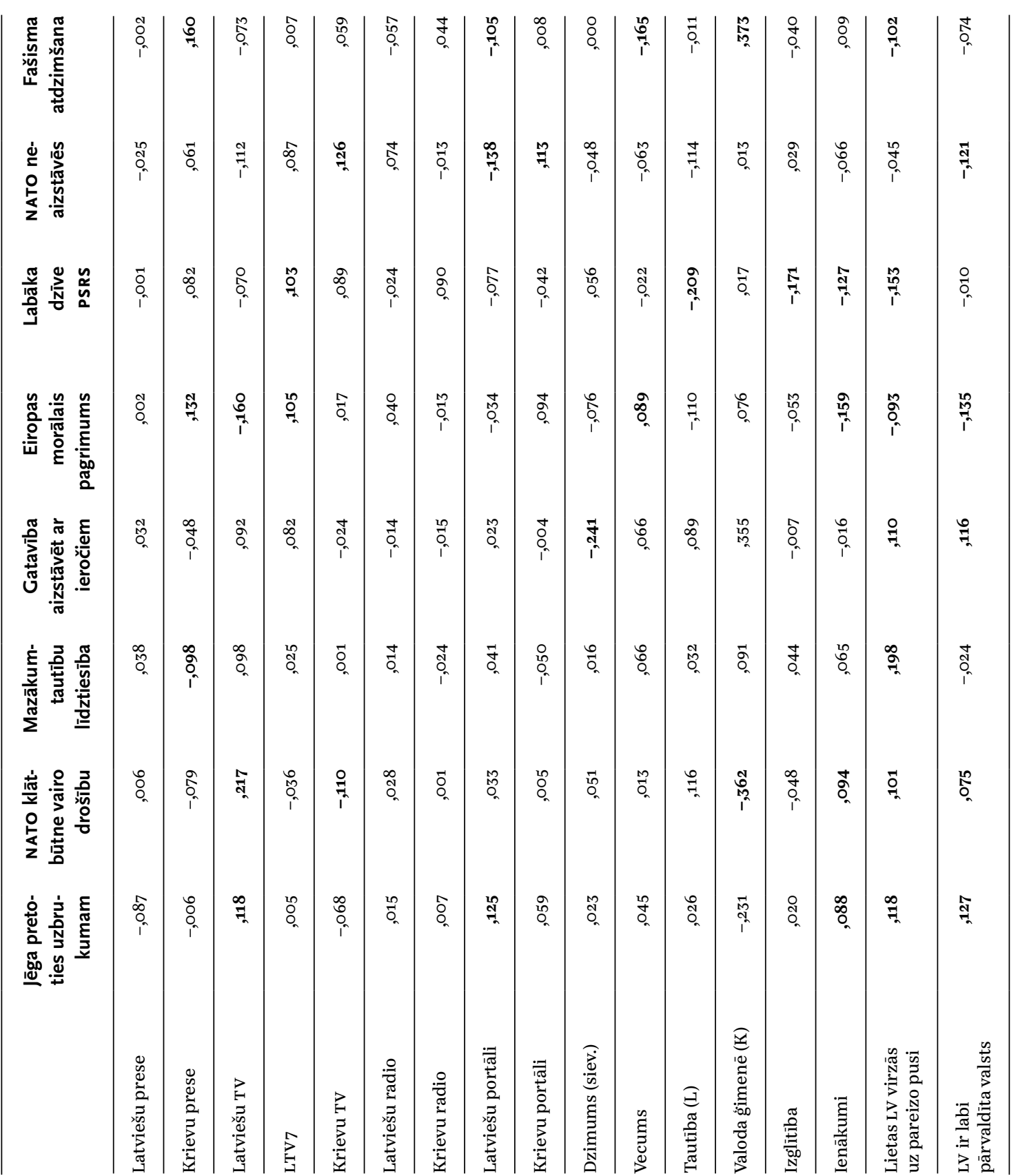

liela. Lìdzịgi maza nozīme ir respondentu formālās izglìtības līmenim, kas ir statistiski nozīmīgs vien attieksmē pret dzīvi padomju laikā, augstāk izglìtotiem respondentiem paužot negatīvāku vērtējumu. Nedaudz pārsteidzoša ir izglitīibas viegli negativaā ietekme uz priekšstatiem par NATo klātbūtnes ieguldījumu Latvijas drošībā.

No teorētiskās literatūras ir zināms, ka indivīdu priekšstati par pārvaldes sistēmas funkcionēšanu ietekmē cilvēku uzticēšanos dažādām institūcijām. Sekojot šai loğikai, regresijas analīzē tika ieklautas atbildes uz vairākiem jautājumiem, kas raksturo respondentu attieksmi pret publiskās pārvaldes darbỉbu un tās rezultātiem Latvijā.

Analīzes rezultāti liecina, ka jaunu faktoru ieklaušana palielina izskaidroto variāciju īpatsvaru. Taču vēl svarīgāk, ka publiskās pārvaldes darbības novērtējuma aspektiem ir statistiski nozīmīga loma praktiski visu pētijumā iekḷauto Krievijas vēstijumu uztverē. Visiem trim pārvaldes novērtējuma aspektiem ir statistiski nozimīga ietekme uz šãdiem viedokliem: par jēgu pretoties bruṇotam uzbrukumam Latvijai, par gatavỉbu cīnities ar ieročiem rokās, par NATo klātbūtnes pozitîvo ietekmi uz Latvijas drošību, kā arī par Eiropas morālo pagrimumu: tie respondenti, kuri pozitivāă vērtē Latvijas publiskās pārvaldes darbību, ir ievērojami mazāk uzṇēmīgi pret Krievijas propagandas vēstijumiem par Latvijas drošỉbas situāciju. Atsevišķi pārvaldes novērtējuma aspekti iespaido arī respondentu attieksmi pret citiem Krievijas vēstijjumiem. Piemēram, sajūta, ka lietas Latvijā virzās uz labo pusi, vājina priekšstatus par mazākumtautību nelīdztiesīgumu un fašisma atdzimšanu valstī, kā arī vedina kritiskāk raudzìties uz dzìvi Latvijā padomju laikā. Uzskats, ka Latvija ir labi pārvaldìta valsts, mazina šaubas par NAT0 palīdzību Latvijas apdraudējuma gadỉjumā.

Viens no šì pētijuma uzdevumiem ir analizēt vērtīborientāciju saikni ar uznēmibu pret Krievijas propagandas vēstijumiem. Tāpēc regresijas analizzē tika iekḷautas arī no Šaloma Švarca teorijas atvasinātās vērtību dimensijas.

Analīzes rezultāti liecina, ka Švarca vērtīborientācijām ir pavisam neliela ietekme uz respondentu attieksmēm. Statistiski nozimiga saikne saskatāma konformitātes un pašrealizācijas vērtībām ar uzskatiem par jēgu pretoties uzbrukumam Latvijai. Kā izriet no teorētiskajiem pieṇēmumiem, abas šis vērtības mazina pretošanās jēdzịgumu. Fašisma atdzimšanu biežāk ir saskatijušsi respondenti, kuriem vairāk raksturīga sasniegumu vērtīborientācija. Respondenti, kuriem raksturīgāka ir stimulācija un patstāvīgums (self-direction), biežāk saskata mazākumtautību līdztiesīgumu Latvijā. Savukārt uz varu un sasniegumiem vērstie respondenti retāk piekrīt tēzei par Eiropas morālo pagrimumu.

Svarīgi, ka regresijas analīzes modeḷi, kuros nav iekḷauti mediju patērina ieradumi, taču ir saglabātas gan vērtỉborientācijas, gan sociāli demogrāfiskie faktori, gan arī publiskās pārvaldes novērtējums, neuzrāda 
5. tabula. Saikne starp attieksmēm, mediju patērinu, sociāli demogrāfiskajiem faktoriem, publiskās pārvaldes darba vērtējumu un vērtīborientācijām

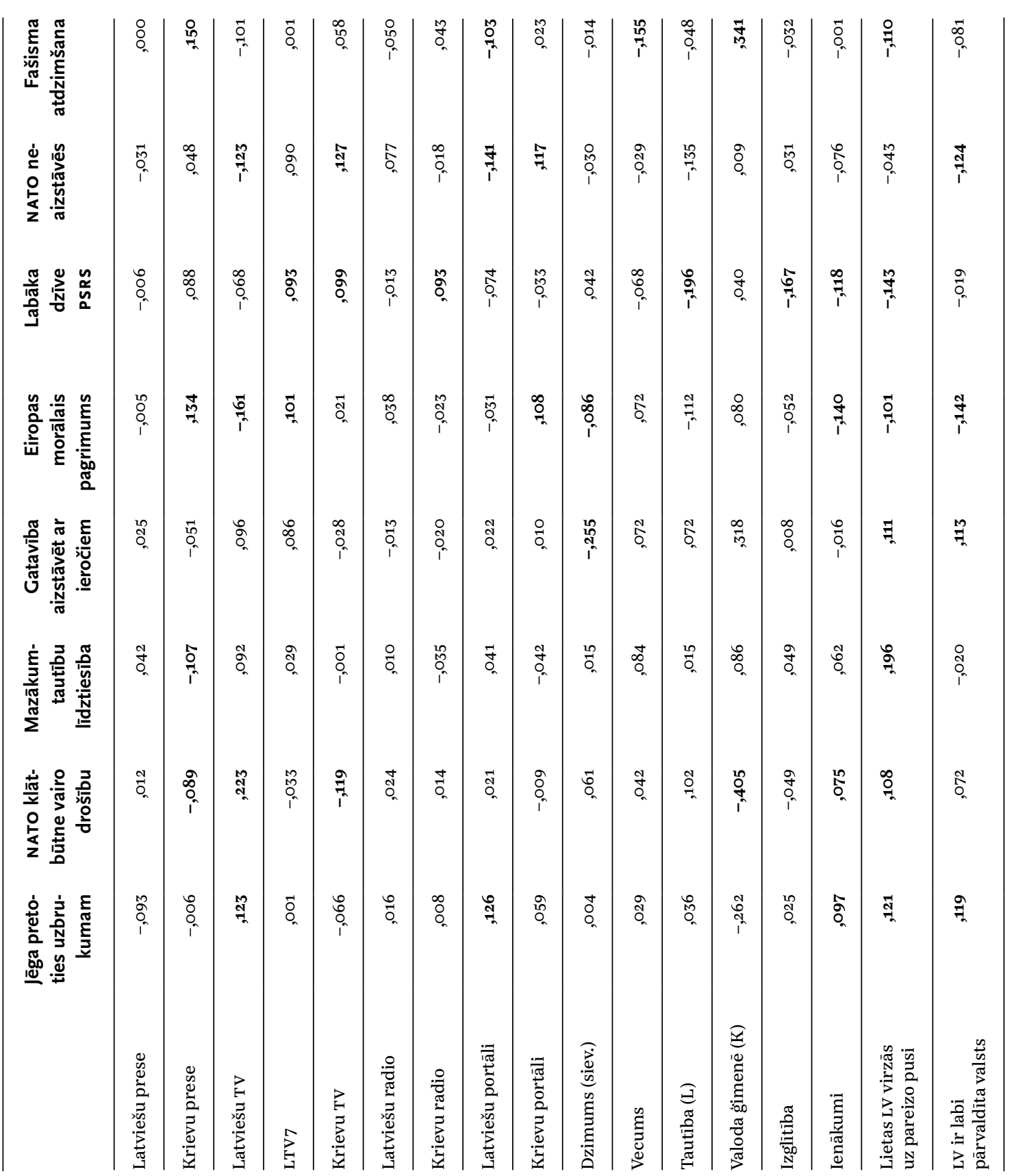

6. tabula. Saikne starp

publiskās pārvaldes darba

vērtējumu un attieksmēm

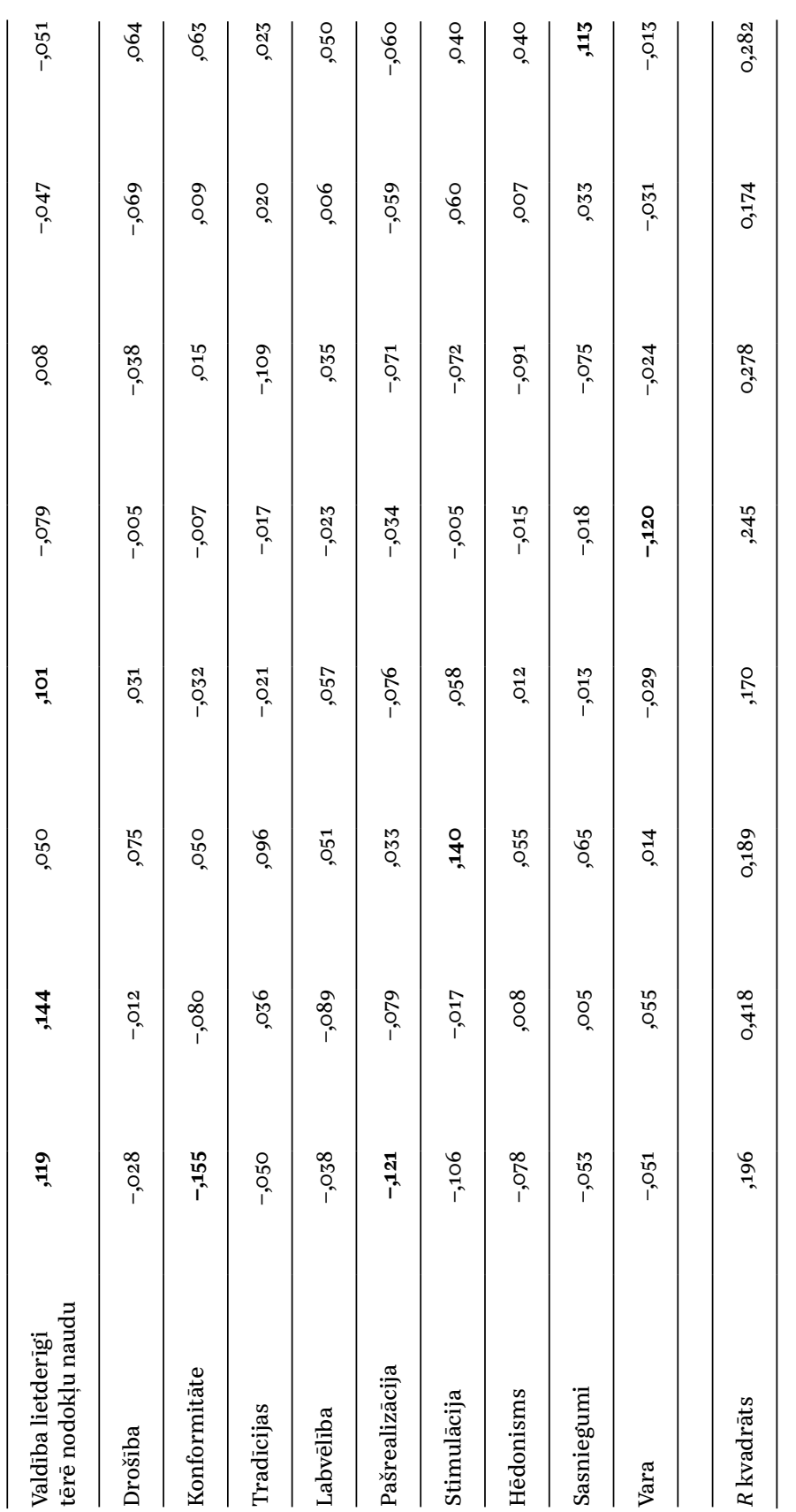


būtiskas izmainas vērtīborientāciju lomā. Savukārt regresijas analīzes modeḷi, kuros iekḷauti tikai publiskās pārvaldes novērtējuma aspekti un attieksmes pret Krievijas propagandas vēstījumiem, uzrāda salīdzinoši neviendabīgus rezultātus.

Publiskās pārvaldes darbības novērtējums izskaidro tikpat daudz vai pat vairāk variāciju nekā mediju patēriṇš jautājumos par jēgu pretoties un gatavibu aizstāvēt Latviju ar ieročiem rokās. Savukārt mediju patēriňš ir labāks skaidrojošais faktors uzskatiem par NATo klātbūtni kā drošību pastiprinošu elementu, par fašisma atdzimšanu un priekšstatiem par dzivi Latvijā padomju laikā.

\section{Secinājum}

Latvijas sabiedrība ir bijusi atvērta Krievijas plašsazinas līdzekliem gan vēsturis-

ku, gan lingvistisku, gan kultūras apstāklu dēl. Krievijas un krievu valodā funkcionējošo mediju patēriņš Latvijā ir prāvs, turklāt to neierobežo etniskā piederība, jo krievu valodas zināšanas joprojām ḷauj ievērojamai etnisko latviešu dalai izmantot šos medijus, kuri turklāt ir visai vienkārši pieejami kā kabeḷtelevizijāā, tā arī citos elektroniskajos un drukātajos formātos.

Jau kopš 20. gadsimta 90. gadu sākuma Krievija ir veidojusi noteiktu narativvu par Latvijas valsti un tās attieksmi pret mazākumtautībām, īpaši jau pret austrumslāviem. 21. gadsimtā šis narativvs tiek paplašināts un padziḷināts, izmantojot jēdzienu «krievu pasaule». Savukārt kopš Krievijas un Ukrainas kara sākuma 2014. gadā Krievija pastiprināti cenšas pārliecināt Latvijas iedzivotājus par to, ka, no vienas puses, Latvija ir kopumā neizdevusies valsts, kas maz rūpējas par saviem iedzīvotājiem, bet, no otras puses, Latvijai nav nekādu izredžu nosargāt savu neatkarību militāra konflikta gadỉjumā ar Krieviju. To nosakot gan militāri, gan politiski apsvērumi.

Ši pētījuma ietvaros tika analizēts, cik lielā mērā šãdi Krievijas vēstījumi, kas tiek piedāvāti Latvijas sabiedrībai, ir raduši atbalsi Latvijā un kādi faktori veicina vai slāpē atsaucīgumu Krievijas propagandas stāstiem. Pètījuma empīriskā dąla balstās uz 2015. gadā veikto Latvijas iedzìvotāju aptauju.

Regresijas analīzes modeḷi rāda, ka mediju patēriņš ietekmē zināmu dalu Latvijas sabiedrībā pastāvošo uzskatu par aktuāliem valsts drošỉbas jautājumiem, skaidrojot starp $6 \%$ un $31 \%$ variāciju. Mediju patērinam ir nozīme arī senāku Krievijas vēstijumu uztverē par Latviju - mediju patēriņš skaidro starp $12 \%$ un $21 \%$ variāciju. Turklāt mediju patērina empīriskais ietekmes virziens atbilst sagaidāmajam - mediji latviešu valodā sekmē proatlantisku uzskatu izplatību, bet krievvalodīgo mediju patēriņš ir saistīts ar Kremlim labvēligu uzskatu paušanu.

Tomēr plašsazinas lïdzekḷu ietekme nebūtu pārspīlējama. Papildinot regresijas analīzi ar citiem neatkarīgajiem mainīgajiem, mediju patērina loma mazinās un virkne mediju faktoru zaudē statistiski nozīmīgu ietekmi. Piemēram, analīzē iekḷaujot vairākus sociāli demogrāfiskos parametrus (dzimums, vecums, izglitîba utt.), daudzi mediju patēriṇa rādītāji zaudē statistisko nozìmïgumu. To varētu skaidrot ar multikolinearitāti starp mediju patērinu, no vienas puses, un tautību un ǵimenē lietoto valodu, no otras puses. Tomēr analīzes gaitā tāda netika identificēta. Vēl vairāk - analīzē iekḷaujot tikai mediju patēriņa un publiskās pārvaldes darbības novērtējuma neatkarīgos mainīgos, daudzi mediju patēriṇa rādītāji jau atkal zaudē statistisko nozìmīgumu.

Aplūkojot šai nodaḷā iekḷautos regresijas analīzes modeḷus, ir redzams, ka pret Krievijas propagandas vēstijumiem uznēmigāki ir tie respondenti, kuri ne tikai pastiprināti izmanto krievvalodīgos plašsaziņas līdzekḷus, bet arī ir neapmierinātāki ar Latvijas publiskās pārvaldes darbību. Turklāt apmierinātībai ar valdības darbu bieži vien ir lielāka ietekme uz respondentu uzskatiem nekā mediju patērinam. Ja runa ir par verbalizētu apnēmìbu ar ieročiem rokās pretoties uzbrukumam Latvijai, tad šai jomā valdỉbas darba novērtējumam ir īpaši labi saskatāma nozīme.

Citu sabiedrību pieredze mudina domāt, ka îstermiṇa faktoru (piemēram, valdības darba vērtējums) ietekmi iespējams kompensēt ar dziḷākiem, ilgtermiņa faktoriem, kas saistīti ar indivīda pamatvērtỉbām. Taču jāatzīst, ka Latvijas gadijjumā nav saredzama liela vērtīborientāciju ietekme uz indivìdu uzskatiem par Latvijas drošǐbu.

Kopumā šie pētijuma rezultāti lielos vilcienos apstiprina agrāk veikto pètijumos saknotās gaaidas par Latvijas sabiedrỉbas uzskatu genenēzes cēlonibas virzieniem un vairāk nekā parasti akcentē valdības darbïbas lomu valsts drošības situācijas uzlabošanā. Vienlaikus šis pētijums sniedz jaunus pierādijumus par Krievijas mediju ierobežoto ietekmi ārvalstīs. 


\section{Anomija demogrāfijas kontekstā. \\ Anomijas un sociālo faktoru \\ ietekme uz reproduktivajiem \\ nodomiem un to realizāciju}

Pēdējie 25 gadi Latvijā demogrāfijas jomā asociējas ne tikai ar novecošanos, iedzīvotāju skaita samazināšanos un emigrāciju, bet arī ar kvalitativā̄m sabiedrības izmaiṇām: pieaugusi nereǵistrēta kopdzive kā alternatīva laulībai, samazinājusies dzimstība, daudz lielāks ir ārpus laulības dzimušo bērnu skaits. Šìs nodalas mērkis ir apkopot un apskatît svarīgākos faktorus, kas ietekmē reproduktīvo uzvedỉbu Latvijā un citur Centrāleiropas un Austrumeiropas valstīs (turpmāk-CAE valstis), tādi ir ekonomiskā neskaidrība, sociālā anomija, otrā demogrāfiskā pāreja, kā arī dzimumu nevienlīdzība. İpaša uzmanība pievērsta demogrāfijas literatūrā maz pētītam faktoram - anomijai: vai anomisks sabiedrības stāvoklis var izskaidrot demogrāfisko procesu izmainas, kas notikušas un notiek Latvijā - nelielo vēlamo un nelielo realizēto bērnu skaitu ğimenē. Tāpēc nodalā vispirms definēta anomija un anomiska situācija, bet turpinājumā apskatìta demogrāfiskā literatūra, lai analizētu, starp kādiem faktoriem ierindojas anomija un kādā veidā tā ietekmē demogrāfisko izturēšanos. Šì nodala piedāvā analītisku diskusiju par dažādu sabiedrības lìmeņa faktoru ietekmi uz reproduktīvajiem nodomiem un ìstenoto bērnu skaitu.

Anomijas koncepcija cēlusies no socioloǵijas zinātnu disciplīnas un demogrāfisko jautājumu kontekstā parasti netiek pētīta. Anomija kā sociāls fenomens pēdējo gadu laikā tiek pētìta un analizēta salīdzinoši bieži, ìpaši socioloğijas un politikas sfērās. Savukārt maz tiek pētìta anomijas ietekme uz demogrāfiju jeb demogrāfisko uzvedību - kā individi pienem lēmumus par tādām dzīves sfērām kā partnerattiecību veidošana un bērnu radī̌nana.

Mūsdienu attīstīto valstu sabiedrībās notiek nepārtrauktas izmainas globalizācija, strauja tehnologóiskā attīstība, ekonomikas un vides pārmaiṇas. CAE valstis nesenā pagātnē pieredzējušas vēl straujākas izmaiṇas, kas saistītas ar politiskās sistēmas maiṇu un vairākām ekonomiskām krīzēm, kas novedušas arī pie sabiedrības noslānošanās un ienākumu nevienlïdzības. Šādas pārmainas nesušas līdzi sociālo normu un vērtību izmaiṇas gan sabiedrības, gan individuālā līmenī (Ḷevina, Mārtinsone, \& Klince, 2016).

Kopš 9o.gadu sākuma CAE valstis ir pieredzējušas krasu dzimstības samazināšanos. Summārais dzimstības koeficients (Total Fertility Rate) ir noslīdējis līdz ḷoti zemam līmenim - 1,3-1,5 bērni uz vienu sievieti. Latvijā šis rādītājs 2016. gadā bija pakāpies līdz 1,8, bet 90. gados arī Latvija pieredzēja kritiski zemu dzimstību. Šo kritumu pavadïjis straujš mātes vecuma pieaugums pēc bērna dzimšanas secības, kas norāda uz spilgti izteiktu bērnu radišanas laika atlikšanu (Philipov \& Kohler, 2001; Sobotka, 2003a, 2003b; Philipov \& Dorbritz, 2003). Daḷa demogrāfu mēóginājuši šīs izmainas skaidrot, uzsverot ekonomiskos faktorus, bet citi akcentē ideoloğiskās pārmainas. No ekonomiskā viedokḷa strauja un intensīva ekonomiskā restrukturizācija ir palielinājusi gan tiešās, gan netiešās izmaksas saistībā ar bērnu radīšanu. Arī ekonomiskā neskaidrība vienlaicīgi ar masīvu sabiedrības transformāciju 
atstājusi sekas. Ideoloğisko izmainu ietekmes ierosinātāji norāda, ka totalitāro režìmu gāšana veicināja jaunu vērtību ieplūšanu sabiedrības domāšanā, kas raksturīga demokrātiskām sabiedrībām, un tas savukārt veicinājis otro demogrāfisko pāreju CAE valstīs (piemēram, skat. United Nations, 2002). Cits pētijumu virziens uzsver kopigo ekonomisko un sociālo faktoru ietekmipiemēram, Kolers (Kohler et al., 2002) uzsver augstākās izglītỉbas atdeves negatīvo ietekmi uz dzimstību jeb dzimstības atlikšanu. Autors arī pastiprināti uzsver sociālo normu izmainu svarīgumu un apraksta mehānismu, caur kādiem kanāliem šie mainītie standarti ietekmē demogrāfisko uzvedỉbu pieaugošā iedzīvotāju dạ̣ā. Šie minētie pētỉjumi ir balstîti uz makrolīmena datiem. Diemžēl sabiedrības transformācijas periodā nebija atbilstošu demogrāfisko apsekojumu, kas būtu izmantojami, detalizētāk pētot dzimstības lēmumu pieṇemšanu. Neskatoties uz it kā lielo pētijumu apjomu par šo tēmu, loti maz ir zināms par indivìdu lēmumiem, kas noved pie zemākas reālās kopējās dzimstības, kā arī pie mazāka vēlamā bērnu skaita ǵ̛imenē CAE valstīs, tai skaitā Latvijā.

Latvija, tāpat kā citas CAE valstis, ir pieredzējusi būtisku sabiedrības transformāciju. Sākot ar ekonomikas sabrukumu, kad iekšzemes kopprodukts 9o. gados nokritās tālu zem 1989. gada līmeņa, sabiedrība pieredzēja hiperinflāciju, industrijas sabrukumu un iepriekš nepieredzētas bezdarba situācijas. Padomju gados iegūtā izglìtỉba daudzos gadỉjumos izrādījās nepiemērota brīvā tirgus ekonomikai un jo vairāk straujajai tehnoloğiskajai attīstỉbai un globalizācijai. Tādēl pārejas gados, arī pateicoties liberalizētam izglītības tirgum un studiju iespējām par privātiem līdzekḷiem, studentu skaits pieauga vairākas reizes - augstskolu skaits pieauga no 12 iestādēm 1990. gadā līdz 33 augstākās izglìtỉbas iestādēm 2000. gadā, studentu skaits attiecigi - no 46000 lïdz 101300 , t. i., 453 studenti uz 10000 iedzivotājiem, kas bija ne tikai viens no augsstākajiem rādītājiem Eiropas Savienībā, bet arī pasaulē (IZM, 2001).

Summārais dzimstības koeficients 1986. un 1987. gadā bija 2,2 bērni uz vienu sievieti, kas nedaudz pārsniedza pienemto dabiskās sabiedrïbas atjaunošanās līmeni 2,1 (CSP Demogrāfija, 2016). 90. gados tas krasi samazinājās lìdz ārkārtīgi zemam lìmenim, proti, 1,1-1996.-1998. gadā (CSB, 2016). Pēdējos gados rādītājs ir palielinājies, tomēr tas joprojām nesasniedz minimālo sabiedrïbas atražošanas limmeni.

Kopš neatkarības atjaunošanas ir pieaudzis sievietes vidējais vecums, noslēdzot laulību, un mātes vidējais vecums, piedzimstot pirmajam bērnam. 1990. gadā mātes vidējais vecums, piedzimstot pirmajam bērnam, kā arī vidējais vecums, noslēdzot pirmo laulību, bija 23 gadi. 2015. gadā sieviete vidēji stājās laulībā 28 gadu vecumā un, piedzimstot pirmajam bērnam, bija 26 gadus veca. Vēl lielāks ir vecums, ja apskata visu laulību noslēgšanas laiku - sieviete dodas laulībā vidēji 33 gadu vecumā (CSB, 2016). Šìs dzives cikla pārmaiṇas saistītas gan ar ilgāku izglìtošanās periodu (vairāk iedzīvotāju, īpaši sieviešu, iegūst augstāko izglitīibu), gan vēlmi iekārtoties darba tirgū un izveidot karjeru pirms bērnu nākšanas pasaulē. Likumsakarīgi, ka pārmaiṇas saistītas arī ar vērtību izmainām sabiedrībā.

\section{Anomija kā parādība}

Anomijas jēdzienam ir jāizšķir mikrolī-

menis jeb individa limenis, kur centrä ir indivīds un tā atsvešināšanās no sabiedrības (Srole, 1956; Ḷevina et al., 2017), un makrolīmenis jeb sabiedrības līmenis, kas attiecas uz integritātes trūkumu sabiedrībā kopumā. Ang̣̣u valodā tos apzīmē ar atškirīgiem terminiem anomie sabiedrības anomijai un anomia indivìda situācijas raksturojumam. Atšķiirīgais skatījums redzams arī definīcijās - saskaṇā ar Kembridžas vārdnīcu anomija ir «stāvoklis, kurā personai vai sabiedrībai neeksistē morālì vai sociāli principi» (Walter, 2008). Lìdzịgi Kembridžas psiholoğijas vārdnīca definē anomiju kā «atsvešināšanos no sabiedrības un bezcerības stāvokli, ko izraisa straujas sabiedrības pārmaiņas un īpaši izmaiņas vērtībās un uzskatos» (Matsumoto, 2009, p. 40). Merriam-Webster vārdnīcā anomija ir «sociālā nestabilitāte, kas radusies standartu un vērtību sabrukšanas rezultātā (Merriam-Webster, 2017; Durkheim, 1964). Tā var nozīmēt arī sabiedrības morālo standartu neesamību, personīgo izolētỉbas stāvokli un nedrošību, kas radusies sociālās kontroles un regulējumu trūkuma dēl. Attiecīgi anomiju var definēt un apskatīt kā «sabiedrības stāvokli» vai kā «prāta stāvokli». Demogrāfijas kontekstā nav tik svarīgi stingri izšḳirt mikro-makro perspektīvu, bet kopumā vērtēt tās ietekmi.

Anomiju var analizēt no divām perspektīvām saskaṇā ar Dirkemu (Durkheim, 1964) vai Mērtonu (Merton, 1966). Saskaṇā ar Dirkema oriǵ̛inālo 1951. gada skatpunktu (Durkheim, 1964, 1966) anomijas stāvoklì ar likumu noteiktās normas ir pavājinātas vai zudušas un cilvēki zaudē orientāciju, plānojot savas dzīves notikumus. Sekas ir dezorientācija dzivēē un vispārēja neskaidrība. Ši iemesla dēl atseviški cilvēki var sastapties ar mentālā stāvokla pasliktināšanos un ekstrēmākos gadijjumos nonākt depresijā un apsvērt dzives vērtību un pašnāvỉbu.

Mērtons (Merton, 1966) savukārt skata anomiju plašākā kulturālo struktūru un sociālo sistēmu kontekstā. Indivīdi nosaka savus mērkus un vēlmes kultūrsociāāās struktūras ietvaros, bet harmonijas trūkums starp mērḳiem un iespējām tos sasniegt rezultējas anomiskā sabiedrībā. Disharmonija starp mērḳiem un iespējām tos sasniegt makrolīmenì izraisa normu neievērošanas pieaugumu, bet mikrolīmenī provocē neuzticēšanos institūcijām. Tādējādi cilvēki, kas noraida normas, var rỉkoties anomāli, piemēram, pievērsties kriminālām darbībām, bet cilvēki, kas sev uzstāda noteiktus mērkus saskanā ar savu kulturālo vidi, var nebūt spējịgi šos mērkus sasniegt sociālās 
sistēmas zemas efektivitātes dēl. Šĩ otrā grupa nepieṇem sociālo realitāti un jūtas atsvešināti. Likumsakarīgi, ka anomija pieaug sabiedrībā, kurā notiek straujas pārmaiṇas un kur šīs transformācijas strauji paaugstina labklājỉbas lìmeni un mainās iedzìvotāju sociālie stāvokḷi. Vienalga, vai skatāmies no Dirkema vai no Mērtona viedokḷa, anomijas rezultātā cilvēki var sajust orientācijas trūkumu, nedrošỉbu, bezspēcību, vientulību un psiholoğisku diskomfortu. Abi pētnieki ir vienisprātis, ka anomijas iemesli meklējami sabiedrībā, nevis indivīdā. Anomija tādējādi ir sociāli strukturāls fenomens, kas izpaužas sabiedrības locekḷu uzvedībā.

Akadēmiskā literatūrā anomija kā sabiedrības stāvoklis visbiežāk tiek pētìta valstīs, kur notiek (vai notikušas) radikālas strukturālas pārmaiṇas un ir politiska nestabilitāte (piemēram, valsts iekārtas maiņa kā CAE valstīs laikposmā no 1991. lỉdz 2000. gadam), valstīs, kas saskaras ar būtiskām sociālām un ekonomiskām krīzēm, valstīs, kurās notiek karadarbība vai sociāli nemieri, kā arī valstīs un sabiedrībās, kurās it kā ir augsts labklājỉbas līmenis, bet vienlaicīgi arī liela vai pieaugoša nevienlīdzība (ASv).

Anomijas mērišanai tiek lietoti vairāki instrumenti. Viens no pirmajiem, kas piedāvāja instrumentu anomijas mērišanai, bija Leo Srole jau 1956. gadā. Sroles anomijas skalā bija pieci vispārēji attieksmes jautājumi. Vēlāk šì skala un pieeja tika kritizēta, bet uz tās pamata veidotas jaunas, mūsdienu sabiedrībai un situācijai piemērotākas mērišanas metodes. Viens no jaunākajiem un nopietnākajiem mēǵinājumiem mērīt anomiju ir A.Teimūra vadīiās pētnieku grupas projekts Anomijas uztveres skala (Perception of Anomie Scale-PAS) (Teymoori et al., 2016). Šì skala aptver divus pamata anomijas pamatjēedzienus, ko identificējis Dirkems (1964) - uztveri par sociālās struktūras sabrukšanu un par vadỉbas sabrukumu. Katrs no faktoriem tiek mērìts ar sešiem rādītājiem. Izstrādātais instrumentārijs ir efektîvs, un tā validitāte šajā projektā tiek pārbaudīta 28 valstīs, t. sk. Latvijā, kontrastējot to ar ekonomiku un sabiedrību raksturojošiem rādìtājiem (piemēram, Tautas attīstības indeksu, IKP, Korupcijas uztveres indeksu u.c.), kur tas izrādījies precīzs. Taču šis instrumentārijs ir prasīgs datu iegūšanas ziṇā.

Ḷevina, Martinsone un Klince (2016) nesenā pētijumā par saistību starp individuālo anomiju un vērtībām Baltijas valstīs modelēja anomiju kā daudzdimensionālu konceptu, kas balstās uz trim dimensijām: normu neesamỉbu, sociālo izolāciju un jēgas neesamību. Pētijumā tas tika konceptualizēts un mērīts ar Eiropas vērtỉbu pārskata (European Values Survey) jautājumu palīdzību.

\section{Dzimstību}

ietekmējošie faktori
Dzimstība ir kompleksu individa lēmumu rezultāts. Literatūrā par demogrāfiju uzskaitits plašs faktoru loks, kas ietekmē indivīdu reproduktīvos nodomus un to realizāciju. Vienlaicīgi maz ir zināms par indivīdu lēmumiem, kas noveduši pie zemās kopējās dzimstības un dzimstības atlikšanas CAE valstīs. Šajā nodạ̣ā apkopoti faktori un to skaidrojumi, kas ietekmē dzimstību. Atseviški tiek apskatìts katrs faktors, un Latvijas kontekstā vērtēta tā ietekme. Vispirms tiek vērtēta reproduktîvo nodomu un to realizācijas savstarpējā saistība, kam seko citi literatūrā balstīti faktori: ienākumu līmenis jeb plašākā kontekstā-ekonomiskā situācija, indivīdu izglìīiba, vērtību sistēma, politika un anomija.

VĒLAMAIS BĒRNU SKaITS UN DZIMSTīBa Vēlamais un realizētais bērnu skaits ğimenē visbiežāk ir atškirịgs. Apsekojumos tiek atseviški definēti arī «vispār ideālais», «personīgais ideālais», «plānotais» un «reālais jeb realizētais» bērnu skaits. Sabiedrībā vēlamais bērnu skaits vienmēr pārsniedz reālo bērnu skaitu, kaut individuālā līmenī var būt arī otrādi.

Vidēji ES ideālais bērnu skaits (Eurobarometer, 2011) ir 2,2 bērni vïriešiem un 2,3 bērni sievietēm, pārsniedzot dabīgo ataudzes līmeni lielākajai daḷai valstu, bet reālais summārais dzimstības koeficients (vienai sievietei dzimušo bērnu skaits dzīves laikā) ir 1,6-1,7 robežās. Latvijā, pretēji ES, pēc sieviešu domām, ideālais bērnu skaits ir 2,2, bet vīriešu - 2,3 bērni (OECD Family Database), turklāt sievietēm ar augstāko izglìtỉbu ideālais bērnu skaits ir lielāks nekā sievietēm ar zemāku izglìtību. Starp OECD valstīm Latvijā ir lielākā atškirība starp novērtēto vispārīgo un personīgo ideālo bērnu skaitu, kaut vidēji OECD un ES valstīm šì atšķirība ir negatĩva. Tas norāda uz Latvijas situācijas paradoksu, ka it kā lielāks skaits bērnu ir labi, bet «ne priekš manis». Tas var norādìt uz anomijas situāciju jeb konfliktu starp vispārīgām normām un indivìda uzskatiem.

Kā norādīts zinātniskajā literatūrā par demogrāfiju, mūsdienu Rietumu sabiedrībā vēlamais bērnu skaits ir galvenais noteicošais faktors reālajām vēlmēm radīt bērnus. Viens no teorētiskajiem pamatojumiem saistỉbai starp nolūkiem (šajā gadījumā-nolūku ğimenē radīt noteiktu skaitu bērnu) un rīiību ir plānotās uzvedības teorija (Theory of planned behaviour) Saskanāa ar šo teoriju rīcību vada nodomi, ko savukārt ietekmē subjektīvās normas, attieksmes (plānotais bērnu skaits) un kontroles mehānismi (skat., piemēram, Ajzen, 1991). Lỉdz ar to nodoms var tikt uzskatìts par tuvāko uzvedības noteicēju; un faktoriem, kam ir ietekme uz nodomiem, ir ietekme ari uz reālo rīcību. Pretējs virziens var nebūt patiess, starp nodomiem un reālo rīcību pastāv dažādi šḳērṣ̌ıli.

Literatūrā atrodama kritika par reproduktīvo nodomu izmantošanu kā dzimstību prognozējošo faktoru galvenokārt tāpēc, ka noteikta daḷa no reproduktīvajiem nodomiem paliek nerealizēta (piemēram, Quesnel-Vallée \& Morgan, 2003). Neizbēgami starp nodomu un tā realizāciju paiet zināms laiks, un šajā periodā nodomi var mainīties uz pozitīvu vai negatīvu pusi. Morgans 
(Morgan, 2003) atsaucas uz šìm izmaināam kā nodomu «pārskatîšanu». Tomēr Viljamss ar kolēǵiem (Williams et al., 1999), izmantojot ASV apkopotos datus, parādīja, ka nodomi, kas attiecas uz konkrētu laika intervālu (piemēram, nākamajos divos gados), ir labs individuālās rīcības rādītājs.

Vēlamais bērnu skaits jeb nodomi radīt bērnus kā dzimstỉbu paredzošs un atspoguḷojošs rādītājs jāuztver piesardzīgi vēl citu iemeslu dēḷ. Pirmkārt, reproduktīvie nodomi nav stabili attiecībā uz laiku un vecumu. Piemēram, cilvēkiem ir tendence samazināt vēlamo ğimenes lielumu, paliekot vecākiem (Liefbroer, 2009), bet arī viena vecuma cilvēki, aptaujāti dažādos gados, bieži norāda atšķirìgu vēlamo ǵimenes lielumu (Quesnel-Valle \& Morgan, 2003; Heiland et al., 2008 u.c.). Tāpat dala bērnu nav bijusi sākotnēji plānota.

Kopumā jāsecina, ka empiriskos aprēķinos vēlamais bērnu skaits nav izmantojams kā reāls dzimstību atspoguḷojošs rādītājs, bet atšḳiiība starp nodomāto un realizēto bērnu skaitu var sniegt nozīmīgu informāciju, īpaši salïdzinot starp valstìm vai periodiem. Vienlaicīgi faktori, kas ietekmē vēlamo un realizēto bērnu skaitu, ir vieni un tie paši, secīgi ietekmējot vispirms vēlamo un, izejot no tā, arī reālo sasniegto ǵimenes lielumu. Tātad teorētiskā diskusijā var aproksimēt dzimstỉbu gan ar vēlamo, gan ar reālo bērnu skaitu, kā arì tiek darìts turpmāk.

EKONOMISKIE FAKTORI UN IZGLīTīBa Makroekonomiskā līmenī pastāv stipra statistiski nozīmīga negatīva korelācija starp ienākumiem un dzimstību - jo augstāks ir ienākumu limmenis uz vienu cilvēku, jo zemāka ir dzimstība, kā arī ǵimenēs ar augstākiem ienākumiem ir mazāk bērnu. Šìs attiecības pamatā ir virkne dažādu faktoru, starp kuriem galvenais ir izglītības limmenis. Savukārt individuālā līmenī no ekonomikas teorijas viedokḷa bērnu skaits, tāpat kā ienākumi - gan tiešie, gan netiešie -, ir dala no katra indivìda derīguma līknes (utility function). Šajā funkcijā bērni ieklaujas gan kā izdevumu avots, gan arī vienlaicīgi kā faktors, kas paaugstina labklājỉbu.

Vienlaikus indivīdam ir jāizdara dinamiska izvēle, jo bērna radišana ir ierobežota laika posmā. Dinamiskie mikroekonomiskie dzimstïbas modeli (piemēram, Arroyo \& Zhang, 1997; Hotz et al., 1997) analizē notikumu secibu, kurā viens no notikumiem ir bērna piedzimšana. Parasti dzives laikā kḷū̌̌ana par vecākiem seko pēc izglitīibas iegūšanas. Ja bērna piedzimšana notiek studiju laikā, tas var būt par iemeslu mācību pārtraukšanai (Billari \& Philipov, 2004). Tādējādi augsstskolu studentu skaita pieaugums augstākās izglītības sektorā Latvijā var izskaidrot ievērojamu dạı no dzimstības samazināšanās un vidējā mātes vecuma pieauguma kopš 20.gss. 90. gadiem. Turklāt dạalai studentu ir jāstrādā, lai finansētu savas studijas. Tas noved pie izglìtības laika pagarināšanās, kā rezultātā reproduktīvā funkcija tiek vēl vairāk novēlota. Izglìitiba ietekmē dzimstību arī ārpus dzìves cikla notikumu laika-izglìtỉbas līmenis izmaina indivìda prioritātes un vēlmes gan attiecībā uz partnerattiecību veidošanu, gan arì bērnu radīšanu. Sievietēm ar augstāku izglìtību vēlamais un ìstenotais bērnu skaits ir mazāks kā sievietēm ar zemāku izglìitibu. Tomēr pēdējos gados, piemēram, Skandināvijas valstīs, vērojama U-formas dzimstības lỉkne - vismazāk bērnu ir sievietēm ar vidējo izglìīibu, vairāk ar pamatizglìtību, bet arī ar augstāko izglìtības līmeni. Ir dokumentēts fakts, ka sievietēm ar augstāko izglìtỉbu ir «izdevigāk» dibināt ğimeni un dzemdēt bērnus vēlāk (ACS, 2010) - viṇām būs augstāki ienākumi un mazāka škiršanās iespējamība.

Sieviešu nodarbinātībai ir divējāda ietekme uz reproduktīvo izturēšanos. No vienas puses, ja sieviete nestrādā, alternatīvās izmaksas ir zemas, kas stimulē plānot bērna piedzimšanu. No otras puses, nestrādājošas sievietes ǵimenes ienākumi var būt pārāk nelieli, un tas mudina sievieti vai nu atrast darbu, lai papildinātu ienākumus, vai meklēt iespēju pašrealizācijai darbā. Šādos bezdarba gadījumos sievietes var izvēlēties atlikt bērna dzemdēšanu, lïdz uzkrāts lielāks kapitāls vai ir nostabilizējusies karjera. Latvijā sieviešu līdzdalība darba tirgū ir augsta un ir lielāka varbūtība, ka sieviete strādās, nevis paliks mājās. No šì viedokḷa otrais efekts ir ticamāks.

SOCIĀLAIS KAPITĀLS Pārejas perioda dinamika apgrūtina un pasliktina valsts un citu saistìto institūciju spējas efektīvi nodrošināt palīdzību cilvēkiem, kam tā nepieciešama. Individi tad lielākā mērā palaujas uz papildu atbalstu, ko var sniegt radinieki, draugi, kaimini vai kolēĝi. Šis atbalsts ir sociālā tìklā balstīts sociālais kapitāls. Tas tiek definēts kā resursu pieejamība indivīda sociālajā vidē. Jo vairāk resursu iespējams piesaistīt, jo lielāks atbalsts un tādējādi labāka indivìda ekonomiskā situācija. Sociālais kapitāls ir bezmaksas - parasti tas tiek nodrošināts palīdzỉbas formā no apkārtējiem. Šì palīdzība var būt dažādās formās - naudas aizdevums, darbs, bērnu pieskatišana, informācijas nodrošināšana, loğistika, izmitināšana u.c.

Sociālais kapitāls ir cieši saistīts ar savstarpējo sadarbību un uzticēšanos. Kopumā sociālais kapitāls spēj atvieglot ekonomisko situāciju un samazināt nedrošību, bet tā ietekme izpaužas caur savstarpējām sociālām attiecībām nevis caur ekonomisku darbỉbu, tāpēc arī tā ietekme uz dzimstību ir grūti novērtējama. Problēma pastāv arī apstāklī, ka sociālo kapitālu ir salīdzinoši grūti izmērìt. Šo teorētisko specifikāciju vispirms izstrādājuš Filipovs un Školnikovs (Philipov \& Shkolnikov, 2001). Filipovs (Philipov, 2003) savā darbā apskata sociālā kapitāla ietekmi uz reproduktīvajiem nodomiem Bulgārijā un Krievijā. Savukārt Būlers un Fị̣ipovs (Buehler \& Philipov, 2005) sniedz precīzu teorētisku diskusiju. Sociālā kapitāla tēma reproduktīvo lēmumu pienemšanas pētijumos nav jauns temats. Teorētiskajā struktūrā, ko piedāvājis Šons ar kolēợiem (Schoen et al., 1997), sociālā kapitāla palielināšanās saistāma ar motivāciju klūt par vecākiem. Autori novērtējuši, ka bērnu radīšanas nolūki ASv bija izteiktāki tiem cilvēkiem, kas uzskatija, ka 
viņu sociālais kapitāls pēc bērnu dzimšanas pieaugs. Detalizētu teorētisku pamatojumu šim mehānismam sniedz Estouns (Astone et al., 1999). Vienlaicīgi reālais saṇemtais sociālā kapitāla atbalsts jeb tā izmantošana var nebūt liela, bet nozimigiga ir individa apzina, ka pieejams atbalsts, ja tāds būs nepieciešams. Ja vecāki jūtas drošāki par atbalstu, tie drīzāk vēlēsies radīt pēcnācējus, pat ja atbalsts netiek izmantots. Abi uzskati nav pretrunā, tie drīzāk viens otru papildina (Philipov, 2006).

IDEOLOC̣ISKAS PĀRMAIṆAS Saskaṇā ar otrās demogrāfiskās pārejas (Second Demographic Transition) teoriju ideoloğiskās pārmainas ir galvenais dzinējspēks, kas nosaka demogrāfiskās tendences visās attīstītajās valstīs. Šo teoriju 1986. gadā formulēja Rons Lestidžs un Dirks van de Ka, norādot uz pārmaiṇām sabiedrības seksuālajā un reproduktīvajā uzvedībā laika posmā jau kopš 1963. gada. Lai arì teorija tikusi kritizēta kā nepastāvīga tendence, ka tā nav «pāreja» klasiskā demogrāfiskā izpratnē, vai vispār kā neatbilstoša demogrāfijas disciplīnai, jo tā runā par vērtībām, šobrīd par tās ietekmi pētnieki ir vienojušies - Rietumu sabiedrībā ir notikušas fundamentālas vērtību sistēmas izmainas, kas ietekmējušas reproduktīvo uzvedību. Lestidžs un Sarkins (Lesthaeghe \& Surkyn, 2002) apraksta šìs izmainas vērtību sistēmā par labu postmodernām vērtībām ar trīs komponentiem: 1) uzsvars uz individuālu autonomiju, 2) institucionālas autoritātes un kontroles noraidīšana, 3) tādu vērtību pieaugums, kas saistìts ar pašrealizāciju un savas personỉbas prioritizēšanu (Philipov et al., 2005). Individualitāte, personiskās intereses un labsajūta kḷūst daudz svarīgākas par ǵimeni, un šis process kopā ar visām pārējām izmainām rada pārmainas procesā, kā tiek veidota ğimene.

Lìdz ar totalitāro režīmu sabrukumu šis vērtỉbas ienākušas arī CAE valstu sabiedrībās. Tās atspoguḷ arī pāreju uz modernu demokrātisku sabiedrību. Tādu postmoderno vērtību pieaugumu, kas orientētas uz sevi, papildina relatīvs ar ğimeni saistīto vērtību samazinājums. Šie jautājumi CAE valstu kontekstā tiek apspriesti, piemēram, Kotovksa un Jozvjaka (Kotowska \& Jozwiak, 2003) darbā (par Poliju) un ANO publikācijā (Lesthaeghe \& Surkyn, 2002) (CAE valstis, ieskaitot Baltiju). Lìdz ar to jaunās vērtības novedušas pie dzimstības samazināšanās un tās atlikšanas, kāda ir notikusi arī Rietumu valstīs, tikai CAE tas noticis daudz straujāk.

Vairākas no pazīmēm, kas tiek saistītas ar otro demogrāfisko pāreju, varēja novērot jau pēdējos Latvijas un citu republiku padomju okupācijas gados. Pirmkārt, salīdzinoši liela sieviešu autonomija - sieviešu nodarbinātỉba bija liela, un alga bija nozīmīga ǵimenes budžeta sastāvdala. Otra pazime ir sekularizācija, kas sākās jau 2o. gados un padomju periodā absolūti saskanēja ar valsts ideoloǵiju. Turpretī citi faktori kḷuva iespējami tikai pēc PSRS sabrukuma - normu un kontroles izaicināšana un pašrealizācija pēc neatkarības atjaunošanas kḷuva izplatītākas.
Tādējādi otrā demogrāfiskā pāreja Latvijā var izskaidrot lielu dalu pārmaiṇu reproduktīvajā uzvedībā, bet ne visas (Magun \& Rudnev, 2010, citēts pēc Isupova, 2015).

SOCIĀLĀ ANOMIJA Anomijas klātbūtnē lēmumu pienemšana klūst neskaidra un apgrūtināta. Tā lēmumu pieņemšanu fundamentālos jautājumos pārvērš no racionālas neracionālā un spontānā, arī automātiskā. Tā veicina, piemēram, arī izvēli par labu nereğistrētai kopdzīvei laulības vietā, jo pirmajā variantā tā vienkārši «notiek», nepieņemot striktu lēmumu, salïdzinājumā ar laulïbu, kas ir tišs, apzināts solis (Stanley et al., 2006). Tādējādi nereg̛istrēta kopdzive kḷust izplatītāka neskaidros vai pārejas laikos (Isupova, 2015). Saskanāa ar Ešvina (Ashvin, 2006) pētijumu tas bijis būtisks iemesls nereǵistrētas kopdzīves izplatībai gan sievietēm, gan vīriešiem Krievijā pēdējās divās desmitgadēs.

Var sagaidīt, ka šādā anomiskā situācijā arī tāds svarīgs dzīves notikums kā bērna piedzimšana tiks atlikts vai vispār netiks īstenots. Uzskatāma anomijas ietekmes pazime redzama jau Sroles (Srole, 1956) pieejā anomijas mērišanai-viens no jautājumiem precīzi attiecas uz reprodukciju: «Vai jūs piekrītat apgalvojumam: spriežot pēc tā, kāda izskatās nākotne, nav prātīgi šobrīd radīt bērnu?» (oriğinālā: «Do you agree with the statement: It is hardly fair to bring children into this world with the way things look for the future?»). Tātad jau pašos pamatos L. Sroles izstrādātā skala saista anomiju ar vēlmi (nevēlēšanos) radīt bērnus. Tomēr tas neizskaidro un neatbild, vai dzimstības samazināšanās, kas seko politiskām un sociālām transformācijām, nozìmē tikai îslaicīgu bērnu radīšanas atlikšanu vai pilnīgu atteikšanos - tie tikai skaidro, ka anomiskā sabiedrības stāvoklī cilvēki atturēsies no bērnu radišanas.

Var uzskatît, ka periodam, kas sākās 1990. gadā, raksturīga normu neesamìba jeb anomija. Sabiedrības pārmainas radīja fundamentālas transformācijas visā institucionālajā, politiskajā, ekonomiskajā, sociālajā un kultūras vidē. Totalitārā režima nomaina ar demokrātisku valsts modeli ienesa nepieciešamību mainìt institūcijas un pienemt jaunu likumdošanu, kuras ieviešana prasija vairākus gadus. Vienlaiciggi šì transformācija ietvēra arī pēkšṇu veco normu un vērtỉbu sabrukumu un jaunu rašanos. Bet jaunās vērtību sistēmas pienemšanai un stabilizācijai vajadzīgs laiks.

Ḷevina, Mārtinsone un Klince (2017) sniedz izsmeḷošu diskusiju par situāciju un attiecībām starp anomiju un vērtībām Baltijas valstu iedzìvotājiem. Arī citās CAE valstīs anomija tikusi analizēta vairākos pètijumos. Piemēram, Dženovs (Genov, 1998) pētījis anomijas ietekmi uz dzives kvalitāti Bulgārijā. Filipovs, Speders un Billari (Philipov, Speder, \& Billari, 2006) studējuš anomijas un sociālā kapitāla ietekmi uz dzimstību Bulgārijā un Rumānijā, aprēkinot, ka anomijas klātesamìba sabiedrỉbā samazina dzimstỉbu. Lìdzịgs 
pētijums veikts par Krieviju (Isupova, 2015) un Ukrainu (Perelli-Harris, 2008). Tomēr mehānisms, kādā veidā anomija ietekmē ar reproduktivitāti saistītus lēmumus, detalizēti nav pētîts, lai arī Filipovs (Philipov, 2003) rakstijis par tās nozimīibu CAE valstīs. Visi minētie pètījumi secina, ka anomija ir viens no faktoriem, kas ietekmē reproduktivvo uzvedỉbu, un dzimstỉbas samazināšanās būtu jāanalizē anomijas kontekstā.

GIMENES/DEMOGRĀFISKĀ POLITIKA Demogrāfiskā politika kā dzimstību ietekmējošs faktors šajā diskusijā ar nodomu apskatīts pēdējais, jo pētījumu rezultāti nesniedz viennozīmìgu atbildi, vai šim faktoram pašam par sevi vispār ir statistiski nozimìga ietekme uz dzimstību. Ar ğimenes vai demogrāfisko politiku var saprast visdažādāko valsts atbalstu bērniem dažādās formās - gan tieši finansiālu: piedzimšanas, vecāku, maternitātes u.tml. pabalstus, gan netieši: nodoklu atvieglojumus par apgādājamajiem un nekustamajiem ỉpašumiem, finansējumu bērnu pieskatī̌anai, bērnudārziem, gan arī nemateriālu atbalstu: papildu atvaḷinājumu, attieksmi, priekšroku dažāāās situācijās u.tml.

Katrā valstī ir izveidojusies atbalsta sistēma, kas satur vairākus šos elementus visdažādākajās kombinācijās un apjomos. Attiecīgā politika var būt mērḳtiecīgi un detalizēti izstrādāta vai arī veidojusies vēsturiski no elementiem, kas tur ilgi bijuši, un papildināta pēc dažādām iniciatīvām. Tā kā ǵimenes/demogrāfiskā politika ietver tik daudz elementu, tās ietekmi ir loti grūti izmērìt vai precīzi plānot. Piemēram, bērna kopšanas atvaḷinājuma ilgumam, domājams, ir pozitīva ietekme uz vēlmi radīt bērnus, un šāds apsvērums ir loğisks un likumsakarīgs. Bet ir grūti izmērāms, tieši cik lielā mērā, ja vispār, tas ietekmē reproduktīvo uzvedību katrā sociālā vai ekonomiskā situācijā.

Latvijas kontekstā ir veikti pētỉjumi un analizētas demogrāfiskās politikas (skat., piemēram, Ābolina, 2016). Visbiežāk šie apskati atrod korelāciju starp pabalstu lielumu un dzimstību Latvijā, taču tie neapskata cēloṇseku principu un citus saistītos ietekmes faktorus, piemēram, ekonomikas attīstību; tādējādi cēlonība netiek pierādìta. Šo novērojumu pastiprina dati salīdzinošā kontekstā - neskatoties uz biežu kritiku, Latvijā atbalstu ğimenēm var uzskatìt par dāsnu. Ģimenes pabalsti nav augsti, un Latvijā ǵgimenēm ar bērniem atbalstam tiek atvēlēti 1,2 \% no IKP (skat. Eurostat datubāzi), bet Igaunijai, piemēram, šis rādītājs ir 2,5\%, Rietumeiropas valstīm - vidēji 1,7\% no IKP. Vienlaicīgi Latvijā ir vieni no garākajiem apmaksātajiem vecāku atvalịnājumiem Eiropā, nemaz nerunājot par pasauli-ja vērtē apmaksāto bērnu kopšanas atvalinājumu pilna laika ekvivalentos, kas pieejams mātei (atvalinājuma garums, kas būtu nosegts, ja maksātu $100 \%$ no personas vidējiem ienākumiem), Latvijā tas ir 53 nedēḷas (Igaunijā-85, Lietuvā-62, ASV - o, Lielbritānijā-12, Šveicē -8 , İrijā -9 nedēlas). Starp atbalstu finansiālā izteiksmē, nemateriālā izteiksmē vai atvalinājuma garumu, no vienas puses, un dzimstību, no otras puses, nepastāv korelācija. Tātad apgalvojumam - lielāks pabalsts palielinās dzimstỉbu Latvijā - nav pamata. Tam nav pierādỉjumu arī pētijjumos par demogrāfiju, kur pabalstu paaugstināšana parāda tikai marginālu ne-negatîvu ietekmi uz dzimstības rādìtājiem. Kopumā jāsecina, ka pieejamie politikas instrumenti dzimstības ietekmēšanai ir neefektīvi.

\section{Secinājum}

Loti zemā dzimstība Latvijā pārejas periodā (apmēram 1990.-2000. gads) (summārais dzimstības koeficients 1,1-1,3), kas turpinājās ekonomikas stabilizācijas gados (no 2000. gada) (summārais dzimstības koeficients 1,8 2016. gadā) un joprojām nesasniedz nosacìto tautas atražošanās koeficientu $(2,1)$, ir komplekss process un tam nav viena unikāla izskaidrojuma. Sociālās un ekonomiskās pārmaiṇas ir mainījušas reproduktīvo lēmumu pienemš̌anu, bet jaunie paradumi joprojām nav labi izpētīti.

Demogrāfiskā literatūra piedāvā trīs svarīgākos teorētiskos izskaidrojumus, kāpēc CAE valstīs, tai skaitā Latvijā, kopš neatkarības atjaunošanas samazinājusies dzimstība, tie ir - ekonomiskā nedrošība, otrā demogrāfiskā pāreja un sabiedrības anomija. Tomēr visiem šiem skaidrojumiem trūkst mikrolīmeṇa empīisku pierādījumu pētijjumos. Nevienā no apskatìtajiem pētījumiem, piemēram, nav konstatēta tieša saistỉba starp indivīda bērnu skaitu un tā ekonomisko stāvokli, bezdarbu vai ienākumiem. Tāpat maz pētìta ir sakarība starp vērtību sistēmas izmaiņām un dzimstību. Vēl mazāk demogrāfiskajos empīriskajos pētijumos ietverta anomija, kas savukārt no teorijas viedokla parādās kā nozīmīgs faktors. Tādēl to nepieciešams pētìt. Lai labāk izprastu likumsakarības, nepieciešama detalizēta pieeja un mikrolimeņa modelēšana, kas iekḷautu visus iepriekš apskatītos faktorus, ta skaitā anomiju, kā arī visu faktoru savstarpējo ietekmi, jo atseviškiem faktoriem ir pierādīta mīkstinoša ietekme uz individuālo anomiju. Piemēram, Perelli-Hariss (Perelli-Harris, 2006) norāda, ka individuālās anomijas stāvokl pēcpadomju Krievijā samazināja labklājības līmenis un neoficiālā nodarbinātība, kas kopumā atstāja pozitīvu iespaidu uz dzimstību. Savukārt citi faktori-stress, alkoholisms, sliktas partnerattiecības - anomijas atstāto negativo iespaidu uz reprodukciju tikai pastiprina. Saistiba starp mirstibas un saslimstības pieaugumu un dzimstības samazināšanos prasa papildu pētỉjumus, jo ir iespējams, ka abas ietekmes rodas no vienas un tās pašas destruktīvās uzvedỉbas un galu galā no sociālās anomijas.

Visbeidzot, ǵimenes politika var ietekmēt reproduktīvo lēmumu pieñemšanu, tomēr politikas ietekmes apjoms un ietekmes mehānismi ir ḷoti kompleksi un tiem nebūs rezultātu, ja netiks pievērsta uzmanība un novērsts galvenais cēlonis, kas saskaṇā ar iepriekš analizētajiem pētỉjumiem varētu būt anomija. 


\section{Anomija Latvijas svētku un pieminas dienu kalendārā un praksē}

Izmantojot Emila Dirkema anomijas koncepciju, nodalāa sniegts Latvijas svētku, atceres un atzīmējamo dienu valsts kalendāra, svētku svinēšanas un komemorativo prakšu iztirzājums. Tas ir balstìts uz LU Sociālo zinātṇu fakultātes Sociālo un politisko pètījumu institūta pasūtìto socioloğisko aptauju rezultātu un svētku un pieminas dienu rituālu analīzi. Aplūkotas četras svētku, atceres un atzīmējamo dienu grupas: 1) valsts un patriotiskie svētki, 2) komunistiskā un nacistiskā totalitārā režima upuru pieminas dienas, 3) no padomju režīma mantotie svētki, 4) spriedzes menedžmenta svētki. Secināts, ka atsevišķās Latvijas svētku, atceres un atzimējamo dienu kultūras jomās ir vērojama anomija, kas vēsta par pretrunām starp pastāvošo dzīveskārtību un sociālo grupu un individu identitātēm un vērtỉbām.

Mūsdienu Latvijas svētku un pieminas dienu kalendāra un prakses sākotne meklējama 20.gs. 80. gadu otrajā pusē - Trešãs atmodas laikā kad anomijas situācija bija izveidojusies lielas sabiedrības dalas attiecībās ar tolaik reāli funkcionējošo Padomju Savienības svētku dienu kalendāru. Sociologa Emīla Dirkema piedāvātais anomijas koncepts izmantojams, lai raksturotu sabiedrībā pastāvošu denotatīvu strukturālu pretrunu, kad publiski proponētās pamatvērtvērtības un normas neatbilst reāli funkcionējošai sociālajai situācijai. Šì neatbilstība lielā dạā sabiedrības rada atsvešinātību no valdošās sociālās kārtības, pieškir tās eksistencei bezjēdzīgumu, kā arī rada identitātes krìzi. Anomijas situāciju parasti atrisina pārmaiņas, kurās top sociālajai realitātei atbilstīgas jaunas identitātes, vērtỉbu sistēmas un normas. Šis process mazina un/vai novērš pastāvošās dzīveskārtības, sabiedrības un indivìdu pretrunas un rada nozīmi vinu esībai (Greenfeld, 2006, p. 212).

Svētku svinēšana un piemiṇas dienu atzīmēšanas pētniecība balstās uz citu E. Dirkema pieeju, kas svētkus un rituālus aplūko kā svarīgu sociālās kārtības dalı, ar kuras starpniecību sociālās grupas periodiski no jauna apliecina, apstiprina savu esību un stiprina sabiedrības solidaritāti. Viňš uzsver, ka «nav tādas sabiedrïbas, kas nejustu nepieciešamïbu ik pēc regulāra intervāla apliecināt un atkal no jauna apstiprināt kolektīvos uzskatus un kolektīvās idejas, kas veido tās vienotību un tās individualitāti» (Durkheim, 2001, p. 322). Svētki un rituāli ir ne tikai prakšu, bet arī ideju sistēma, kas atspogulo pastāvošo pasauli. Svētki apstādina ikdienu un uz laiku pārtrauc tās rutīnu. Tajos klātienē un neklātienē pulcējas ḷaudis, la kopā svinētu savas saiknes, attiecības, ideālus un morālos principus, baudītu pašreizējo sociālo kārtību un ar savstarpējās solidaritātes apliecinājumu pieškirtu tai jaunu spēku un likumību. Parasti rituāli vienlaikus gan atspoguḷo, gan veido realitātes definējumu un vērtējumu, kā arī to dalībnieku vidū rada emocionālas saites ar pozitivām jūtām, savilnojumu un sentimentu (Rothenbuhler, 1998, pp. 41-42). Rituāli un svētki allaž ieklaujas 
konkrētā telpā un laikā. Tie tiek pastāvīgi «izgudroti» un atkal no jauna «re-izgudroti», lai nodrošinātu sociālo kohēziju, iedibinātu un leǵitimētu varas institūcijas, autoritātes, nostiprinātu sociālo kārtỉbu, kā arī veiktu vērtību sistēmas un uzvedỉbas konvencijas audzināšanu (Hobsbawm, 1983, p. 9). Rituāliem piemìt dinamiskums. Transformējoties sabiedrībai, mainās arī tie. Vieni tiek noliegti, refraktē, izirst, nonāk aizmirstībā, to vietā nāk citi. Svētki un rituāli ne tikai vieno cilvēkus, bet bieži ir arī daudzu konfliktu iemesls un atspulgs. Turklāt arī pašu konfliktu ietvaros tiek radíti un istenoti rituāli (Kertzer, 1988, pp. 62-63; Grimes, 2011, pp. 22-24).

Šìs nodaḷas uzdevums ir, izmantojot anomijas koncepciju, vērtēt Latvijas svētku un atceres dienu kalendāra un to atzimēěsanas prakses galvenos aspektus. Pētijjumā izmantoti LU Sociālo zinātṇu fakultātes Sociālo un politisko pētijuma institūta valsts pētijumu programmas «Nacionālā identitāte» projekta «Latvijas sociālā atmiṇa un identitāte» (2010-2014) un SUSTINNO projekta «Sabiedrības vērtīborientācijas un sabiedrības atjaunošanās» (2014-2018) pasūtīto socioloğisko aptauju dati. Aptauju anketas izstrādātas un papildinātas šo projektu ietvaros.

\section{Latvijas svētku un} piemiṇas dienu kalendārs

Latvijas svētku un piemiņas dienu kalendārs sāka veidoties Trešās atmodas laikā 20. gadsimta 8o.gadu otrajā pusē. Vispirms tas tapa realitātē-protestu praksēe, kad Padomju Savienībā istenotās pārbūves atklātỉbas kurss publiskajā telpā iniciēja stalininisko noziegumu atmaskojumu un nosodījumu. Arī Latvijas PSR sabiedrības dzives un mediju dienaskārtỉbā nonāca jautājums par padomju varas īstenotajām masu izsūtīšanām un represijām pēc šĩs zemes okupācijas un valstiskuma likvidācijas (Smith, 1996; Sherlock, 2007; Aron, 2012). Pirmais deportāciju upuriem veltītais piemiṇas pasākums - grupas «Helsinki 86» rīkotā ziedu nolikšana pie Brīvibas pieminekḷa - notika 1987. gada 14. jūnijā, neraugoties uz varas iestāžu pretestību un šā pasākuma nomelnošanas kampaṇu plašsazinnas līdzekḷos. Šim notikumam sekoja nākamie. Tajos ne tikai tika pieminēti stạlinisma upuri un nosodìti tā noziegumi, bet arī tika pausts protests pret Padomju Savienības istenoto Baltijas valstu okupāciju, padomju režīmu un tā politiku Latvijā. Izmantojot milicijas un Valsts drošibas komitejas spēkus, varas iestādes centās nepieḷaut lielu cilvēku masu pieplūdumu un kavēja atceres dienu norises, tādējādi radot konflikta situācijas. Brīvibas pieminekḷ apkaimi apjoza miliču kēdes, potenciālos pasākuma organizatorus un dalïbniekus apcietināja vai turēja mājas arestā, tika izsacīi draudi, pausts nosodījums plašsaziņas līdzekḷos. Lỉdzịgi varas iestādes reaǵēja arī uz nākamajiem padomju režìmu nosodošajiem publiskajiem masu pasākumiem. Tomēr jau 1988. gada 25. martā tika atlauta radošo savienību organizētā ziedu nolikšana
Brālu kapos, pieminot masu deportāciju upurus, lai gan todien vienlaikus milicija un citu drošỉbas struktūru vienības kavēja ziedu nolikšanu pie Brīvibas pieminekḷa. Šie notikumi ir iemantojuši nosaukumu «kalendāru nemierì, kas patapināts no 16. gadsimtā Rīgā notikušajiem protestiem pret Gregora kalendāru (Zïle, 1998, 94.-121.lpp.; Blūzma, 2008, 290.-292.lpp.; Vārpa, 2012 124.-138.lpp.)

20. gs. 8o.gadu otrajā pusē juridiski spēkā bija Padomju Savienībā funkcionējošais kalendārs, kura pamati veidoti stalinisma periodā 20 . gs. 30. gados un kurā iekḷauto svētku svinēšana bija būtiska valsts pārvaldes sastāvdaḷa, iedzīvotāju lojalitātes kontroles instruments un varas leǵitimitātes publiskā demonstrācija (skat. Lane, 1981; Gill, 2011; Rolf, 2013). Padomju Savienībā svētku organizēšana un svinēšana bija labi institucionalizēta, menedžèta, finansēta un kontrolēta. Tiem tika nodrošināts visplašākais mediju atbalsts. Preses, televīzijas un radio dienaskārtība bija pilnībā paklauta valsts galvenajiem svētkiem. Šì sistēma darbojās arī Latvijas PSR. Svētku ideoloğiskā pārraudzība atradās Latvijas Komunistiskās partijas Centrālās komitejas pārziṇā, bet praktiskā un metodiskā vadība - Kultūras ministrijas un tās paklautībā esošā Tautas mākslas centra zināā. Visās rūpnīcās, kolhozos, skolās, iestādēs un citās institūcijās bija par svētku noris un cilvēku iesaisti atbildīgas personas, svētku scenāriju un noformējumu veidoja un svētkos iekḷautajos mākslinieciskajos priekšnesumos piedalijjās augsta līmena profesionāli (Uzule \& Zelče, 2014, 123.-125.lpp.).

Latvijā valsts nozīmes svētku dienu kalendāra transformāciju aizsāka 1988. gada 15. aprīlī ar Latvijas PSR Augstākās padomes Prezidija pienemt lēmumu par Līgo svētku svinēšanu un 24. jūnija noteikšanu par atstrādājamu brīvdienu. 1989. gada 10. novembrī Latvijas PSR Augstākā padome pieṇēma «Latvijas Padomju Sociālistiskās Republikas likumu par svētku un atceres dienām», kurā bija ieklautas trīs jaunas svētku brīvdienas - Vasaras saulgrieži jeb Līgo diena 24. jūnijā, Ziemassvētki 25. decembrī un Latvijas Republikas proklamēšanas diena 18. novembrī. Vienlaikus šis likums saglabāja arī visas Padomju Savienības svētku brīvdienas. 1988. un 1989. gadā Latvijā tika atzīmēti visi padomju svētki, notika jau gadu desmitiem ierastās darbaḷaužu demonstrācijas. Šì laika valsts svētku un rituālu prakse raksturojama kā anomija. No vienas puses, jau ar lielu idejisko un morālo pārliecību tika atzìmēta padomju režìma upuru piemina un nosodīti noziegumi, bet, no otras puses, joprojām tika kultivēti padomju režìmu cildinošie rituāli, piemēram, Rīgā Komjaunatnes krastmalā (tagad-11. novembra krastmalā) notika Lielajai Oktobra sociālistiskajai revolūcijai un darbalaužu solidaritātei veltītas demonstrācijas, tika svinēta Padomju Latvijas dibināšanas gadadiena. Nereti vieni un tie paši cilvēki piedalijās jēgas, satura un vērtību ziṇā pretējos pasākumos (skat. Gailišs, 1988, 1.lpp.; Gefters u.c., 1988, 1.-3.lpp.; Gefters u. c., 1989, 1.-2.lpp.). 
Anomijas situāciju likumdošanas un prakses pamatlimenì atrisināja 1990. gada 3. oktobrī Latvijas Republikas Augstākās padomes pieṇemtais likums «Par svētku, atceres un atzīmējamām dienām». Tajā vairs nebija padomju svētku dienu. Svētku brīvdienas tika paredzētas Ziemassvētkos, Lieldienās, Lỉgo dienā, 31. decembrī un 1.janvārī, kā arī 18. novembrì. Komemoratîvo dienu statuss tika piešķirts 25. martam - Komunistiskā terora upuru piemiņas dienai, 4. maijam - Latvijas Republikas Neatkarības deklarācijas pasludināšanas dienai, 9. maijam - Otrā pasaules kara upuru piemiṇas dienai, 14. jūnijam - Komunistiskā terora upuru piemiṇas dienai, 4. jūlijamEbreju tautas genocĩda piemiņas dienai un 11. novembrim - Lāčplēša dienai (Augstākā Padome, 1990).

Latvijas svētku un atceres dienu likumā ir veikti vairāki grozijjumi. 1995. gada 6. aprịla grozijumi paredzēja, ka no komemorativo dienu saraksta izslēgts 9. maijs, savukārt 8. maijs tika pasludināts par «Nacisma sagrāves dienu un Otrā pasaules kara upuru pieminas dienu». Ar šo lēmumu Latvija formāli ieḳ̣āvās Eiropas Otrā pasaules kara piemiṇas telpā. Nākamajos gados veiktie likuma grozijumi atceres un atzīmējamo dienu sarakstu bagātināja ar daudziem jauniem datumiem. 1995. gadā tajā tika ieklautas Latvijas valsts politiskajā un militārajā vēsturē svarīgu notikumu pieminas dienas, piemēram, 26. janvāris - Latvijas Republikas starptautiskās (de iure) atzī̌̌anas diena, 22.jūnijs - Varonu pieminas diena (Cēsu kaujas atceres diena) un 11. augusts - Latvijas brīivibas cinitāju piemiṇas diena. Saeimas 1998. gada 17. jūnijā pieṇemtais lēmums valsts atceres dienu kalendārā ietvēra 16. martu - Latviešu karavīru atceres dienu. Jau 200o. gada 17. februārī Saeima 16. martu izslēdza no atceres dienu kalendāra, jo latviešu leǵionāriem - karavīiem, kuri Otrajā pasaules karā karoja nacistiskās Vācijas pusē, - veltìtas komemoratīvas dienas atrašanos valsts atzìtu atceres dienu sarakstā nosodỉja vairākas ietekmīgas starptautiskās un vietējās organizācijas un tās oficiāla atzīmēšana bija pretrunā Eiropas vēstures politikai. Tika papildināts arī padomju totalitārā režīma veikto noziegumu atceres un to upuru pieminas dienu saraksts. 1998. gadā pēc Austrumu Latviešu biedrïbas iniciatīvas decembra pirmā svētdiena ieguva pret latviešu tautu vērstā totalitārā komunistiskā režìma genocìda upuru piemiṇas dienas statusu, kad tika pieminēti Padomju Savienībā staliiniskajās represijās 1937.-1938. gadā nogalinātie. 2000. gadā pienemtie grozijumi paredzēja 17.jūnija - Latvijas Republikas okupācijas dienas - atceri, 2009. gada likuma labojumi 23. augustu pasludināja par stalịinisma un nacisma upuru atceres dienu. 20. gs. beigās aizsākās Latvijas nesenās vēstures notikumiem - Trešajai atmodai un valstiskuma atjaunošanai - veltìto dienu fiksācija likumā «Par svētku, atceres un atzīmējamām dienām». 1997. un 2002. gadā pieṇemtie grozījumi atceres un atzīmējamo dienu klāstā ieklâava 20. janvāri-1991. gada barikāžu aizstāvju atceres dienu un 21. augustu - konstitucionālā likuma «Par Latvijas Republikas valstisko statusu» pienemšanas un Latvijas Republikas faktiskās neatkarības atjaunošanas dienu. Savukārt 4. maijs - Latvijas Republikas Neatkarības deklarācijas pasludināšanas diena - kḷuva par valsts svētkiem un brīvdienu.

21. gadsimta pirmās desmitgades otrajā pusē risinājās rosigga gímenei un profesijām veltìtu atzīmējamo dienu iekḷaušana atceres un atzīmējamo dienu sarakstā. Tāpat tajā tika integrētas arī starptautiski svinētas dienas. 2018. gada sākumā spēkā esošais likums «Par svētku, atceres un atzīmējamām dienām» paredz, ka Latvijā ir 12 svētku dienas (dažas no tām atzīmējamas vairākas dienas) un 27 atceres un atzimējamās dienas (Augstākā Padome, 1990; Skangale, 2008). Tomēr tajā fiksētais svētku un piemiṇas dienu kalendārs nekādā ziṇā nav uzskatāms par konstantu. Visai bieži izskan piedāvājumi to papildināt. Piemēram, 2018. gada 15. martā Saeimas atbalstu guva priekšlikums svētku dienas statusu piešḳirt Lāčplēša dienai, pamatojot, ka 11. novembris kā oficiāla brīvdiena «būtu cieṇpilns žests un saliedējoša iniciativva gan Latvijas simtgadē, gan sagaidot Bermontiādes simtgadi» (Žukova, 2018b), bet tika noraidīti Nacionālās apvienības «Visu Latvijai!»—«Tēvzemei un Brīvỉbai/LNNK» jau vairākas reizes piedāvātie grozỉjumi par atceres un atzīmējamās dienas statusa pieškiršanu 16. martam (Žukova, 2018a). Savukārt 20. martā valdība atbalstīja Satiksmes ministrijas un Aizsardzibas ministrijas ierosmi veikt grozijumus likumā «Par svētku, atceres un atzīmējamām dienām» un tajā iekḷaut Aviācijas darbinieku dienu 6.jūlijā, Autotransporta darbinieku dienu septembra trešajā svētdienā un Latvijas karaviru dienu 10. jūlijā (Žukova, 2018c).

Reālā svētku svinēšanas prakse pilnībā nesakrīt ar likumā «Par svētku, atceres un atzimējamām dienām» fiksēto valsts svētku kalendāru. Piemēram, jau ilgsstoši nacionālā mērogā tiek atzīmēta Latviešu leǵionāru pieminas diena 16. martā un Padomju Savienības uzvara Lielajā Tēvijas karā 9. maijā. Šì situācija liecina par anomiju Latvijas sabiedrībā, jo valsts un tās institūciju piedāvātās pamatvērtības un normas acìm redzami nav pienemamas noteiktai sabiedrības dalai, kas veido savu atzīmējamo dienu kalendāru.

Jāatgādina, ka Latvijas svētku, atceres un atzīmējamo dienu kalendārs tapa pārejas laikā uz demokrātisku un neatkarīgu valsti, kā arī pēcpadomju valsts un sabiedrības esības formā, kas tā saturā un vērtỉbās radijijis būtisku nospiedumu. Vēsturiskā un vispārcilvēciskā taisnīguma atjaunošana bija galvenais daudzo totalitārisma upuru piemiṇas un nosodijuma dienu iekḷaušanas kalendārā iemesls. Nākamo svētku, atceres un atzīmējamo dienu kalendāra veidošanas ietvaru radīja Latvijas tapšana par salīdzinoši labklājīgu, uz patērnieciskām vērtībām orientētu rietumniecisku valsti. Tas nozīmēja nepieciešamību pēc priecigi un jautri svinamiem svētkiem, kas raisa pozitīvas emocijas. Dažādiem svētkiem ir atškirīgas lomas sabiedrībā, tomēr to pamatuzdevums ir socializācija, sabiedrības integrācija, kopīgu vērtību akceptēšana. Dalā svētku tajos iemiesotais naratīvs un rituāli tiešā veidā stiprina solidaritāti, savukārt citos svētkos šis uzdevums tiek veikts netiešā 
vai pastarpinātā veidā, nodrošinot ikdienā uzkrātās spriedzes mazināšanos, atbrīvošanos no tās, atpūtu. Šos svētkus arī dēvē par «spriedzes menedžmenta svētkiem». Tādi ir visās sabiedrībās un to kalendāros, piemēram, Vecgada/Jaungada vakars, Mardi Gras (Treknā otrdiena), Purims, Oktoberfests (Oktobra svētki). Tiem piemìt indulgences daba, sabiedribu vieno uzvedỉba, kas citās dzīves situācijās tiktu atzìta par asociālu, dīvainu un nepieņemamu. Šie svētki ačgārni nostiprina sabiedrības vienotību, pārliecību un mazina distanci starp svešiniekiem. Vienlaikus ne visi svētki un ne vienmēr pilda sabiedrības vienošanas lomu. Rituāli, kā arī tajos ietverto vērtību atzīšana šḳel sabiedrību, veido robežas un sekmē konfrontāciju starp tās grupām (Etzioni, 2001, pp.118-122). Latvijas svētku praksē ir gan sabiedrïbas solidaritāti formējošie, gan to ārdošie rituāli, kā arī gan anomijas situācijas veidojošie, gan risinošie svētki un atceres dienas. Turklāt svinēšana ir dažādojusies un diferencējusies sociālo grupu, paaudžu un reğionu līmenī.

\section{Svētku prakses}

Jauno svētku un to svinēšanas rituālu iedzīvināšana vērtējama kā visai sarežğîits process. Padomju Savienības pastāvēšanas beigu gados un atjaunotās valsts pastāvēšanas pirmajos gados svētku svinēšana balstijjās uz sabiedrības dalas entuziasmu un sajūsmu par padomju okupācijas beigām, taču jau 2o.gs. 90. gadu vidū aizrautība bija noplakusi. Dzìves līmeṇa kritums, sociālā nestabilitāte, materiālās problēmas, inflācija, kriminalitātes pieaugums ekonomiskās un politiskās sistēmas transformācijas un turbulences dạ̣ā sabiedrības radīja vilšanos un pasivitāti. Šìs norises arī lielā dalā sabiedrības radijja valstiskās un nacionālās identitātes problēmas (Zepa \& Kḷave, 2011), kas atspoguḷojās arī valsts svētku svinēšanas praksēs. 20.gs. 90.gadu un tūkstošgades sākuma svētku svinēšanas kultūra ir visai maz izzināta. Ir dati par situāciju 21. gss. pirmās desmitgades vidū un otrajā pusē. Piemēram, 2005. gadā gandriz divas trešdalıas aptaujāto atzina, ka nesvin Lāčplēša dienu, un ap $40 \%$ aptaujāto atzina, ka vinniem Latvijas proklamēšanas diena 18 . novembris ir parasta brīvdiena un vini šos svētkus îpaši nesvin. Arī nākamajā gadā situācija bija visai līdzịga (Kantar TNS, 2005a, 2005b, 2006a, 2006b). Vienlaikus aptaujas liecināja, ka Latvijas iedzivotāji labprāt svin t. s. spriedzes mazināšanas svētkus. 95-96\% no aptaujātajiem atzina, ka atzīmē Ziemassvētkus, Jānus un Lìgo svētkus, un $88 \%$ norādija, ka viniiem svētku diena ir arī 8. marts (Kantar TNS, 2006c, 2006d, 2006e).

Nozīmīgs ir Baltijas Sociālo zinātṇu institūta 2007. gadā veiktais socioloğiskais pētijjums par Latvijas oficiālajiem svētkiem, kas atklāja neiepriecinošu ainu gan to organizēšanas, gan svinēšanas, gan to jēgas izpratnes ziņā. Tika konstatēts, ka pat svētku organizatoriem ir problēmas ar valsts nozīmes pasākumu mērku formulēšanu. Pētijums liecināja, ka Latvijas sabiedrībā pastāv atškirīigas izpratnes par valstij svarīgiem vēstures notikumiem un ka nav izveidoti visus valsts iedzivotājus vienojoši valsts svētku vēstijjumi, kas kalpotu par Latvijas Republikas izveidošanas un šā notikuma nozìmes naratīvu (at)ražošanas un uzturēěanas instrumentu un konkrētajiem valsts svētkiem pieškirtu individuālu seju. Savukārt iedzīvotāji no svētkiem gaidīja ne tikai emocionāli piesātinātu solidaritātes un patriotisma jūtu uzbangojumu, bet arī iespēju izklaidēties un atpūsties (Zepa, 2008). Šajā situācijā ir vērojamas spilgtas anomijas pazīmes, kas raksturoja tālaika valstiskās identitātes krìzes situāciju.

2007. gada pētijuma atziṇas tika ṇemtas vērā, veidojot turpmāko Latvijas svētku politiku, piešķirot tai mērḳtiecigumu, izdalot finansējumu, radot to idejiskās un organizatoriskās koncepcijas. Šì politika rezultējās Latvijas Republikas 9o. gadadienas svinībās, kuras koordinēja Aizsardzības ministrija un kuras organizatoriskās rīcības komisijas sastāvu veidoja nozimmīgas valsts amatpersonas. Valsts svētkiem bija vienojoša patriotiska devize «Iededzies par Latviju!», logotips, videoklipi, suvenīri, mājaslapa www.lvgo.lv, mediju atbalsts. Valsts 9o.gadadienas svinībām tika piešḳirti 1,95 miljoni latu, to pasākumu kalendārs sākās maijā un noslēdzās îsi pirms Ziemassvētkiem. Programmas nozīmigaākās sastāvdalas veidoja bērniem adresētie pasākumi, akcija «Gaismas tilti», Lielā talka, skrējiens «Skrien par Latviju», Klubu nakts «Atver svētkus!», filmas «Vienīgā fotogrāfija» izrādes. Tajā bija arī neiztrūkstošie oficiālie rituāli ar valsts augstāko amatpersonu, ārvalstu viesu un diplomātu piedalīšanos - ekumeniskais dievkalpojums Doma baznīcā, ziedu nolikšana pie Brīvibas pieminekḷa, Valsts prezidenta runa, svinigais koncerts Nacionālajā teātrī, svētku salūts (www.lvgo.lv; Vose, 2009). 2008. gada novembra sākumā veiktā iedzīvotāju socioloğiskā aptauja vēstỉja, ka $46 \%$ respondentu Latvijas valsts proklamēšanas svētkus atzina par nozimīgiem un vienmēr vai gandrìz vienmēr svinēja, $34 \%$ - par maznozīmīgiem, ko dažreiz atzìmēja, $13 \%$ - par nepavisam ne nozimingiem un nesvinamiem, bet $7 \%$ aptaujāto nebija viedokḷa. Aptaujas dati liecināja, ka Latvijas iedzīvotāiji visbiežāk 18. novembri atzimēe, klātienē apmeklējot svētku pasākumus (56\%) vai vērojot tiem veltìtos raidỉjumus televizijā (35\%). Aptaujā arì tika konstatēts, ka salīdzinoši biežāk Latvijas valsts dibināšanas svētkus nesvin iedzīvotāji vecumā no 21 līdz 30 gadiem, cittautieši, nepilsoṇi, cilvēki ar sākumskolas, pamata vai vidējo speciālo izglìiību, kā arī iedzīvotāji, kuri dzīvo vieni paši (Kantar TNS, 2008). Kopumā valsts 90. gadadienas svinības, to intensitāte un klātesamība Latvijas pilsētvidēs, kultūrā, skolās un medijos, kā arī rituālu daudzveidība lauj šos svētkus vērtēt kā nozīmīgu valstiskās identitātes un piederības veidotāju, kas būtiski mazināja anomiju un iezimêjja jaunu pavērsienu valsts svētku svinēšanas politikā un praksē. Svētkus vienojošs elements bija arī tā logotipa ar pieaugoša salūta motīvu plašā, daudzveidī gā lietošana, ko reglamentēja arī noteikumi. Vienlaikus jāteic, ka 21. gadsimta pirmās desmitgades beigās svētku svinēšanas ainā vērojamas arī jaunas 
anomijas situācijas, ko radīja atškịirịās identitātes un pagātnes interpretācijā balstītās Otrā pasaules kara piemiṇas dienu atzīmēšanas prakses.

Nodạalas turpinājumā sniegts pārskats par Latvijas nozīmīgāko svētku, atceres un atzīmējamo dienu svinēšanu 21.gs. otrajā desmitgadē, tos iedalot četrās grupās: 1) valsts un patriotiskie svētki, 2) komunistiskā un nacistiskā totalitārā režima upuru piemiņas dienas, 3) no padomju režìma mantotie svētki, 4) spriedzes menedžmenta svētki. Galvenā uzmanība veltita pirmajām trim svētku grupām.

\section{Valsts un patriotiskie svētki}

Latvijas nozīmīgākie valsts un patriotiskie svētki ir veltīti Latvijas valsts dzimšanas dienai, Brīivibas cīnām (1918-1920), valstiskuma veidošanai un neatkarïbas atjaunošanai. Šiem notikumiem valsts svētku kalendārā veltìti devini svētki, no tiem brīvdiena ir paredzēta četros - Latvijas Republikas pasludināšanas dienā 18. novembrī, Satversmes sapulces sasaukšanas dienā 1. maijā un Neatkarības deklarācijas pieṇemšanas dienā 4. maijā, kopš 2018. gadaLāčplēša dienā 11. novembrī.

Valsts galvenie svētki ir LATVIJAS REPUBLIKAS PASLUDINĀŠANAS DIENA 18. NOVEMBRī. To svinēšanu nākas salāgot ar dabas apstākḷiem-vēso laiku, nereti ar lietu vai sniegu, îso dienu. Aptauju dati liecina, ka valsts uzsāktā šo svētku menedžěšana un ieguldītās finanses nes rezultātus. Pieaug aktīvo svinētāju skaits - 2016. gadā svētkus atzìmēja jau trīs ceturtdaḷas valsts iedzìvotāju -, palielinās interese par piedāvātajiem publiskajiem pasākumiem, it ipaši līdzdalības pasākumiem, piemēram, ikgadējo (kopš 20o8. gada) gaismas festivālu «Staro Rīga», lāpu gājienu, kopīgo valsts himnas dziedāšanu, svētku salūtu. Savas svētku programmas tiek veidotas arī reğionos. Būtiska loma ir sabiedriskajiem medijiem, kas piedāvā svarīoāko notikumu translācijas, Latvijas filmu izrādes, populārās mūzikas koncertus. Svētkiem veltiti raidījumi tiek ieklauti arī komercmediju programmās.

Socioloğisko aptauju datu analīze vēsta, ka svētku atzīmēšanā kopumā piedalās visas sociālās, etniskās, profesiju un vecuma grupas. Tomēr šajā nozīmīgajā rituālā ir vairāki lỉdzdalības disbalansa rādītāji. Latviešu tautības svinētāju proporcija 2016. gadā sasniedza gandrìz $81 \%$, krievu tautības - vien $62 \%$. Sievietes par $10 \%$ vairāk nekā vīrieši iesaistijāas svētku norisēs. Cilvēki ar zemu izglìitibas līmeni reti piedalījās 18. novembra svētkos: vien 36,4\% aptaujāto ar sākumskolas izglìtibu vai nepabeigtu pamatizglìīibu atzīmēja Latvijas valsts dibināšanu. Savukārt gandrīz $90 \%$ no visiem bakalaura un mağistra grāda ieguvējiem iesaistijās svētku pasākumos. Raugoties pēc pamatnodarbošanās, 18. novembra svinētāju vidū salīdzinoši mazāk bija zemnieku (6o\%), pašnodarbināto un individuālo komersantu ( 53 \% no visiem), ilgstoši slimojošo un cilvēku ar īpašām vajadzībām (48\%). Vērojams, ka iedzīvotāji, klūstot
1. attēls. Latvijas valsts proklamēšanas dienas atzīmēšana 18 . novembrī (\%)

\begin{tabular}{|c|c|c|c|c|}
\hline \multirow[t]{2}{*}{2016} & \multicolumn{4}{|c|}{ |||||||||||||||||| } \\
\hline & A 17,4 & B 41,7 & c 16 & D 24,9 \\
\hline \multirow[t]{2}{*}{2014} & \multicolumn{4}{|l|}{ ||||||||||||||| } \\
\hline & 14,3 & 39,9 & 16,8 & 29 \\
\hline \multirow[t]{3}{*}{2010} & \multicolumn{4}{|c|}{ |||||||||||||||||||||- } \\
\hline & 21,8 & 29,6 & 18 & 30,6 \\
\hline & $\begin{array}{l}\text { A Atzimēiu } \\
\text { gzimenes vai } \\
\text { draugu lokă }\end{array}$ & \begin{tabular}{|l} 
B Apmeklekju \\
publiskus \\
pasaskumus
\end{tabular} & $\begin{array}{l}\text { c Atzimejeju } \\
\text { abos veidos }\end{array}$ & $\mid \begin{array}{l}\text { D Neatzīmēju } \\
\text { vispār }\end{array}$ \\
\hline
\end{tabular}

(Nacionālā identitāte, 2010, 2014; SUSTINNO, 2016

gados vecāki, aizvien retāk atzīmē valsts dzimšanas dienu. Vecuma grupā 18-24 gadi svinētāji veidoja $86 \%$, 25-34 gadi-gandrīz $80 \%$, 35-44 gadi- $76 \%$, 45-54 gadi -71,5\%, 55-64 gadi-71\% un $64-74$ gadi-67,7\%. Šì lejupejošā lïkne skaidrojuma ar galveno svētku notikumu norises formātu - tie ir publiskie pasākumi, kas norisinās pilsētvidē. Gados vecākiem cilvēkiem tos apmeklēt tumšā un aukstā laikā nereti liedz veselības stāvoklis. Turklāt svētku organizatoriskā līmenì tiek akcentēta gados jaunākās paaudzes iesaiste. Piemēram, tiek veidoti rīki, lai dalībnieki savu klātbūtni svētkos iespējami ērti varētu atainot sociālajos tỉklos, darbojas arī speciāli tēmturi. Tādējādi ar šo aktivitāti ir iespējams operatīivi apliecināt savas identitātes vērtības un veidot paštēlu sociālo tīklu lietotāju auditorijā un ar to interaktīvajiem rỉkiem (piemēram, dalīšanos, Like zīmi) gūt identitātes apstiprinājumu sociālo tīklu draugu un sekotāju auditorijā. Šis paradums arī daudz vairāk izplatîts gados jaunāko cilvēku un mobilo ieriču lietotāju vidū nekā gados vecākajā paaudzē. Citi svētku neatzìmētāju grupas raksturlielumi ir visai tuvi sociāli atstumto cilvēku grupas rādītājiem. Cilvēki, kuri dzivēe ir guvuši labākus panākumus, arī jūtas piederīgāki svētkiem un lỉdz ar to valstij, kā arī to publiski apliecina, iesaistoties Latvijas valsts proklamēšanas dienas svinībās (SUSTINNO, 2016).

2017. gada 18. novembra svētku priekšvakarā veiktā 18-60 gadus vecu Latvijas iedzivotāju aptauja liecināja, ka $39 \%$ jeb gandrīz pusmiljons iedzivotāju valsts neatkarības proklamēšanas dienā parasti apmeklē kādu svētku pasākumu - karaspēka parādi, salūtu vai ko citu. Ceturtā daḷa (25\%) respondentu šos svētkus svin mājās radu un draugu lokā, un $23 \%$ iedzivotāju 18. novembra svētku norises vēro televīzijas raidijumos $(23 \%)$. Trešajai dalai ( $34 \%$ aptaujāto 


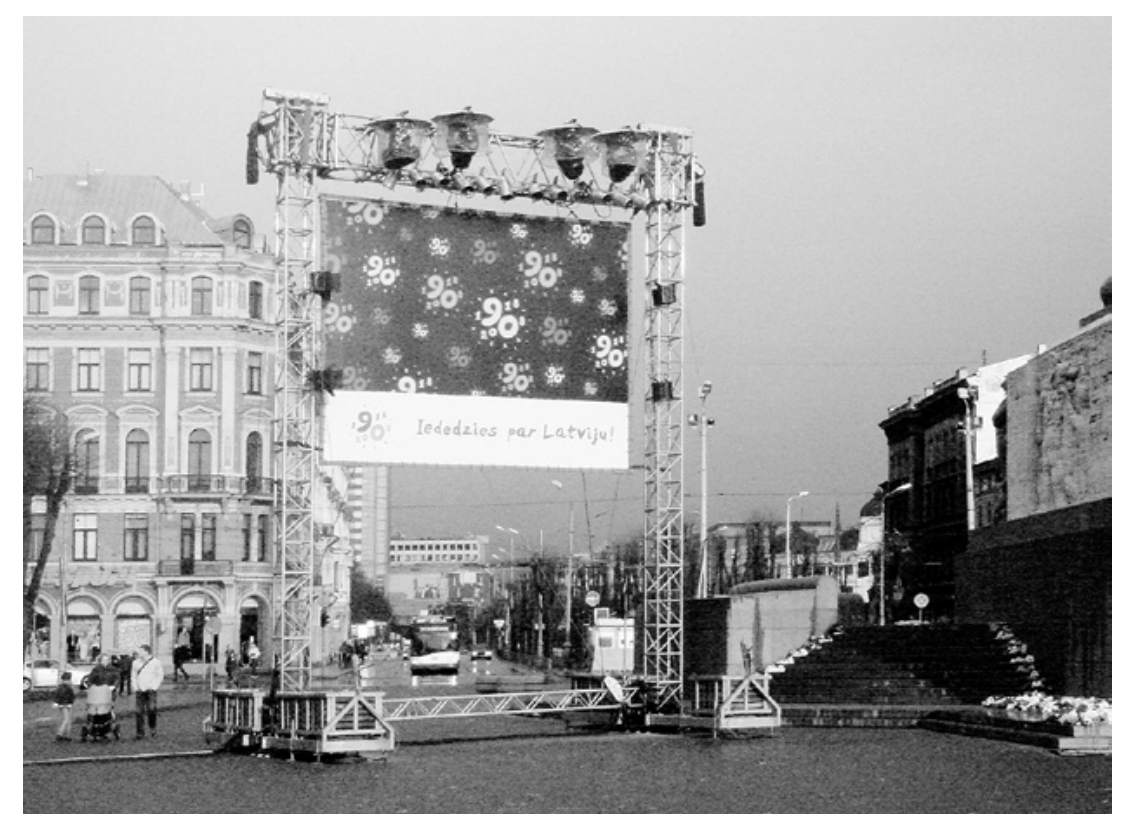

1. Latvijas Republikas 9o.gadadienas svinibu vides dekorativais stends pie Brivibas pieminekla. 2008.gada 17. novembris.

2. Latvijas Republikas 90. gadadienas svinibu gaismas vides instalâcija pie Ministru kabineta. 2008. gada 17. novembris
3. Latvijas Republikas 9o.gadadienas svinibu gaismas dekors uz Rigas dzelzcela pasažieru stacijas ëkas sienas. 2008. gada 10. novembris

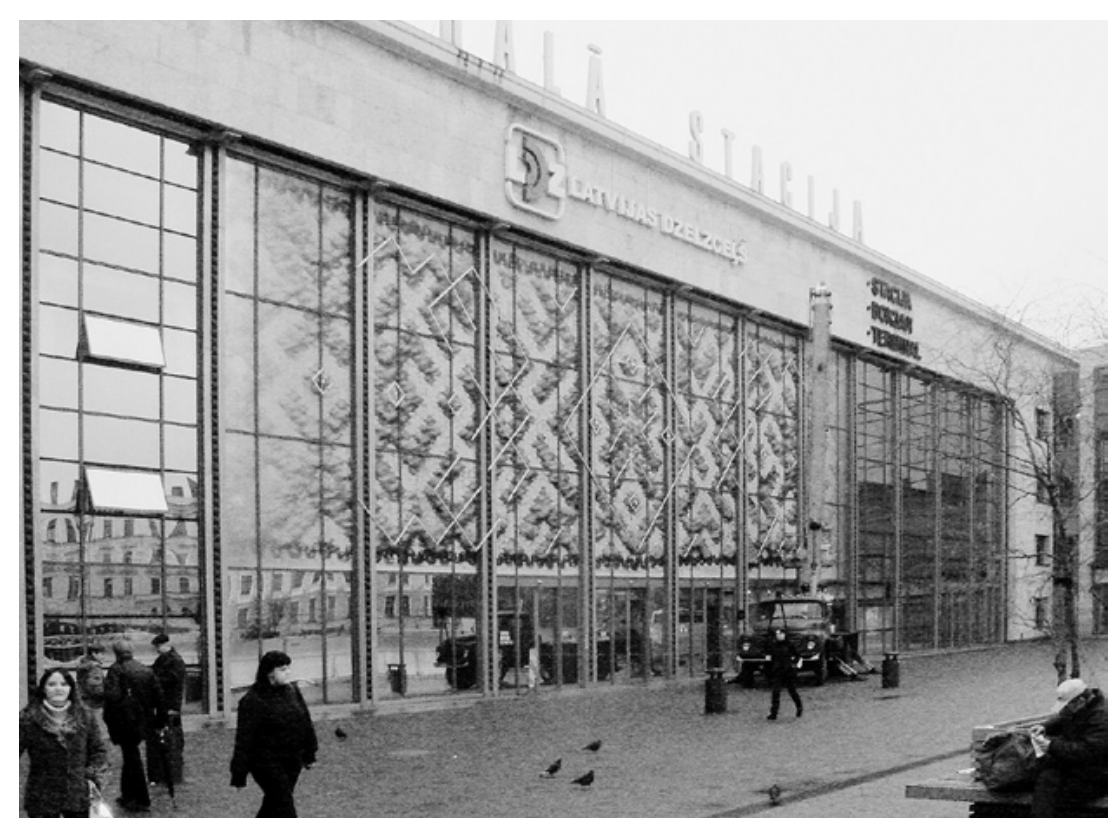

4. Latvijas Republikas 100. gadadienas svinibu LCD ekrānu vides instalācija pie Ministr kabineta. 2018.gad 25. februāris.

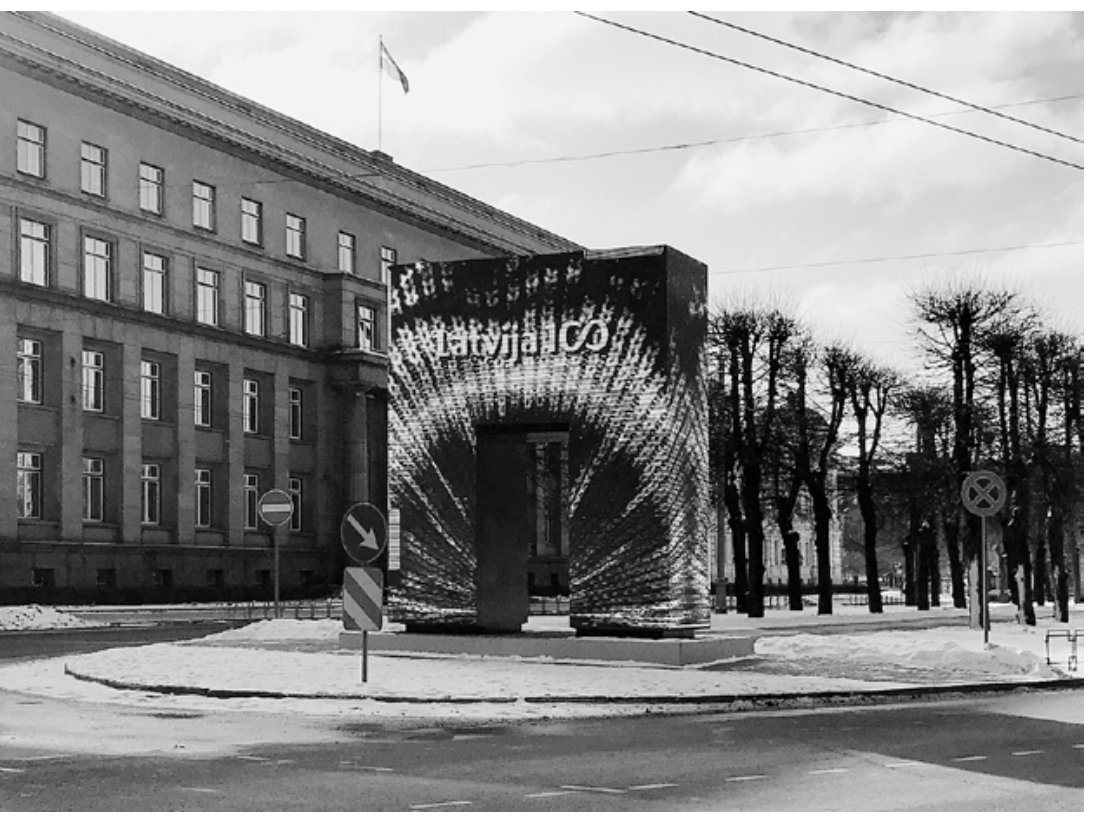


iedzivotāju 18. novembris ir parasta brīvdiena. Latvijas valsts proklamēšanas svētkus biežāk svin ğimenēs, kurās runā latviešu valodā. Savukārt ğimenēs, kuru saziņas valoda nav latviešu valoda, 18. novembri izbauda kā parastu brìvdienu un to īpaš nesvin (Kantar TNS, 2017g).

Būtiska nozime Latvijas valsts svētku iesakṇošanā ir to svinēšanas kontinuitātei, ko nodrošina valsts dalïba svinību menedžmentā un finansējumā, kā arī Latvijas valsts 10o. gadadienas svinību nozīmes uzsvērums publiskajā telpā kopš valsts 90. dzimšanas dienas atzimēšanas. Jau 2014.gada beigās Latvijas valsts simtgades norišu organizācija nonāca Kultūras ministrijas pārziñā un tika uzsākta simtgades programmas mērķu un pamatprincipu, programmu un komunikācijas vadlīniju izstrāde. Simtgades svētku pasākumi iecerēti laikposmā

no 2017. līdz 2021. gadam, ir uzsākta programmas ìstenošana, darbojas Latvijas valsts simtgades birojs un informācijas centrs, izveidota un tiek plaši lietota Latvijas valsts simtgades svinību piederības zīme, funkcionē arī platforma lv10o.lv, izveidota Simtgades loterija, notiek daudzi pasākumi un lïdzdarbošanās akcijas, simtgades vārds intensīvi tiek skandēts publiskajā telpā.

Svētku budžets pieciem gadiem plānots 59 miljonu eiro apjomā, no tiem 32 miljonus eiro veido valsts finansējums, un 27 miljoni eiro nāk no citiem avotiem (lv10o.lv). Publiskajā telpā ir izskanējušas diskusijas par šā finansējuma lielumu, norādot, ka kaimiņvalstīs simtgades svētku izmaksas ir mazākas (piemēram, Igaunijas simtgades svētku budžets ir 24 miljoni eiro un Somijas - 19 miljoni eiro). Vairāki kultūras darbinieki ir arī norādỉjuši, ka šis bagātīgais finansējums un valsts pasūtijumi nogalina svētku rīkošanas un svinēšanas brivprātības un solidaritātes ideju (Lūsin̨a, 2016; Langa, 2017; Karlsone, 2017)

2017. gada 29. novembrī portālā manabalss.lv pēc Alvila Puriča Aurela ierosmes ir izveidota iniciatīva «Simtgades svinỉbu naudas novirzišana vēža ārstēšanai!», kas tiks iesniegta Saeimā. Tajā norādīts:

Vai tiešām ir nepieciešamas tik dārgas svinïbas? [..] Nozīmigas problēmas onkoloğijā ir efektîvāku zāḷu kompensēšana iedzivotājiem, kā arī finansējums operācijām un kịmijterapijai. Vismaz pusei vēža pacientu pēc operācijas ir nepieciešama ḳimijterapija vai staru terapija. Lìdzekḷu trūkuma dēḷ vēža pacientiem, ar retiem izṇēmumiem, netiekot kompensēta mērḳterapija, kas iznīcina vēža šūnas, blokẹējot to augšanu. Šãdi tiek kavēta iespēja apturēt vēža attīstibu (manabalss.lv, 2018).

Krūts vēža pacientu atbalsta biedribas «Vita» 2017. gadā veiktās aptaujas rezultāti liecina, ka $76 \%$ respondentu vēlētos, lai daḷa no simtgadei paredzētajiem naudas līdzekliem tiktu novirzìta vēža pacientu ārstēšanai, savukārt 15\% šì doma drīzāk škiet pareiza nekā nepareiza (Biedrība «Vita», 2017). Jautājums: vai Latvijas simtgadei atvēlētie lỉdzekḷi tiek tērēti lietderīgi un godīgi-publiskajā telpā tiek uzdots nemitīgi (Gabre, 2018). 2018. gada janvārī mediju uzmanības centrā nonāca 247000 eiro vērtā mākslas objekta «Goda vārti» uzstādišana un tās paātrināta konkursa norise, kas sēj šaubas par atsevišķu amatpersonu godprātigu attieksmi pret saviem pienākumiem (TVNET, 2018).

2018. gada sākumā veiktās aptaujas rezultāti liecina, ka valsts 100 dzimšanas dienas gada ieskaṇā iedzīvotāju attieksme pret to nav viennozimiga. Atbildot uz jautājumu - vai valsts simtgades gads jums ir personigi nozimìgs -, gandrīz puse jeb $46 \%$ aptaujāto Latvijas iedzivotāju vecumā no 18 līdz 60 gadiem atzina, ka šis gads viņiem ir personigi nozimìgs. Tomēr tikpat daudziem iedzivotājiem (46\%) simtgades gads nav personigi nozìmigs. $8 \%$ respondentu nebija viedokḷa par savu attieksmi pret šo gadu. Atbildot uz jautājumu par pasākumiem, kurus tiek plānots apmeklēt, $19 \%$ aptaujāto norādijja, ka dosies uz Vislatvijas koprades gaismas projektu «Staro» un gaismas uzvedumu 11. novembra krastmalā. 15\% iedzìvotāju plāno apmeklēt XXVI Vispārējos latviešu dziesmu un XVI deju svētkus. Savukārt $21 \%$ respondentu norādīja, ka viṇi neplāno apmeklēt nevienu no Latvijas simtgadei veltìtajiem pasākumiem. $24 \%$ iedzivotāju atzina, ka šobrīd viniem ir «grūti pateikt», uz kādiem simtgades pasākumiem vini varētu doties. Svētku programmā aktīvi iesaistìties (proti, apmeklēt visus pasākumus) gatavi ir 13\% aptaujāto cilvēku (Kantar TNS, 2018).

Latvijas simtgades svētku organizācijas formāts ir līdz šim vērienīgākais un ar visizteiktāko profesionālu menedžeru, sabiedrisko attiecību speciālistu un citu jomu darbinieku iesaisti kopš valstiskuma atgūšanas 1991. gadā. Šo svētku svinību pieredzes izvērtējums katrā zinā laus izdarìt secinājumus par svētku, rituālu, simbolisku darbỉbu jēgu un nozīmi valsts un iedzivotāju attiecībās, kā arī valsts menedžmenta efektivitāti un jēgu svētku svinēšanā. Valsts simtgades svinïbu iespēja ir stiprināt Latvijas iedzīvotāju nacionālo un politisko identitāti. Vienlaikus tām ir arī potenciāls padziḷināt anomijas situāciju tajās sociālajās grupās, kuras sajutis atstumtību un kuras svētku norises un tajās ieguldìto līdzekḷu tērēšanu definēs kā negodīgu un/vai netaisnīgu.

Popularitātes ziṇā nākamie visvairāk svinētie svētki aiz Latvijas valsts dibināšanas dienas 18. novembrĩ ir LĀČPLËŠA DIENA 11. NOVEMBRİ, kas tiek atzimēti gan kā patstāvigi svētki, gan valsts dibināšanas svētku nedēlas ievads. Lāčplēša diena veltita Latvijas armijas uzvarai pār Bermonta karaspēku 1919. gadā Rīgā; šis kaujas iznākums bija izšķirošais Brīvỉbas cinnu gaitā. Lāčplēša dienas rituālos ieklaujas pieminas dievkalpojumi Latvijas baznīcās, ziedu nolikšanas ceremonija Rīgas Brālu kapos ar augsstu amatpersonu 
2. attēls. Lāčplēša dienas atzīmēšana 11. novembrī (\%)

\begin{tabular}{|c|c|c|c|c|c|}
\hline \multirow[t]{2}{*}{2016} & \multicolumn{5}{|c|}{ ||||||||||||||||| } \\
\hline & A 15,2 & B 31,8 & & c 9,4 & D 43,6 \\
\hline \multirow[t]{2}{*}{2014} & \multicolumn{5}{|l|}{||||||||||||} \\
\hline & 11,9 & & & 10,2 & 47,6 \\
\hline \multirow[t]{3}{*}{2012} & \multicolumn{5}{|c|}{||||||||||||||||||||} \\
\hline & 17,9 & 22,3 & & 8,5 & 51,2 \\
\hline & $\begin{array}{l}\text { A Atzīmēju } \\
\text { gimenes vai } \\
\text { draugu lokāa }\end{array}$ & & $\begin{array}{c}\text { B Apmeklēju } \\
\text { publiskus } \\
\text { pasākumus }\end{array}$ & $\begin{array}{l}\text { c Atzīmēju } \\
\text { abos veidos }\end{array}$ & $\mid \begin{array}{c}\text { D Neatzimēeju } \\
\text { vispâr }\end{array}$ \\
\hline
\end{tabular}

(Nacionālā identitāte 2010, 2014; SUSTINNO, 2016)

3. attēls. Neatkarības deklarācijas pieṇemšanas dienas atzīmēšana 4. maijā (\%)

\begin{tabular}{|c|c|c|c|c|}
\hline \multirow[t]{2}{*}{2016} & \multicolumn{4}{|c|}{|||||||||| $\mid$} \\
\hline & A 10,6 B 13,4 & c 2,6 & & D 73,5 \\
\hline \multirow[t]{2}{*}{2014} & \multicolumn{4}{|l|}{$\|||||||||$} \\
\hline & 15,3 & 3,7 & & 71,6 \\
\hline \multirow[t]{3}{*}{2010} & \multicolumn{4}{|c|}{ 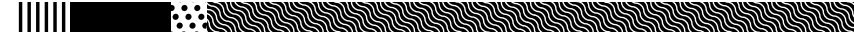 } \\
\hline & \multicolumn{3}{|c|}{$\begin{array}{lll}6,4 & 12 & 4,2\end{array}$} & 77,5 \\
\hline & $\begin{array}{l}\text { A Atzīiēju } \\
\text { gimenes vai } \\
\text { draugu lokāa }\end{array}$ & $\mid \begin{array}{c}\text { B Apmeklejiu } \\
\text { publiskus } \\
\text { pasâkumus }\end{array}$ & $\mid \begin{array}{l}\text { c Atzìmëju } \\
\text { abos veidos }\end{array}$ & $\mid \begin{array}{c}\text { D Neatzimēju } \\
\text { visparr }\end{array}$ \\
\hline
\end{tabular}

(Nacionālā identitāte 2010, 2014; SUSTINNO, 2016)

piedalīšanos, militārā parāde pie Brīvỉbas pieminekḷa, Valsts prezidenta svinịgā uzruna, lāpu gaajiens no Brālu kapiem līdz Brīvỉbas piemineklim. Svētku kulmināciju veido svecīšu sienas veidošana pie Rīgas pils mūra, kas ir spilgtākā cilvēku līdzdalības darbība šajos svētkos. Arī citās Latvijas pilsētās un novados šì diena tiek svinēta un notiek kolektivi un individuāli svecišu un ugunskuru dedzināšanas pasākumi.
Socioloğisko aptauju datu analīze liecina, ka 11. novembra svinētāju kopportrets ir līdzīgs 18. novembra atzīmētāju raksturojumam. Arī Lāčplēša dienas norisēs salīdzinoši daudz vairāk iesaistās jaunākā paaudze. Piemēram, 2016. gadā vecumgrupā 18-24 gadi šos svētkus svin $68 \%$ respondentu, bet vecumgrupā $64-74$ gadi-42,3\%. Vērojama arī etniskā škirtne attieksmē pret Lāčplēša dienu. To atzīmē $64,5 \%$ aptaujāto latviešu un 31,2 \% krievu. Svinībās vairāk piedalās cilvēki ar salīdzinoši augstāku izglìtỉbas līmeni un sekmīgām darba gaitām (SUSTINNO, 2016).

2017. gada rudenī veiktās aptaujas rezultāti vēsta, ka togad Lāčplēša dienu plānoja atzīmēt $51 \%$ Latvijas iedzìvotāju vecumā no 18 lïdz 55 gadiem. $24 \%$ respondentu to svinēs mājās tuvinieku un draugu lokā, $16 \%$ piedalīsies kādā 11. novembra Latvijas varoṇu pieminas pasākumā, $10 \%$ iedzīvotāju dosies nolikt svecìtes pie Rīgas pils mūra, $7 \%$ aptaujāto plāno piedalīsies kādā Lāčplēša dienai veltītā koncertā vai dosies uz militāro parādi, un 1\% iedzīvotāju dosies uz ippašo dievkalpojumu baznīcā (Kantar TNS, 2017f). Lāčplēša dienas popularitāti un tās nozìmes apjēgsmi veicināja vēsturiskā filma «Rịgas sargi» (2007, rež. Aigars Grauba), kas ataino 1919. gada novembra notikumus un ir iemantojusi lielu skatītāju auditoriju un atzinību.

Svētku brīvdiena ir NEATKARĪBAS DEKLARĀCIJAS PIENEMŠANAS DIENA 4. MAIJĀ. Tās oficiālo pamatrituālu veido Saeimas svinīgā sēde un ziedu nolikšana pie Brīvības pieminekḷa. 2016. gadā pēc Latvijas valsts simtgades biroja aicinājuma tika dibināta jauna tradīcija - Baltā galdauta svētki. To ideja ir kopā pulcēt cilvēkus uz svētku maltīit kopienas, ğimenes, pagalma, draugu un darba kolēĝu lokā, tādējādi veicinot kopības un piederības valstij sajūtu. Latvijas valsts simtgades birojs ne tikai plaši popularizē Baltā galdauta svētkus, bet arī piedāvā Baltā galdauta svētku svinēšanas rekomendācijas. Tajās ipaši uzsvērts, ka ar balti klātu svētku galdu Latvijas Neatkarības atjaunošanas svētkus var atzīmēt jebkurā pasaules malā, tã arì svētku norisē iesaistot diasporu, uz ìsāku vai ilgāku laiku no Latvijas izbraukušos cilvēkus un tās draugus citās valstīs. 2016. gadā šo svētku svinēšanā iesaistijās 93 ooo cilvēku (lv10o.lv). 4. maijā norit arì daudzi citi svētku pasākumi. Par noturïgu tradīciju veidojas floristikas objekta «Ziedu Latvija» veidošana un pūtēju orkestru defilē pie Brīvības pieminekḷa, Latvijas filmu maratons kinoteātrī Splendid Palace. Notiek arī svētku koncerti, vakara lielkoncerts 11. novembra krastmalā, svētku salūts. 2017. gadā kā veltījums Latvijas valsts simtgadei pierobežā notika ozolu stādīšanas akcija «Apskauj Latviju» (Krauze, 2017). Arī šiem svētkiem ir pakārtota sabiedrisko mediju dienaskārtība.

Aptauju rezultātu analīze vēsta, ka arī 4. maija svinētāju loks kopumā ir tāds pats kā jau aplūkotajiem svētkiem 11. novembrī un 18. novembrī, tomēr dati liecina, ka šo svētku pasākumos iesaistās mazāk cilvēku. Baltā galdauta svētku tradīcijas izveides nolūks ir Neatkarības deklarācijas pienemšanas dienas iesaknošana svinēšanas praksē. 4.maijs kā svētki ir jauna 


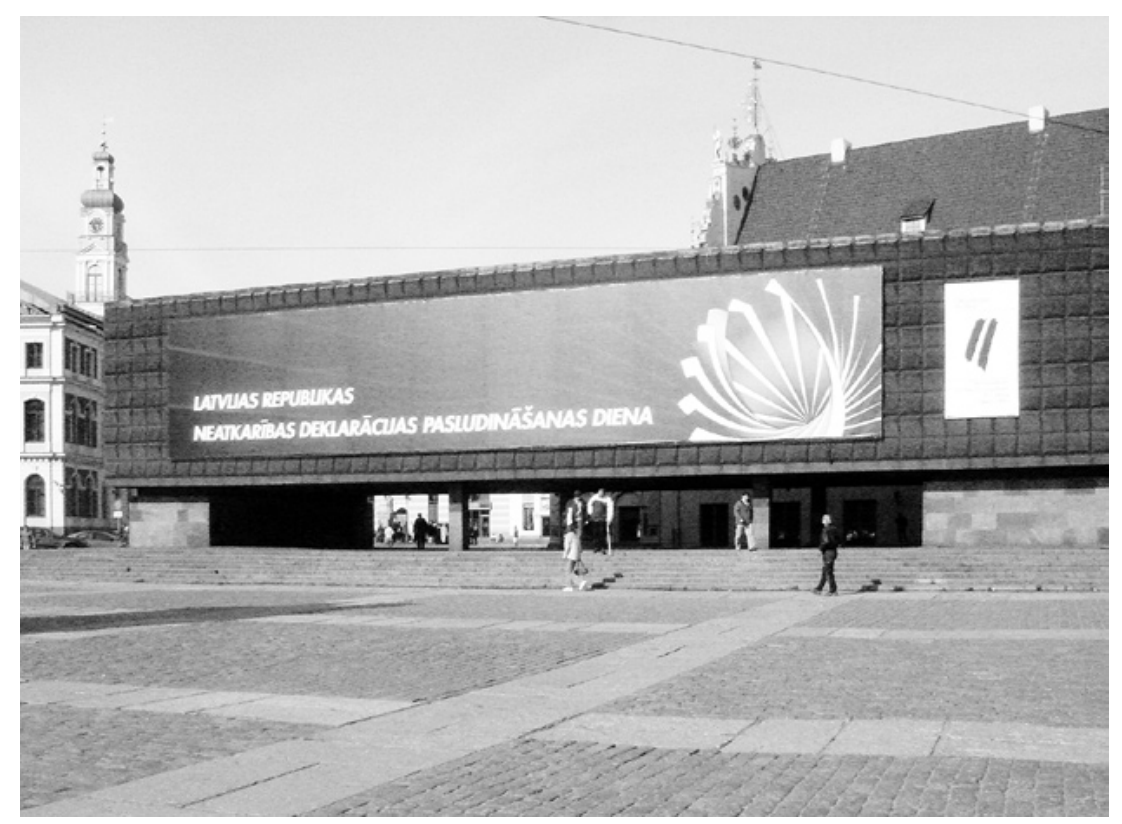

5. Latvijas Republikas

Neatkaribas pas

šanas dienai veltitais

vides plakāts uz Latvijas

Okupācijas muzeja

èkas sienas. 2007.gada

3. maijs.

7. Latvijas Republikas Neatkaribas pasludināšanas dienai veltitais floristikas objekts «Ziedu Latvija» pie Brivibas 4. maijs.
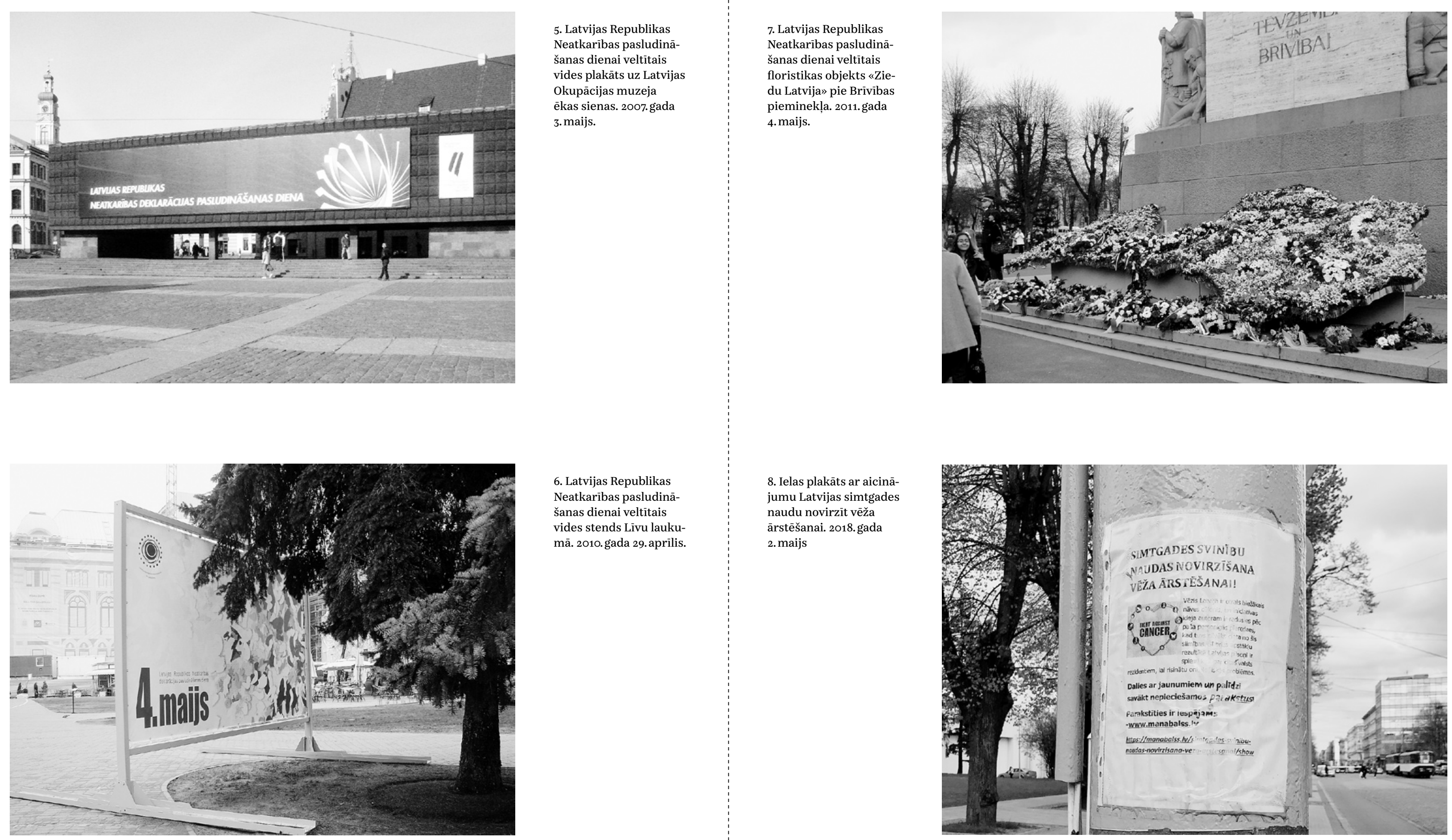

6. Latvijas Republikas Neatkaribas pasludināšanas dienai veltitais vides stends Livu laukumā. 2010. gada 29. aprilis.
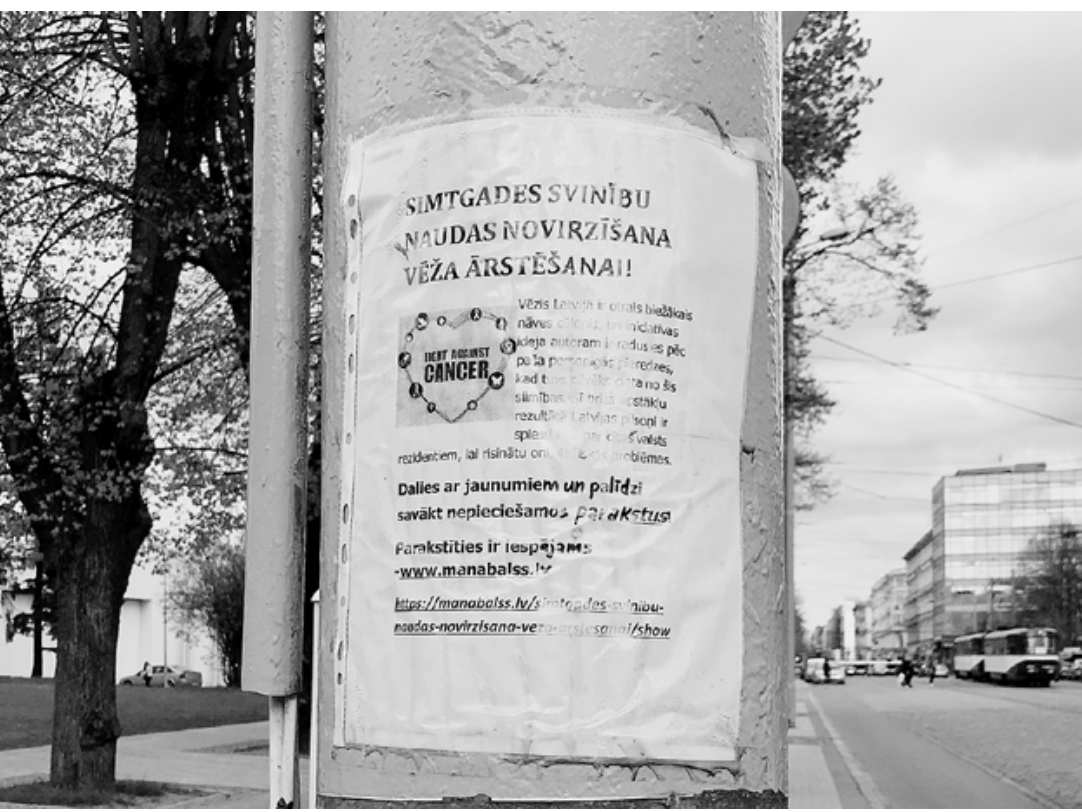

8. Ielas plakāts ar aicinājumu Latvijas simtgades ārstēšanai. 2018. gada 2. maijs 
parādība - atškirībā no Lāčplēša dienas un Latvijas valsts proklamēšanas dienas, kas tika svinētas arī 2o.gs. 20. un 3o.gados, savukārt padomju okupācijas periodā to atcerēšanās vai klusa atzīmēšana kalpoja kā opozīcijas apliecinājums pastāvošajam režīmam. Prognozējams, ka, pateicoties valsts un pašvaldību institūciju menedžmentam un finansiālajam atbalstam, Neatkarības deklarācijas pieṇemšanas dienas svinēšanas prakse pakāpeniski vērsīsies plašumā. 4. maija pārtapšanu par plaši svinētiem svētkiem veicina arī šo svētku vieta gada kalendārā, kad jau iestājies pavasaris un pārsvarā silts, dažkārt pat saulains laiks, kas ḷaudis mudina atrasties ārpus telpām un priecāties par ziedoṇa atnākšanu.

Latvijas valsts svētku kalendārā brīvdienas statuss ir arī SATVERSMES SAPUlCES SASAUKŠANAS DIENAI 1. MAIJĀ. Tās misija ir akcentēt valsts pamatlikuma - Satversmes - un tajā iekḷauto demokrātisko vērtỉbu nozīmi. Šās svētku dienas atzīmēšanai nav iedibināti noturīgi oficiālie rituāli. Vairākkārt Satversmes sapulces sasaukšanas dienā valsts amatpersonas ir nolikušas ziedus pie pirmā Valsts prezidenta Jāṇa Čakstes pieminekḷa un atdusas vietas Meža kapos. Pēdējos gados tiek izplatîts Valsts prezidenta Raimonda Vējona ipašs apsveikums Satversmes sapulces sasaukšanas dienā. 2016. gadā veiktajā aptaujā nepilni $9 \%$ respondentu atzina, ka atzīmē šos svētkus. Jāpiebilst, ka Latvijas valsts svētku kalendārā 1. maijā tiek atzīmēti divi svētki-Satversmes sapulces diena un DARBA SVĒTKI, kuru uzdevums ir atgādināt par strādājošo tiesībām un kurus atzīmē ḷoti daudzās pasaules valstīs. Latvijā šo svētku galvenie organizatori ir Latvijas Sociālistiskā partija (LSP), Latvijas Sociāldemokrātiskā strādnieku partija (LSDSP), partija «Saskana» un arodbiedrïbas. Vinu rīkotie publiskie pasākumi nepiesaista plašu svinētāju loku, tomēr ir vērojama tendence iedibināt jaunus pievilcīgus rituālus, kas, piemēram, aizstātu vai sekmīgi konkurētu ar jau ilglaicīgi LSP rīkoto mìtinu Grīzinkalnā vai LSDSP pasākumiem pie Raina pieminekḷa Esplanādē. 2017. gadā arodbiedrība LABA saviem biedriem un viṇu ğimenes locekḷiem rīkoja gājienu, grupas «Vintāža» koncertu un siltas pusdienas. Pasākuma dalībniekus arī vienoja koši sarkanas krāsas jakas, cepurìtes, arodbiedrības karogi un baloni, viṇus apsveica ne vien organizācijas vadītāji, bet arī Rīgas pilsētas mērs Nils Ušakovs (LABA, 2017). Pēc 2016. gada aptaujas datiem, Darba svētkus Latvijā svin nepilns $21 \%$ respondentu. Lielākā dala valsts iedzīvotāju 1. maiju izmanto kā parastu brīvdienu.

Valsts atzimējamo dienu kalendārā iekḷauto Latvijas Republikas valstiskuma veidošanai un Brīvibas cīnu notikumiem veltìto dienu sarakstā ir arī 26. janvāris - Latvijas Republikas starptautiskā atzišana-, 22. jūnijs -Cēsu kaujas - un 11. augusts - Briviibas ciñu noslēgums. 26. JANVĀRA ATCERES PASĀKUMUS rỉko Ārlietu ministrija. Šã valstiski nozimigāā notikuma atzīmēšanas ikgadējie rituāli ir ārvalstu diplomātu svinigāa pienemšana, ārlietu ministra runa, Latvijas ārpolitikas sasniegumiem un/vai to vēsturei veltitu grāmatu un/vai izstāžu prezentācija, ziedu nolikšana Meža kapos pie mūžìbā aizgājušo izcilo diplomātu kapavietām. Atsevišḳi pasākumi tiek rīkoti arī Latvijas diplomātiskajās pārstāvniecībās vai citās ārvalstu institūcijās (piemēram, skat. Ārlietu ministrija, 2015, 2017, 2018a, 2018b). Latvijas Republikas starptautiskās atzišanas dienas atceres pasākumi arī noklūst mediju dienaskārtībā, galvenokārt pateicoties augsstu valsts amatpersonu klātbūtnei.

CĒSU KAUJU ATCERES PASĀKUMI 22. JŪNIJĀ galvenokārt norisinās Vidzemē, protams, to kulminācijas vieta-Cēsis, kur pēdējos gados tiek piedāvāta svētku programma visas dienas ilgumā. Tajā iekḷauta ne vien kritušo karaviru godināšana, augstu Latvijas un Igaunijas amatpersonu, Nacionālo brunoto spēku komandieru runas, bet arī patriotiskas noskanas izklaides pasākumi - Cēsu kauju rekonstrukcija (kopš 2015.gada), orientēšanās spēles, koncerti, zaḷumballe. Svētku pasākumu galvenais menedžments un satura veidošana atrodas Cēsu novada pašvaldỉbas un Cēsu Vēstures un mākslas muzeja zinā (Cēsu novada pašvaldība, 2017). Būtiska nozīme ir arī vietējo cilvēku iniciatīvai un ieinteresētībai. Cēsu kauju rekonstrukcijas ideja un isstenošanas ierosme pieder uzṇēmējam Renāram Sproğim un vina domubiedriem. «Manuprāt, kauju rekonstrukcija, kas faktiski ir šovs ar iespēju robežās pietuvinātu režiju reālajiem notikumiem, ir labs veids, kā ieinteresēt cilvēkus, likt aizdomāties par Latviju un to, cik smagas ir bijušas mūsu valstiskās brīìibas cinnas,» intervijā atzìst R. Sprogis. Viṇš arī norāda, ka Cēsu kauju atceres diena «uzṇem arvien lielākus apgriezienus» un vērienīga kauju rekonstrukcija tiek plānota šā Brīiības cīnu nozìmīgā notikuma simtgadē 2019. gadā (Jasinska, 2017). Izklaidējošās pagātnes performances un līdzdalības pasākumu ieklaušana Cēsu kauju atceres dienu ir pārvērtusi par apmeklētiem svētkiem, kuru dalībnieku vidū ir aizvien vairāk jauniešu (Asare, 2017).

BRİVīBAS CĪNU NOSLĒGUMA 11. AUGUSTĀ atceres dienai nav izveidojušās stabilas atzīmēšanas prakses. Šim notikumiem par godu ir tikuši rikoti atsevišḳi pasākumi ar valsts amatpersonu un akadēmisko aprindu pārstāvju piedalīšanos, tajos nereti galvenā uzmanība tiek veltīta Latvijas un Krievijas miera līguma noslēgšanai 1920. gada 11. augustā, tā nozīmes un pildīšanas izvērtējumam.

Pēdējā laikā izskan iniciatīvas papildināt valsts un patriotisko svētku klāstu. Piemēram, valdības atbalstu guvis jau minētais Aizsardzības ministrijas ierosinājums 10.jūliju pasludināt par Karavīu dienu. 1919.gada 10. jūlijā, apvienojot pulkveža Jāṇa Baloža Dienvidlatvijas atsevišḳo brigādi un pulkveža Jorğa Zemitāna Ziemellatvijas brigādi, tika izveidota vienota Latvijas armija, tālab šis datums tiek uzskatìts par Latvijas armijas dzimšanas dienu. 10. jūlijā jau kopš 2010. gada risinās iniciatīva «Pasveicini karaviru», proti, klātienē vai sociālajos tỉklos tiek sveikti karavīi un zemessargi un pateikts paldies par vinu dienestu. Savukārt zemessargi 10. jūlijā darbavietā ierodas 
(ja vien iespējams) lauka formas tērpos, tā demonstrējot, cik daudz Latvijā ir zemessargu (sargs.lv, 2017).

Latvijas nozīmīgāko valsts un patriotisko svētku klāstā līdzās aplūkotajiem valsts izveides vēsturei veltìtajiem svētkiem iekḷaujama arì 9. MAIJĀ atzīmējamā EIROPAS DIENA, kurā tiek cildināta Eiropas Savienības izveide. Šās dienas interaktīvais rituāls ir valsts pārvaldes un likumdošanas institūciju, kā arī ārvalstu vēstniecību «atvērto durvju» dienas. Svētku aktivitātes ir vērstas uz zināšanu par ES izplatîšanu gan skolēnu, gan citās auditorijās (ES māja, 2017). 2016. gada aptaujas dati liecina, ka Eiropas dienu atzīmēja 8,7\% respondentu. Tomēr šiem svētkiem ir liels attīstības potenciāls. Domājams, ka to nozīme svinību praksē pieaugs, ja mazināsies citu 9. maijā atzīmēto svētku - Padomju Savienības uzvaras Lielajā Tēvijas karā-svinēšanas vēriens.

Pēdējo desmit gadu laikā Latvijā ir izveidojusies un joprojām turpina veidoties labi organizēta, finansēta, jēgpilna un gan uz masām, gan noteiktām mērḳgrupām orientēta valsts un patriotisko svētku svinēšanas prakse, kurā liela loma ir kultūras norisēm, performatīvajām un līdzdalības formām. Tã arī novērš anomijas situācijas veidošanās cēloṇus un stiprina iedzīvotāju valstisko identitāti.

Komunistiskā un nacistiskā totalitārā režìma upuru piemiṇas dienas

Komunistiskā un nacistiskā totalitārā režìma upuru piemiṇas dienu atzīmēšanai bija īpaša nozìme, mobilizējot cilvēkus Latvijas valstiskuma atgūšanas atbalstam. Dalība tajās bija protests pret šo režīmu nodarīto netaisnību un tieši nerepresēto, tostarp arī ar šiem režimiem aktīvi kolaborējušo, simboliska parāda atmaksāšana cietušajiem. Pēdējā desmitgadē komunistiskā režima upuru dienas atceres galvenie pasākumi notiek ik gadus, lai gan nepulcina plašu dalībnieku loku. Nevienai no šim dienām nav piešķirts brīvdienas statuss.

14. JŪNUA UN 25. MARTA PADOMJU MASU DEPORTĀCLUU PIEMINAS DIENU pasākumu galvenais rīkotājs ir Latvijas politiski represēto apvienība, iesaistās arī citas kultūras un sabiedriskās institūcijas. Piemēram, 2017. gadā Rīgā to vidū bija fonds «Sibīrijas bērni», Kultūras un tautas mākslas centrs «Mazā ğilde», Sv. Pētera baznīcas pārvalde, Kara muzejs, Rīgas Latviešu biedrība un orḳestris «Rīga», pasākumi notika ar Rīgas pilsētas domes atbalstu. Galvaspilsētas centrālais publiskais pasākums ir gājiens no Okupācijas muzeja Rātslaukumā lỉdz Brīvỉbas piemineklim, kura dalībnieki galvenokārt ir represētie un vinu ğimenu locekḷi, arī ziedu nolikšanas ceremonija ar valsts augstāko amatpersonu un ārvalstu diplomātiskā korpusa piedalīšanos un sviniggā goda sardzes maina. Pēdējos gados šis pasākums kopā pulcē vairākus simtus dalībnieku. Pieminas pasākumi noris arī
4. attēls. 1941. gada 14.jūnija masu deportāciju upuru piemiṇas dienas atzīmēšana (\%)

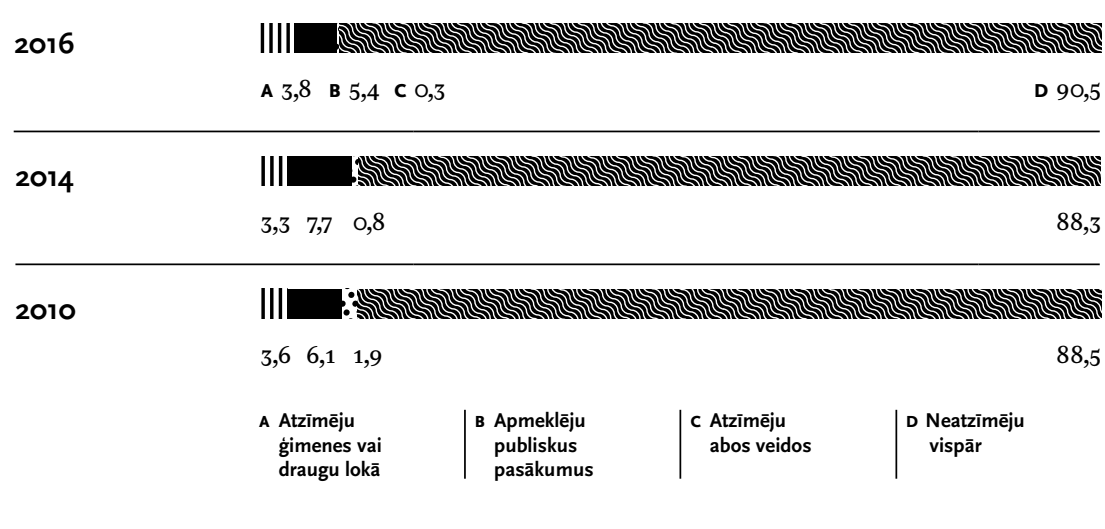

(Nacionālā identitāte 2010, 2014; SUSTINNO, 2016)

5. attēls. 1949. gada 25. marta masu deportāciju

upuru piemiṇas dienas atzīmēšana (\%)

\begin{tabular}{|c|c|c|c|c|}
\hline \multirow[t]{2}{*}{2016} & \multicolumn{4}{|c|}{ 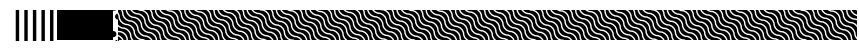 } \\
\hline & A 4,9 в 6,8 & & & D 87,8 \\
\hline \multirow[t]{2}{*}{2014} & \multicolumn{4}{|c|}{ : } \\
\hline & 4,99 & & & 84,7 \\
\hline \multirow[t]{3}{*}{2010} & \multicolumn{4}{|c|}{ 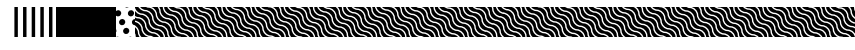 } \\
\hline & $4,9 \quad 7,5 \quad 2,3$ & & & 85,4 \\
\hline & $\begin{array}{l}\text { A Atzīimeju } \\
\text { gimenes vai } \\
\text { draugu lokā }\end{array}$ & $\begin{array}{c}\text { B Apmeklēiu } \\
\text { publiskus } \\
\text { pasăkumus }\end{array}$ & $\begin{array}{l}\text { C Atzìmēju } \\
\text { abos veidos }\end{array}$ & $\mid \begin{array}{l}\text { D Neatzimēju } \\
\text { vispâr }\end{array}$ \\
\hline
\end{tabular}

(Nacionālā identitāte 2010, 2014; SUSTINNO, 2016)

pie komunistiskā terora upuriem veltìtajiem pieminekḷiem Torṇakalnā un Škirotavā. Atceres pasākumam veltìtie koncerti galvenokārt notiek telpās ar 200-400 apmeklētājiem un piedāvā kvalitatīvu un nopietnu repertuāru. Masu deportāciju piemiṇas dienas tiek atzīmētas ḷoti daudzās Latvijas vietās, to pieminas pasākumu rīkošanas iniciatīvas pieder Latvijas Politiski represēto apvienības struktūrvienỉbām un vietējām pašvaldībām. Nereti šì 


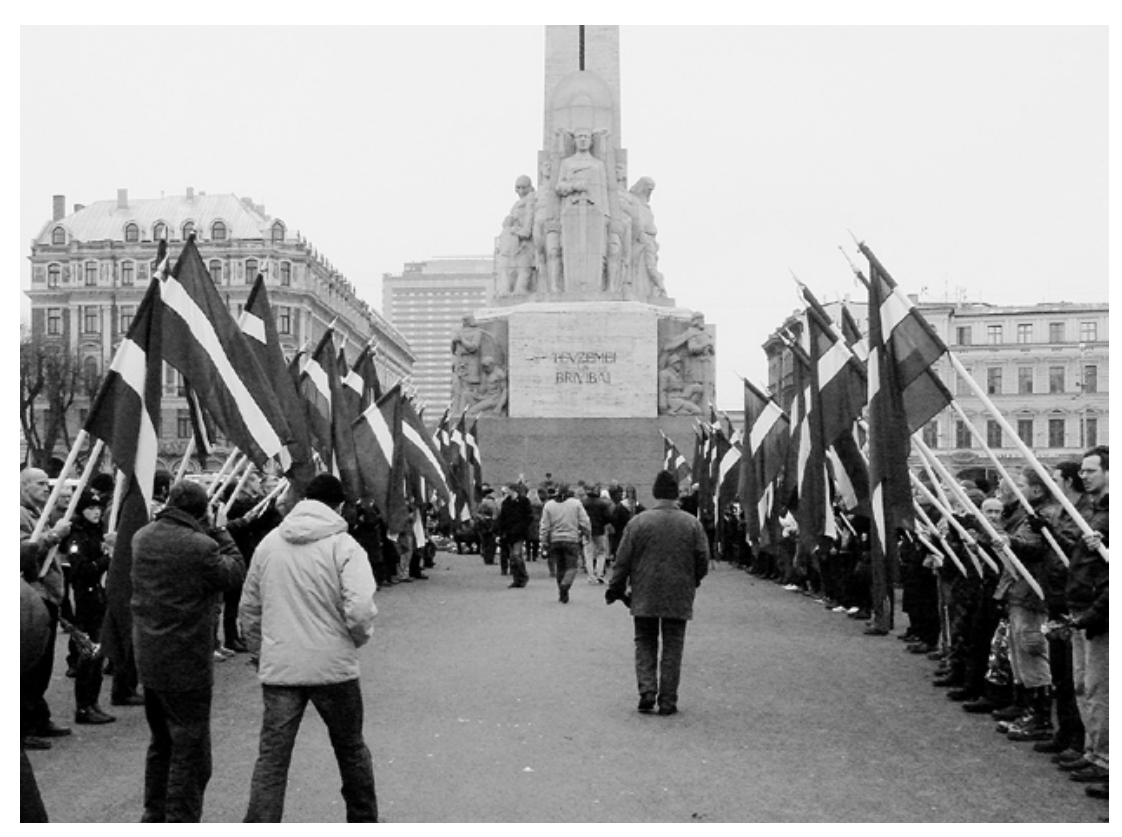
Brivibas piemineklla.

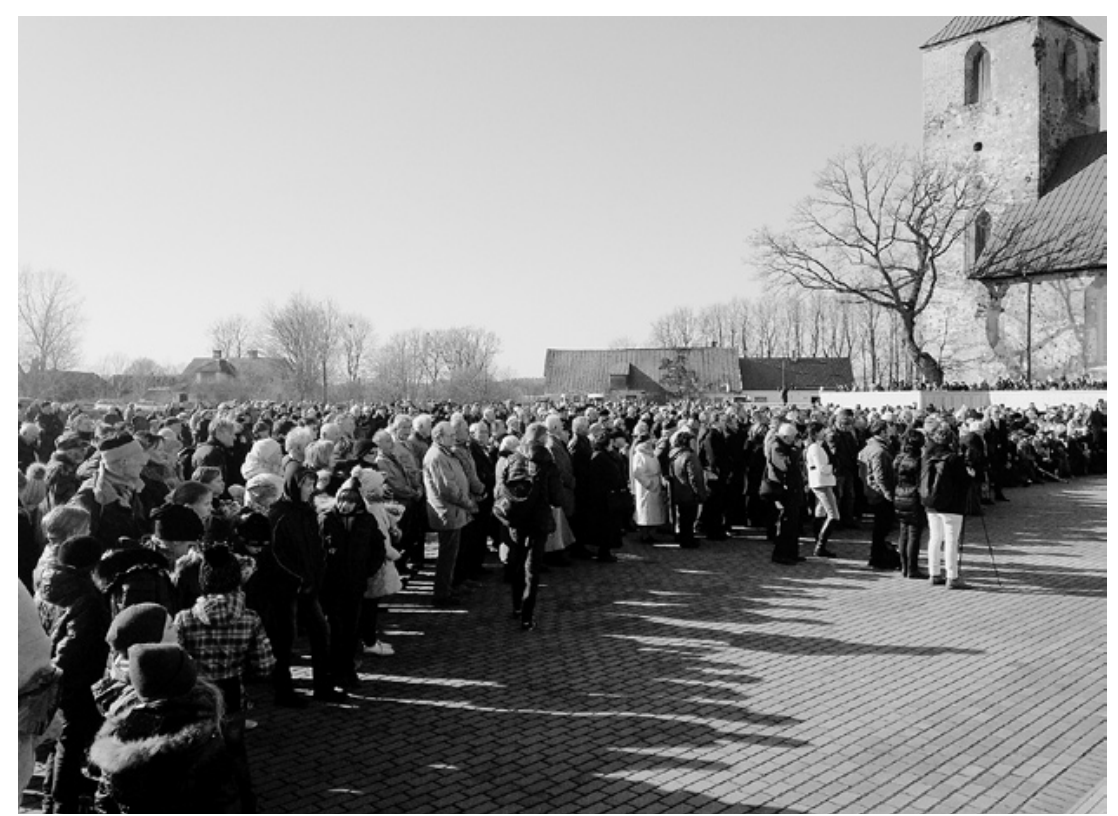

9. Latviešu leğionāru pieminas dienas pasākuma karogu aleja pie 2009. gada 16. marts.

11. Komunistiskā genodienai 25. martā veltito pasākumu afiša Krišsjāna Valdemāra ielā. 2014. gada 14. aprilis.

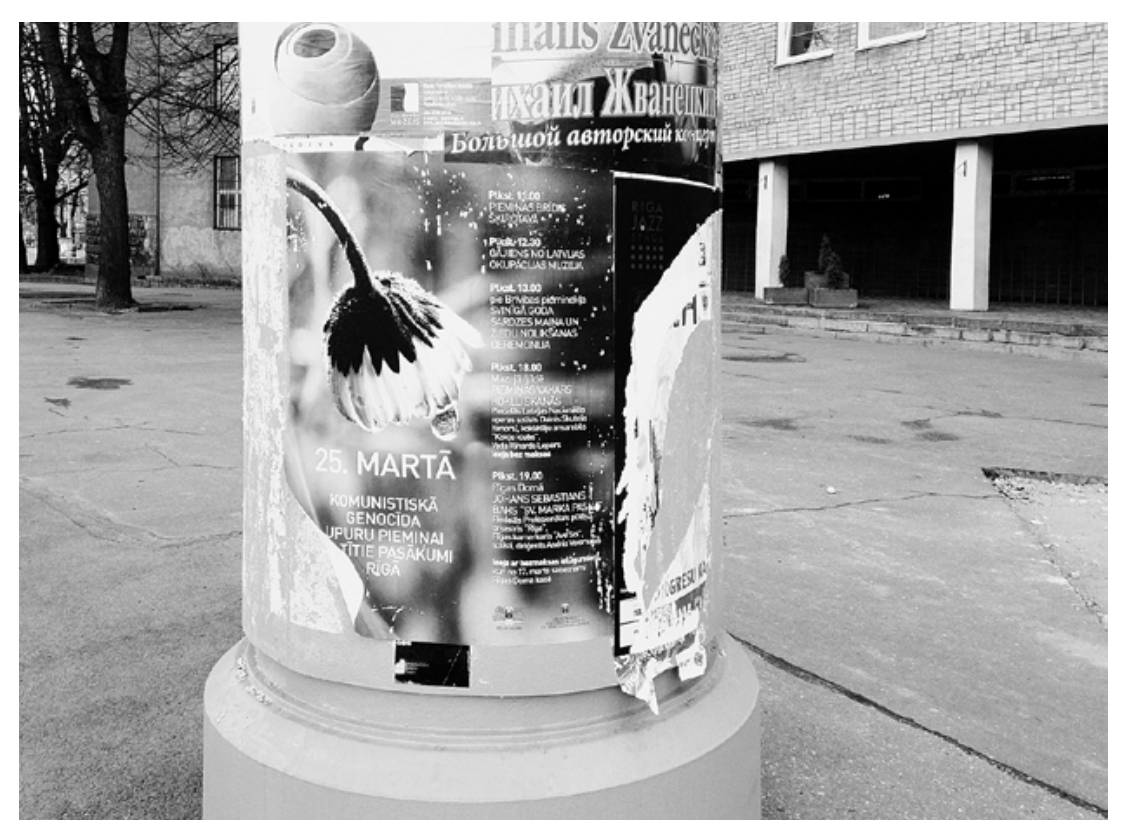

10. Latviešu leǵionāru pieminas dienas pasakums Lestenes brậ, kapos. 2015.gada 6. marts.
12. Rumbulas akcijā

nogalināto ebreju pie-

minail iedegtas svecites

pie Brivibas pieminekla 2016. gada 30. novembris
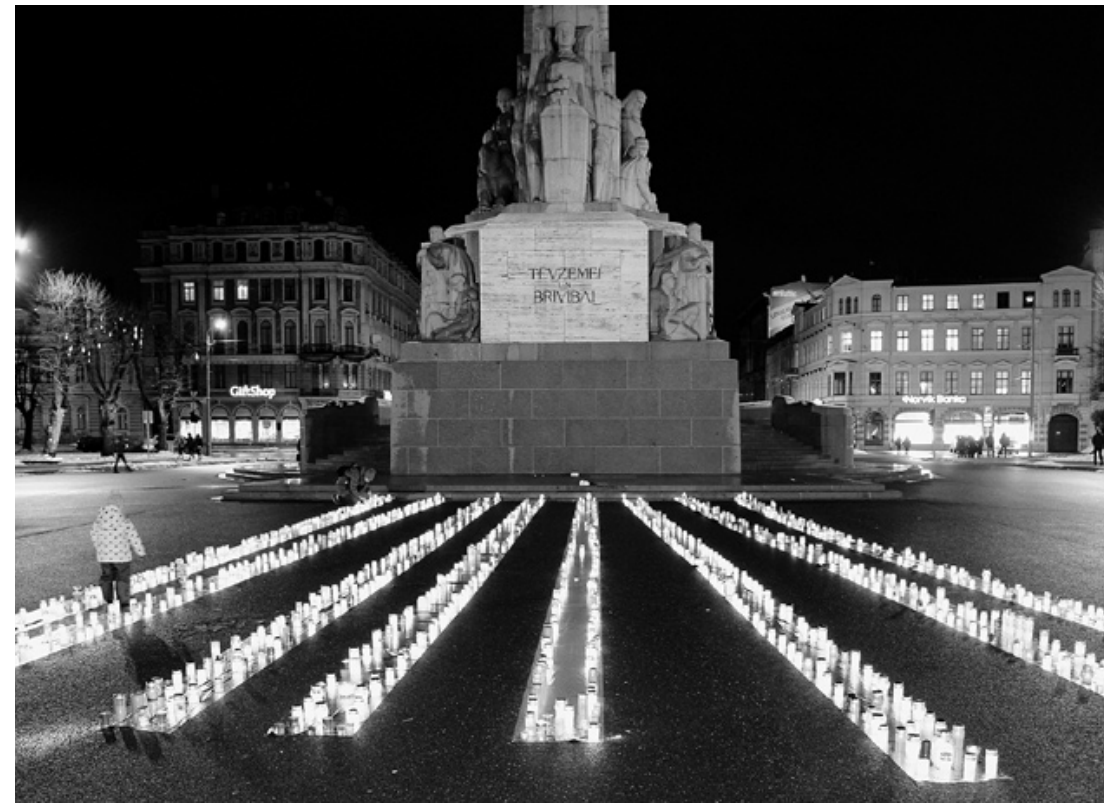
atcere savā vērienā ir pavisam neliela, tomēr tās galvenā nozīme ir solidaritātes uzturēšana represēto vidū un ar konkrēto lokālo kopienu un vietu. Visu šo pasākumu pamatrituāls ir atceres pasākums represiju upuru piemiṇas vietā un ziedu nolikšana (Delfi, 2017).

Socioloğisko aptauju dati liecina, ka pēdējos gados padomju masu deportāciju upuru atceres dienu atzīmē samērā nemainīgs skaits cilvēku. Pārsvarā tie ir gados vecāki ḷaudis, latvieši. 2016. gadā veiktās aptaujas rezultāti liecina, ka vecumgrupā 65-74 gadi 25. marta atceres norisēs piedalās vairāk nekā $21 \%$ aptaujāto, kamēr vecumgrupā 18-34 gadi šo pieminas dienu atzìmē 8-11\% respondentu un grupā 35-64 gadi-ap 14\%. Izteikta ir arī šā atceres pasākuma dalībnieku etniskā piederība - padomju deportāciju upurus piemin vairāk nekā $15 \%$ aptaujāto latviešu un mazāk nekā $5 \%$ krievu. Ir vērojama arī reğiionāla atšķirība, proporcionāli visvairāk cilvēku 25. marta atceres norisēs iesaistās Vidzemē (ap $20 \%$ ), vismazāk - Zemgalē (8,5\%), pārējos reǵionos - ap 12-14\%. Raugoties no izglìtibas viedokḷa, šì atceres diena ir nozīmīgāka cilvēkiem ar augstāko un vidējo izglìtỉbu, savukārt to neatzīmē l̦audis ar sākumskolas izglìtỉbu vai nepabeigtu pamatizglìtību. 25. martu piemin $35 \%$ aptaujāto zemnieku, $29 \%$ ilgstoši slimojošo un darba nespējigo invalīdu, $18 \%$ uzṇēmēju, $16 \%$ pensionāru, citās nodarbinātības grupās atzīmētāju skaits ir mazāks. Aptaujā iegūtie rezultāti par 14. jūnija padomju masu deportācijas dienas atceres dalībniekiem ir stipri lïdzịgi.

Komunistiskā režìma noziegumi tiek nosodīti arī 23. AUGUSTĀMolotova-Ribentropa PAKTA NOSLĒGŠAnAS DIENĀ. Šajā dienā tiek atzīmēta arī 1989. gadā notikušās akcijas «Baltijas ceḷ̌̌» gadadiena. 2014.gadā ar daudziem pasākumiem - velobraucienu, Facebook škirkḷ izveidi, konferenci, lekciju ciklu, piemiņas zīmi, grāmatas izdošanu, koncertu, speciāliem televizzijas un radio raidijumiem u. c. - tika svinēta «Baltijas cela» 25. gadadiena. Šo pasākumu rīkošanai bija pieškirts 280 ooo eiro atbalsts (LETA, 2014). 23. augusta atcerei ir mainīgi rituāli, no tiem izteiksmiggākie un noturīgākie ir ugunsrituāli-svecišu un ugunskuru dedzināšana. Notiek arī pasākumi ar «Baltijas ceḷa» vārdu, vairākus gadus norisinās draudzības skrējiens «Baltijas celš», kura maršruts ved cauri visām trim Baltijas valstīm.

Veikto aptauju dati liecina, ka šis atceres dienu atzīmētāju vidū ir dažādu paaudžu cilvēki, galvenokārt - latvieši. 2016. gadā 23. augustu pieminēja $11,1 \%$ izvaicāto latviešu un 2,8\% krievu. Vislielākais pasākumu dalībnieku skaits bija Vidzemē (19,4\%) un Rīgā (12,5\%), vismazākais Latgalē-2,6\%.

Pēdējos gados netiek rỉkoti publiski izteiksmigi komunistiskā režīma noziegumu un upuru pieminas pasākumi LATVIJAS OKUPĀCIJAS ATCERES DIENĀ 17. JŪNIJĀ Un PRET LATVIEŠU TAUTU VĒRSTĀ TOTALITĀRĀ KOMUNISTISKĀ REŽİMA GENOCİDA UPURU PIEMIN̦AS DIENĀ DECEMBRA PIRMAJĀ SVĒTDIENĀ. Neraugoties uz to, valsts karogu izkāršana pie mājām un šo noziegumu pieminējums medijos kalpo kā šo dienu atceres atgādinājums.

5. attēls. Molotova-Ribentropa pakta noslēgšanas dienas un «Baltijas ceḷa» atceres atzīmēšana 23. augustā (\%)

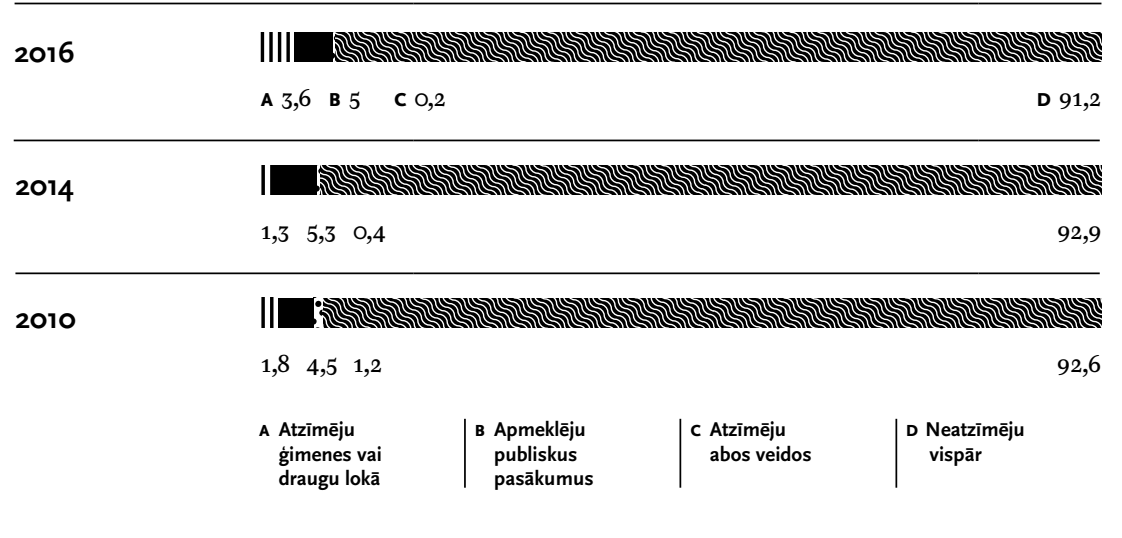

(Nacionālā identitāte 2010, 2014; SUSTINNO, 2016)

Piemiņas pasākumu trūkums dạẹeji skaidrojams ar to, ka nav šādu pasākumu rīkošanas iniciatīvas grupu, kurām būtu mērḳis ar šo atceres dienu pasākumiem proponēt totalitārisma nosodijjumu. Pret latviešu tautu vērstā totalitārā komunistiskā režìma genocīda upuru pieminas diena, kā jau minēts, valsts svētku un atceres dienu kalendārā tika iekḷauta pēc Austrumu Latviešu biedrības ierosmes. Pašreiz Latvijas publiskajā telpā nav vērojama tā dēvēto Krievijas latviešu nevalstisko organizāciju darbỉba, tostarp 20.gs. 3o. gados staliniskajā terorā nogalināto latviešu piemiṇas kopšana.

4. JŪLIJĀ - EBREJU TAUTAS GENOCİDA UPURU PIEMIN̦AS DIENĀLatvijā tiek pieminēti holokausta upuri. Šās dienas galvenais atceres rituāls notiek Rīgā pie memoriāla ebreju genocīda upuriem Gogoḷa ielā 25. Tajā piedalās valsts augstākās amatpersonas, ārvalstu diplomātiskā korpusa pārstāvji, ebreju nevalstiskās un reliĝ́iskās organizācijas. Pieminas pasākumi un ziedu nolikšana notiek arī citās holokausta upuru pieminas vietās Rỉgā un ārpus tās, tajos piedalās daži simti cilvēku. Biedrība Shamir kopš 2010.gada holokausta upuru piemiṇai 4.jūlijā (vai kādā citā dienā, kas tuva šai atcerei) rīko «Dzīvo gājienu» galvenajās bijušā Rīgas geto ielās, tā dalībniekus vieno sarkanas šalles, gājiena laikā tiek dziedātas dziesmas un aizdedzinātas svecìtes. Tajā regulāri piedalās ap 150 cilvēku. Ik gadus holokausta upuru atcere notiek arì dienās, kas nav oficiālajā valsts svētku, atceres un atzimeejjamo dienu kalendārā. To vidū nozīmīgs ir 1941. gada 3o. novembra un 8. decembra Rumbulas akcijā nogalināto ebreju piemiṇas pasākums ar valsts augstāko amatpersonu dalību. 2016. gada 3o. novembra vakarā pēc Žana Lipkes memoriāla direktores Lolitas Tomsones un vēsturnieka Kaspara Zella ierosmes pie 
Brivibas pieminekla notika svecīšu nolikšana, godinot holokausta upurus. Tajā piedalījās ap 300 cilvēku (LETA, 2017) Pasākuma dalībnieku pulcēšanā îpaša loma bija sociālajiem tìkliem. Šis notikums ir zimmigs ne tikai ar pilsonisko iniciatīvu un jauna atceres rituāla pieteikumu, bet arī ar holokausta upuru piemiṇas telpas paplašinājumu no holokausta memoriālajām vietām līdz nacionāli visnozīmīgākajai simboliskajai vietai - Brīvības pieminekḷ pakājei - un jaunu, līdz šim ar ebreju kopienu, holokausta piemiṇas kopšanu nesaistitu dalïbnieku ietveršanu.

Komunistiskā un nacistiskā totalitārā režīma upuru piemiņas dienām piederīgas ir arī Otrā pasaules kara upuru piemiņas dienas. Latvijas valsts svētku, atceres un atzīmējamo dienu kalendārā ir ieklauts 8. MAIJs, kurā vairuma Eiropas valstu tiek atzīmēta NACISMA SAGRĀVE UN PIEMINĒTI KARĀ BOJĀGĀJUŠIE. Oficiālo pamatrituālu veido svinīgais pasākums, kas notiek Rīgas Brāḷu kapos. Tajos, tāpa kā citos valstiski nozīmīgos pasākumos, piedalās valsts un Rỉgas pilsētas domes augstākās amatpersonas, ārvalstu diplomāti, Nacionālo bruṇoto spēku vienības, kā arī nevalstiskās organizācijas, kuru darbības lokā ir Otrā pasaules kara upuru piemina. Būtiski ir tas, ka šajā pasākumā kopš 2012. gada kopā ir cilvēki (vai viṇu pārstāvji), kuri kara laikā atradās frontes pretējās pusēs. ${ }^{2}$ Svinīgajā pasākumā reguJari iesaistas viešu strēlnieku korpusa un partizāṇu biedrības, Latviešu virsnieku apvienības, Latviešu Nacionālo karavīru biedrības prezidents Andris Bērzinš aicināja visus Latvijas kara veterānus kopigi pieminēt Otrā pasaules kara upurus 8. maijā Rīgas Brā̄lu kapos. Viñš šo aicinājumu izplatija 13o.latviešu strēlnieku korpusa veterānu biedribai, Latvijas Nacionālo karaviru apvienibai, Latviešu strēlnieku apvienibai, «Daugavas Vanagiem» u.c. kara veterānu un nevalstiskajān organizācijām. Aicinājumā uzsvērts - lai «8. maijs, kas Eiropā un ASV jau kopš 1945. gada tiek atzimèts kā Sabiedroto uzvaras pār nacionalsociälistisko Vầciju atceres diena, Latvijā netiktu izmantots sabiedribas grupu konfrontēšanai, bet gan veicinātu izligumu starp dažădās pusēs karojošajiem un visiem, kam šis dienas pieminešana ir nozimiga valsts augstākāans amatperronas un ārvalstuliplomāti Otrā pasaules kara upuru pieminu godināja b kara veterānu klāthūtnes (BNS, 2012).

un Latvijas ebreju kopienas pärstavji Ta rituala ipaši svari-

ga ir valsts augstāko amatpersonu sasveicināšanās un rokasspiediens kara dalībniekiem un vinuus pārstāvošo organizāciju biedriem. 8. maija rituāls ietver arì ekumenisko dievkalpojumu Rìgas Doma baznīcā, kā arī pasākumus ar amatpersonu klātbūtni Salaspils memoriālā un Lestenes brāḷ kapos, atcere norisinās arī reǵionos. 8. maijā atzìmētajai Nacisma sagrāves dienai un Otrā pasaules kara upuru pieminas dienas rituālam piemít integritātes raksturs, galveno vērību pievēršot totalitāro iekārtu nodarītajam ḷaunumam, netaisnīgumam pret tālaika sabiedrību, lỉdzjūtībai pret visām nelaikā zaudētajām dzīvỉbām, neškirirojot bojāgājušos pēc politiskās, etniskās, pilsoniskās vai reliğiskās piederības. Tāpat šiem svētkiem un valsts nostājai tajos ir svarīga politiskā nozīme pašreizējā situācijā, kad Krievijas polittehnologi velta lielus pūliṇus Latvijas (tāpat kā vairāku citu pēckomunistisko valstu) diskreditācijai, pozicionējot to kā valsti, kurā atdzimst nacisms/fašisms. 2016. gadā veiktās aptaujas dati rāda, ka Nacisma sagrāves

attēls. Nacisma sagrāves dienas un Otrā pasaules kara upuru piemiṇas dienas atzīmēšana 8. maijā (\%)

\begin{tabular}{|c|c|c|c|c|}
\hline \multirow[t]{2}{*}{2016} & \multicolumn{4}{|c|}{ 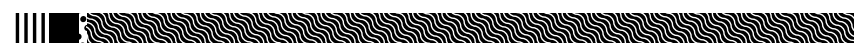 } \\
\hline & \multicolumn{3}{|c|}{ A 4,1 B 3,4 C 1} & D 91,6 \\
\hline \multirow[t]{2}{*}{2014} & \multicolumn{4}{|c|}{ 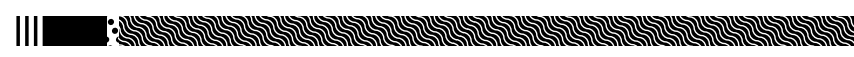 } \\
\hline & \multicolumn{3}{|c|}{$3,47,4 \quad 1,5$} & 87,3 \\
\hline \multirow[t]{3}{*}{2010} & \multicolumn{4}{|l|}{|||| $\mid\left[\quad::^{4}\right.$} \\
\hline & \multicolumn{3}{|l|}{$6,3 \quad 6,4 \quad 3,3$} & 83,9 \\
\hline & $\begin{array}{l}\text { A Atzīiēju } \\
\text { gimenes vai } \\
\text { draugu lokāa }\end{array}$ & \begin{tabular}{|l} 
| A Apmekleiju \\
publiskus \\
pasakkumus
\end{tabular} & $\mid \begin{array}{l}\text { C Atzīimēju } \\
\text { abos veidos }\end{array}$ & $\mid \begin{array}{l}\text { D Neatzīmēju } \\
\text { vispār }\end{array}$ \\
\hline
\end{tabular}

(Nacionālā identitāte 2010, 2014; SUSTINNO, 2016)

dienu un Otrā pasaules kara upuru piemiņas dienu atzīmē 8,4\% aptaujāto. Šis rādītājs ir visai tuvs citu komunistiskā un nacistiskā totalitārā režìma upuru piemiṇas dienu aktîvo dalībnieku skaitam. Tomēr, iespējams, ka šajā rādītājā dalẹji iekḷaujas arī tie Latvijas iedzīvotāji, kuri svin PSRS Uzvaras dienu. Politiskās partijas «Saskaṇa» satelītorganizācijas «9may.lv» rikotās Uzvaras dienas svinības jau vairākus gadus ilgst divas dienas - 8. un 9. maijā -, tādējādi arī tiecoties mazināt Nacisma sagrāves dienu un Otrā pasaules kara upuru piemiṇas dienas integratìvo un vēsturiskos pāridarỉjumus izlīdzinošo raksturu, kā arī relativizējot un attaisnojot Padomju Savienības totalitārā režima noziegumus.

Totalitāro režīmu nosodỉjums izskan arī valsts svētku, atceres un atzīmējamo dienu kalendārā neiekḷautajā LATVIEŠU LEĢ IONĀRU PIEMIṆAS DIENĀ 16. MARTĀ (skat. Zelče, 2011; Rozenšteine u.c., 2011). Rīgā šìs dienas pasākumu rituālu veido pieminas dievkalpojums, kas pēdējos gados notiek Sv. Jân, baznīcā, gājiens no baznīcas līdz Brīivibas piemineklim un ziedu nolikšana. Šā publiskā rituāla konsolidējošo un emocionālāko stīgu veido karogu ielejas izveidošana pie Brīvỉbas pieminekla, tā simboliski ietver un sargã gãjiena dalībniekus. Pēc Valsts policijas datiem, pēdējos gados Leǵionāru piemiṇas dienas gājienā piedalās 1000-2000 cilvēku. Vienlaikus gājiena maršruta ielas Vecrīgā un Brivibas pieminekḷa laukums pārvēršas par konfrontācijas vietu, jo 16. martā notiek arī pret Latviešu leǵionāru piemiņas dienu vērsti pasākumi, kuros tiek akcentēta latviešu leğionāru piederība vācu SS karaspēkam, latviešu iesaiste nacistiskā režìma noziegumos un propagandētā tēze par nacisma/fašisma atdzimšanu Latvijā. Tos rīko 


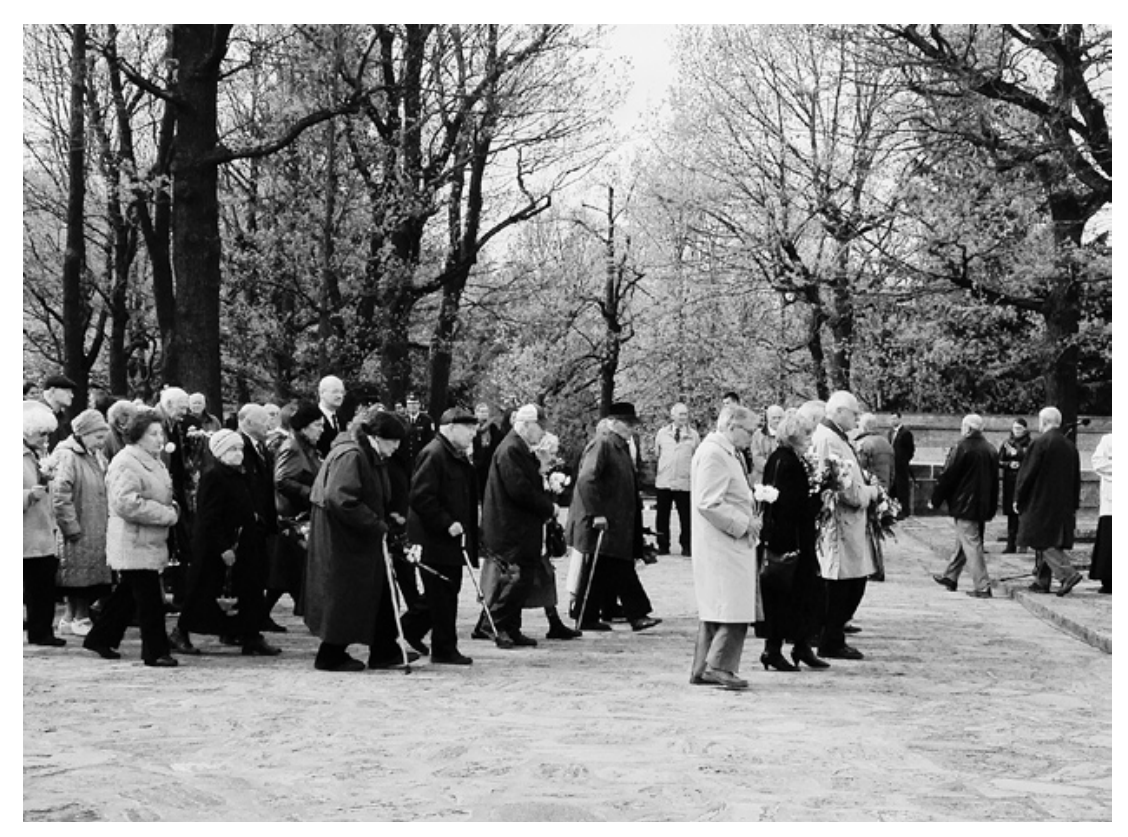

13. Otrā pasaules kara veterāni Nacisma pasaules kara upuru piemiñas dienas pasā2014. gada 8. maijs.

4. Latvijas Republikas Saeimas priekšsēdētāja Ināra Mūrniece, Latvijas Valsts prezidents Raimonds Vējonis, Latvijas Ministru prezidents Măris Kučinskis Nacisma sagrāeses dienas un Otra pasaules kara upuru pieminas dienas pasā-
kumā Rigas Brālu kapos. 2016. gada 8. maijs.
15. Padomju Savienibas uzvarai Otrajā pasaules karā veltitais floristikas objekts pie Uzvaras pieminekla. 2013.gada 9. maijs.

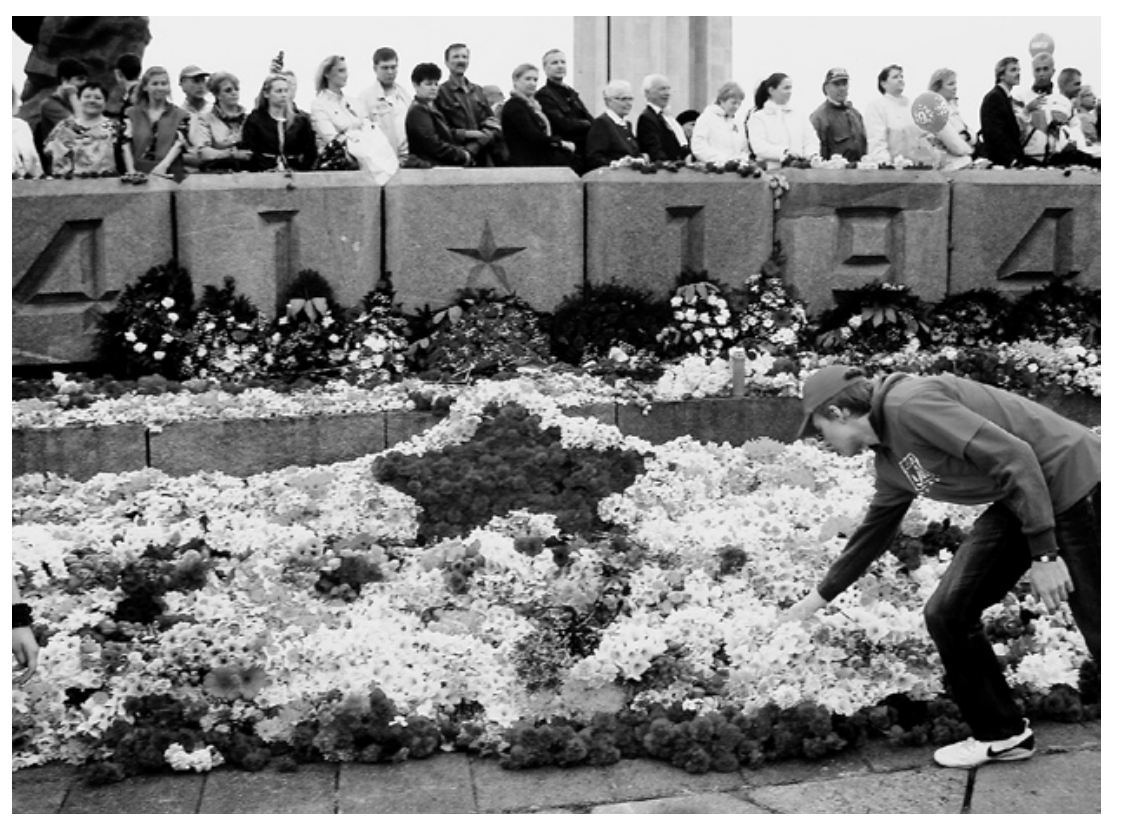

16. Padomju Savienïbas uzvaras Otrajā pasaules kara svinibas pie Uzvaras pieminekląa. 2017. gada 9. maijs.

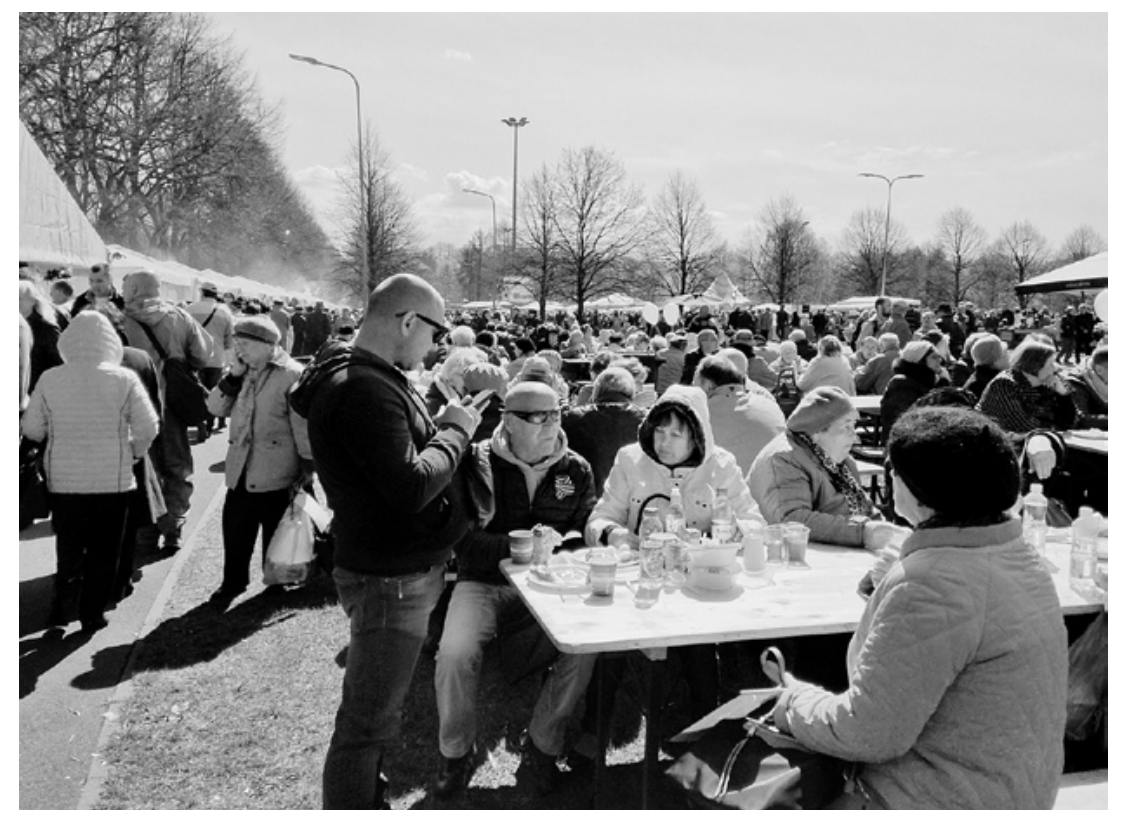


7. attēls. Latviešu leǵionāru piemiṇas dienas atzīmēšana 16. martā (\%)
2016

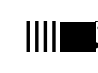

A 3,6 B 4,5 C 0,6

D 91,3

vietējās prokrieviskās organizācijas, kuru uzdevums, kā liecina žurnālistu pētījumi un Drošǐbas policijas sniegtā informācija, ir šḳelt Latvijas sabiedrïbu, diskreditēt valsti, uzturot jau minēto Krievijas mìtu par fašisma atdzimšanu, un tās saṇem finansējumu no Krievijas. Šo protestētāju uzdevums ir arī provocēt un pazemot gājiena dalībniekus, izjaukt svinīguma un pieminas atmosfēru, radìt agresīvu un konfrontāciju raisošu gaisotni. Vairākkārt tas arī ir izdevies. Piemēram, 2013. gadā to panāca ar skanuu tehniku, 2015. gadā par pasākuma efektīvāko notikumu kḷuva t.s. antifašistu veiktā performatīvā «brūnā mēra» dezinfekcijas akcija pie Brīivibas pieminekla. 16. martā Rīgā tiek īpaši domāts par drošỉbu un konfrontāciju nepiel̦aušanu, par šìs dienas vizuālo simbolu pārtapusi arī lielā policijas koncentrācija pilsētas centrā, policistu ḳēdes un nožogojuma barjeras. Valsts augstākās amatpersonas norobežojas no Leğionāru pieminas dienas, tās pasākumos nepiedalās arī valdỉbas locekḷi. Ja kāds no viṇiem to dara, tad-ministra amats jāatstāj (Gailāne u.c., 2017). Piemēram, 2014. gadā par piedalǐšanos 16. marta gãjienā pie Brīivibas pieminekḷa vides aizsardzības un reğionālās attīstības ministra amatu zaudēja Einārs Cilinskis (VL-TB/ LNNK) (Delfi, 2014).

Latviešu leğionāru piemiṇas diena tiek atzīmēta arī ārpus Rīgas. Īpaša simboliskā loma ir pasākumam Lestenes brālu kapos, kur joprojām tiek guldītas latviešu leğionāru atrastās mirstīgās atliekas. Kapsētā notiek svētbrīdis, ar runām uzstājas politiḳi, galvenokārt Nacionālās apvienības «Visu Latvijai! - Tēvzemei un Brīvībai/LNNK» un leğionārus pārstāvošo nevalstisko organizāciju lïderi, tiek nolikti ziedi. Katru gadu Lestenē pulcējas ap 1000 cilvēku. Leǵionāru piemiṇas dienas pasākumi turpinās Lestenes tautas namā. Savukārt Rīgā 2017. gadā Rīgas Latviešu biedrība piedāvāja koncertu.

Aptauju dati liecina, ka šo dienu atzìmē apmēram 10\% Latvijas iedzìvotāju, kara noslēguma «apalāās» jubilejas 2015. gadā nedaudz vairāk-nepiln 15\%. 2016. gada aptaujas datu analizze par Latviešu leğionāru piemiņas dienas atzīmētājiem rāda, ka dati ir samērā viendabịgi. Piemēram, vinuu vidū nav būtisku vecumgrupu atšķiriību - visās 7-10\%. Izṇēmums ir vecumgrupa 65-74 gadi-tajā no aptaujātajiem šajā atceres dienā iesaistās 14,8\%. Tāpat nav izteiktas izglìtības un nodarbošanās diferences. Reǵionālā griezumā Leĝ́ionāru pieminas dienu vairāk atzīmē Rīgā un Vidzemē. Izteiktākās ir šā atceres pasākuma dalībnieku sastāva etniskās atšḳirības. Atceres norisēs piedalās 11,1\% aptaujāto latviešu un 3,6\% krievu tautỉbas respondentu. Šĩ piemiṇas diena galvenokārt nozīmīga ir bijušajiem leğionāriem, vinu ğimenēm un draugu lokam.

Komunistiskā un nacistiskā totalitārā režìma upuru piemiṇas dienu galvenie pasākumi publiskajā telpā tiek atspoguloti plašsazinas līdzeklos, galvenokārt sabiedriskajos un reǵionālajos medijos, portālos un drukātajos laikrakstos, kas mēdz pirmās lapas titulbildēs atainot atceres pasākumu un/ vai tā simbolus. Informācija par piemiṇas dienām tiek iekḷauta ziṇu raidỉjumos, akcentējot amatpersonu piedalī̌šnos. Portāls delfi.lv 16. martā piedāvā Rỉgas notikumu teksta un video tiešraidi, visos lielākajos portālos tiek publicētas piemiṇas pasākumu fotogrāiiju galerijas. Salīdzinoši lielāka vērība no visām komunistiskā un nacistiskā totalitārā režìma upuru pieminas dienām masu medijos veltīta padomju masu deportāciju atcerei. Latvijas Televīijas programmās un Latvijas Radio ir speciālas pārraides, pēdējos gados šajās dienās LTV regulāri demonstrē režisores Dzintras Gekas dokumentālās filmas, kas veltītas represēto cilvēku un vinu bērnu likteniem. Latviešu leớionāru piemiṇas diena jau ilglaicīgi Latviju diskreditējošā formātā tiek prezentēta Krievijas plašsaziṇas līdzekḷos.

Lielākoties komunistiskā un nacistiskā totalitārā režìma upuru piemiṇas dienas atzīmē ap $10 \%$ vai mazāk Latvijas iedzivotāju, tikai 25 . marta atcerē iesaistās mazliet vairāk cilvēku. Vērojama arī tendence, ka šo piemiņas dienu atzīmētāju skaits nedaudz sarūk. Vairumā atceres pasākumu dominē izteikti standartizēts rituāls - mìtiňš, runas, ziedu nolikšana, dažreiz - gājiens, tādējādi šie atceres notikumi iemantojuši rutīnas dabu. Tomēr to regulārā norise un atspoguḷojums medijos kalpo kā atgādinājums par komunistiskā un nacistiskā totalitārā režìma noziegumiem, upuru piedzīvoto pāridarỉjumu un netaisnīgumu, kas uztur totalitārisma un noziegumu pret cilvēci nosodijuma diskursu.

No padomju laika mantotie svētki
Latvija no padomju okupācijas perioda ir mantojusi divus svētkus - Starptautisko sieviešu dienu 8. martā un Padomju 
Savienības Uzvaras dienu 9. maijā. Pirmā no tām kopš 2007.gada ir iekḷauta arī Latvijas valsts svētku, atceres un atzīmējamo dienu kalendārā.

Starptautiskā sieviešu diena bija vieni no vispopulārākajiem svētkiem vēlīnajā Padomju Savienībā. Kopš 1965.gada, kad tie iemantoja brīvdienas statusu, mainijās arī svētku diskurss un svinēšanas prakses. Sieviešu līdztiesības problēmu vietā par dominējošo svētku vēstijumu kḷuva sievietes lomas ǵimenē un darba kolektīvā, sievietības, kā arī mātes un vecmāminnas cildinājums. No politiskiem svētkiem tie pārtapa par privātiem svētkiem, kas tika svinēti ǵimenēs, nelielos kolektīvos pie svētku galdiem un skolās un bērnudārzos sirsnīgu sarīkojumu veidā. Šajos svētkos sievietes arī tika dāsni apdāvinātas, to obligātais rituāls - ziedu pasniegšana. Publiskajā telpā apzīmējumu Starptautiskā sieviešu diena nereti aizstāja/papildināja svētku nosaukumi-Pavasara un darba svētki, Mātes diena, G̦imenes svētki, Visas tautas svētki u.c. (Chaterjee, 2002; Yarskaya-Smirnova \& Karpova, 2003; Puzo, 2011). Padomju sieviešu diena klasificējama kā «spriedzes menedžmenta svētki», kuros risinājās karnevāla spēles - uz vienu dienu sieviete tika kronēta par sabiedrības/ valsts karalieni, savukārt vīrietim piešķirta vasaḷa loma. Neapšaubāmi, «sievietes nonākšana padomju 8. marta apvērstās pasaules centrā bija vienlaikus patiesās marginalizācijas zīme un arī marginalizēšanas līdzeklis» (Bula, 2008, 39.-40.lpp.). Totalitārā iekārtā nebija iespējams mainìt valstī pastāvošo sociālo kārtību, kurā oficiālā līmenii tika deklarēts, ka pastāv dzimumu līdztiesība, bet reālajā praksē šāda vienlīdzība neeksistēja nevienā dzīves jomā. Šì situācija arī lielā mērā iniciēja 8. marta dzimumu lomu mainas spēles un svinēšanas prieku un daudzveidīgos karnevāliskos formātus, kas arī sieviešu dienu darīja par īpašiem padomju sabiedrïbas svētkiem, kuros galvenais bija dzimumu attiecības, ğimene un atpūta.

Lai arī pēc Latvijas neatkarības atgūšanas sieviešu diena vairs nebija valsts svētku, atceres un atzīmējamo dienu kalendārā, to daudzi turpināja svinēt. LU Literatūras, folkloras un mākslas institūta un portāla delfi.lv 2017. gadā veiktā aptauja liecina, ka vien ap $10 \%$ respondentu pēc PSRS sabrukuma neatgriezeniski pārtrauca svinēt 8 . martu, bet $55 \%$ to turpināja svinēt, neraugoties uz brīvdienu un svētku statusa neesamību (Bula, 2017). Sieviešu diena bija/ir īpaši populāra Latvijas krievvalodīgajā sabiedrības dạ̣ā. Svinēšanas praksi palīdzēja uzturēt un attīstìt Krievijas mediju, it īpaši televizijas, lietojums, jo šajā valstĩ sieviešu dienai joprojām bija svētku, turklāt loti svinētu svētku statuss (Chaterjee, 2013). Turklāt svētku dienaskārtību papildināja populārās kultūras un komercializācijas intensīvā klātbūtne. Jāteic, ka Latvijas sociālajā kārtībā turpināja/turpina pastāvēt pietiekami augsts dzimumu nelīdztiesības līmenis, kas arī saglabāja šo svētku svinēšanas iekšējo ideoloğiju. Folkloriste Dace Bula norāda, ka 8. marta atgriešanos Latvijas valsts svētku kalendārā iespējams saistìt ar pielaidīgākas attieksmes pret padomju laiku diskursa veidošanos, kā arī tā vēsta par tradīiju noturìgumu
8. attēls. Starptautiskās sieviešu dienas atzīmēšana 8. martā (\%)

\begin{tabular}{|c|c|c|c|c|c|}
\hline \multirow[t]{2}{*}{2016} & \multicolumn{5}{|c|}{$\mid$} \\
\hline & \multicolumn{3}{|l|}{ A 65,8} & & D 22,4 \\
\hline \multirow[t]{2}{*}{2014} & \multicolumn{5}{|c|}{ |||||||||||||||||||||||||||||||||||||||||||||||||||||||||. } \\
\hline & \multicolumn{3}{|l|}{68,4} & $3,28,6$ & 18,9 \\
\hline \multirow[t]{3}{*}{2010} & \multicolumn{5}{|c|}{ 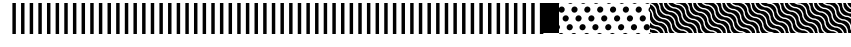 } \\
\hline & \multicolumn{2}{|l|}{62,8} & \multicolumn{2}{|c|}{$\begin{array}{ll}2,2 & 10,7\end{array}$} & 24,3 \\
\hline & $\begin{array}{l}\text { A Atzimmēiu } \\
\text { gimenes vai } \\
\text { draugu lokâ }\end{array}$ & \begin{tabular}{|l} 
| A Apmeklèiu \\
publiskus \\
pasăkumus
\end{tabular} & \begin{tabular}{|l} 
C Atzimejüu \\
abos veidos
\end{tabular} & & \\
\hline
\end{tabular}

(Nacionālā identitāte 2010, 2014; SUSTINNO, 2016)

un ilgtspēju. «Pusgadsimtu ilgā svinēšanas pieredze ir izrādỉjusies pārāka par svētku simbolisko un ideoloğisko saturu. Lai arī 8. marta semantika lielai daḷai cilvēku mūsdienu Latvijā ir nepieņemama kā feministiskajā, tā padomiskajā versijā, tomēr notiek laušanās svētku priekam,» atzīst D. Bula (2008, 27.-28.lpp.). Sieviešu dienas svinēšanas likumību pēdējos gados ippaši akcentē pilsētvides noformējums ar apsveikumiem 8. martā un informāciju par svētkiem veltìtajiem pasākumiem, preču un pakalpojumu reklāma ar atsaucēm uz sieviešu dienu, komercakcijas, kā arī šiem svētkiem veltītu raidỉjumu un publikāciju iekḷaušana nozīmīgākajos plašsaziṇas līdzekḷos. 8. martā ir arī nostiprinājusies jauna, atraktīva izklaidējošā tradīcija-Sieviešu dienas rallijs, 2017. gadā risinājās jau devitais rallijs. Vairākās pilsētās tiek rīkoti arī Sieviešu skrējieni.

Sociolog̣isko aptauju datu rezultāti vēsta, ka sieviešu dienu Latvijā atzìmē ap $80 \%$ aptaujāto, dominējošais formāts - svētki ǵ̛imenes un/ vai draugu lokā. Tā tos svin ap $65 \%$ respondentu. 8. martu atzīmē abi dzimumi-2016. gadā $78,3 \%$ no aptaujātajām sievietēm un $76,7 \%$ no vīriešiem. Tāpat šos svētkus par svinamu dienu atzīst visas vecumgrupas, lai gan visvairāk svinētāju ir vecumgrupā no 25 līdz 54 gadiem - ap 80-81\% respondentu. Šajā vecumgrupā arī pamatā ietilpst aktīvi nodarbinātie cilvēki un ǵimenes, kas audzina bērnus. Sieviešu dienas svētku modelis arī ir visatbilstīgākais ğimenes un darbavietu svētku rituāliem. Nedaudz mazāk šie svētki tiek atzīmēti vecumgrupās 18-24 gadi un 55-64 gadi-75\%. Savukārt vecumgrupā 6-74 gadi-70,1\%. Aplūkojot sieviešu dienas svinēšanu Latvijas reğionos, jāteic, ka tā vispopulārākā ir tieši Zemgalē un Latgalē, kur to atzìmē ap $88 \%$ no visiem respondentiem, savukārt Vidzemē to svin tikai $62,8 \%$. 
Atškirības vērojamas arī iedzīvotāju etniskā sastāva griezumā: sieviešu dienas svētkos iesaistās 71,7\% aptaujāto latviešu un 91,7\% krievu. Raugoties no iegūtās izglìtības lìmeṇa, salīdzinoši vairāk šo dienu atzīmē aptaujātie cilvēki ar bakalaura grādu (88\%) un ar sākumskolas izglìtību vai nepabeigtu pamatizglìtību $(81,8 \%)$, bet vismazāk - ar pamatizglìtỉbu (61\%) un doktora grādu $(60 \%)$. Savukārt, vērtējot no pamatnodarbošanās, sieviešu dienu vismazāk svin nestrādājošie un darbu aktivin nemeklējošie (59,1\%), skolēni un studenti (65,2\%) un pensionāri $(68,4 \%)$. Aptauju dati apstiprina, ka sieviešu diena padomju periodā iedibinātajā modelī ir populāri un plaši svi-
3 Starptautiskā viriešu diena daudzās pasaules valstis tiek atzimēta 19. novem 1999. gadā Trinidādā un Tobago.

Krievijas Federācijā kop 1993. gada 23. februāris ir Tevzemes aizstavju diena. is ir svētku brivdiena. bri. Pirmo reizi to svinēja 2002. gadā Valsts dome pienèma lemumu, ka 23. februnēti svētki, tajos svarīgs ir dzimumu atškirības uzsvērums, attiecību ğimenē un darba kolektīvā stiprināšana. Sieviešu dienas rituāli pārsvarā konsolidē sabiedrību un arī leg̛itimizē dzimumu nelīdztiesību kā sociālās kārtỉbas dalu. Savukārt sieviešu diskriminācijas problēma tiek aktualizēta citos pasākumos, piemēram, 21. janvārī notikušajā starptautiskajā akcijā-Sieviešu solidaritātes gājienā.

Pilnībā Latvijā nav izzudusi arī padomju perioda t. s. VĪRIEŠU DIENAS atzimēēana. ${ }^{3}$ Pēdējās Padomju Savienỉbas pastāvēšanas desmitgadēs iedibinājās tradīija 23. februārī-Padomju Armijas un Jūras Kara flotes dienā-darbavietās, izglitīibas iestādes, ğimenēs u. c. sveikt vïriešus un rïkot viniem veltītus sarīkojumus. ${ }^{4}$ «Viriešu diena» bija sava veida sieviešu dienas klons, kas iemiesoja tās ikdienas svētku praksē iedibinātos rituālus, tikai uzmanības centrā liekot vïriešus. Lai arī Latvijas medijos ir izskanējuši šìs dienas svinēšanas nosodījumi un skaidrojumi, ka 23. februāris ir Sarkanās armijas, kas īstenoja Latvijas okupāciju, svētku diena, joprojām tas tiek atzīmēts atsevišḳos uzṇēmumos un iestādēs (piemēram, ar svētku galdu), tirdzniecības un pakalpojumu iestādes šo «Vīriešu dienu» izmanto reklāmā, piedāvā īpašas atlaides un izstrādājumus (NRA, 2016; Antonevičs, 2018). Piemēram, 2016. gada 23. februārī Jēkabpils Gaḷas nams pircējiem piedāvāja īpaši dekorētas tortes ar uzrakstiem latviešu un krievu valodā: «Manam vïrietim», «23.februāris», «Sveicam!» (kopā ar trim sarkanām zvaigznēm (Jēkabpils Galas nams, 2016). Savukārt dziedātāja Samanta Tīna šajā dienā 2018. gadā ar sociālo tīklu starpniecỉbu aicināja sveikt visus Latvijas viriešus «Viriešu dienā» (skaties.lv, 2018).

Padomju Savienības Uzvaras svētru SVinības 9. MaIJā un to vēsture padomju un pēcpadomju periodā ir aplūkotas vairākos pētījumos (piemēram, skat. Zelče, 2011; Ločmele u.c., 2011; Cheskin, 2012; Zelče, 2018). Pašreizējās 9. maija svinēšanas prakses sākumi datējami ar 2008. gadu, kad darbỉbu sāka politisko partiju apvienības «Saskanas Centrs» (kopš 2010. gada - partija «Saskaṇa») satelītorganizācija «gmay.lv». Tās uzdevums bija Uzvaras svētku organizācija atbilstoši šĩs partijas interesēm. Vērtējot «gmay.lv» darbību vairāku gadu ilgumā, jāsecina - tās uzdevums bija mazināt šo svētku pret
Latviju tieši vērsto ideoloğiju, izkopt pasākumu izklaidējošo dimensiju un iekḷaut 9. maiju Latvijas politiskajā un kultūras telpā. To noteica «Saskanas Centra» (vēlāk «Saskaņas») stratēǵiskie mērḳi iegūt pie varas esošas politiskās partijas pozịcijas pašvaldỉbu un parlamenta limmenì, nevis atrasties opozịcijā, kā līdz šim bija darbojušās partijas, kas balstijāās uz lielākā vai mazākā opozīcijā esošā krievvalodīgo elektorāta balsīm. «9may.lv» aktivitātes ietvēra arī ziedojumu vākšanu kara veterānu atbalstam visa gada ilgumā, talkas padomju brālu kapos, veterānu apsveikšanu, informācijas par Otro pasaules karu izplatīšanu, Georga lentǐšu dalīšanu (lìdz 2013. gadam), kā arī 9. maija svinību praktisko organizēšanu un norises nodrošināšanu. Baltijas Pirmais televizijas (PBK) kanāls informatīvi atbalstīja/atbalsta «9may.lv» darbību, to dara arī citi Latvijas krievvalodīgo auditorijai adresētie mediji. Pirms Uzvaras dienas PBK nodrošina vērienīgu pasākuma reklāmu, kā arī Padomju Savienības/Krievijas uzvaras diženuma cildinājuma diskursa propagandu un tā ietvaros «Saskanas Centra» politiku veikuma un kopỉbas ar saviem vēlētājiem propagandu. Būtiska nozīme svētku atmosfēras un Padomju Savienības/Krievijas uzvaras cildinājumā ir Latvijā skatāmajiem Krievijas televīijas kanāliem, kuru dienaskārtību 9. maijā un tam tuvējās dienās pilnībā veido Uzvaras diena. Rỉgā «9.may.lv» praktiskās darbības rezultāti bija vērojami jau 2009. gadā. Rīgas galvenajā svētku laukumā-Uzvaras pieminekḷa tuvumātika izveidota jauna moderna skatuve, novietots lielais ekrāns, piedāvāta Maskavas svarīgāko svētu notikumu translācija, izveidota bagātīga un daudzveidīga koncerta programma, nodrošināta apsardze. Memoriāla karogkātos parādijjās uzvilkti Latvijas karogi. Izmainas svētku rituālā radīja arī Krievijas agresija. 2014. un 2015. gadā 9. maija rītā uz lielajiem ekrāniem vairs netranslēja Maskavā notiekošo militāro parādi, «gmay.lv» paziṇoja, ka svētku vietās netiks dalītas Georga lentîtes. Šie lēmumi Latvijā svinētos svētkus ārēji attālināja no Krievijā notiekošā Uzvaras dienas rituāla (sk. Zelče, 2018).

Uzvaras dienas Latvijā koncepcija tika formulēta Rīgas mēra Nila Ušakova runās. Kopš 2010. gada tajās tika veidots diskurss, ka bez Padomju Savienības uzvaras Otrajā pasaules karā nebūtu mūsdienu neatkarīgās Latvijas valsts (Orlov, 2010; Gertners, 2010). 2015. gada runā mērs uzsvēra, ka Uzvaras diena Latvijā ir «tautas svētki», jo tos nerīko valsts, bet gan «tauta», un ka š uzvara ir «ğimenu atminas» dala, ko nekad un nekādos apstākḷlos nedrīkst nodot» (MIX TV, 2015). Šis diskurss tika attīstīts arī 2016. un 2017. gada runās, kas jau pamišus izskanēja krievu un latviešu valodā (Ušakovs, 2016, 2017). Uzvaras diena ir arī nozīmīgs Krievijas politiskās ietekmes instruments. Pēdējos divos gados Latvijas publiskajā telpā parādās Drošỉbas policijas un žurnālistu pētījumos iegūtā informācija par Krievijas naudas ieplūšanu Uzvaras svētku un citu pasākumu organizācijā (Jemberga u.c., 2015; Drošības policija, 2016, 2017). Kopš 2015. gada Latvijā notiek Krievijā iedibinātais 9. maija rituāls «Nemirstigais pulks» (skat. polk.lv). 
9. attēls. Padomju Savienības uzvaras

Otrajā pasaules karā atzīmēšana 9. maijā (\%)

\begin{tabular}{|c|c|c|c|c|}
\hline \multirow[t]{2}{*}{2016} & \multicolumn{4}{|c|}{ IIIIIIII : : } \\
\hline & A $10,1 \quad$ B 6,9 & c 2,6 & & D 80,4 \\
\hline \multirow[t]{2}{*}{2015} & \multicolumn{4}{|l|}{ ||||||||||| } \\
\hline & 10,9 & 3,8 & & 74 \\
\hline \multirow[t]{2}{*}{2014} & \multicolumn{4}{|l|}{|||||||||||| $\mid$} \\
\hline & $13,6 \quad 13,3$ & 7,7 & & 65,3 \\
\hline \multirow[t]{3}{*}{2010} & \multicolumn{4}{|c|}{ |IIIIIII| I : } \\
\hline & $10,5 \quad 10,9$ & 8,9 & & 69,7 \\
\hline & $\begin{array}{l}\text { A Atzīmēju } \\
\text { ġimenes vai } \\
\text { draugu lokā }\end{array}$ & $\mid \begin{array}{l}\text { B Apmeklejiu } \\
\text { publiskus } \\
\text { pasākumus }\end{array}$ & $\begin{array}{l}\text { c Atzìmēeju } \\
\text { abos veidos }\end{array}$ & $\begin{array}{l}\text { D Neatzīmēju } \\
\text { vispār }\end{array}$ \\
\hline
\end{tabular}

(Nacionālā identitāte, 2010, 2014; SUSTINNO, 2015, 2016)

Kopumā Uzvaras svētkos dominē izklaide, priecāšanās un atpūta, sērošanai un komemorācijai faktiski tajos ir maza loma. Svētku būtiska sastāvdaḷa ir pikniks brīvā dabā. Laukumā pie monumenta pārtikas pakalpojumu uzṇēmumi piedāvā visplašāko èdienu, bezalkoholisku dzērienu un dažādu gardumu klāstu. Svètku dalībniekus vieno arī ierašanās svētkos ar ziediem un Georga lentītes piespraušana pie apg̛ērba. Ziedu nolikšana pie pieminekḷa, zālienā vai pie kādiem citiem objektiem - ieročiem, stendiem - ir rituāla obligāta dạ̣a. Dalībnieku apgéērbā arī ir sastopama Krievijas simbolika, piemēram, Krievijas karoga krāsas jakas, sporta tērpi ar uzrakstu Russia, T krekli ar Krievijas un PSRS simboliem, tiek izmantoti arī Padomju armijas un Krievijas armijas militāro formu elementicepures, laiviṇas, jostas, krekli. Svētku laukumā pie pieminekḷa iespējams ieraudzìt cilvēkus T kreklos ar Vladimira Putina attēlu. Paši pasākuma organizatori un brīvprātigie ir tērpti spilgtos T kreklos ar uzrakstu «9may. lv». Svētku dalībnieku vidū ir sastopami arī cilvēki ar piespraustu Latvijas sarkanbaltsarkanā karoga lentīti (vai tās kombināciju ar Georga lenti), T kreklos ar uzrakstiem «Latvija» un «Rīga». «gmay.lv» organizēto svinību iezīme ir arī vakara koncertu veidošana ar krievvalodīgajā auditorijā l’oti populāru mākslinieku uzstāšanos, pēdējos gados pie Uzvaras pieminekḷa uzstājušās rokgrupas Mashina vremeni, DDT, Chaif, Diāna Arbennina un grupa Nochnye snaipery, kā arī serbu mūzikịis un filmu režisors Emirs
Kusturica. Populāro mūziku priekšnesumu baudīšana klātesošajos rada savilnojuma un kopības sajūtu, ko vēl vairāk pastiprina koncertam sekojošais grandiozais salūts un neformālais pasākuma dalībnieku gājiens no Uzvaras laukuma pēc salūta. Svētku laukumā valda labs noskanojums, cilvēki ir priecīgi, smaida, sarunājas, dzied līdzi no skatuves skanošajām dziesmām, aplaudē. Uzvaras svētku svinēšanā Latvijā maz kas palicis no Padomju Latvijā kultivētajiem oficiālajiem rituāliem. Formā stingrā militārā un varas rituāla vietā stājies neformāls, komercializēts un populārās kultūras caurausts brīvdabas festivāls. Šajā formātā Uzvaras svētki perfekti pilda svētku svinētāju solidaritātes un kopịgu vērtību veidotāja rituāla un spriedzes menedžmenta svētku funkcijas.

Saskaṇā ar socioloğisko aptauju rezultātiem 9. maija svētkus Latvijā atzīmē ap $20-26 \%$ visu respondentu, kā arī ir vērojama svinētāju skaita samazināšanās. Pēc «9may.lv» datiem, Rīgā pie Uzvaras pieminekḷa 2015.gada 8. un 9. maijā pulcējās 220 ooo cilvēku, 2016. gadā-170 ooo, 2017. gadā - 120000 Aptauju dati liecina, ka svētku svinētāju vidū vērojama izteikta etniskā šḳir tne. 9. maiju 2016. gadā atzìmēja 9,1\% apjautāto latviešu un 40,7\% krievu. Visvairāk bija pārstāvētas vecumgrupas 55-64 gadi (28,3\% respondentu) un 65-74 gadi (26,1\%), bet vismazāk 18-24 gadi (11,8\%). Svinētāju vidū ir vērojams neliels sieviešu pārsvars $-18,9 \%$ apjautāto viriešu un $20,1 \%$ sieviešu. Raugoties no izglìtības viedokla, svētku svinētāju vidū salīdzinoši vairāk ir pārstāvēti cilvēki ar sākumskolas izglìtỉbu vai nepabeigtu pamatizglìitību (54,5\% respondentu ar šādu izglitìbu), padomju laikā iegūtu augstāko izglītību $(32,3 \%)$ un pamatizglìtību (26\%). Savukārt, aplūkojot 9. maija atzīmētāju nodarbošanos, nedaudz vairāk ir pārstāvēti nestrādājoši, tomēr darbu meklējoši laudis (31,7\%), pensionāri (28,3\%), ilgstoši slimojošie un darba nespējigie invalīdi $(23,8 \%)$, bet mazāk - skolēni un studenti $(11,6 \%)$ un zemnieki $(10 \%)$.

Abi no padomju laika mantotie svētki-Starptautiskā sieviešu diena un Uzvaras svētki -ir stabila Latvijas svētku prakses daḷa. Lai gan šiem svētkiem ir arī kopīgas iezīmes, tomēr tie ir visai atšķirīgi. Jāteic, ka Uzvaras svētku Latvijā atzīmēšanas ideologi un rïkotāji tiecas to diskursā palielināt šîs dienas kā privāto svētku nozìmi, tādējādi vēl dziḷāk iesaknojot 9. maiju to svinētāju ğimenes un identitātes vērtībās.

\section{Spriedzes}

menedžmenta svētki

Spriedzes menedžmenta svētki piedāvā ar atpūtas, izklaides un prieka emociju starpniecību stiprināt solidaritāti, attiecības un piederību kopienai. Latvijā dalai no šāda veidiem svētkiem ir brīvdienas statuss: Jaungada dienai 1. janvārī, Lieldienām, Līgo un Jāṇu dienai 23.24. jūnijā, Ziemassvētkiem 24.-26. decembrī un Vecgada dienai 31. decembrī. Atzīmējamo dienu sarakstā ir ǵimenēm adresētā Mātes diena un Tēva diena, 
10. attēls. Populārāko spriedzes menedžmenta svētku atzīmēšana 2016. gadā (\%)

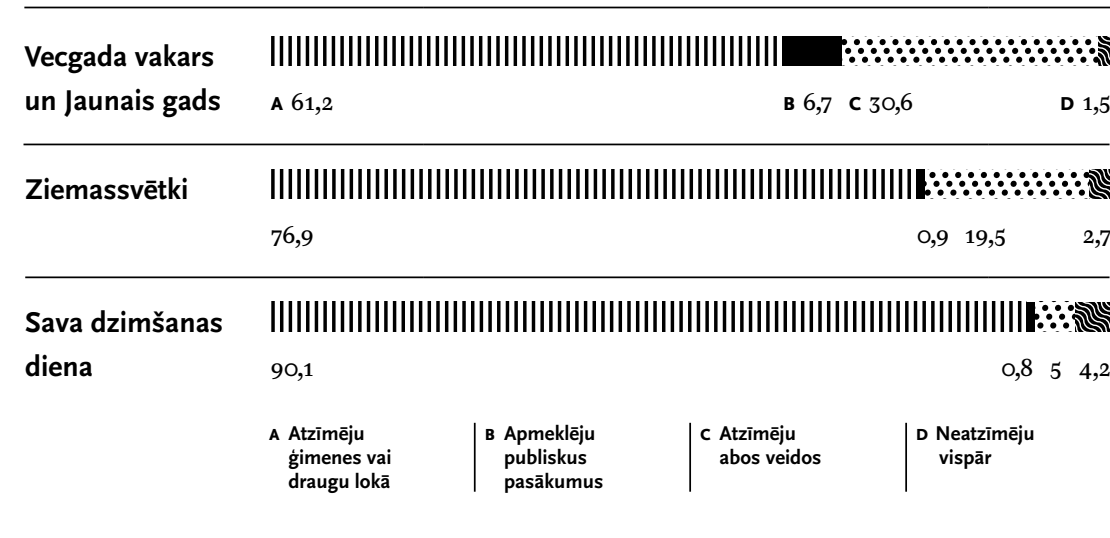

(SUSTINNO, 2016)

kā arī citi svētki. Tiek svinēti vēl daudzi citi spriedzes menedžmenta svētki, kas nav iekḷauti valsts svētku, atceres un atzīmējamo dienu kalendārā. Piemēram, pilsētu svētki, ielu un pagalmu svētki, sporta svētki, Muzeju nakts, Lielā talka, Helovīns, Sv. Valentina diena, arī dzimšanas un vārda dienas iekḷaujas šajā svētku grupā. Aptauju dati liecina, ka šo svētku norisēs labprāt iesaistās ḷoti daudzi cilvēki. 2017. gadā 51\% respondentu apliecināja, ka ir ieinteresēti piedalīties kādos vasaras laikā notiekošajos pilsētas svētkos, 35 \% plānoja doties uz Muzeju nakts pasākumiem (Kantar TNS, 2017a, 2017b). Savukārt Mātes dienas svinībām gatavojās 63\% aptaujāto un Tēva dienas - 29\% (Kantar TNS, 2017c, 2017d).

2016. gadā veiktās socioloğiskās aptaujas rezultāti vēsta, ka gandrīz vai visi valsts iedzīvotāji atzīmē Vecgada vakaru un Jaunā gada iestāšanos, Ziemassvētkus un savu dzimšanas dienu. Tāpat populāro svētku kategorijā ieklaujami Lìgo svētki un Jāni, ko atzīmē $96 \%$ aptaujāto (Kantar TNS, 2017e). Visi šie svētki galvenokārt tiek svinēti ğimenes un draugu lokā, tādējādi stiprinot saites tuvāko cilvēku un kopienas vidū. Tiem ir nozīme ǵimenu un kopienu veidošanā, tādējādi, raugoties no sabiedrības integritātes skatpunkta, šiem svētkiem ir dihotomiska daba. No vienas puses, tie sekmē robežu uzturēšanu starp sociālajām, etniskajām, religíiskajām u.c. kopienām un veicina to iekšējo solidaritāti. No otras puses, to svētku, kuriem ir starptautisks un/vai nacionāls mērogs, atzīmēšana lauj veidot saikni un solidaritāti ar citām kopienām, valsti un pasauli, apzināties savu piederību lielākām kopienām un vērtību sistēmai. Šo procesu arī sekmē mediji ar savu svētku intensīvo dienaskārtību (it īpaši ar svētku notikumu translācijām), svētkiem veltīto publisko pasākumu atvērtību, kā arī svētku komercializācija, kuras ietvaros radīitie vēstijumi tiecas uzrunāt visplašāko auditoriju un neievērot daudzās robežas.

\section{Noslēgums: anomijas \\ klātbūtne svētku un}

atceres dienu telpā

veidojošo loceklu identitätem, kuras, kă liecina nesenie pētījumi, raksturojamas kā daudzējādas, fragmentētas un bieži vien pretrunīgas. Tādējādi lielas dalas sabiedrïbas domāšana un dzīvesveids nav orientēts uz teritoriālo kopienu un tās vērtībām, kas arī ilustrē vājo proksimitāti valstij (Tabuns, 2014, 74.lpp.). Svētku svinēšana un komemorācija ir dzivesveida dala, kas identitāti gan veido/neveido, gan atspogulo. Dati par svētku un atceres dienu atzimēšanu ari lauj ieraudzìt Latvijas sabiedrības dezintegrācijas līnijas un diagnosticēt anomijas situācijas un/ vai to aizmetnus.

SVĒTKU UN ATCERES DIENU ETNISKĀ UN VALODAS TELPA Salïdzinot socioloğisko aptauju rezultātus par svētku un atceres dienu kultūru latviešu un krievu valodas telpā, redzams, ka starp tām pastāv būtiska atškirība. Jāteic, ka tai gan ir tendence pakāpeniski mazināties. Atškirību grafiskais atainojums vēsta, ka abas līnijas satuvinās tradicionālo spriedzes menedžmenta svētku dienās, savukārt attālinās Latvijas valsts un patriotiskos svētkos, kā totalitāro režīmu upuru pieminas un šo režimu nosodijuma dienās. Vēl viena raksturiezīme: krievvalodīgajā telpā proporcionāli vairāk tiek svinēti tie svētki, kas veido mantojumu no padomju okupācijas laika un tiek vērienīgi svinēti mūsdienu Krievijā - Starptautiskā sieviešu diena un PSRS Uzvaras diena. Netieši šie dati brïdina, ka dala Latvijas sabiedrības ar rituālu starpniecības vēlas uzturēt padomju un/vai Krievijas dzives kārtību un vērtības. Tie ar liek ieraudzìt anomijas situāciju, ko raksturo krievu valodas telpā dzivojošās sabiedrības dalas atsvešinātība no Latvijā valdošās sociālās kārtības, vērtībām un tai piederīgo identitātes pretrunīgumu vai pat krīzi (skat. 11. attēlu).

VECUMGRUPU SVĒTKU TELPA Socioloğisko aptauju rezultātu salīdzinājuma grafiskajā atainojumā ir iekḷautas trīs vecumgrupas: 18-24 gadi, 35-44 gadi un 65-74 gadi. Tas rāda, ka starp dažādām vecumgrupām piederīgo iesaisti svētkos un atceres dienu atzīmēšanā būtisku atškiriibu nav. Tomēr vērību pelna arī ne pārāk lielās diferences svarīgāko Latvijas valsts svētku atzīmēšanā starp gados jaunākajiem un vecākajiem ḷaudīm. Jau tika minēts, ka šo svētku menedžmentu ir uznēmušās valsts institūcijas, kas plāno un rỉko publiskos pasākumus un tiecas nodrošināt līdzdalïbu svētkos, 
11. attēls. Svētku svinēšana un atceres dienu

atzīmēšana latviešu un krievu valodas telpā (\%)

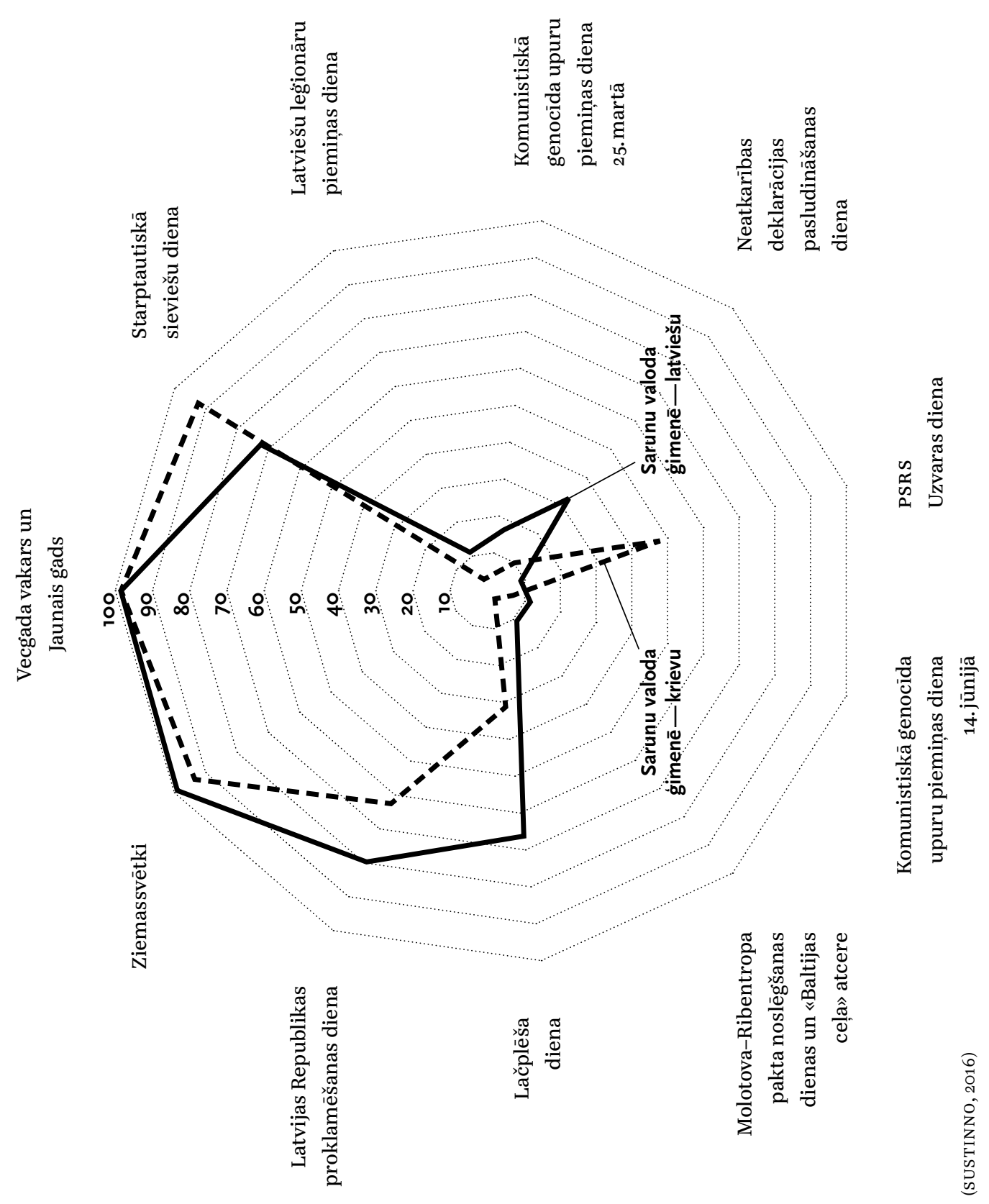

12. attēls. Svētku svinēšana un atceres dienu atzīmēšana vecumgrupu telpā (\%)
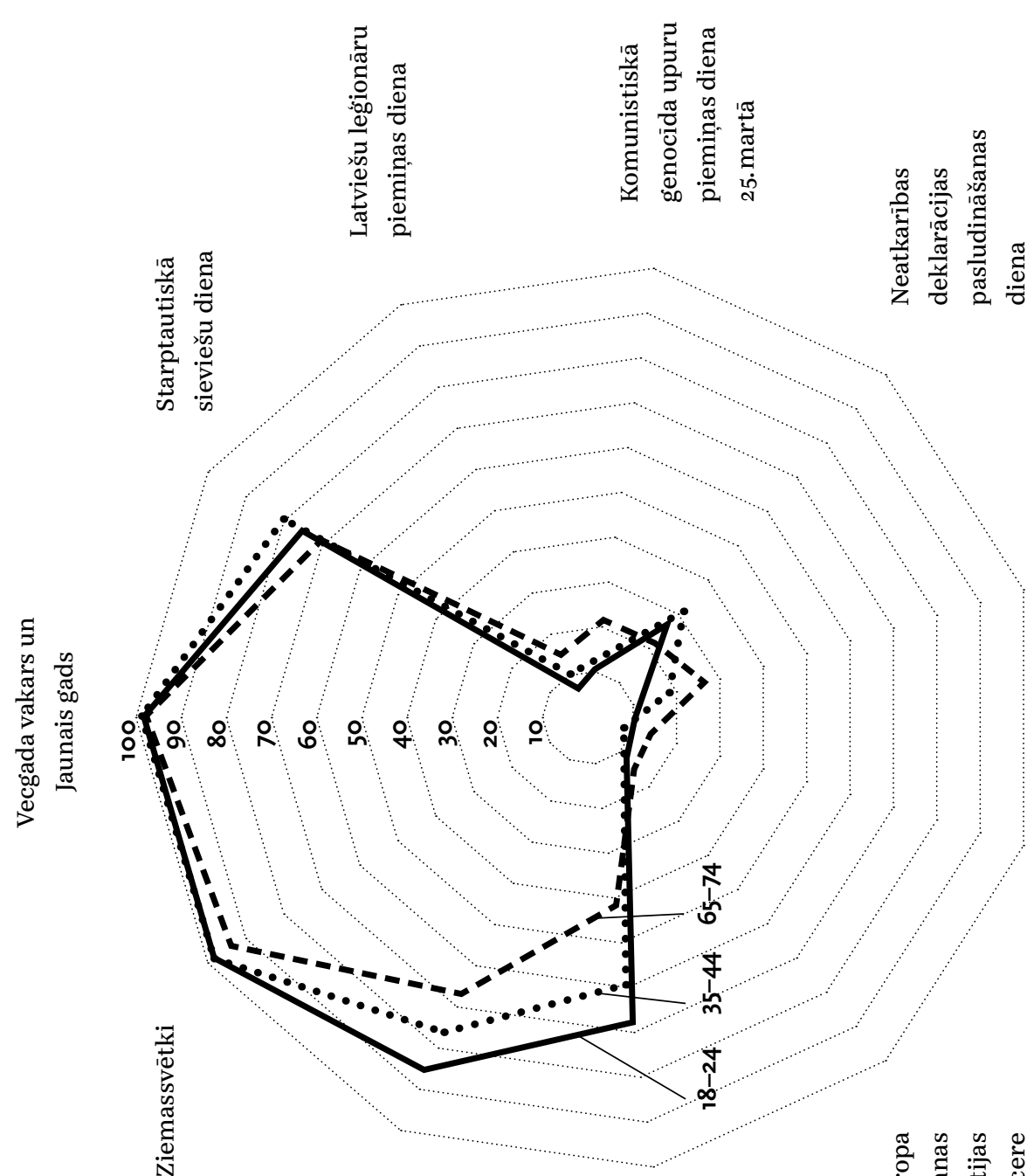

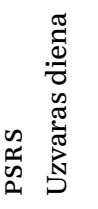

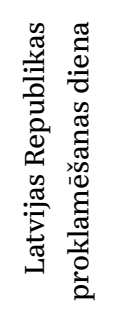

蛋

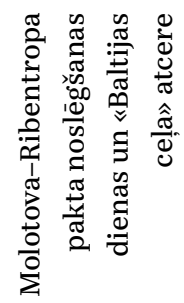


13. attēls. Svētku svinēšana un atceres dienu atzīmēšana izglìtības līmeṇa telpās (\%)

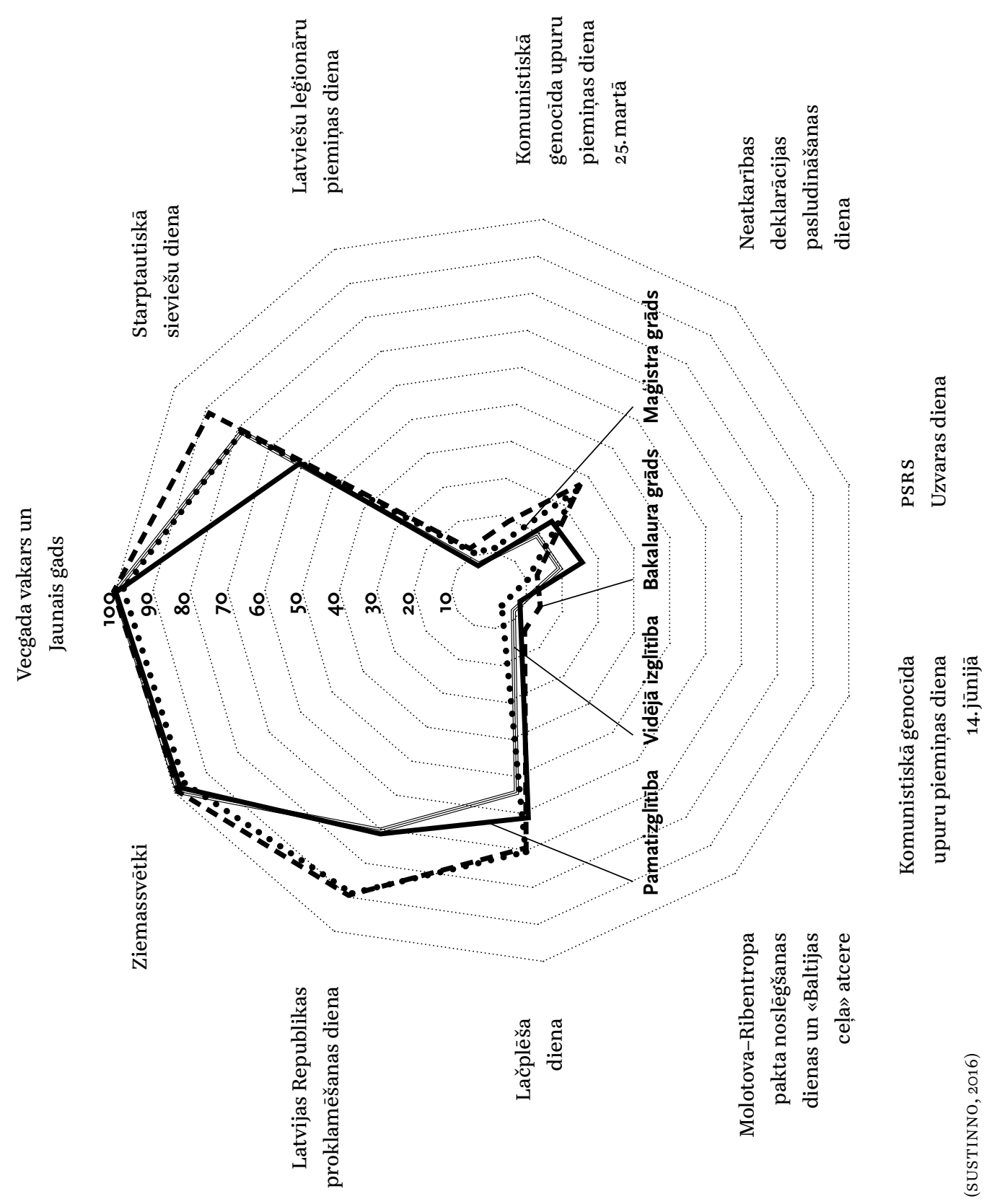

14. attēls. Svētku svinēšana un atceres dienu atzīmēšana nodarbošanās telpās (\%)

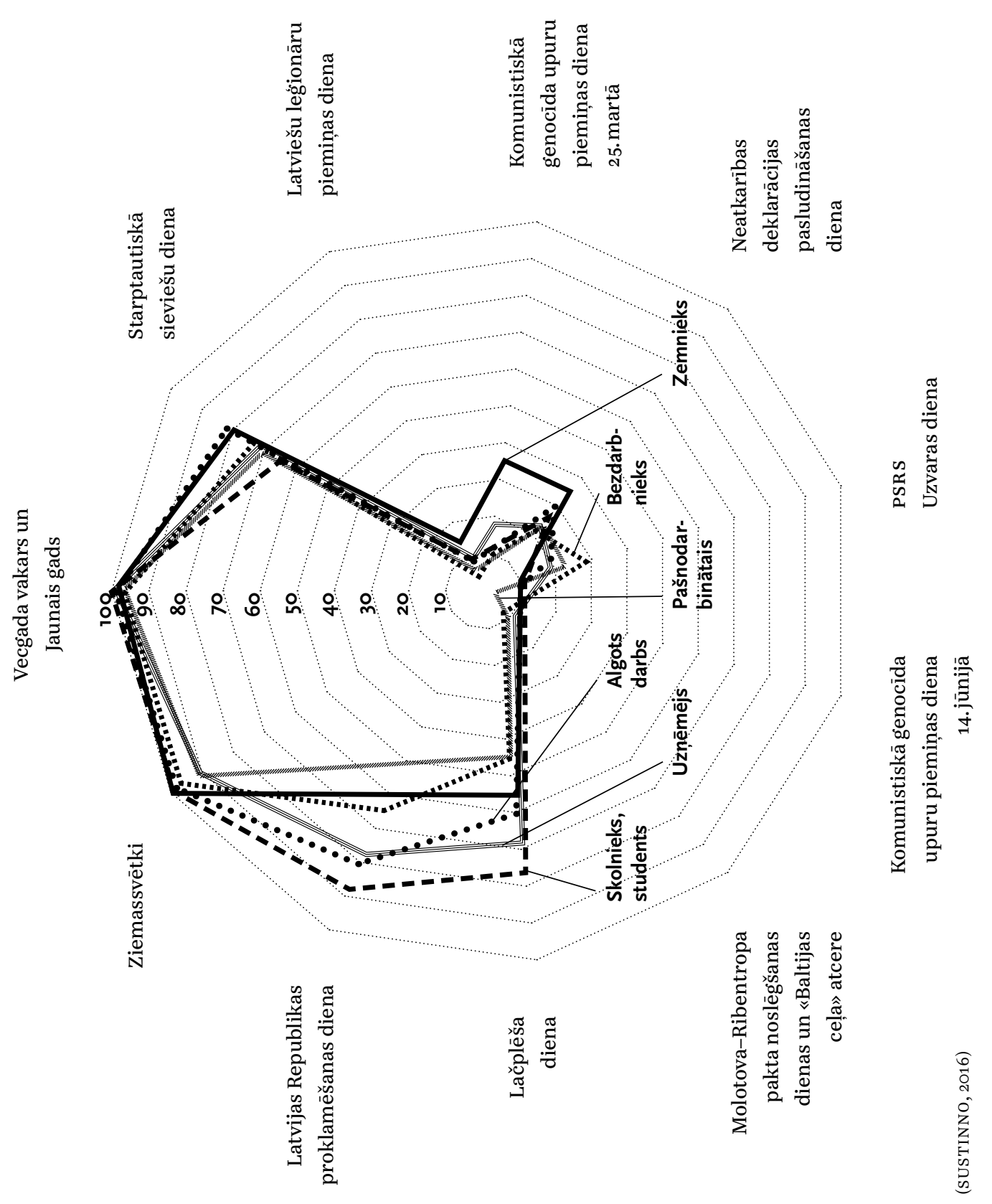


izmantojot modernās tehnolog̣ijas un digitālo vidi. Par valsts svētku organizācijas prioritāti tiek izvirzīta jaunatnes iesaiste. Tam kalpo arī uz šo vecuma grupu orientētu izklaides un kultūras pasākumu rỉkošana, bet tajos cilvēki, kuru vecums tuvojas 70 gadu slieksnim vai to pārsniedz, neredz savu vietu. Šie dati liecina, ka iezīmējas vecākās paaudzes atstumšana no valsts svētku svinēšanas, kas ietver arī anomijas riskus (skat. 12. attēlu).

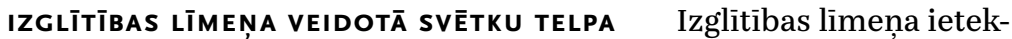
mes uz cilvēku dalību svētkos un komemorāciju raksturojumam ir izvēlētas vairākas bieži sastopamas izglitīibas grupas: sākumskolas izglitīiba/nepabeigta pamatizglìtỉba; pamatizglìtība; vispārējā vidējā izglìtỉba; profesionālais un akadēmiskais bakalaura grāds un profesionālais un akadēmiskais mağistra grāds. Socioloğisko aptauju datu grafiskais salïdzinājums rāda, kais visvairāk valsts svētku, atceres un atzīmējamu dienu norisēs iesaistās cilvēki ar bakalaura grādu. Vērojama arī atškirība starp augstāko izglìtību ieguvušo personu un cilvēku ar vidējo izglītỉbu un pamatizglitīibu svinēšanas un komemorācijas praksēm. Tomēr ìpaša uzmanība jāpievērš sociālajai grupai ar sākumskolas izglìtību un nepabeigtu pamatizglìtibu. Aptauju dati vēsta, ka šās grupas respondenti vispār nepiedalās padomju masu deportāciju upuru piemiṇai, Molotova-Ribentropa pakta noslēgšanas gadadienai un «Baltijas cela» atcerei, ka arī Latvijas neatkarỉbas atjaunošanai veltītos pasākumos. Viṇu iesaiste Lāčplēša dienas un Latvijas Republikas proklamācijas svētkos arī ir salïdzinoši maza. Savukārt tieši ḷaudis ar sākumskolas izglitiibu un nepabeigtu pamatizglìīibu proporcionāli visvairāk iesaistās PSR S Uzvaras dienas svinībās 9. maijā. Šîs sociālās grupas svētku svinēšanas un komemorācijas prakse demonstrē tās atsvešinātỉbu no valsts (iespējams, pat klaju opozīciju un naidīgumu pret to), tās politisko un sociālo distancēšanos no valsts un tās kultūras un vērtību telpas. Dati vēsta, ka šie mazizglìtotie cilvēki nejūtas piederīgi Latvijas valstij. Novērojamo situāciju var apzīmēt kā anomiju (skat. 13. attēlu).

PAMATNODARBOŠANĀS VEIDOTĀ SVĒTKU TELPA Aplūkojot socioloğisko aptauju datus no pamatnodarbošanās aspekta, jāsecina, ka svinēšanas un komemoratīvās prakses visai maz atškiras aktīvi nodarbināto grupu vidū. Problēmzonas iezīmējas sociāli vājāko grupu - bezdarbnieku, ilgstoši slimojošo un darba nespējigio invalīdu, pensionāru - iesaistē svētku, atceres un atzīmējamo dienu norisēs. Spilgtas tās ir šīm grupām piederīgo attiecībās ar Latvijas valsts un patriotiskajiem svētkiem. Arī šì situācija ietver anomijas iezimes (skat. 14. attēlu).

SVINEEŠANAS UN KOMEMORĀCIJAS KOPAINA Tai piemìt vairākas iezīmes. Pirmā - visplašāk svinētie valsts un patriotiskie svētki noris galvenokārt valsts paspārnē. Speciālas svētku menedžmenta institūcijas piedāvā koncepciju, programmu, organizē dažāda veida pasākumus un nodrošina finansējumu. Tādējādi vērojams valsts paternālisms par šīm svētku dienām, to pasākumiem un svētkiem veltìtajām kultūras norisēm un to veidotājiem. No vienas puses, tas garantē svētku norisi noteiktā kvalitātes līmenī, bet, no otras puses, bremzē valsts neatbalstito cilvēku un projektu dalïbu valsts svētkos un pilsoniskās iniciatīvas. Latvijas simtgades svētku rīkošana piedāvā lieliskas iespējas šìs situācijas zinātniskam monitoringam, lai izdarītu secinājumus par anomijas esamību/neesamību valsts un patriotisko svētku svinēšanas praksē.

Anomijas situācija ir samērā izteikta komunistiskā un nacistiskā totalitārā režìma upuru pieminas dienu kultūrā. Šo dienu atzīmēšanas norišu vērojums un sabiedrības iesaistes socioloğiskie mērỉjumi vēsta, ka šo režìmu nosodijumam un empātijai pret to upuriem nav liela nozīme mūsdienu sabiedrības lielas dalas locekḷu identitātē. Tādējādi ir iespējams runāt par morālo vērtību krizi un nepietiekamu demokrātiskas iekārtas priekšrocību izpratni, kas ietver risku, ka sabiedrība materiālās labklājỉbas, patērniecības un bezproblēmu dzìves vārdā var akceptēt autoritāru sociālo kārtību. Šìs anomijas esību apstiprina arī no padomju perioda mantoto svētku, tostarp arī Krievijas autoritārā režīma ideoloğijas cauraustā 9. maija, plašā atzimēšana.

Svētku svinēšanas un komemorācijas praksēs salīdzinoši maz ir vērojama privātā vai nevalstisko organizāciju iniciatīva un kreatīvi risinājumi, kas nepieciešami svinēšanas un atceres norišu lielākas publiskas rezonanses radī̌sanā un to morālo vēstījumu efektivitātes veicināšanā. Protams, ir izṇēmumi un labi piemēri.

Latvijas svētku, atceres un atzimējamo dienu kultūras atsevišķās jomās ir vērojama anomija, kas vēsta par pretrunām starp pastāvošo dziveskārtību un sociālo grupu un indivìdu identitātēm un vērtībām. 


\section{ANOMIJAS TĒMA UN TEORIJAS} SOCIĀLAJĀS ZINĀTNĒS

Alpert, H. (1939). Emile Durkheim and His Sociology. New York: Columbia University Press.

Atteslander, P., Granshow, B., \& Western, J. (Eds.) (1999). Comparative Anomie Research: Hidden Barriers - Hidden Potential for Social Development. Hantsfordshire: Asghate Publishing Ltd.

Berger, P. (1967). The Sacred Canopy. Elements of a Sociological Theory of Religion. New York, London, Toronto e.a.: Anchor Press.

Berger, P., \& Luckmann, T. (1966). The Social Construction of Reality. A Treatise in the Sociology of Knowledge. New York: Anchor.

Besnard, P. (1982). L'anomie dans la bibliographie intellectuelle de Durkheim. Sociologie et Sociétés, 14, pp. 44-53.

Dean, D. G. (1961). Alienation: Its Meaning and Measurement. American Sociologica Review, 26, pp. 753-758.

Durkheim, E. (1887) / Pickering, W. S. F. (1994). Review 'Guyau - L'Irréligion de l'avenir, étude de sociologie'. In W. S. F.Pickering (Ed.), Durkheim on Religion. Atlanta: Scholars Press.

Galtung, J. (1999). On the Epistemology of Anomie Studies: Some Comments. In P.Atteslander, B. Granshow, \& J.Western (Eds.), Comparative Anomie Research: Hidden Barriers - Hidden Potential for Social Development. Hantsfordshire: Asghate Publishing Ltd.

Giddens, A. (1971). Capitalism and Modern Social Theory. Cambridge: Cambridge University Press.

Halberstadt, M. (1955). On Solon's ‘Eunomia'. The Classical Weekly, 48(5), pp.197-203 Horton, J. (1964). The Dehumanization of of Anomie and Alienation. British Journal of Sociology, 15, pp. 283-300.

Levine, D. N. (1985). The Flight from Ambiquity: Essays in Social and Cultural Theory. Chicago: University of Chicago Press.

Lukes, S. (1971). Emile Durkheim: His Life and Work. Harmondsworth: Penguin. Marks, S. R. (1974). Durkheim's Theorie of Anomie. American Journal of Sociology, 80, pp. 329-363.

Mayo, E. (1933). The Human Problems of an Industrial Civilization. New York: Macmillan.

McClosky, H., \& Schaar, J.H. (1965). Psychological Dimensions of Anomy. American Sociological Review, 30 (1), pp. 14-40.

Merton, R. (1938). Social Structure and Anomie. American Sociological Review, 3(5), pp. 672-682.

Merton, R. (1964). Anomie, Anomia, and Social Interaction: Contexts of Deviant Behavior. In M. B. Clinard (Ed.),Anomie and Deviant Behavior (pp. 213-242). New York: Free Press. 
Merton, R. (1968). Social Theory and Social Structure. New York: Free Press.

Olsen, M. (1965). Durkheim's Two Concepts of Anomie. Sociological Quarterly, 6 ,

$$
\text { pp. 37-44. }
$$

Orrù, M. (1987). Anomie: History and Meanings. Winchester, Mass.: Allen \& Unwin. Ostwald, M. (1969). Nomos and the Beginnings of the Athenian Democracy. Oxford:

$$
\text { Clarendon. }
$$

Parsons, T. (1937). The Structure of Social Action. New York: MmcGraw-Hill.

Passas, N. (1995). Continuities in the Anomie Tradition. In F. Adler, \& Laufer, W.

(Eds.), The Legacy of Anomie Theory: Advances in Criminological Theory. Vol.6. New Brunswick, N.J.: Transaction.

Popper, K. (1998). The Open Society. Vol. 1. The Spell of Plato. Routledge.

Schmitt, C. (1950). Der Nomos der Erde im Völkerrecht des Jus Publicum Europaeum. Berlin: Duncker \& Humblot.

Seeman, M. (1959). On the Meaning of Alienation. American Sociological Review, 24(6), pp. $782-794$.

Srole, L. (1956). Social Intergration and Certain Corollaries: An Exploratory Study. American Sociological Review, 26, pp. 709-716.

Srole, L. (1965). Comment on Anomy. American Sociological Rewiew, 30(5), pp. $757-762$.

Teevan, J.J. (1975). On Measuring Anomia. Pacific Sociological Review, 18, pp. 159-170. Travis, R. (1993). The MOS Alienation Scale: an Alternative to Srole's Anomia Scale. Social Indicator Research, 28, pp. 71-91.

\section{GLOBĀLO VĒRTĪBU ORIENTĀCIJA} LATVIJAS IEDZĪVOTĀJU VIDŪ

Antonsich, M. (2009). National identities in the Age of Globalisation: The Case of Western Europe. National Identities, 11(3), pp. 281-299.

Appiah, K. A. (2006). Cosmopolitanism: Ethics in a World of Strangers. New York: W.W.Norton \& Co.

Ariely, G. (2016). Globalization and Global Identification: a Comparative Multilevel Analysis. National Identities. DoI:10.1080/14608944.2015.1136610.

Arnett, J.J. (2002). The Psychology of Globalization. American Psychologist, 57(10), pp. 774-783.

Beck, U. (2006). Cosmopolitan Vision. Cambridge: Polity.

Brett, J., \& Moran, A. (2011). Cosmpolitan Nationalism: Ordinary People Making Sense of Diversity. Nations and Nationalism, 17(1).

Calhoun, C. (2007). Nations Matter: Citizenship, Solidarity and the Cosmopolitan Dream. London: Routledge.

EC (2015). Special Eurobarometer «Climate Change» No. 435, May-June, 2015.

Ehrlich, P. A., \& Holdren, J.P. (1972). Closing Circle. Environment, 24, April.

Eurobarometer (2015). EU Development Cooperation and Aid. Special Eurobarometer, 441, November-December

Gaskova, M. (2014). Values Consciousness of the Russian Populace After the Collapse of the Soviet Union. Journal of Integral Theory and Practice, 9(11), pp.99-112.

Globescan (2002). International Environmental Monitor, 44. Toronto: Environics International.

Guibernau, M. (2001). Globalization and the Nation-State. In M.Guibernau, \& J.Hutchinson (Eds.), Understanding Nationalism (pp. 242-268). Cambridge Polity Press.

Held, D. et al. (1999). Global Transformations: Politics, Economics and Culture. Cambridge: Polity Press.

Hermans, H.J., \& Dimaggio, G. (2007). Self, Identity, and Globalization in Times of Uncertainty: A Dialogical Analysis. Review of General Psychology, 11(1), pp. 31-61.

Hobsbawm, E. (1992). Nations and Nationalism since 1780. New York, NY: Cambridge University Press.

Inglehart, R. (2008). Changing Values among Western Publics from 1970 to 2006. West European Politics, 31(1-2), January-March.

Inglehart, R. et al. (2000). World Values Surveys and European Values Surveys, 1981-1984, 1990-1993, and 1995-1997 data files.

ISSP Research Group (1998). International Social Survey Programme: National Identity I-ISSP 1995. GESIS Data Archive, Cologne. ZA2880 Data file version 1.o.o.

ISSP Research Group (2012). International Social Survey Programme: National Identity II - ISSP 2003. GESIS Data Archive, Cologne. ZA3910 Data file version 2.1.0. 
ISSP Research Group (2015). International Social Survey Programme: National Identity III - ISSP 2013. GESIS Data Archive, Cologne. ZA5950 Data file Version 2.0.0.

ung, J. K. (2008). Growing Supranational Identities in a Globalising World? A Multilevel Analysis of the World Values Surveys. European Journal of Political Research, 47(5), pp. 578-609.

Kinnvall, C. (2004). Globalization and Religious Nationalism: Self, Identity, and the Search for Ontological Security. Political Psychology, 25(5), pp. 741-767.

Lakner, C., \& Milanovic, B. (2013). Global Income Distribution: From the Fall of the Berlin Wall to the Great Recession. World Bank Policy Research Working Papers. December. Retrieved 25.08.2017 from https://elibrary.worldbank.org/ doi/abs/10.1596/1813-9450-6719.

Leiserowitz, R. et al. (2004). Sustainability Values, Attitudes and Behaviors: A Review of Multi-national and Global Trends. CID Working Paper No.113, Cambridge, MA: Science, Environment and Development Group, Center for International Development, Harvard Universit. Retrieved 24.08.2017 from http://www.cid. harvard. edu/cidwp/113.htm.

Mau, S., Mewes, J., \& Zimmermann, A. (2008). Cosmopolitan Attitudes through Transnational Social Practices? Global Networks, 8(1), 1-24.

Micheletti, M. (2003). Political Virtue and Shopping. Individuals, Consumerism, and Collective Action. Palgrave Macmillan.

Norris, P., \& Inglehart, R. (2009). Cosmopolitan Communications: Cultural Diversity in a Globalized World. New York: Cambridge University Press.

OECD (2003). Public Opinion and the Fight Against Poverty. Paris: OECD Development Centre.

Organisation of Economic Cooperation and Development (OECD) (2005). Official Development Assistance Increases Further - But 2006 Targets Still a Challenge. Paris. Retrieved 20.08.2017 from http://www.oecd.org/document/ 3/o,2340,en_2649_34447_34700611_1_1_1_1,oo.html.

Pew Research Center for the People \& the Press (2004). The Pew Global Attitudes Project Dataset. Washington, DC: The Pew Research Center for the People \& the Press.

Program on International Policy Attitudes (PIPA) (2001). Americans on Foreign Aid and World Hunger: A Study of U. S. Public Attitudes. Washington, DC: PIP. Retrieved 20.08.2017 from http://www.pipa.org/OnlineReports/BFW.

Raskin, P. et al. (2002). Great Transition: The Promise and Lure of the Times Ahead. Boston: Stockholm Environment Institute.

Schwartz, S. (2003). A Proposal for Measuring Value Orientations across Nations. Retrieved 01.08.2017 from http://www.europeansocialsurvey. org/docs/methodology/core_ess_questionnaire/ESS_core_questio nnaire_human_values.pdf.

Snider, J. S., Reysen, S., \& Katzarska-Miller, I. (2013). How We Frame the message of Globalization Matters. Journal of Applied Social Psychology, 43(8), pp. 1599-1607.
SUSTINNO (2015). Datafile. Research Program «Social Value Orientations and Social Regeneration", Latvia.

UNESCO (2014). Global Citizenship Education: Preparing learners for the challenges of the 21st century.

U.S. National Research Council (1999). Policy Division, Board on Sustainable Development, Our Common Journey: A Transition toward Sustainability Washington, DC: National Academy Press.

World Values Survey (2003). The 1999-2002 Values Surveys Integrated Data file. 


\section{POLITISKĀ ATSVEŠINĀTİBA UN} NOMIJA MŪSDIENU LATVIJĀ

Abbott, P., \& Wallace, C. (2012). Satisfaction and Societal Quality in Kazakhstan. In H. Selin, \& G. Davey (Eds.), Happiness across Cultures: Views of Happiness and Quality of Life in Nonwestern Cultures (pp.107-120). Netherlands: Springer. Acevedo, G.A. (2005). Turning Anomie on its Head: Fatalism as Durkheim's Concealed and Multidimensional Alienation Theory. Sociological Theory, pp. 75-85.

Almond, G., \& Verba, S. (1989). The Civic Culture Revisited:An Analytical Study. Thousand Oaks, CA: Sage Publications.

BISS (2005). Pilsoniskās sabiedrības veidošanās Latvijas lielākajās pilsētās un etniski neviendabīgajos rajonos Latvijā. Rīga: BISS.

Bobbio, N., \& Bellamy, R. (1987). The Future of Democracy. Cambridge: Polity Press. Bowler, S., \& Donovan, T. (2002). Democracy, Institutions and Attitudes about

Citizen Influence on Government. British Journal of Political Science, 32(2), pp. 371-90.

Brehm, J., \& Rahn, W. (1997). Individual - Level Evidence for the Causes and Consequences of Social Capital. American Journal of Political Science, 41(3), pp. 999-1023.

Buckley, C. (1997). Suicide in Post-Soviet Kazakhstan: Role Stress, Age, and Gender. Central Asian Survey, 16(1), pp. 45-52. DOI:10.1080/02634939708400968

Bullen, P., \& Onyx, J. (2000). Measuring Social Capital in Five Communities in NSw. Journal of Applied Behavior Science, 36(1), pp. 23-42.

Campbell, A., Gurin, G., \& Miller, W.E. (1971). The Voter Decides. Westport, Conn: Greenwood Press.

Catterberg, G., \& Moreno, A. (2006). The Individual Bases of Political Trust: Trends in New and Established Democracies. International Journal of Public Opinion Research, 18(1), pp. 31-48.

Coleman, J. (1990). Foundations of Social Theory. Cambridge, MA: Belknap Press of Harward University Press.

Dalton, R. (2004). Democratic Challenges, Democratic Choices: the Erosion of Political Support in Advanced Industrial Democracies. New York, NY: Oxford University Press.

Dean, D.G. (1961). Alienation: its Meaning and Measurement. American Sociological Review, pp. 753-758

DiRenzo, G. (1990). Socialization for Citizenship in Modern Democratic Society. In O. Ichilov (Ed.), Political Socialization, Citizenship Education, and Democracy (pp. 25-46). New York, NY: Teachers College Press.

Durkheim, E. (1983). Der Selbstmord. Frankfurt am Main: Suhrkamp.

Grootaert, C. (1998). Social Capital: The Missing Link? SCI Working Paper 3. Retrieved from http://siteresources.worldbank.org/INTSOCIALCAPITAL/ Resources/Social-Capital-Initiative-Working-Paper-Series/SCI-WPS-o3.pdf
Fox, J. (2006). Teacher's Corner: Structural Equation Modeling with the Sem Package in R. Structural Equation Modeling, 13(3), pp. 465-486.

Franke, S. (2005). Measurement of Social Capital: Reference Document for Public Policy Research, Development, and Evaluation. Toronto: Policy Research Initiative. Retrieved from http://policyresearch.gc.ca/doclib/ Measurement E.pdf

Fukuyama, F. (1996). Trust: The Social Virtues and the Creation of Prosperity. New York, NY: Free Press.

Fukuyama, F. (2001). Social Capital, Civil Society and Development. Third World Quarterly, 22(1), pp.7-20.

Hamilton, K. (2006). Where is the Wealth of Nations?: Measuring Capital for the 21st Century. Washington, DC: The World Bank. Retrieved from http:// siteresources.worldbank.org/INTEEI/214578-1110886258964/20748034/All.

Henn, M., Weinstein, M. \& Wring, D. (2002). A Generation Apart? Youth and Political Participation in Britain. British Journal of Politics and International Relations, 2(4), pp.167-192.

Horton, J. (1964). The Dehumanization of Anomie and Alienation: a Problem in the Ideology of Sociology. The British Journal of Sociology, 15(4), pp. 283-300.

Howard, M. (2006). The Leninist Legacy Revisited. In S. Koniordos (Ed.), World Order after Leninism (pp. 243-278). Seattle, WA: University of Washington Press.

Inglehart, R. (1990). Culture Shift in Advanced Industrial Society. Princeton, NJ: Princeton University Press.

Inglehart, R. (1997). Modernization and Postmodernization: Cultural,

Economic, and Political Change in 43 societies. Princeton, NJ: Princeton University Press.

Inglehart, R. (1999). Postmodernization Erodes Respect for Authority, but Increases Support for Democracy. In P. Norris (Ed.), Critical Citizens: Global Support for Democratic Government (pp. 236-256). New York, NY: Oxford University Press.

Inglehart, R. (2006). East European Value Systems in Global Perspective. In H. Klingemann, D. Fuchs, \& J.Zielonka (Eds.), Democracy and Political Culture in Eastern Europe (pp. 67-84). New York, NY: Routledge.

Inglehart, R., \& Flanagan, S. C. (1987). Value Change in Industrial Societies. American Political Science Review, 81(4), pp.1289-1319.

Ijabs, I. (2007). Pilsoniskā sabiedrība Latvijā: nākotnes perspektīvas. In Ozolina, Ž., \& Ulnicāne-Ozolina, I. (red.), Latvija 2020. Nākotnes izaicinājumi sabiedrība un valstij (141.-154.lpp.). Rỉga: LU Akadēmiskais apgāds.

Jennings, M. K. \& Stoker, L. (2004). Social Trust and Civic Engagement Across Time and Generations. Acta Politica, (39)4, pp. 342-379.

Jowitt, K. (1992). New World Disorder: The Leninist Extinction. Berkley, CA: University of California Press. 
Kim, I. (2005). A Sense of Alienation towards Government - an Analytic Framework. International Review of Public Administration, 9(2), pp. 55-64.

Knack, S. (2002). Social Capital and the Quality of Government: Evidence from the States. American Journal of Political Science, 46(4), pp. 772-85.

Koroleva, I., \& Rungule, R. (2006). Latvia: Democracy as an Abstract Value. In

H. Klingemann, D. Fuchs, \& J.Zielonka (Eds.), Democracy and Political Culture in Eastern Europe (pp. 25-66). New York, NY: Routledge.

Korzeniowski, K. (1994). Political Alienation in Poland in Days of Systemic Transformation. Polish Psychological Bulletin, (25)3, pp. 187-200.

Kovacheva, S. (2005). Will Youth Rejuvenate the Patterns of Political Participation? In J.Forbig (Ed.), RevisitingYouth Political Participation (pp. 19-28). Strasbourg: Council of Europe Publishing.

Krishna, A., \& Uphoff, N. (1999). Mapping and Measuring Social Capital: A Conceptual and Empirical Study of Collective Action for Conserving and Developing Watersheds in Rajasthan, India. Social Capital Initiative Working Paper, 13.

Krivosheev, V. (2004). Osobennosti anomii v sovremennom rossiyskom obshchestve [Peculiarities of Anomie in the Contemporary Russian Society] Sotsiologicheskie issledovaniya, 3, 5. 93-97 (in Russian).

Lagerspetz, M. (2009). Still Citizen vs. State? Post-communist Prospects for Democracy in Europe. In A. Konttinen (Ed.), Civic Mind and Good Citizenship (pp. 147-68). Tampere: University of Tampere.

Legge, S., Davidov, E., \& Schmidt, P. (2008). Anomia: Empirical Analyses of the Leve and Development of the Individual Experience of Anomie in the German Population. International Journal on Conflict and Violence, 2(2).

Lytkina, E. I. (2015). Anomie and Alienation in the Post-communist Area: A Rreapplication of the Middleton Scale in Russia and Kazakhstan. Higher School of Economics Research Paper No. WP BRP, 32.

MacIver, R. M. (1950). The Ramparts We Guard. Macmillan.

Mc Dill, E. L., \& Ridley, J.C. (1962). Status, Anomia, Political Alienation, and Political Participation. American Journal of Sociology, pp. 205-213.

Mierina, I. (2014). Political Alienation and Government-Society Relations in Postcommunist Countries. Polish Sociological Review, 185(1), pp. 3-24.

Mierina, I. \& Cers, E. (2015). Is Communism to Blame for Political Disenchantment in Post-Communist Countries? Cohort Analysis of Adults Political Attitudes. Europe-Asia Studies, 66(7), pp. 1031-1061.

Nettler, G. (1957). A Measure of Alienation. American Sociological Review, 22(6), pp. 670-677.

Onyx, J., \& Bullen, P. (2001). The Different Faces of Social Capital in NSW Australia. Social Capital and Participation in Everyday Life, pp.45-58.

Paige, J. (1971). Political Orientation and Riot Participation. American Sociological Review, 36(5), pp. 810-820.
Paldam, M., \& Svendsen, G. T. (2000). An Essay on Social Capital: Looking for the Fire behind the Smoke. European Journal of Political Economy, 16(2), pp. 339-366.

Pokrovski, N. (2008). Universum Odinochestva [Universe of Loneliness]. Moskva: Logos (in Russian).

Putnam, R. (2000). Bowling Alone: Civic Disengagement in America. New York, NY: Simon \& Schuster.

Putnam, R., Leonardi, R., \& Nanetti, R. (1993). Making Democracy Work: Civic Traditions in Modern Italy. Princeton NJ: Princeton University Press.

Roberts, B. R. (1987). A Confirmatory Factor-Analytic Model of Alienation. Social Psychology Quarterly, 5o(4), pp. 346-351.

Schwartz, S.H. (2012). An Overview of the Schwartz Theory of Basic Values. Online Readings in Psychology and Culture, 2(1), p.11.

Schyns, P., \& Nuus, M. (2007). Political Cynicism and Social Cohesion in Europe and the United States. Social Capital and Governance: Old and New Members of the EU in Comparison, pp. 91-103.

Seeman, M. (1959). On the Meaning of Alienation. American Sociological Review, 24(6), pp. 783-791.

Skarżyńska, K. \& Chmielewski, K. (1995). Young People in the World of Politics: Associated with the New System of Alienated from it? Polish Psychologica Bulletin, 26(1), pp. 57-71.

Srole, L. (1956). Anomie, Authoritarianism, and Prejudice. American Journal of Sociology, 62(1), pp. 63-67.

Stolle, D. (2003). The Sources of Social Capital. In M. Hooghe, \& D. Stolle (Eds.), Generating Social Capital: Civil Society and Institutions in Comparative Perspective (pp. 19-42). New York, NY: Palgrave Macmillan.

Supule, I. (2005). Active Civic Participation of Immigrants in Latvia. Country Report Prepared for the European Research Project Politis. Riga: BISs. Retrieved from www.uni-oldenburg.de/politis-europe/country-reports

Teevan Jr., J.J. (1975). On Measuring Anomia: Suggested Modification of the Srole Scale. Pacific Sociological Review, pp. 159-170.

Vingender, I. (2001). Anomija i deviacija v vengerskom obshhestve. [Anomie and the deviation in the Hungarian society]. Sotsiologicheskie Issledovaniya, 3 , s. 84-89 (in Russian).

Woolcock, M., \& Narayan, D. (2000). Social Capital: Implications for Development Theory, Research and Policy. The World Bank Research Observer, 15(2), pp. 225-249.

Zepa, B. (1999). Conditions of Enhancement of Civic Participation. Riga: Baltic Data House. 
4 AR BALSI VIEN ? MEDIJU PATÉRIN̦A,

VẼRTİBORIENTĀCIJU UN VALDİBAS DARBĪBAS VĒRTËJUMA IETEKME UZ LATVIJAS IEDZĪVOTĀJU ATTIEKSMĒM PRET VALSTS DROŠİBU

Andersen, R. (2012). Support for Democracy in Cross-national Perspective: The Detrimental Effect of Economic Inequality. Research in Social Stratification and Mobility, 30(4), pp. 389-402.

Brewer, P. R., Graf, J., \& Willnat, L. (2003). Priming or Framing: Media Influence on Attitudes toward Foreign Countries. Gazette (Leiden, Netherlands), 65(6), pp. 493-508.

Clemons, R. S., Peterson, R. D., \& Palmer, C.L. (2016). Priming Assad: An Experiment of Ethnic Priming and Attitudes Toward Military Action in Syria. Foreign PolicyAnalysis, 12(3), pp. 433-449.

Durkheim, E. (1951). Suicide: A Study in Sociology. J.A. Spaulding, \& G. Simpson (transl.). Glencoe, IL: Free Press. (Original work published 1897).

The Economist (2017). The Economist Intelligence Unit's Democracy Index Retrieved 10.11.2017 from https://infographics.economist.com/2018/ DemocracyIndex/

Flaxman, S., Goel, S., \& Rao, J.M. (2016). Filter Bubbles, Echo Chambers, and Online News Consumption. Public Opinion Quarterly, 80(S1), pp. 298-320.

Freedom House (2017). Freedom in the World. Retrieved 10.11.2017 from https:// freedomhouse.org/report/freedom-world/2017/russia

Gelissen, J. (2007). Explaining Popular Support for Environmental Protection: A Multilevel Analysis of 50 Nations. Environment and Behavior, 39(3), pp. 392-415

Gilley, B. (2006). The Meaning and Measure of State Legitimacy: Results for 72 Countries. European Journal of Political Research, 45(3), pp. 499-525.

Goffman, E. (1974). Frame Analysis: An Essay on the Organization of Experience. Cambridge, MA, Us: Harvard University Press.

Gurr, T.R. (1970). Why Men Rebel. Princeton, NJ: Princeton UP.

Hastie, R., \& Park, B. (1986). The Relationship between Memory and Judgment Depends on whether the Judgment Task is Memory-based or On-line. Psychological Review, 93(3), p. 258.

Henn, M., Oldfield, B., \& Hart, J. (2017). Postmaterialism and Young People's Political Participation in a Time of Austerity. The British Journal of Sociology.

Hudson, V. (2015). ‘Forced to Friendship'? Russian (Mis-) Understandings of Soft Power and the Implications for Audience Attraction in Ukraine. Politics, 35(3-4), pp. 330-346.

Inglehart, R. (1977). The Silent Revolution: Political Change Among Western Publics. Princeton: Princeton University Press.

Inglehart, R. (1990). Culture Shift in Advanced Industrial Society. Princeton University Press.
Inglehart, R. (2003). How Solid is Mass Support for Democracy-and How Can We Measure It? PS: Political Science \& Politics, 36(1), pp. 51-57.

Iyengar, S., \& Kinder, D. R. (2010). News that Matters: Television and American Opinion. University of Chicago Press.

Jacoby, W. G. (1991). Ideological Identification and Issue Attitudes. American Journal of Political Science, pp.178-205.

Kahneman, T. (1979). Prospect Theory: Analysis of Decision under Risk. Econometrician, 47, pp.192-263.

Kaprāns, M. (2014). Vecs vīns vecā ādas maisā: Latvijas ierāmēšana Krievijas medijos. No Kudors, A. Krievijas publiskā diplomātija Latvijā: mediji un nevalstiskais sektors. Rīga: LU Akadēmiskais apgāds, 57.-75.lpp.

Knutsen, O. (2012). 11 Party choice. Society and Democracy in Europe, p. 244

Kudors, A. (2014). Krievijas publiskā diplomātija Latvijā: mediji un nevalstiskais sektors. Rỉga: LU Akadēmiskais apgāds, 221.lpp.

Lazarsfeld, P.F., Berelson, B., \& Gaudet, H. (1944). The People's Choice. New York, NY: Columbia University Press.

Levi, M., Sacks, A., \& Tyler, T. (2009). Conceptualizing Legitimacy, Measuring Legitimating Beliefs. American Behavioral Scientist, 53(3), pp. 354-375

Lipset, S. M. (1959). Political Man:The Social Bases of Politics. Garden City, NY: Anchor Books.

McCombs, M.E., \& Shaw, D. L. (1972). The Agenda-setting Function of Mass Media. Public Opinion Quarterly, 36(2), pp. 176-187.

Muižnieks, N., \& Zelče, V. (2011). Karojošă piemiña: 16. marts un 9. maijs. Rïga: LU SZF SPPI.

Nielsen, K., \& Paabo, H. (2015). How Russian Soft Power Fails in Estonia:

Or, Why the Russophone Minorities Remain Quiescent. Journal on Baltic Security, 1(2), pp.125-157.

Pariser, E. (2011). The Filter Bubble: What the Internet is Hiding from you. Penguin UK. Pharr, S.J., \& Putnam, R. D. (Eds.) (2000). Disaffected Democracies: What's Troubling the Trilateral Countries? Princeton University Press.

Piurko, Y., Schwartz, S.H., \& Davidov, E. (2011). Basic Personal Values and the Meaning of Left-right Political Orientations in 20 Countries. Political Psychology, 32(4), pp. 537-561.

Rathbun, B. C., Kertzer, J.D., Reifler, J., Goren, P., \& Scotto, T.J. (2016). Taking Foreign Policy Personally: Personal Values and Foreign Policy Attitudes. International Studies Quarterly, 6o(1), pp.124-137.

Rico, G., \& Anduiza, E. (2016). Economic Correlates of Populist Attitudes: anxAnalysis of Nine European Countries in the Aftermath of the Great Recession. Acta Politica, pp. 1-27.

Rohrschneider, R. (1993). Environmental Belief Systems in Western Europe: A Hierarchical Model of Constraint. Comparative Political Studies, 26(1), pp. 3-29. 
Rosefielde, S., \& Hlouskova, R. (2007). Why Russia is not a Democracy. Comparative Strategy, 26(3), pp. 215-229.

Schwartz, S.H. (2012). An Overview of the Schwartz Theory of Basic Values. Online readings in Psychology and Culture, 2(1), p.11.

Schwartz, S. H., Caprara, G.V., Vecchione, M., Bain, P., Bianchi, G., Caprara, M. G., ... \& Mamali, C. (2014). Basic Personal Values Underlie and Give Coherence to Political Values: A Cross National Study in 15 Countries. Political Behavior, 36(4), pp. 899-930.

Sergunin, A., \& Karabeshkin, L. (2015). Understanding Russia's Soft Power Strategy. Politics, 35(3-4), pp. 347-363.

Simons, G. (2015). Taking the New Public Diplomacy Online: Russia and China. Place Branding and Public Diplomacy, 11(2), pp. 111-124.

Skillen, D. (2016). Freedom of Speech in Russia: Politics and Media from Gorbachev to Putin. Vol. 108. Taylor \& Francis.

Tversky, A., \& Kahneman, D. (1981). The Framing of Decisions and the Psychology of Choice. Science, 211(4481), pp. 453-458.

Uhlaner, L., \& Thurik, R. (2007). Postmaterialism Influencing Total Entrepreneuria Activity across Nations. Journal of Evolutionary Economics, 17(2), p. 161-185.

Vecchione, M., Schwartz, S. H., Caprara, G.V., Schoen, H., Cieciuch, J., Silvester, J., ... \& Mamali, C. (2015). Personal Values and Political Activism: A Cross-national Study. British Journal of Psychology, 106(1), pp. 84-106.

Warren, M.E. (Ed.) (1999). Democracy and Trust. Cambridge University Press.

Weber, M. (1905). Die protestantische Ethik und der Geist des Kapitalismus. Archiv für Sozialwissenschaften und Sozialpolitik, Bd. XX und XXI, 99, S. 8080.

Willnat, L., Graf, J., \& Brewer, P. R. (2000). Priming International Affairs: How the Media Influence Attitudes toward Foreign Countries. Gazette, 65(6), pp. 493-508.
5 ANOMIJA DEMOGRĀFIJAS KONTEKSTĀ.

ANOMIJAS UN SOCIĀLO FAKTORU

IETEKME UZ REPRODUKTİVAJIEM

NODOMIEM UN TO REALIZĀCIJU

ACS. Retrieved from https://www.census.gov/newsroom/releases/archives/ american_community_survey_acs/cb11-tps4o.html

Ajzen, I. (1991). The Theory of Planned Behavior. Organizational Behavior and Human Decision Processes, 5o(2), pp.179-211.

«Anomie». Merriam-Webster, 2017. Retrieved 18.07.2017 from https://www.merriamwebster.com/dictionary/anomie

Astone, N. M., Nathanson, C.A., Schoen, R., \& Kim, Y.J. (1999). Family Demography, Social Theory, and Investment in Social Capital. Population and Development Review, 25(1), pp.1-31.

Bühler, C., \& Philipov, D. (2005). Social Capital Related to Fertility: Theoretical Foundations and Empirical Evidence from Bulgaria. Vienna Yearbook of Population Research, pp. 53-81.

Durkheim, E. (2014). The Division of Labor in Society. New York: Simon and Schuster. Genov, N. (1998). Transformation and Anomie: Problems of Quality of Life in Bulgaria. Social Indicators Research, 43(1), pp. 197-209.

IZM (2001). IZM pārskats par Latvijas augstskolu darbïbu 2001. gadà.

Kapitány, B., \& Spéder, Z. (2012). Realization, Postponement or Abandonment of Childbearing Intentions in Four European Countries. Population, 67(4), pp. 599-629.

Kotowska, I., \& Jóźwiak, J. (Eds.) (2003). Population of Central and Eastern Europe: Challenges and Opportunities. European Population Conference, Warsaw, 26-30 August 2003.

Legge, S., Davidov, E., \& Schmidt, P. (2008). Social Structural Effects on the Leve and Development of the Individual Experience of Anomie in the German Population. InternationalJournal of Conflict and Violence (IJCV), 2(2), pp. 248-267.

Lesthaeghe, R., \& Surkyn, J.R. (2002). New Forms of Household Formation in Central and Eastern Europe. Are they Related to Newly Emerging Value Orientations, 1.

Levina, J., Mārtinsone, K., \& Klince, K. (2016). Relation between anomia and values of the inhabitants of the Baltic states. Society. Integration. Education. Proceedings of the International Scientific Conference. Vol.1, May 27-28, pp. 431-446.

Magun, V.S. (2010). Bazovye tsennosti rossijan v evropejskom kontekste [Basic Values of Russians in the European Context] (stat'ja pervaja). Obshhestvennye nauki $i$ sovremennost, 3 (in Russian).

Matsumoto, D. (2009). The Cambridge Dictionary of Psychology. Cambridge University Press. 
OECD Family Database. Retrieved from http://www.oecd.org/els/family/ database.htm

Perelli-Harris, B. (2005). The Path to Lowest-low Fertility in Ukraine. Population Studies, 59(1), pp. 55-70.

Perelli-Harris, B. (2006). The Influence of Informal Work and Subjective WellBeing on Childbearing in Post-Soviet Russia. Population and Development Review, 32(4), pp. 729-753.

Philipov, D. (2003). Fertility in Times of Discontinuous Societal Change. Population of Central and Eastern Europe: Challenges and Opportunities. Warsaw, Statistical Publishing Establishment, pp. 665-690.

Philipov, D., \& Shkolnikov, V. (2001, March). Fertility Intentions and Coping Strategies: Results from the Russian Longitudinal Monitoring Survey. In Annual Meeting of the Population Association of America. Washington DC.

Philipov, D., Spéder, Z., \& Billari, F.C. (2006). Soon, Later, or Ever? The Impact of Anomie and Social Capital on Fertility Intentions in Bulgaria (2002) and Hungary (2001). Population Studies, 60(3), pp. 289-308.

Quesnel-Vallée, A., \& Morgan, S.P. (2003). Missing the Target? Correspondence of Fertility Intentions and Behavior in the US. Population Research and Policy Review, 22(5), pp.497-525.

Schoen, R., Kim, Y.J., Nathanson, C. A., Fields, J., \& Astone, N. M. (1997). Why do Americans Want Children? Population and Development Review, pp. 333-358.

Spéder, Z., \& Kapitány, B. (2012). Realising Birth Intentions in European Comparison-Understanding the Post-communist Fertility Transition. Working Papers on Population, Family and Welfare, 15.

Srole, L. (1956). Social Integration and Certain Corollaries: An Exploratory Study. American Sociological Review, 21(6), pp. 709-716.

Surkyn, J., \& Lesthaeghe, R. (2004). Value Orientations and the Second Demographic Transition (SDT) in Northern, Western and Southern Europe: An Update. Demographic Research, 3, pp. 45-86.

Teymoori, A., Jetten, J., Bastian, B., Ariyanto, A., Autin, F., Ayub, N., ... \& Cui, L. (2016). Revisiting the Measurement of Anomie. PloS one, 11(7), e0158370.

Walter, E. (Ed.) (2008). A State of no Moral or Social Principles in a Person or in Society. Ernst Klett Sprachen. Retrieved from https://dictionary.cambridge. org/dictionary/english/anomie\#translations

\section{ANOMIJA LATVIJAS SVĒTKU UN PIEMINAS} DIENU KALENDĀRĀ UN PRAKS $\bar{E}$

Antonevičs, M. (2018, 23.febr.). Asinainā «vïriešu diena». la.lv. Izgūts no http:// www.la.lv/asinaina-viriesu-diena/

Aron, L. (2012). Roads to the Temple. Truth, Memory, Ideas, and Ideals in the Making of Russian Revolution, 1987-1991. New Haven, London: Yale University Press.

Asare, I. (2017, 13.jūl.). İstenots kultūras projekts Cēsu kauju dienu atcerei. Vidzeme. Vidzemes plānošanas reǵiona mājaslapa. Izgūts no http://www. vidzeme.lv/lv/kulturas jaunumi/41/131102/

Augsstākā Padome (1990). Par svētku un atceres dienām. Pieṇemts 03.10.199o. [ar vairākkārtīgiem grozijumiem]. Izgūts no https://likumi.lv/doc.php?id=72608 Árlietu minstrija (2015, 28.janv.). Latvijas starptautiskās atzišanas de iure 90 gad 26. janvārī. Izơūts no http://www.mfa.gov.lv/ministrija/arlietu-dienestavesture/latvijas-starptautiska-atzisana-de-iure-1921-gada-26-janvari/latvijasstarptautiskas-atzisanas-de-iure-90-gadi-26-janvari

Ārlietu ministrija (2017, 26.janv.). Ārlietu ministrijā atzīmē Latvijas Republikas starptautiskās de iure atzišanas 96. gadadienu. Jurista Vārds. Izgūts no http://www.juristavards.lv/zinas/270036-rlietu-ministrija-atzime-latvijasrepublikas-starptautiskas-de-iure-atzisanas-96-gadadienu/

Ārlietu ministrija (2018a, 26. janv.). Latvijas starptautiskās de iure atzišanas dienā pieminam bijušos diplomātus un Ārlietu ministrijas darbiniekus. Izgūts no http://www.mfa.gov.lv/aktualitates/zinas/58967-latvijas-starptautiskas-deiure-atzisanas-diena-pieminam-bijusos-diplomatus-un-arlietu-ministrijasdarbiniekus

Árlietu ministrija (2018b, 26.janv.). Ārlietu ministrijā atzīmē Latvijas Republikas starptautiskās de iure atzišanas 97.gadadienu. Izgūts no http://www.mfa.gov. lv/aktualitates/zinas/58984-arlietu-ministrija-atzime-latvijas-republikasstarptautiskas-de-iure-atzisanas-97-gadadienu

Biedrība VITA (2017, 31. maijs). Aptauja: tikai 1\% Latvijas aptaujāto iedzīvotāju ir pārliecināti, ka viniem nekad nebūs «vēzis». Izgūts no http://biedribavita. lv/aptauja-tikai-1-latvijas-aptaujato-iedzivotaju-ir-parliecinati-ka-viniemnekad-nebus-vezis/

Blūzma, V. (2008). Atmodas laiks un nevardarbīgā pretošanās (1986.g. - 1990.g. 4. maijs). No V.Blūzma, T.Jundzis, J. Riekstiņ̌̌, H. Strods, Dž. Šārps. Nevardarbīgāa pretošanās: Latvijas neatkarības atğūšanas cel̆š. 1945-1991. Rỉga: Latvijas Zinātnu akadēmija, 225.-376.lpp.

BNS $(2012,3$. maijs). Prezidents aicina veterānus kara upurus pieminēt 8. maijā. tvnet.lv. Izgūts no http://www.tvnet.lv/zinas/latvija/420339prezidents_aicina_veteranus_kara_upurus_pieminet_8maija

Brēde, A. (sast.) (1979). Svētku varavīksne. Palīgss tradīciju kopēiiem. Rīga: Liesma. 
Bula, D. (2008). Astotā marta atgriešanās: sievietỉbas svinēěana postsociālismā. Letonica, 18, 27.-51.lpp.

Bula, D. (2017, 14. marts). Nesajaukt sievietes, kuras gaida apsveikumus, ar tām, kuras negaida. Delfi.lv. Izgūts no http://www.delfi.lv/news/comment/

comment/dace-bula-nesajaukt-sievietes-kuras-gaida-apsveikumus-ar-tamkuras-negaida. $d$ ? id $=48620147$

Cēsu novada pašvaldība (2017, 7.jūn.). Cēsu kaujām 98; cēsnieki aicināti nest ziedus, apmeklēt kauju rekonstrukciju. Izgūts no http://www.cesis.lv/lv/sakums/ aktualitates/pasakumi/cesu-kaujam-98--cesnieki-aicinati-nest-ziedus-

Chaterjee, C. (2002). Celebrating Women: Gender, Festival Culture, and Bolshevik Ideology, 1910-1939. Pittsburgh: University of Pittsburgh Press.

Chaterjee, C. (2013). From Public, to Private, to Public again: International Women Day in post-Soviet Russia. In J. Buckler, \& E.D.Johnson (Eds.), Rites of Place. Public Commemoration in Russia and Eastern Europe. Evanston: Northwestern University Press. pp.183-200.

Cheskin, A. (2012). Exploring Russian-Speaking Identity from Below: The Case of Latvia. Journal of Baltic Studies, 44(3), pp. 287-312.

Delfi (2014, 14. marts). Cilinskis zaudē ministra krēslu. Izgūts no http://www.delfi.lv/ news/national/politics/cilinskis-zaude-ministra-kreslu.d?id=44302719

Delfi (2017a, 25. marts). Latvijā pieminēs 25. marta deportāciju upurus. Izgūts no http://www.delfi.lv/news/national/politics/latvija-piemines-25martadeportaciju-upurus.d?id=44329599

Delfi (2017b, 14.jūn.). Koncerti, atceres briži un goda sardze: Latvijā piemin 14.jūnija deportācijas. Izgūts no http://www.delfi.lv/news/national/ politics/koncerti-atceres-brizi-un-goda-sardze-latvija-piemin-14-junijadeportacijas.d?id $=48950427$

Delfi (2017c, 21. nov.). Aicina ziedot Valtera Frīdenberga cinnai ar vēzi. Izgūts no http://www.delfi.lv/izklaide/slavenibas/muziki/aicina-ziedot-valterafridenberga-cinai-ar-vezi.d?id=49469505

Drošības policija (2016). Publiskais pārskats par Drošǐbas policijas darbību 2015. gadā. Rīga: Drošibas policija. Izgūts no http://dp.gov.lv/lv/noderigi/ gada-parskati/

Drošǐbas policija (2017). Publiskais pārskats par Drošǐbas policijas darbību 2016. gadā. Rigga: Drošibas policija. Izgūts no http://dp.gov.lv/lv/noderigi/ gada-parskati/

Durkheim, É. (1979). Suicide. A Study in Sociology. New York: The Free Press Durkheim, É. (2001). The Elementary Forms of Religous Life. Oxford: Oxford University Press.

ES māja (2017, 2.maijs). Ko redzēt, dzirdēt un kur piedalities, sagaidot Eiropas dienu 9. maijā. Eiropas Komisijas pārstāvniecība Latvijā. Izgūts no http:// esmaja.lv/eiropas-diena/ko-redzet-dzirdet-un-kur-piedalities-sagaidoteiropas-dienu-9-maija
Etzioni, A. (2001). The Monochrome Society. Princeton, Oxford: Princeton University Press.

Gabre, A. (2018). NRA analizē, kuri simtgades svinību tērinini izskatās pēc bezjēdzīgas izšķērdības. Izgūts no http://nra.lv/latvija/234021nra-analize-kuri-simtgades-svinibu-terini-izskatas-pec-bezjedzigasizskerdibas.htm

Gailāne, G., Kuzṇecova M., \& Sildniks, J. (2017, 16. marts). Leğionāru piemiṇas dienas gājiens beidzies bez starpgadijumiem. Teksta tiešraides arhivss. Delfi.lv. Izgūts no http://www.delfi.lv/news/national/politics/legionarupieminas-dienas-gajiens-beidzies-bez-starpgadijumiem-teksta-tiesraidesarhivs.d?id $=48628085$

Gailišs, V., Gefters, D., Kovaḷenko, J., \& Semjonovs, V. (1988, 22. jūl.). Padomju Latvija 21. jūlijā: atbalsts partijas kursam, pārbūvei un demokratizācijai. Cinna, 1.lpp.

Gefters, D., Grišina, G., Manko, P., Petkeviča, B., Semjonovs, V., Teroganesovs, V., \& Zariňš, E. (1989, 8. nov.). Rīgā, Komjaunatnes krastmalā. Karaspēka parāde un darbalauažu demonstrācija. Cīna, 1.-2.lpp.

Gefters, D., Koval̦enko, J., Kučina, G., Sebjakins, B., \& Švarca, L. (1988, 8. nov.). Rīgā, Komjaunatnes krastmalā. Karaspēka parāde un darbaḷaužu demonstrācija. Ciña, 1.-3.lpp.

Gertners, E. (2010, 10. maijs). Godina savu vēsturisko pārliecību. Neatkarīgāa Rìta Avize Latvijai, 5.lpp.

Gill, G. (2011). Symbols and Legitimacy in Soviet Politics. Cambridge: Cambridge University Press.

Greenfeld, L. (2006). Nationalism and the Mind:Essays on Modern Culture. Oxford: Oneworld Publications.

Grimes, R.L. (2011). Ritual, media, and conflict: An introduction. In R.L. Grimes, U. Hüsken, U. Simon, E. Venbrux (Eds.), Ritual, Media, and Conflict. Oxford: Oxford University Press, pp. 3-61.

Hobsbawm, E. (1983). Introduction: Inventing traditions. In E. Hobsbauwm, T. Ranger (Eds.), The Invention of Tradition. Cambridge: Cambridge University Press, pp.1-14.

Jasinska, M. (2017, 12.jūl.). Renārs Sproğis: Cēsu kaujām jāatdod pienācigā cieṇa. Neatkarīgā Rìta Avīze. Izgūts no http://nra.lv/latvija/215485-renars-sprogiscesu-kaujam-jaatdod-pienaciga-ciena.htm

Jemerga, S., Salu, M., Černiauskas, Š., \& Pancerovas, D. (2015, 27. aug.). Krievijas nauda Baltijā. Miljoni no Kremḷa. Re: Baltica. Izgūts no https://rebaltica. lv/2015/o8/miljoni-no-kremla/

Jēkabpils Galas nams (2016, 23.febr.). Svētku tortes Vīriešu dienā. Izgūts no http:// www.jekabpilsgalasnams.lv/raksti/jaunumi/svetku-tortes-viriesu-diena/

Kantar TNS (2005a, 11. nov.). Latvijas iedzivotāji maz zina par Lāčplēša dienas nozimi. Izgūts no http://www.tns.lv/?lang=lv\&fullarticle=true\&category= showuid\&id $=2290$ 
Kantar TNS (2005b, 16. nov.). Lielai dalai Latvijas iedzivotāju 18. novembris ir parasta brīvdiena. Izgūts no http://www.tns.lv/?lang=lv\&fullarticle=true\&category= showuid\&id $=2292$

Kantar TNS (2006a, 10. nov.). Lielākā dala Latvijas iedzivotāju nezin, kāpēc tiek svinēta Lāčplēša diena. Izgūts no http://www.tns.lv/?lang=lv\&fullarticle=true \&category=showuid\&id $=2501$

Kantar TNS (2006b, 16. nov.). Lielākā daḷa Latvijas iedzīvotāju zina 18. novembra svētku nozīmi. Izgūts no http://www.tns.lv/?lang=lv\&fullarticle=true\&catego ry=showuid\&id $=2506$

Kantar TNS (2006c, 8. marts). Vairākums Latvijas iedzivotāju svin 8. martu. Izgūts no http://www.tns.lv/?lang=lv\&fullarticle=true\&category=showui $\mathrm{d} \& \mathrm{id}=2346$

Kantar TNS (2006d, 21.jūn.). Latviešiem raksturīgi Jānuus un Lïgo pavadīt kopā ar draugiem. Izgūts no http://www.tns.lv/?lang=lv\&fullarticle=true\&category= showuid\&id $=2423$

Kantar TNS (2006e, 22. dec.). Latvijas iedzivotāii Ziemassvētkos kā dāvanu vēlētos san̨emt mobilo telefonu. Izgūts no http://www.tns.lv/?lang=lv\&fullarticle=tr ue\&category $=$ showuid\&id $=2534$

Kantar TNS (2008, 14. nov.). Lielākā daḷa Latvijas iedzīvotāju zina 18. novembra svētku nozìmi. Izgūts no http://www.tns.lv/?lang=lv\&fullarticle=true\&catego $\mathrm{ry}=$ showuid\&id $=2864$

Kantar TNS (2017a, 12.jūn.). 46\% Latvijas iedzìvotāju plāno apmeklēt kādas pilsētas svētkus. Izgūts no http://www.tns.lv/?lang=lv\&fullarticle=true\&category=sh owuid\&id $=5148$

Kantar TNS (2017b, 19. maijs). 35\% Latvijas iedzīvotāju šogad plāno apmeklēt kādu no Muzeju nakts pasākumiem. Izgūts no http://www.tns.lv/?lang=lv\&fullarti cle=true\&category $=$ showuid\&id $=5142$

Kantar TNS (2017c, 12. maijs). 63\% Latvijas iedzīvotāju plāno atzīmēt Mātes dienu. Izgūts no http://www.tns.lv/?lang=lv\&fullarticle=true\&category=showuid\&i $\mathrm{d}=5137$

Kantar TNS (2017d, 8. sept.). Vairāk nekā ceturtā dala iedzivotāju plāno atzīmēt Tēva dienu. Izgūts no http://www.tns.lv/?lang=lv\&fullarticle=true\&category=sho wuid\&id $=5184$

Kantar TNS (2017e, 19. jūn.). Lỉgo svētku laikā vairākums iedzīvotāju cep šašliku vai kurina ugunskuru. Izgūts no http://www.tns.lv/?lang=lv\&fullarticle=true\&ca tegory=showuid\&id $=5151$

Kantar TNS (2017f, 9. nov.). Puse Latvijas iedzivotāju svinēs Lāčplēša dienu. Izgūts no http://www.tns.lv/?lang=lv\&fullarticle=true\&category=showuid\& $\mathrm{id}=5204$

Kantar TNS (2017g, 17. nov.). 18. novembra pasākumus apmeklē pusmiljons iedzivotāju. Izgūts no http://www.tns.lv/?lang=lv\&fullarticle=true\&category $=$ showuid\&id $=5207$
Kantar TNS (2018, 17.janv.). Iedzivotāji gatavojas apmeklēt Latvijas simtgades pasākumus. Izgūts no http://www.tns.lv/?lang=lv\&fullarticle=true\&category $=$ showuid\&id $=5231$

Karlsone, L. (2017, 5.janv.). Latvijas valsts simtgadi svinēs piecus gadus - tas izmaksās gandrīz 60 miljonus eiro. lsm.lv. Izgūts no http://www.lsm.lv/ raksts/kultura/kulturtelpa/latvijas-valsts-simtgadi-svines-piecus-gadus-tas-izmaksas-gandriz-6o-miljonus-eiro.a217793/

Kertzer, D. I. (1988). Ritual, Politics, and Power. New Haven, London: Yale University Press.

Krauze, M. (2017, 4. maijs). Ozolu stādišana, koncerti un balti klāts galds - 4. maija pasākumu kalendārs. Delfi.lv. Izḡūts no http://www.delfi.lv/news/national/ politics/ozolu-stadisana-koncerti-un-balti-klats-galds-4-maija-pasakumukalendars.d?id $=48789791$

LABA (2017, 9. maijs). Darbalaudīs spēks. Arodbiedrība LABA. Izgūts no http://www. arodbiedriba.lv/new $/ 435$

Lane, Ch. (1981). The Rites of Rulers. Ritual in Industrial Society - the Soviet Case. Cambridge: Cambridge University Press.

Langa, L. (2017, 5.janv.). Miljonu tērēšana simtgadei ir noziegums pret nabagiem. Latvijas Avize. Izgūts no http://www.la.lv/vai-sadu-valsti-velamies/

Ločmele, K., Procevska, O., \& Zelče, V. (2011). Uzvaras svētki padomju Latvijā. No N. Muižnieks, V.Zelče (red.), Karojošă piemina. 16. marts un 9. maijs. Rīga: Zinātne, 236.-274.lpp.

Lūsina, I. (2016, 24. dec.). Intervija ar komponistu Jāni Lūsēnu. Stop signāls. Kultūras Diena. Izgūts no https://www.diena.lv/raksts/kd/intervijas/intervija-arkomponistu-jani-lusenu.-stop-signals-14162546

$l v 100 . l v$. Latvijas valsts simtgades digitāāā platforma.

manabalss.lv (2017, 29. nov.). Simtgades svinïbu naudas novirzišana vēža ârstēšanai! Izgūts no https://manabalss.lv/simtgades-svinibu-naudas-novirzisana-vezaarstesanai/show

MIX TV (2015, 9 may). 9 maya 2015 goda $v$ Rige. Prazdnichnaya rech'mera goroda Nila Ushakova. Retrieved from https://www.youtube.com/ watch?v=zRyeZPENQeA

Nacionālā identitāte (2010). Latvijas iedzìvotāju aptauja. Veikta pēc Latvijas Universitātes Sociālo zinātṇu fakultātes Sociālo un politisko pētijuma institūta pasūtijuma valsts pētijuma programmas «Nacionālā identitāte» ietvaros.

Nacionālā identitāte (2014). Latvijas iedzìvotāju aptauja. Veikta pēc Latvijas Universitātes Sociālo zinātnu fakultātes Sociālo un politisko pētijuma institūta pasūtijuma valsts pētijuma programmas «Nacionālā identitāte» ietvaros.

NRA (2016, 23.febr.). Kas Latvijā svin 23. februāri kā vīriešu dienu? Izgūts no http:// nra.lv/latvija/164313-kas-latvija-svin-23-februari-ka-viriesu-dienu.htm 
Orlov, E. (2010, 10 may). Pobeditelyam slava! Chas, S. 1-2.

Puzo, K. (2011). Sieviešu dienas reprezentācija laikraksta «Cīna» publikācijās (1965-1991) (mağistra darbs). Rīga: LU SZF Komunikācijas studiju nodala.

Rolf, M. (2013). Soviet Mass Festivals, 1917-1991. Pittsburgh: University of Pittsburgh Press.

Rothenbuhler, E. W. (1998). Ritual Communication. From Everyday Conversation to Mediated Ceremony. Thousand Oaks: Sage Publications.

Rozenšteine, A., Saulītis, A., Siliṇa, G., \& Zelče, V. (2011). 16. marts - piemiṇas un konfrontācijas diena. No N. Muižnieks, V.Zelče (red.), Karojošă piemina. 16. marts un 9. maijs. Rīga: Zinātne, 145.-170.lpp.

Sargs.lv (2017, 10. aug.). Aizsardzības ministrija rosina 10. jūliju oficiāli noteikt par Latvijas karaviru dienu. Izgūts no http://www.sargs.lv/Zinas/ Latvija/2017/08/10-01.aspx\#lastcomment

Sherlock, T. (2007). Historical Narratives in the Soviet Union and the Post-Soviet Russia. Destroying the Settled past, Creating an Uncertain Future. New York: Palgrave Macmillan.

Skangale, L. (2008). Latvijas valsts svêtku, atceres un atzīmējāmāàs dienas. 3.izd. Riga: Zvaigzne ABC.

Skaties.lv (2018, 23. febr.). Samanta Tīna sveic visus Latviešus puišus Viriešu dienā. Izgūts no https://skaties.lv/izklaide/slavenibas/muziki/samanta-tina-sveicvisus-latvijas-puisus-viriesu-diena/

Smith, K. E. (1996). Remembering Stalin's Victims. Popular Memory and the Enf of the USSR. Ithaca, London: Cornell University Press.

SUSTINNo (2015). Latvijas iedzìvotāju aptauja. Veikta pēc Latvijas Universitātes Sociālo zinātṇu fakultātes Sociālo un politisko pētijuma institūta pasūtijuma valsts pētijuma programmas «Inovācija un ilgtspējiga attistiba: Latvijas pēckrīzes procesi globālā kontekstā (SUSTINNO)» ietvaros.

SUSTINNO (2016). Latvijas iedzīvotāju aptauja. Veikta pēc Latvijas Universitātes Sociālo zinātṇu fakultātes Sociālo un politisko pētijuma institūta pasūtỉjuma valsts pētijuma programmas «Inovācija un ilgtspējīga attīstība: Latvijas pēckrīzes procesi globālā kontekstā (SUSTINNO)» ietvaros.

Tvnet (2018, 28.janv.). Teju ceturtdaḷmiljonu izmaksājušie «Goda vārti» tiks nojaukti pēc diviem gadiem. Izgūts no http://www.tvnet.lv/zinas/ latvija/77086o-teju_ceturtdalmiljonu_izmaksajusie_goda_varti_tiks_ nojaukti_pec_diviem_gadiem

Ušakovs, N. (2016, 9. maijs). Rīgas mēra Nila Ušakova uzruna Uzvaras dienā. 9may. $l v$. Izgūts no http://9may.lv/lv/zinas/news/rigas-mera-nila-usakova-uzrunauzvaras-diena/

Ušakovs, N. (2017, 10. maijs). Nila Ušakova uzruna 9. maijā. YouTube. Izgūts no https://www.youtube.com/watch?v=y63UNhoRV98

Vārpa, I. (2012). Atmodas eiforija un atmošanās pağiras. 1. sēj. Rīga: Zvaigzne ABC.
Vose, L. (2009). Latvijas valsts 90. gadadienas svētku rituāla naratìvs latviešu lielākajos nacionālās preses izdevumos «Diena», «Latvijas Avīze», «Neatkarìgā Rìta Avīze Latvijai» (maĝ́istra darbs). Rīga: LU SZF Komunikācijas studiju nodala.

Yarskaya-Smirnova, E., \& Karpova, G. (2003). Simbolicheskii repertuar gosudarsvenoi politiki: Mezhdunarodnyi zhenskii den'v rossiiskoi presse, 1920-2001 gg. V kn. N.Pushkareva (red.), Sotsial'naya istoriya: Ezhegodnik, 2003. Zhenskaya i genderaya istoriya. Moskva: ROSSPEN, s. 488-509.

Zelče, V. (2011). Latviešu leğiona atmiṇa un piemiṇas dienas Latvijā sākotne. No N. Muižnieks, V.Zelče (red.), Karojošā piemiṇa. 16. marts un 9. maijs. Rïga: Zinātne, 123.-144.lpp.

Zelče, V. (2011). Uzvaras svētki padomju Latvijā. No N. Muižnieks, V.Zelče (red.) Karojošā piemiṇa. 16. marts un 9. maijs. Rīga: Zinātne, 196.-237.lpp.

Zelče, V. (2018). The Transformation of 'Holiday' in Post-Soviet Space: Celebrating Soviet Victory Day in Latvia. Europe-Asia Studies. 70(3), 388-420.

Zile, Ḷ. (1998). Sabiedrïbas atraisišsanās no Helsinki-86 līdz Tautas frontei. 1986.gads-1988. gada oktobris. No V.Blūzma, O.Celle, T.Jundzis, D.A. Lēbers, E. Levits, L. Zile. Latvijas valsts atjaunošana. 1986.-1993. Rīga: LU žurnāla «Latvijas Vēsture» fonds, 87.-148.lpp.

Žukova, K. (2018a, 15. marts). Saeima izbrāḳ̂e 'nacionālu'u' ierosinājumu 16. martu noteikt par atzimējamu dienu. delfi.lv. Izgūts no http://www.delfi.lv/news/ national/politics/saeima-izbrake-nacionalu-ierosinajumu-16-martu-noteiktpar-atzimejamu-dienu.d?id $=49841239$

Žukova, K. (2018b, 15. marts). Deputāti vērtēs ieceri Lāčplēša dienu - 11. novembrinoteikt par brivdienu. delfi.lv. Izgūts no http://www.delfi.lv/news/national/ politics/deputati-vertes-ieceri-lacplesa-dienu-11-novembri-noteikt-parbrivdienu.d?id $=49841367$

Žukova, K. (2018c, 20. marts). Latvijā būs trīs jaunas atzimējamas dienas, lemj valdïba. delfi.lv. Izgūts no http://www.delfi.lv/news/national/politics/latvijabus-tris-jaunas-atzimejamas-dienas-lemj-valdiba.d?id=49858797 


\section{AUTOR I}

\section{JĀNIS IKSTENS, DR. SC. POL.}

Latvijas Universitātes Sociālo zinātṇu fakultātes Politikas zinātnes nodalasas profesors, Sociālo un politisko pētijumu institūta vadošais pētnieks. Pētnieciskās intereses: vēlēšanu analīze, politiskās partijas, politisko partiju finansējums.

\section{INTA MIERIN̦A, PH.D.}

Latvijas Universitātes Diasporas un migrācijas pētijumu centra direktore, Latvijas Universitātes Sociālo zinātṇu fakultātes

Socioloğijas nodaḷas asociētā profesore. Pētnieciskās intereses:

migrācija, nacionālisms un galēji labējās attieksmes, nevienlīdzība, uzticība un pilsoniskā iesaiste.

\section{AGITA MISĀNE, DR. PHIL.}

Latvijas Universitātes Sociālo un politisko pētỉjumu institūta pētniece, sociolog̣ijas nodąlas docente. Zinātniskās intereses, publikācijas un pedagoğiskais darbs saistìts ar reliǵiju un ideju vēsturi Latvijā, reliğijas socioloğiju un teorētisko socioloğiju.

\section{VISVALDIS VALTENBERGS, DR. SC. POL.}

Vadošais pētnieks Latvijas Universitātes Sociālo zinātṇu fakultātes Sociālo un politisko pētījumu institūtā. Pētnieciskās intereses: interneta politiskā komunikācija, sabiedrības vērtības globālajā kontekstā, vietējā un reğionālā attīstība.

\section{ZANE VĀRPIN̦A, DR. DEMO.}

Rỉgas Ekonomikas augstskolas docente, Latvijas Universitātes Sociālo zinātnu fakultātes Sociālo un politisko pētijumu institūta pētniece. Pētnieciskās intereses: demogrāfija, augstākā izglìīiba.

\section{VITA ZELČE, DR. HIST.}

Latvijas Universitātes Sociālo zinātṇu fakultātes Komunikācijas studiju nodaḷas profesore, Sociālo un politisko pētījumu institūta vadošā pētniece. Pētnieciskās intereses: sociālā atmiṇa un vēstures politika, komunikācijas vēsture, mediji.

\section{AIJA ZOBENA, DR. SC. SOC.}

Latvijas Universitātes Sociālo zinātnu fakultātes Socioloğijas nodalas profesore, Sociālo un politisko pētījumu institūta direktore un vadošā pētniece. Pētnieciskās intereses: lauku un reǵ̛ionālā attīstība. 


\section{Lost in freedom: anomy in contemporary Latvia}

The collective monograph Lost in freedom: anomy in contemporary Latvia (scientific editor Aija Zobena) summarizes the main findings of the research project "Value orientations and reproduction of society", carried out within the framework of State Research Program "Innovation and sustainable development: Latvia's post-crisis experience in a global context" (SUSTINNO). This project was implemented at the Advanced Social and Political Research Institute, University of Latvia Faculty of Social Sciences from 2014 to 2018

The aim of this project was to study value orientations and norms of Latvian society in order to understand the influence of media and Soviet regime on their genesis, and to determine the prevalence of anomy in society. It would further allow to analyze the impact of these value orientations on social behavior, including the forms of participation in society (especially among youth), the evolution of family models and reproductive behavior.

In any case, anomy is an exceptional, abnormal condition that occurs when social links of individual and wider community are weakened and thus individual's identification with community values is also weakened. The risk of anomy in transition societies, including Latvia, is always objectively higher than in established societies. Some of the old social institutions have been abolished, and new ones have emerged but have not yet received sufficien authority. Society members have to construct new identities. A part of socia norms no longer function. Classic challenges include the change of citizenship status, adaptation to another state language and economic system, money, property structures, education or pension system reforms. Even many years after regaining independence and, to a certain extent, in connection with the processes of society change, Latvia has a high level of alienation of the population, as well as an extremely pronounced political alienation. Anomie in Latvia consists of several dimensions that are slightly different and yet closely related to academic literature (Marx, Durkheim, etc.): powerlessness, alienation from oneself, lack of norms, cultural alienation and isolation, lack of clear faith, lack of long-term goals and vision, alienation from family and responsibility. Powerlessness and alienation from oneself are the most pronounced dimensions of anomie, followed by lack of norms and faith. It is the lack of norms, clea beliefs and long-term goals and visions that can be regarded as the most problematic aspects of Latvian society. They are particularly characteristic to the poorest segments of the society. Alongside non-Latvians, the poorer people more often experience powerlessness and alienation from themselves. Political and social alienation, although related to anomie, particularly by lack of clear faith, is characterized by different cognitive concepts (hence, political non-participation, social bond weakness and society fragmentation cannot be regarded as a direct sign of anomie). Interestingly, young people feel socially and culturally alienated, while older people are more politically alienated. 
In the first chapter of the monograph "THE THEME AND THEORIES OF ANOMIE IN SOCIAL SCIENCES", AGITA MISĀNE introduces the concept of anomie and its development in social sciences from the end of the nineteenth century to the beginning of the 21st century. Anomie was considered to be a classic sociological topic since its extensive interpretations are found in works by founder of sociology Émile Durkheim (1858-1917), in particular his doctoral thesis "From the division of social work" (De la division du travail social, 1893) and "Suicide" (Le Suicide, 1897). The very concept of anomie and its interpretation that anomie is a situation whose character is sought in relations between individuals and social institutions became one of the most important topics in Durkheim's sociology. Over the past decades, more research has been done on anomie in a territorial context and in particular societies; anomie is being intensively studied in context of specific organizations or social groups, and attempts to synthesize the above-mentioned specific research with a new theoretical proposition that seeks anomie indicators outside the context of individual anomie symptoms.

In the next chapter "ORIENTATION OF GLOBAL VALUES AMONG PEOPLE OF LATVIA", VISVALDIS VALTENBERGS points out that social and psychological dimension of sustainability is an important component for understanding the processes of globalization. In all countries, the groups of society differ in their use of the opportunities offered by globalization process. Some groups would be willing to disassociate from effects of globalization, while others would like to make greater use of the opportunities offered by globalization in labor market, trade, exchange of knowledge and many other areas. The society value background is of great importance for implementation of policies related to the international dimension. The research findings that are based on results of surveys conducted by the International Social Surveys Program (ISSP) and the State Research Program SUSTINNO "Public Value Orientation and Society Regeneration" show that values and attitudes are weak explanatory factors of subjective global orientation (ISSP Research Group, 1998, 2012, 2015; SUSTINNO, 2015). It is the demographic factors, in particular income and education, that have a greater impact on the sense of interest of respondents and their identification with parts of the world beyond national borders. Citizens' values and attitudes play a greater role in explaining people's interest in events in specific regions. The study confirms that respondents with more distinct traditional values show greater interest regarding events in their own region. However, respondents with pronounced universalism values show more interest in events not only in their own city, area, Russia, but also in other regions of the world.

In the third chapter of the monograph "Political Alienation AND ANOMY IN CONTEMPORARY LATVIA", INTA MIERINA focuses on political anomie in Latvian society. A quarter of a century after regaining independence Latvia is still characterized by a high level of corruption and nepotism, while civil society's development is hampered by political cynicism, apathy and distrust in government. Previous studies show simultaneous presence of high social exclusion risks, social fragmentation, lack of social trust and lack of empathy. Some scholars regard this situation as a legacy of the communist regime, while others point to the negative effects of transition process. The author presents a social diagnosis of "postmodern condition" in Latvia, using the classic notions of alienation and anomy. The sociological framework allows us to examine the difficulties of coping with the past in wider context of values and internal norms.

The study of political anomie in the fourth chapter of the monograph "THE VOICE ALONE? IMPACT OF MEDIA CONSUMPTION, VALUE ORIENTATION AND GOVERNMENT WORK VALUATION ON ATTITUDES OF LATVIAN CITIZENS REGARDING STATE SECURITY" is continued by JĀNIS IKSTENS, exploring the extent of resonance of messages that Russia actively communicates in its propaganda against Latvia in Latvian society. What factors contribute (or hinder) the susceptibility to Russian propaganda messages? This analysis also includes independent variables such as individual value orientation, socio-demographic characteristics, and views on government work. Previous studies suggest that each of these groups of independent variables has a certain impact on individuals' political beliefs. The author suggests that media consumption habits act as the main determinant of susceptibility to the encoded attitudes of Russian propaganda.

ZANE VĀRPIN in the fifth chapter of the monograph "IMPACT OF ANOMIE AND SOCIAL FACTORS ON REPRODUCTIVE INTENTIONS AND THEIR REALIZATION" focuses on changes that social and economic development has introduced in reproductive decision making process in Latvia, where the total fertility rate still remains below the conventional population reproduction coefficient (2.1). According to demographic literature, the three most important theoretical explanations of reasons behind the persisting low birth rates in Central and Eastern European countries, including Latvia after regaining of independence, are economic insecurity, Second Demographic Transition, and anomie of society. However, no micro-level empirical evidence has been obtained for all these explanations. For example, the studies have not established a direct relationship between the number of children in family, economic situation, employment or income level. Furthermore, there is insufficient evidence of relationship between changes in the value system and birth rates. Even fewer demographic studies have hitherto focused on the impact of anomie on demographic behavior.

The chapter "ANOMIE in CALENDAR AND PRACTICE OF LATVIAN HOLIDAYS AND MEMORIAL DAYS" concludes the monograph. Here, ViTA ZELČE, using the anomie concept of Émile Durkheim, provides a discussion 
of the calendar of Latvian national holidays, commemoration, celebrations and commemorative practices. It is based on analysis of the results of sociological survey commissioned by the University of Latvia Faculty of Social Sciences and analysis of holidays and memorial days. Looking at four groups of celebrations and memorial days, 1) national and patriotic holidays; 2) commemoration days of communist and Nazi totalitarian regime victims; 3) celebrations as a legacy of the Soviet regime, and 4) tension management festivities, the author concludes that in some areas of the culture of Latvian holidays, commemoration and celebration days, anomy is observed, revealing contradictions between the existing life styles and the identities and values of social groups and individuals.

\begin{tabular}{l|l} 
Acknowledgements & The authors of this monograph would
\end{tabular} like to thank all contributors to the creation of this work. A particular gratitude is extended to Professor Jānis Ikstens, leader of the State Research Program "Innovation and sustainable development: Latvia's post-crisis experience in a global context" (SUSTINNO) and head of the project "Value orientations and reproduction of society" in the period from 2014 to 2017 for creative input to the program, realization and formulation of the idea of this monograph. The authors are obliged to Zane Vārpina for English translation of the texts.

Scientific editor

Dr. sc. soc. Aija Zobena 
AUTHORS

\section{JĀNIS IKSTENS, DR. SC. POL.}

Professor at the Department of Political Science, Senior Researcher at the Advanced Social and Political Research Institute, Faculty of Social Sciences, University of Latvia. Research interests: analysis of elections, political parties, financing of political parties.

\section{INTA MIERIN̦A, PH.D.}

Director of the Centre for Diaspora and Migration Research at the University of Latvia, Associate Professor at the Department of Sociology, Faculty of Social Sciences, University of Latvia. Research interests: migration, nationalism and far-right attitudes, inequality, participation, trust and community involvement.

\section{AGITA MISĀNE, DR. PHIL.}

Docent at the Department of Sociology, Researcher at the Advanced Social and Political Research Institute (ASPRI), Faculty of Social Sciences, University of Latvia. Research interests: religion and history of ideas in Latvia, sociology of religion and theoretical sociology.

\section{VISVALDIS VALTENBERGS, DR. SC. POL.}

Senior Researcher at the Advanced Social and Political Research Institute (ASPRI), Faculty of Social Sciences, University of Latvia. Research interests: internet political communication, society values in global context, local and regional development.

\section{ZANE VĀRPIN̦A, DR. DEMO.}

Assistant Professor at Stockholm School of Economics in Riga, Researcher at the Advanced Social and Political Research Institute (ASPRI), Faculty of Social Sciences, University of Latvia. Research interests: demography, higher education.

VITA ZELČE, DR. HIST.

Professor at the Department of Communication Science, Senior Researcher at the Advanced Political and Social Research Institute, Faculty of Social Sciences, University of Latvia. Research interests: social memory and history policy, history of communication.

\section{AIJA ZOBENA, DR. SC. SOC.}

Professor at the Department of Sociology, Director and Senior Researcher at the Advanced Social and Political Research Institute (ASPRI), Faculty of Social Sciences, University of Latvia. Research interests: rural and regional development. 
Grāmatas dizainu un maketu izveidojis Aleksejs

Muraško. Teksta salikumā izmantoti burtveidol

FF Casus Pro (Jevgeniijs Jukečevs, Berline) un

FF Scala Sans Pro (Martins Majors, Arnema).

Grāmata iespiesta un iesieta Jelgavas tipograāfijā. Papirs iekšlapām: Munken Print Cream $1590 \mathrm{~g} / \mathrm{m}^{2}$

(Arctic Paper, Zviedrija); papirs vãkam: Materica

Acqua $250 \mathrm{~g} / \mathrm{m}^{2}$ (Fedrigoni, Itālija).
Apmaldījušies briviibā: anomija mūsdienu Latvijā

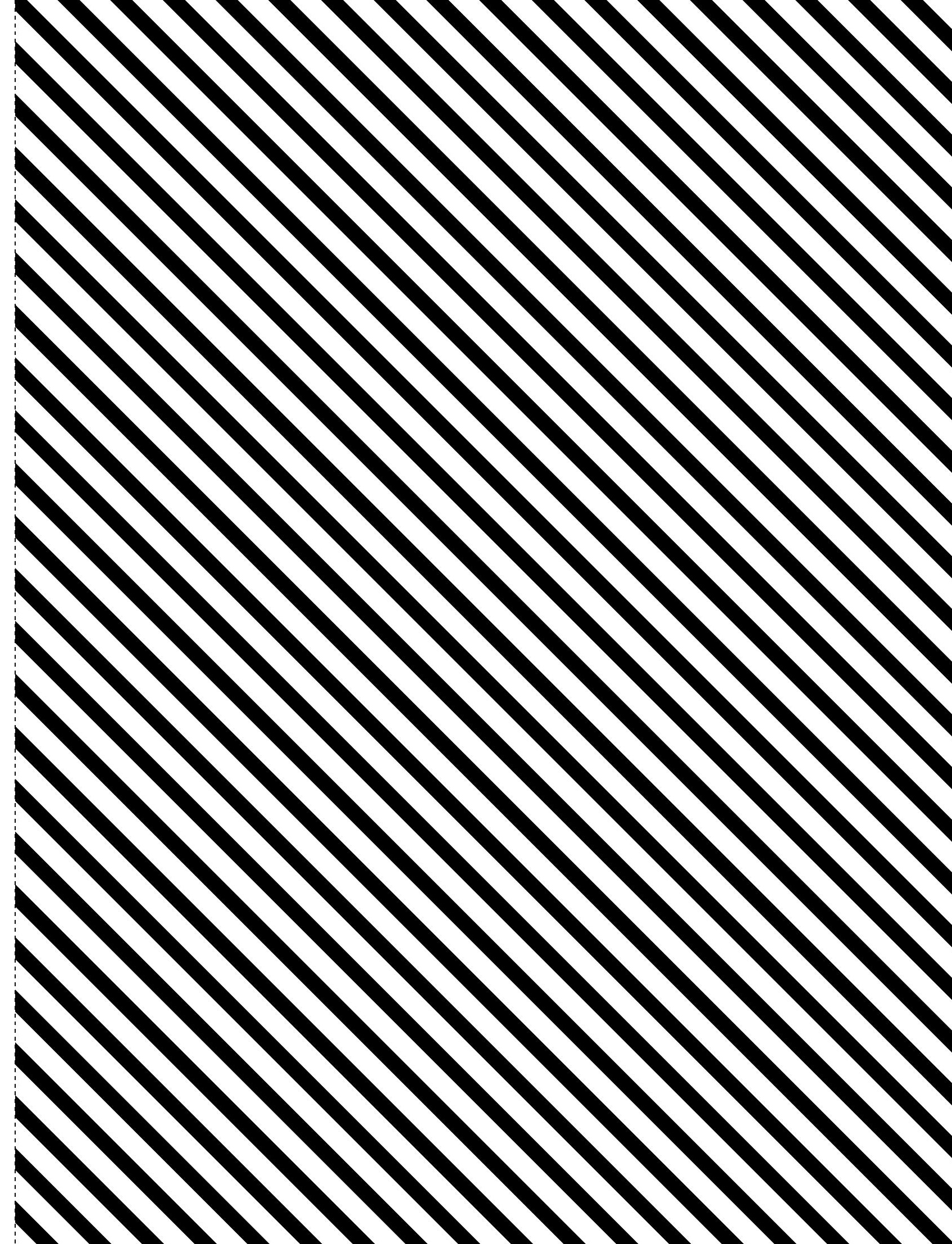


Kolektīvā monogrāfija «Apmaldījušies brīvībā: anomija mūsdienu Latvijā» apkopo valsts pētijumu programmas «Inovācija un ilgtspējiga attīstība: Latvijas pēckrīzes procesi globālā kontekstā» (SUSTINNO) ietvaros realizētā pētijumu projekta «Sabiedrības vērtīborientācijas un sabiedrības atjaunošanās» galvenās atziņas. Šis projekts tika isstenots Latvijas Universitātes Sociālo zinātṇu fakultātes Sociālo un politisko pētijumu institūtā laikā no 2014. lỉdz 2018. gadam.

Dažādu sociālo zinātṇu nozaru pētnieku darbs ir rezultējies vienotā skatijjumā uz dažādiem savstarpēji ḷoti atšḳirīgiem fenomeniem - politisko atsvešinātību, globālo vērtību orientāciju, attieksmi pret valsts drošibu, reproduktīvo uzvedību, svētku un piemiņas dienu svinēšanas praksēm Latvijas sabiedrībā-tie kolektivajā monogrāfijā aplūkoti no anomijas perspektivas. Projekta rezultāti atspoguḷoti daudzās akadēmiskās un populārās publikācijās, kas ne tikai sniedz atbildes uz pētnieku izvirzītajiem jautājumiem, bet arì rosina diskusijas par sabiedrībā aktuālām problēmām. 